\title{
Uma análise crítica de um recurso educacional aberto digital concebido para o ensino-aprendizagem da Estatística no Ensino Médio \\ Caio Cesar Santos Diniz
}

Dissertação de Mestrado

Programa de Pós-Graduação em Mestrado Profissional em Ensino de

Matemática do Instituto de Matemática e Estatística da

Universidade de São Paulo

Orientadora: Prof ${ }^{\mathrm{a}}$. Dr ${ }^{\mathrm{a}}$. Viviana Giampaoli

São Paulo, Agosto de 2016 


\section{Uma análise crítica de um recurso educacional aberto concebido para o ensino-aprendizagem da Estatística no Ensino Médio}

Esta é uma versão original e corrigida da dissertação contendo as alterações sugeridas pelos membros da Comissão Julgadora do trabalho durante a sua defesa pública realizada no dia 27 de junho de 2016 no Instituto de Matemática e Estatística da Universidade de São Paulo.

Comissão Julgadora:

Prof $^{\mathrm{a}}$. Dr ${ }^{\mathrm{a}}$. Viviana Giampaoli (Presidente) - IME-USP

Prof $^{\mathrm{a}}$. Dra ${ }^{\mathrm{a}}$. Ana Paula Jahn (Titular) - IME-USP

Prof $^{\mathrm{a}}$. Dr ${ }^{\mathrm{a}}$. Claudia Regina Oliveira de Paiva Lima (Titular) - UFPE 


\section{AGRADECIMENTOS}

A Deus, pois a sua força e presença foram essenciais para que nos bons momentos eu pudesse manter a simplicidade e a humildade e que nos momentos mais difíceis foram cruciais para que eu mantivesse a serenidade, a confiança e a certeza da minha capacidade.

À minha esposa Cátia Maringolo, pelos ensinamentos, incentivos, orientação científica e principalmente a leitura e discussão cuidadosa do texto comigo, o que muito contribui para o meu amadurecimento e por conseguinte a melhoria do texto.

À Profa. Viviana Giampaoli, pelo aceite em orientar esta pesquisa, pelos seus ensinamentos, críticas, sugestões, elogios e sobretudo pela sua seriedade, rigor e preocupação com a minha formação e a condução da pesquisa. Agradeço também pela sua confiança e a liberdade com que me permitiu trabalhar e desenvolver as minhas ideias. Suas atitudes foram capazes de extrair o melhor de mim em prol da pesquisa.

Às Profas. Ana Paula Jahn, Claudia Regina Oliveira de Paiva Lima e Lisbeth Kaiserlian Cordani cujas considerações sobre o trabalho me possibilitaram reflexões importantes para o avanço da pesquisa, aprimoramento do texto e a minha formação.

Ao Prof. Tel Amiel, pela solicitude e auxílio com a indicação de valiosas referências sobre recursos educacionais abertos.

Aos colegas e professores do curso com os quais pude discutir e principalmente aprender.

Ao meu colega Ronaldo Bezerra Nobre, sua confiança e auxílio me permitiram uma dedicação quase que exclusiva para a pesquisa. Lhe sou eternamente grato meu grande amigo.

À minha colega Ana Olívia Ramos Pires Justo, pelas diversas discussões que tivemos acerca da pesquisa e pela leitura minuciosa do texto, suas considerações foram valiosas e contribuíram em muito para a minha formação e visão sobre o texto, o que permitiu um grande salto de qualidade para o mesmo.

Ao Centro de Aperfeiçoamento do Ensino de Matemática “João Affonso Pascarelli" (CAEM) do IME-USP, pelas palestras, oficinas e minicursos os quais pude participar e que tanto contribuíram para a minha formação.

À USP, pela infraestrutura física e de recursos humanos disponibilizada, as quais me propiciaram um profundo avanço pessoal, profissional e que me permitiram deixar uma singela marca na ciência e um legado para a humanidade. 


\section{RESUMO}

DINIZ, C. C. S. Uma análise crítica de um recurso educacional aberto digital concebido para o ensino-aprendizagem da Estatística no Ensino Médio. Dissertação (Mestrado) Instituto de Matemática e Estatística, Universidade de São Paulo, São Paulo, 2016.

A evolução das tecnologias, junto com a expansão do uso da internet têm nos propiciado uma gama de ferramentas que podem ser utilizadas no ensino-aprendizagem na Educação Básica. Em particular, no contexto do ensino-aprendizagem da Estatística no Ensino Médio pode-se verificar a existência de numerosa quantidade de recursos educacionais para tal. Portanto, o problema que está colocado para o professor diz respeito à seleção criteriosa destes recursos para a sua utilização em sala de aula. Nesse sentido, por meio deste trabalho esperamos contribuir para o avanço deste tema propondo diferentes critérios de análise. O conjunto de critérios estabelecido mostrou-se consistente e adequado para a análise do recurso investigado e, podemos concluir que dependendo da qualidade do recurso e como este será utilizado pelo professor em sala de aula, ele poderá representar uma efetiva contribuição para o ensinoaprendizagem da Estatística no Ensino Médio. Por outro lado, corre-se o risco que se um recurso não é previamente analisado, ele poderá eventualmente favorecer o desenvolvimento de conceitos estatísticos incorretos, bem como agravar algumas das dificuldades que já se façam existentes na sua aprendizagem.

Palavras-chave: Ensino-aprendizagem. Ensino de Estatística. Tecnologias da Informação e Comunicação (TIC). Recursos Educacionais Abertos (REA). 


\begin{abstract}
DINIZ, C. C. S. A critical analysis of a digital open educational resource designed for the teaching-learning process of Statistics in high school. Dissertação (Mestrado) - Instituto de Matemática e Estatística, Universidade de São Paulo, São Paulo, 2016.

The evolution of technologies, along with the spread of the internet use, has provided us a wide range of tools that may be used in the teaching-learning process on basic education. Particularly, in the context of the teaching-learning process of Statistics in high school, it is possible to verify the existence of a huge number of open educational resources for that purpose. Thus, the problem that teachers have to face concerns the careful assessment of these resources for their use in the classroom. Therefore, through this dissertation, we aim to contribute to the advance of this topic proposing different criteria of analysis. The established set of criteria proved to be consistent and appropriate for the analysis of the investigated resource. We are able to conclude that depending on the quality of the resource and how it will be used by the teacher in the classroom, it may represent an effective contribution to the teaching-learning process of Statistics in high school. On the other hand, there is a risk that if a resource is not previously analyzed, it may eventually endorse wrong statistics concepts, as well as aggravate pre-existent difficulties in their learning process.
\end{abstract}

Key-words: Teaching-learning process. Teaching of Statistics. Information and Communication Technologies (ICT). Open Educational Resources (OER). 


\section{LISTA DE FIGURAS}

Figura 1 - Página inicial do repositório M3 ..................................................................61

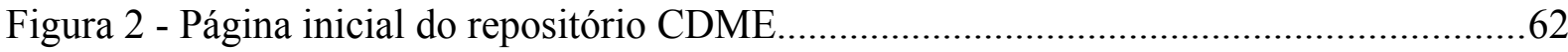

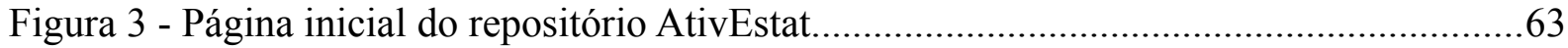

Figura 4 - Página de apresentação do recurso "Medidas do corpo: gráficos univariados".......69

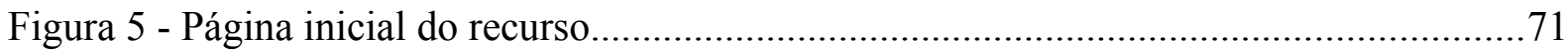

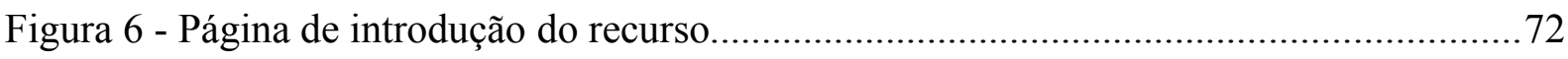

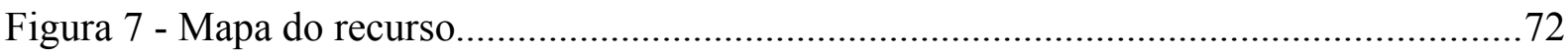

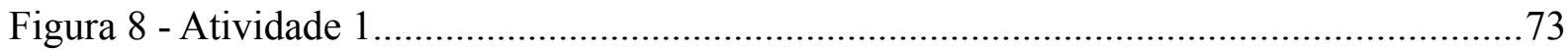

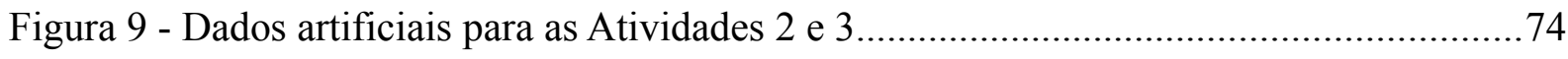

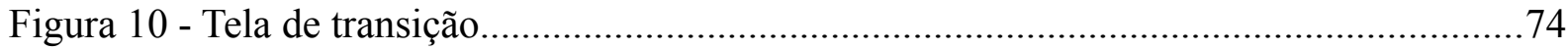

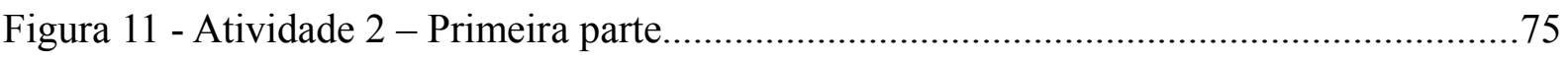

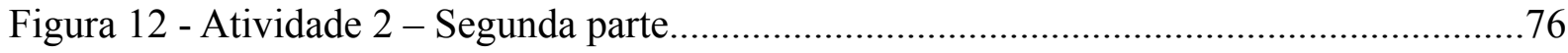

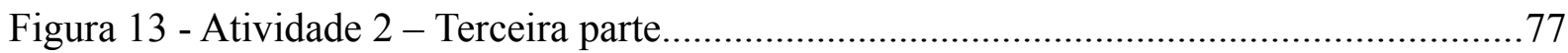

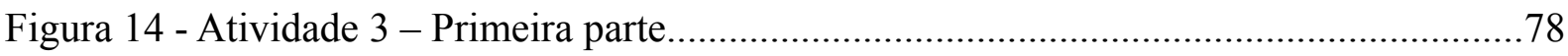

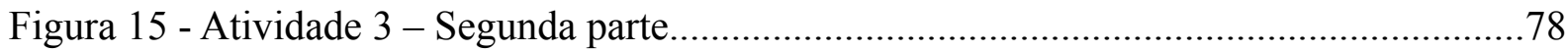

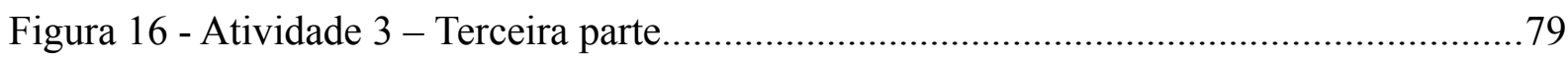

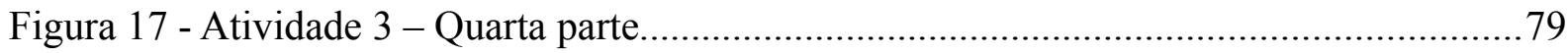

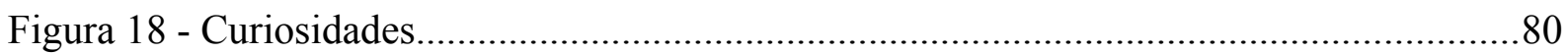

Figura 19 - Histograma da primeira parte da Atividade 3 ................................................... 86

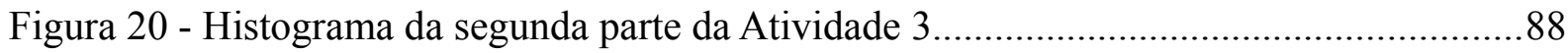

Figura 21 - Inconsistência do feedback na resposta sobre a moda.......................................89

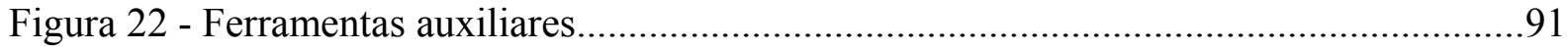

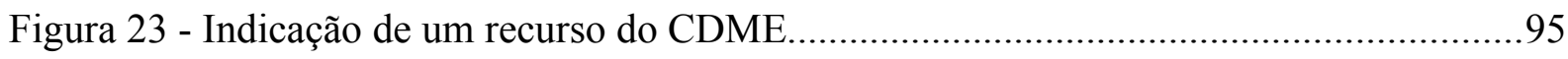

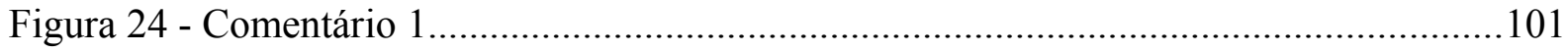

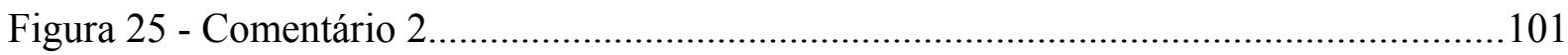

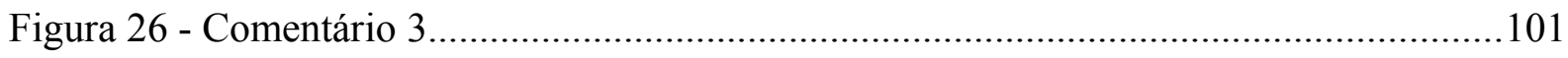




\section{LISTA DE TABELAS}

Tabela 1 - Catálogo de REA para o ensino-aprendizagem de Probabilidade e Estatística do repositório CDME.

Tabela 2 - Catálogo de REA para o ensino-aprendizagem de Probabilidade e Estatística do repositório M3.

Tabela 3 - Quantidade de recursos: tipo de recurso versus repositório.

Tabela 4 - Quantidade de recursos: tipo de recurso versus tema

Tabela 5 - Infraestrutura de TIC 123

Tabela 6 - Conteúdo 123

Tabela 7 - Linguagem e Orientações 123

Tabela 8 - Interação. 124

Tabela 9 - Navegação. 124

Tabela 10 - Aspectos gerais. 


\section{LISTA DE ABREVIATURAS E SIGLAS}

AtivEstat - Atividades de Estatística

BID - Banco Interamericano de Desenvolvimento

CAEM - Centro de Aperfeiçoamento do Ensino de Matemática "João Affonso Pascarelli"

CDME - Conteúdos Digitais para o ensino e aprendizagem de Matemática e Estatística

CEB - Câmara de Educação Básica

CGI.br - Comitê Gestor da Internet no Brasil

CNE - Conselho Nacional de Educação

$\mathrm{CP}$ - Conselho Pleno

EBRAPEM - Encontro Brasileiro dos Estudantes de Pós-Graduação em Educação

Matemática

FNDE - Fundo Nacional de Desenvolvimento da Educação

IBGE - Instituto Brasileiro de Geografia e Estatística

IME-USP - Instituto de Matemática e Estatística da Universidade de São Paulo

IMECC-UNICAMP - Instituto de Matemática, Estatística e Computação Científica da Universidade Estadual de Campinas

Libras - Língua Brasileira de Sinais

MEC - Ministério da Educação

MCT - Ministério da Ciência e Tecnologia

MIT - Instituto de Tecnologia de Massachussetts

M3 - Coleção Matemática Multimídia

$\mathrm{PCN}+$ Ensino Médio - Orientações Educacionais Complementares aos Parâmetros Curriculares Nacionais/Ciências da Natureza, Matemática e suas Tecnologias

PCNEM - Parâmetros Curriculares Nacionais do Ensino Médio

PNLD - Programa Nacional do Livro Didático

PRCEU - Pró-Reitoria de Cultura e Extensão Universitária

PRG - Pró-Reitoria de Graduação

REA - Recursos Educacionais Abertos

TDIC - Tecnologias Digitais da Informação e Comunicação

TIC - Tecnologias da Informação e Comunicação

UFF - Universidade Federal Fluminense

UFJF - Universidade Federal de Juiz de Fora

UNESCO - Organização das Nações Unidas para a Educação, a Ciência e a Cultura

UNESP - Universidade Estadual Paulista "Júlio de Mesquita Filho"

UNICAMP - Universidade Estadual de Campinas

USP - Universidade de São Paulo 


\section{SUMÁRIO}

1 Introdução.

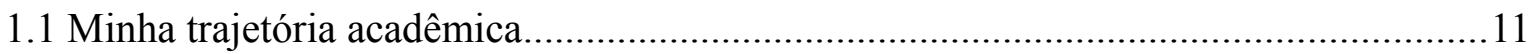

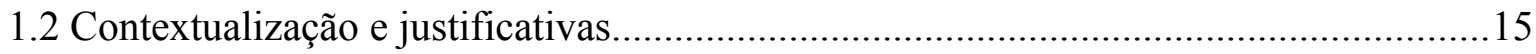

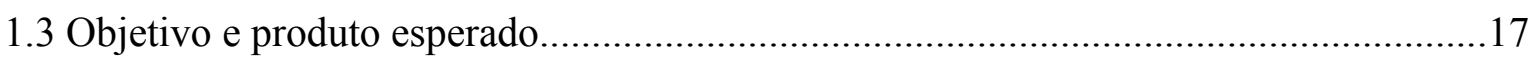

1.4 Natureza da pesquisa, abordagem e metodologia de trabalho......................................19

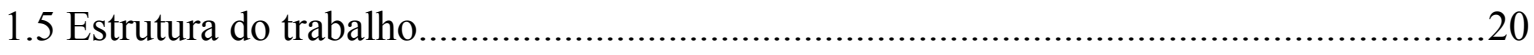

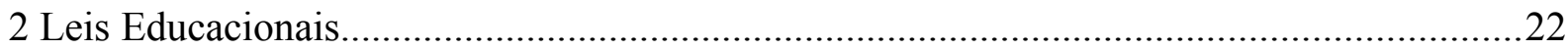

2.1 O ensino-aprendizagem da Matemática no Ensino Médio...........................................22

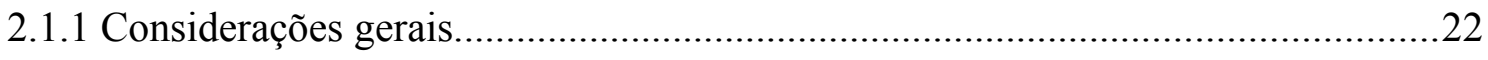

2.1.2 O ensino-aprendizagem da Estatística no Ensino Médio........................................23

2.2 A utilização de tecnologias no ensino-aprendizagem na Educação Básica....................25

3 Tecnologias da Informação e Comunicação (TIC) na Educação.........................................27

3.1 As TIC e algumas das justificativas para a sua utilização na Educação.........................28

3.1.1 Em busca de uma delimitação das TIC...............................................................28

3.1.2 Duas justificativas para o uso das TIC na Educação..........................................29

3.2 Algumas abordagens no uso dos computadores na Educação.......................................32

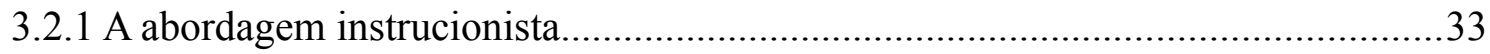

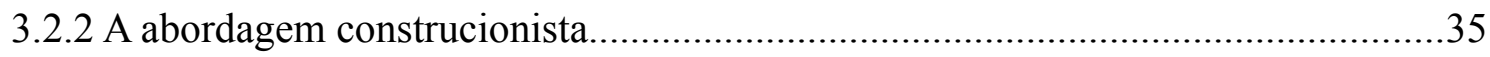

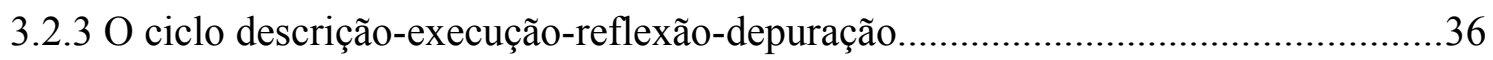

3.2.4 Existe alguma abordagem que pode ser considerada como "mais apropriada" no

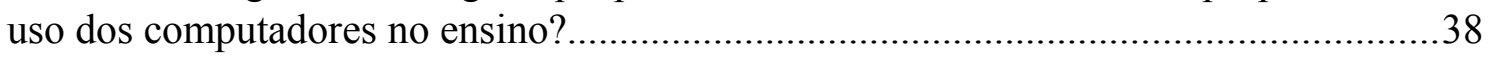

3.3 Um breve panorama do acesso e utilização das TIC nas escolas brasileiras...................39

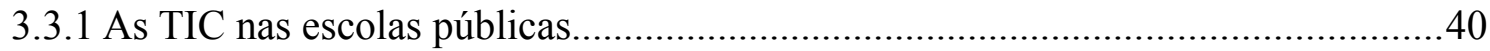

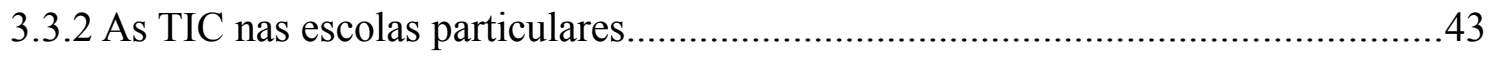

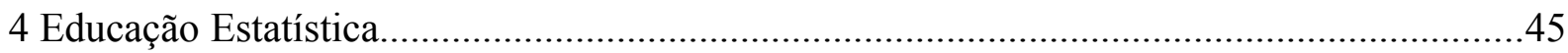

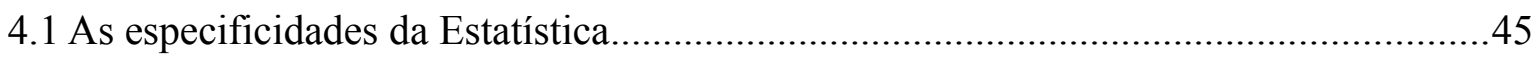

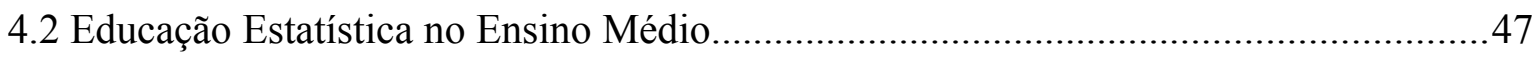

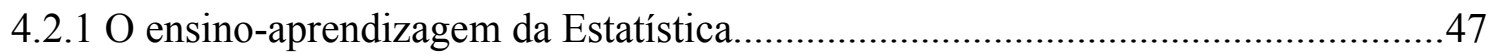

4.2.2 As dificuldades na aprendizagem da Estatística................................................51

4.3 A utilização das Tecnologias de Informação e Comunicação (TIC) no ensino-aprendizagem da Estatística no Ensino Médio...................................................................56 
4.3.1 Uma primeira ideia de utilização das TIC no ensino-aprendizagem da Estatística no Ensino Médio: o caso das planilhas eletrônicas.

4.3.2 Uma segunda ideia de utilização das TIC no ensino-aprendizagem da Estatística no Ensino Médio: o caso dos recursos educacionais disponíveis na internet. .58

5 Critérios e a análise crítica de um Recurso Educacional Aberto (REA).

5.1 Repositórios de recursos educacionais digitais para o ensino-aprendizagem de Probabilidade e Estatística.

5.1.1 Coleção Matemática Multimídia (M3).

5.1.2 Conteúdos digitais para o ensino e aprendizagem de Matemática e Estatística (CDME)......

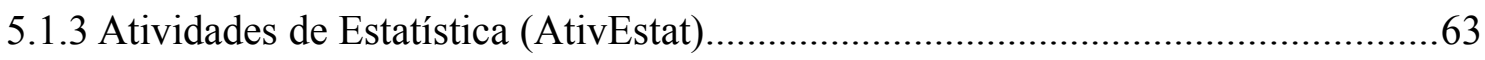

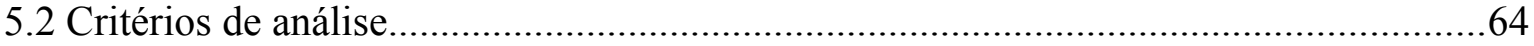

5.3 O recurso "Medidas do corpo: gráficos univariados" e sua análise crítica....................67

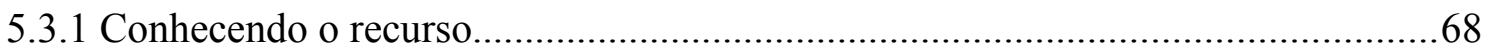

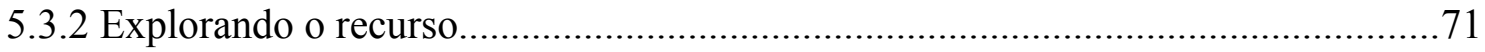

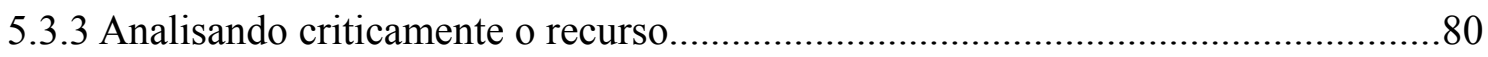

5.3.3.1 Guia didático, Usabilidade e Estabilidade (C1, C2 e C3)...............................81

5.3.3.2 Consistência do conteúdo (C4)......

5.3.3.3 Perspectiva epistemológica, Ferramentas de acessibilidade, Potencial didático, Manipulação de dados e representações, Contribuição à cidadania, Conexão com outros recursos e Licença de uso, abertura e formato técnico (C5 a C11).....

6 Uma experiência na utilização e avaliação do recurso "Medidas do corpo: gráficos univariados" em uma oficina para professores de Matemática...............................................97

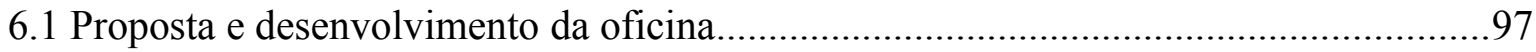

$6.2 \mathrm{O}$ questionário de avaliação e os resultados da avaliação dos participantes..................98

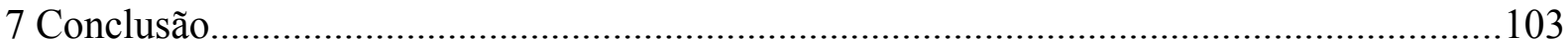

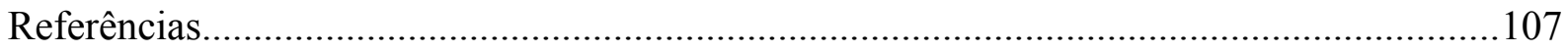

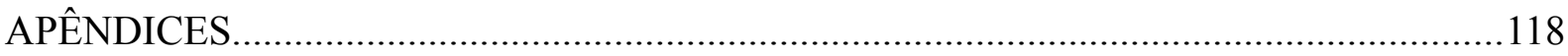

APÊNDICE A - Catálogo de Recursos Educacionais Abertos (REA) para o ensino-aprendizagem da Probabilidade e Estatística no Ensino Médio alocados nos repositórios Conteúdos Digitais para o ensino e aprendizagem de Matemática e Estatística (CDME) e Coleção Matemática Multimídia (M3) ..............................................................................119

APÊNDICE B - Resultado das avaliações dos participantes...........................................123

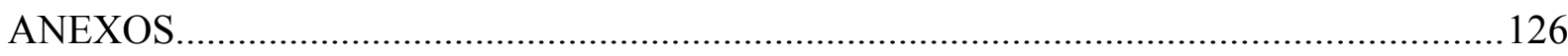

ANEXO I - Questionário de avaliação. 
ANEXO II - Respostas dos participantes e Termo de Consentimento Livre e Esclarecido 


\section{Introdução}

\subsection{Minha trajetória acadêmica}

Nossas vidas são regidas em grande parte pelas leis do acaso. Ao mesmo tempo que isso possa nos causar um desconforto, por outro lado, pode ser considerado como um dos aspectos que as torna interessantes e desafiadoras. Nada sabemos a respeito das pessoas que encontraremos daqui a cinco anos ou em quais projetos estaremos engajados em um futuro não muito distante.

Ao realizarmos um breve retrospecto de nossa trajetória acadêmica, podemos elucidar um pouco o papel do acaso em nossa vida. Podemos verificar o aspecto não determinístico inerente a tal percurso, em que cada decisão tomada por nós é, em grande parte, fruto de uma série de eventos inesperados. De fato, uma parcela pequena de nossa vida está realmente sob o nosso controle.

Isto posto, nesta seção, apresentarei alguns dos eventos decisivos e inesperados que ocorreram ao longo da minha breve trajetória acadêmica, farei isso, com o intuito de oferecer-lhes algumas das minhas justificativas pessoais para a realização deste trabalho.

Minha trajetória no Ensino da Matemática iniciou-se no ano de 2008, quando ingressei no curso de Licenciatura em Matemática da Universidade Estadual Paulista "Júlio de Mesquita Filho” (UNESP) na cidade de São José do Rio Preto.

Já no meu primeiro ano de graduação, participei como voluntário em um projeto de extensão voltado para a utilização de jogos no ensino da Matemática na Educação Básica. Tais atividades foram decisivas para o fortalecimento das minhas ideias iniciais de me tornar um professor, pois o contato com os estudantes nas escolas, as experiências com meus colegas de projeto e o desenvolvimento de atividades de ensino-aprendizagem diferentes daquelas tradicionalmente realizadas em sala de aula me despertaram um desejo pelo novo.

No segundo ano do curso continuei como voluntário no projeto de jogos. Neste ano, de maneira inesperada, surgiu a possibilidade de lecionar a disciplina de Trigonometria em um curso pré-vestibular vinculado à universidade. Entendi que tal desafio seria relevante e fundamental para minha formação como professor e pode-se dizer que a partir do ano 2009 adentrei de fato na sala de aula. Entretanto, assim como no primeiro ano de curso, nenhum 
contato tive com as Tecnologias da Informação e Comunicação (TIC) ou com ensino-aprendizagem de Probabilidade e Estatística.

Já em 2010 continuei atuando como voluntário no projeto de jogos e como professor no curso pré-vestibular, no entanto, lecionando agora a disciplina de Geometria Analítica. Neste ano, iniciei o estágio de observação nas escolas.

Além disso, também tive contato com colegas que participavam de outro projeto de extensão, porém, na linha de Informática no Ensino Matemática, com o uso principalmente do software Geogebra e jogos de computador.

Pode-se dizer que tal contato foi decisivo, pois mesmo não participando efetivamente do projeto, tive acesso às produções e relatos destes colegas e, as possibilidades de ensino-aprendizagem oferecidas através de tal abordagem mostravam-se bastante animadoras a meu ver, principalmente no que se refere à participação e empenho dos estudantes nas atividades.

Ainda neste mesmo ano, cursei a disciplina de Introdução à Probabilidade e pode-se dizer que este foi o meu primeiro contato efetivo com o tema. Apesar das dificuldades intrínsecas ao conteúdo, bem como aquelas que naturalmente ocorrem no seu ensino-aprendizagem, os temas estudados me pareciam belos e interessantes.

Confesso que em momento algum anterior ao ingresso na universidade eu teria imaginado a possibilidade de estudar a Matemática com tal nível de rigor, muito menos poderia ter em mente que, por exemplo, o Cálculo Diferencial e Integral estaria tão presente no estudo da Probabilidade. Aquilo me impressionou.

No ano de 2011, último ano de graduação, iniciei o estágio de regência, onde pude vivenciar brevemente algumas das atribuições inerentes ao cargo de professor, tais como, participar de reuniões pedagógicas e, preparar e ministrar aulas.

Neste mesmo ano de 2011, também continuei como professor no curso pré-vestibular, entretanto, lecionando agora a disciplina de Álgebra. Devido aos diversos compromissos inerentes a um último ano de graduação, infelizmente não pude continuar no projeto de jogos no ensino da Matemática na Educação Básica. Uma das minhas expectativas para este ano era a de cursar as disciplinas de Informática no Ensino da Matemática e História da Matemática, entretanto, isso não veio a se concretizar, pois tais disciplinas são optativas e naquele ano não foram oferecidas.

Em minha visão, tal fato constituiu uma lacuna na minha formação inicial, mas que por outro lado, representava uma possibilidade de estudos para a minha formação continuada. 
Ainda em 2011, cursei a disciplina de Estatística Básica e tal como acontecera com a Probabilidade, este foi o primeiro contato efetivo que tive com o tema. As ideias e métodos estatísticos me despertaram curiosidade e interesse, sobretudo, os Testes de Hipótese.

O único contato com a tecnologia no ensino-aprendizagem dessa disciplina ocorreu tão somente nas últimas aulas do curso, onde utilizamos um software do tipo "pacote estatístico" para realizar alguns cálculos de medidas de posição e dispersão, bem como para a realização de alguns Testes de Hipótese.

Após a conclusão do curso, já no ano de 2012, ingressei como professor em uma escola particular da cidade de São Paulo, onde lecionei para turmas do Ensino Médio. Ainda que eu já tivesse alguma experiência com o ensino-aprendizagem da Probabilidade e Estatística através de aulas particulares que lecionei, esta foi a primeira vez onde pude vivenciar as dificuldades do seu ensino-aprendizagem em uma situação de sala de aula.

Com o objetivo de me apropriar das TIC como uma ferramenta de ensino, passei a realizar algumas experiências com os estudantes recomendando-lhes vídeos e alguns outros recursos disponíveis na internet. Neste momento, pude avançar um pouco no que se refere a uma compreensão das TIC na Educação.

Porém, descobri que meus conhecimentos sobre o assunto eram limitados e que eu possuía diversas indagações sobre o tema, tais como: por que, como, onde e quando utilizar as TIC? Existem outras formas de se utilizar as TIC além de encaminhar os estudantes a utilizar recursos já existentes na internet? O software Geogebra serve tão somente para a construção de gráficos de funções? As planilhas eletrônicas servem apenas para realizar cálculos de medidas de posição e dispersão, ou seja, simplesmente para suprimir um trabalho que seria realizado manualmente? Acredito que tal momento foi um dos precursores para a minha investida no estudo das TIC na Educação.

No mês de agosto de 2013, ingressei no Mestrado Profissional com o intuito de adquirir e aperfeiçoar meus conhecimentos, bem como avançar em busca de novos conhecimentos, os quais motivados principalmente pela minha breve experiência em sala de aula e algumas das dificuldades que deparei em tal ambiente.

A princípio, eu tinha em mente realizar pesquisa sobre algo que envolvesse História da Matemática e Logaritmos, entretanto, a coordenação do programa me designou como orientadora a Profa. Viviana Giampaoli, docente do Departamento de Estatística. Ela me propôs trabalhar com o ensino-aprendizagem de Probabilidade e Estatística, pois esta era a linha de pesquisa na qual ela poderia me orientar. 
Ainda que tal proposta tenha sido diferente daquela que eu tinha em mente, refleti e compreendi que isto poderia ser um grande desafio e uma oportunidade de compreender melhor a Probabilidade e Estatística, temas que já tinham me fascinado na graduação.

Desse modo, tendo estabelecido que minha pesquisa seria vinculada ao ensino-aprendizagem de Probabilidade e Estatística, iniciei algumas leituras para adquirir uma visão panorâmica sobre o tema e também para determinar o problema de pesquisa.

Além disso, no início de 2014 passei a frequentar os Seminários de Educação Estatística, organizados pelo Prof. Marcos Nascimento Magalhães, o que contribuiu efetivamente para a minha inserção na Educação Estatística. No decorrer das disciplinas do mestrado, estabeleci que iria trabalhar com as TIC no ensino-aprendizagem de Probabilidade e Estatística, no que obtive aval e apoio da Profa. Viviana Giampaoli.

Porém, mesmo delimitando um campo de trabalho, este ainda mostrava-se relativamente amplo para o estabelecimento conciso de um problema de pesquisa. Eu carecia de um pouco mais de detalhes e experiência.

Eis então que no segundo semestre de 2014 ocorreu um fato decisivo para que eu pudesse finalmente estabelecer o problema de pesquisa e daí então estudá-lo, pois neste período tive a possibilidade de cursar a disciplina MPM5603 - Tecnologias de Informática no Ensino de Matemática - ministrada pelas Profas. Maria Cristina Bonomi e Ana Paula Jahn.

Uma das atividades realizadas no decorrer do curso foi exatamente a de se realizar uma análise crítica de recursos voltados para o ensino-aprendizagem da Matemática e pode-se dizer que fundamentalmente, a partir destas atividades, é que as ideias para a realização deste trabalho foram originadas, da convergência entre as TIC, a Educação Estatística e a análise crítica de recursos.

Em suma, conhecendo algumas das possibilidades de ensino-aprendizagem propiciados pelas TIC, concebendo-se também a existência de um problema crônico de aversão à Matemática por parte dos estudantes, bem como as dificuldades no seu ensino-aprendizagem, é que entendemos e vislumbramos nas TIC uma possibilidade de superação desse quadro. 


\subsection{Contextualização e justificativas}

$\mathrm{O}$ rápido avanço das tecnologias e principalmente da internet a partir do início do século XXI possibilitaram a produção e difusão de um amplo leque de recursos para o ensino-aprendizagem, desde a Educação Infantil até o Ensino Superior.

Hoje temos acesso a videoaulas, textos, software dentre outros recursos das mais diversas disciplinas e em muitos dos casos, disponíveis na internet de forma gratuita. Podemos assistir a uma aula de Matemática, por exemplo, que foi ministrada na Austrália ou nos Estados Unidos. Além disso, tais recursos vêm aumentando em um ritmo acelerado e acompanhar cada novidade é uma tarefa praticamente impossível.

No contexto educacional, pode-se até dizer que vivemos em uma era em que há uma abundância de recursos educacionais e isto vale também para o caso dos conteúdos de Probabilidade e Estatística.

Assim, o problema que se coloca é sobre o que já conhecemos e o que devemos conhecer sobre tais recursos para que possamos, de fato, potencializar a aprendizagem dos estudantes através de tais ferramentas.

Uma das justificativas para a utilização de tecnologias na Educação encontra-se, por exemplo, no Plano Nacional de Educação ${ }^{1}$ (BRASIL, 2014c), que frisa, mais especificamente, o uso de recursos educacionais abertos com o objetivo de possibilitar novas formas de ensino-aprendizagem e que porventura poderão contribuir para a melhoria da Educação Básica. A seguir descrevemos uma das metas relacionadas a este tema.

Meta 7: fomentar a qualidade da educação básica em todas as etapas e modalidades, com melhoria do fluxo escolar e da aprendizagem [...] Estratégia 7.12: incentivar o desenvolvimento, selecionar, certificar e divulgar tecnologias educacionais para a educação infantil, o ensino fundamental e o ensino médio e incentivar práticas pedagógicas inovadoras que assegurem a melhoria do fluxo escolar e a aprendizagem, assegurada a diversidade de métodos e propostas pedagógicas, com preferência para softwares livres e recursos educacionais abertos, bem como o acompanhamento dos resultados nos sistemas de ensino em que forem aplicadas. (BRASIL, 2014c)

\footnotetext{
${ }^{1}$ O Plano Nacional de Educação está em vigor desde o dia 25 de junho de 2014 e tem duração de 10 anos, ou seja, as metas expressas no referido documento deverão ser atingidas até o ano de 2024.
} 
Assim, acreditamos que por meio da análise crítica de um recurso educacional aberto digital concebido para o ensino-aprendizagem da Estatística e Probabilidade, esperamos contribuir para a consecução da meta descrita.

Conforme já destacado, é fato a existência de um grande número de software educacionais e recursos disponíveis na internet com o intuito de propiciar novas experiências de ensino-aprendizagem, em particular, no caso da Estatística ${ }^{2}$.

Ainda que, por um lado, tal variedade possa vir a ser considerada como algo positivo, por outro lado, ela se configura como desafio, sobretudo para o professor, pois em meio a tantas possibilidades, selecionar e avaliar os recursos disponíveis para a sua utilização em sala de aula torna-se fundamental.

Nesse sentido, nosso trabalho pretende auxiliar o professor na tarefa de avaliar e selecionar recursos educacionais digitais para a utilização com os estudantes. Tal avaliação e seleção, aliás, está destacada no documento Padrões de Competência em Tecnologias da Informação e Comunicação (TIC) para Professores da Educação Básica da Organização das Nações Unidas para a Educação, Ciência e Cultura (UNESCO), onde consta:

Os professores deverão ser capazes de: [...] Localizar plataformas, pacotes de softwares educacionais e recursos da Web, bem como avaliá-los para que eles sejam utilizados com precisão e de modo alinhado aos padrões curriculares, além de adequá-los para as necessidades de estudantes específicos ${ }^{3}$. (UNESCO, 2008, p.10, tradução nossa)

Iremos agora evidenciar uma última justificativa para a realização desta pesquisa, identificada no campo da Educação Estatística, que por sua vez reflete algumas das preocupações colocadas pela comunidade científica de educadores estatísticos em relação a um avanço no entendimento da questão da utilização das TIC nos processos de ensino-aprendizagem. No artigo em que discutem a respeito do papel da tecnologia na melhoria da aprendizagem da Estatística, Chance et al. (2007) destacam que:

\footnotetext{
${ }^{2}$ Ver por exemplo Tishkovskaya e Lancaster (2012) e o catálogo de recursos apresentado no Apêndice A.

3 "Teachers should be able to: [...] Locate off-the-shelf educational softwares packages and Web resources and evaluate them for their accuracy and alignment with curriculum standards and match them to the needs for specific students".
} 
Embora existam pesquisas que possam sustentar a utilização das tecnologias para facilitar e aprimorar a aprendizagem dos conceitos estatísticos, Biehler (1997) alerta que os educadores estatísticos necessitam de métodos para avaliar criticamente os softwares existentes tanto do ponto de vista de como eles serão utilizados para educar os estudantes, bem como para a produção futura de softwares mais adequados tanto para a aprendizagem como para a prática de pesquisas estatísticas em cursos introdutórios ${ }^{4}$. (CHANCE et al., 2007, p.15, tradução nossa)

Assim, a preocupação de uma análise crítica de recursos concebidos para o ensino-aprendizagem da Estatística também se faz presente na comunidade da Educação Estatística, pois é preciso investigar sobre a utilização dos software já existentes, sobretudo porque tais pesquisas poderão contribuir para a melhoria na construção de novos recursos ou no aprimoramento daqueles já existentes.

\subsection{Objetivo e produto esperado}

O nosso objetivo para este trabalho de pesquisa é estabelecer critérios para a análise de recursos educacionais abertos digitais concebidos para o ensino-aprendizagem da Probabilidade e Estatística no Ensino Médio. Nesse sentido, discutiremos e ilustraremos a utilização de tais critérios por meio da análise de um determinado recurso à luz destes critérios.

De início, no que se refere ao termo Recursos Educacionais Abertos (REA), adotamos a definição apresentada por Santos $(2013$, p.21) e criada inicialmente pela UNESCO durante o "Forum on the impact of Open CourseWare for Higher Education in Developing Countries" realizado no Instituto de Tecnologia de Massachussetts (MIT) no ano de 2002. Desse modo, recursos educacionais abertos são "recursos de ensino, aprendizagem e pesquisa que estejam em domínio público ou que tenham sido disponibilizados com uma licença de propriedade intelectual que permita seu uso e adaptação por terceiros".

\footnotetext{
4 "Although research supports the use of technology to facilitate and improve the learning of statistical concepts, Biehler (1997) cautions that statistics educators need a system to critically evaluate existing software from the perspective of educating students and to produce future software more adequate both for learning and doing statistics in introductory courses".
} 
Optamos pela escolha dos REA ao invés dos objetos de aprendizagem ${ }^{5}$ ou dos objetos educacionais $^{6}$, pois em nossa visão os REA podem ser considerados como uma "evolução" destes dois últimos, levando-se em conta um aspecto que consideramos fundamental: a licença de uso.

Afirmamos isto, pois os REA estão submetidos a uma licença de uso "aberta". Essa abertura consiste no fato de que o autor da obra poderá decidir sobre o que será permitido ou não ao usuário realizar com a sua obra, o que não ocorre com uma licença do tipo copyright ${ }^{7}$.

Geralmente a licença de uso de um REA permite ao usuário cinco liberdades fundamentais: retenção da obra, utilização e reutilização da obra, revisão da obra, remix e adaptação com outras obras e, redistribuição da obra.

Ainda sobre os REA, em sua definição estão contemplados recursos que estão em formato digital ou não, porém, neste trabalho optamos apenas pelo estudo de um REA que está disponibilizado em formato digital, pois acreditamos que as cinco liberdades fundamentais podem ser vivenciadas de uma forma mais efetiva pelo usuário, caso o recurso esteja disponibilizado nesse tipo de formato.

Além disso, os materiais disponibilizados em formato digital podem potencialmente ampliar o acesso ao conhecimento, bem como possibilitar que diversas produções intelectuais se tornem bens não rivais, conforme ressaltam Bonilla e Pretto, ponderando que esse tipo de formato,

[...] tem trazido para a sociedade uma possibilidade ímpar de ampliar o conhecimento, fazendo-o circular no modelo todos para todos, sem a necessidade de intermediários. As produções passam a ser não rivais, no sentido de que seu consumo por um não anula a possibilidade de o mesmo produto - ou sua cópia - ser consumido por muitos". (BONILLA; PRETTO, 2015, p.28)

Anteriormente à análise do recurso, faz-se necessário o estabelecimento de critérios norteadores para a referida análise. Acrescentamos também que, nossa intenção aqui não é a

\footnotetext{
${ }^{5}$ Para Wiley (2001, p.4), objeto de aprendizagem é "qualquer entidade digital ou não, que possa ser utilizada, reutilizada ou servir como referência para o processo de aprendizagem suportado pela tecnologia".

${ }^{6}$ No Guia do Programa Nacional do Livro Didático (PNLD) 2016 (BRASIL, 2015, p.60), objetos educacionais digitais ou simplesmente objetos digitais são "vídeos, imagens, áudios, textos, gráficos, jogos educacionais, infográficos, etc.".

7 Uma licença copyright é uma licença do tipo "todos os direitos reservados". Entretanto, um dos caminhos possíveis para o autor "abrir" legalmente sua obra, pode ser através da adoção de uma licença do tipo Creative Commons. Porém, esta licença não se aplica a todo tipo de obra. Maiores detalhes podem ser encontrados em: $<$ https://creativecommons.org/>.
} 
de apresentar uma lista exaustiva de critérios, mas sim algo que seja flexível e que possa ser modificado, adaptado e complementado pelo professor conforme o seu entendimento e, portanto, entendemos que tais critérios estejam assim alinhados com a própria ideia de REA.

Assim, esperamos contribuir com o professor de Matemática em sua tarefa de seleção e análise de recursos educacionais digitais (abertos ou não) para o ensino-aprendizagem de Estatística e Probabilidade no Ensino Médio, por meio dos critérios de análise que utilizaremos neste trabalho.

\subsection{Natureza da pesquisa, abordagem e metodologia de trabalho}

Considerando o objetivo que estabelecemos para esta pesquisa, mencionado no início da seção 1.3, podemos caracterizar nossa pesquisa, como sendo de natureza exploratória, segundo Severino (2007, p.123).

Já no que se refere ao tipo de abordagem que consideraremos para o nosso estudo, optamos por uma abordagem do tipo qualitativa, partindo-se da determinação de critérios de análise. Tal postura justifica-se pois nossa pretensão ao analisar o REA por meio de critérios é a de elucidar suas potencialidades e limitações, através da descrição das suas características que mostram-se passíveis de serem investigadas à luz dos critérios estabelecidos.

Desse modo, não é nossa intenção estabelecer uma escala de modo a quantificar ou conceituar o recurso em relação a cada critério e ao utilizarmos a palavra análise em nosso trabalho nos reportamos a sua definição em Holanda (2000, p.41), onde encontra-se que análise é o "1. Exame de cada parte de um todo para conhecer-lhe a natureza, as funções, etc. [...]". Isto é, pretendemos investigar e descrever cada parte de um todo e não mensurá-las através de alguma escala previamente estabelecida.

Portanto, considerando o objetivo estabelecido para a pesquisa, bem como a abordagem que optamos, definimos então a seguinte trajetória de trabalho:

i) em um primeiro momento desenvolveremos estudos de cunho bibliográfico com base nas leis educacionais, bem como nos trabalhos que tratam das TIC na Educação e de Educação Estatística;

ii) em um segundo momento, com base nas conclusões das pesquisas bibliográficas e da determinação de critérios de análise de REA, desenvolveremos uma análise crítica de um REA digital concebido para o ensino-aprendizagem da Estatística no Ensino Médio. 
Posteriormente, discutimos também acerca dos resultados da avaliação deste mesmo recurso realizada em uma oficina para professores de Matemática;

iii) no terceiro momento, apresentamos nossas conclusões.

\subsection{Estrutura do trabalho}

Como ponto de partida do nosso trabalho, apresentamos e discutimos no Capítulo 2 algumas das recomendações e prescrições contidas nas leis educacionais que dizem respeito ao ensino-aprendizagem da Matemática na Educação Básica, em particular, no Ensino Médio. Entretanto, iremos nos deter somente sobre os conteúdos de Estatística e Probabilidade. Pretendemos ainda neste mesmo capítulo, abordar o tema da utilização das TIC na Educação, também à luz de tais leis educacionais.

No Capítulo 3 apresentamos uma definição de TIC, bem como justificativas para a sua utilização nos processos de ensino-aprendizagem na escola básica, por meio dos elementos apresentados por Lévy (1999) e Valente (1998). Em seguida, discutimos duas abordagens na utilização das TIC na Educação.

No fechamento deste capítulo, procuramos discutir sobre a realidade das escolas brasileiras com o intuito de elucidar algumas das dificuldades que se apresentam em relação ao uso das TIC.

No Capítulo 4 iniciamos nossas considerações relatando algumas das especificidades da Estatística em relação à Matemática. $\mathrm{Na}$ sequência, apresentamos e discutimos os conteúdos da Estatística que são sugeridos a serem abordados no Ensino Médio segundo os PCN+ Ensino Médio (BRASIL, 2002a), bem como o seu ensino-aprendizagem e algumas das suas dificuldades. Já no fechamento deste capítulo, refletimos sobre algumas possibilidades de utilização das TIC no ensino-aprendizagem da Estatística e Probabilidade no Ensino Médio.

No Capítulo 5 iniciamos com uma breve apresentação de três repositórios de recursos educacionais digitais para o ensino-aprendizagem da Estatística e Probabilidade no Ensino Médio. Na sequência, definimos os critérios de análise.

Ainda neste capítulo descrevemos e analisamos criticamente o REA "Medidas do corpo: gráficos univariados"8, que encontra-se disponibilizado no repositório Coleção Matemática Multimídia (M3) da Universidade Estadual de Campinas (UNICAMP).

\footnotetext{
${ }^{8}$ Disponível em: $<\mathrm{http}: / / \mathrm{m} 3$. ime.unicamp.br/recursos/1233>. Acesso em: 18 jan. 2016.
} 
No Capítulo 6 relatamos os resultados de uma experiência na utilização e avaliação do recurso "Medidas do corpo: gráficos univariados" em uma oficina para professores de Matemática realizada junto ao Centro de Aperfeiçoamento do Ensino de Matemática "João Affonso Pascarelli” (CAEM).

No Capítulo 7 apresentamos as conclusões da pesquisa. 


\section{Leis Educacionais}

As discussões sobre as finalidades do ensino-aprendizagem dos conteúdos de Matemática na Educação Básica e em particular no Ensino Médio, costumam ser intensas e são capazes de mobilizar as atenções da sociedade de um modo geral. Isso se deve principalmente ao fato de que a Educação Básica (Educação Infantil, Ensino Fundamental e Ensino Médio) em nosso país é uma política de Estado, conforme está na Lei no 12.796 de 2013 (BRASIL, 2013a) ${ }^{9}$. Além disso, parece existir um consenso na sociedade como um todo de que o ensino-aprendizagem da Matemática na escola básica é essencial.

Assim, para que possamos contribuir para a melhoria do ensino-aprendizagem da Matemática no Ensino Médio, entendemos ser necessário um maior esclarecimento sobre suas finalidades. Nesse sentido, iremos em busca das recomendações contidas nas leis educacionais.

Estas recomendações poderão nos propiciar uma visão do assunto apoiada em leis que regulamentam o ensino em nosso país. Em virtude dos propósitos do nosso trabalho, iremos nos deter mais especificamente nos conteúdos de Estatística e na utilização de Tecnologias da Informação e Comunicação (TIC) na Educação.

\subsection{O ensino-aprendizagem da Matemática no Ensino Médio}

\subsubsection{Considerações gerais}

Para iniciarmos nossas reflexões acerca das finalidades do ensino-aprendizagem da Matemática no Ensino Médio apresentadas nas leis educacionais, destacamos o seguinte trecho da Parte III dos Parâmetros Curriculares Nacionais do Ensino Médio (PCNEM):

A Matemática no Ensino Médio tem um valor formativo, que ajuda a estruturar o pensamento e o raciocínio dedutivo, porém também desempenha um papel instrumental, pois é uma ferramenta que serve para a vida cotidiana e para muitas tarefas específicas em quase todas as atividades humanas. (BRASIL, 2000b, p. 40)

\footnotetext{
${ }^{9}$ Altera a Lei no 9.394, de 20 de dezembro de 1996, que estabelece as diretrizes e bases da educação nacional, para dispor sobre a formação dos profissionais da educação e dar outras providências.
} 
Desse modo, podemos constatar que segundo o documento, o ensino-aprendizagem da Matemática no Ensino Médio possui dupla finalidade. Ele pode assim ser considerado um fim, quando os conceitos, definições e relações são assumidos como objetos de estudo. Nesse sentido, as atividades de aprendizagem aproximam o trabalho do estudante de alguma maneira aquilo que é realizado por um matemático.

Considerando-se o ensino-aprendizagem da Matemática como um fim, entendemos que ele nos auxilia a estruturar o pensamento devido principalmente à estruturação lógica da qual ela faz uso, o rigor que lhe é pertinente, bem como a forma particular com que são validados os seus conhecimentos via demonstrações.

Por outro lado, é também um meio, pois a Matemática escolar deverá propiciar aos estudantes ferramentas para que eles possam interpretar e atuar de forma mais sistemática na sua realidade. Nessa ótica, as atividades de aprendizagem mostram-se voltadas para a identificação e aplicação da Matemática em contextos reais ou próximos destes, ou seja, os entes matemáticos são vistos como ferramentas que possibilitam a resolução de problemas vinculados à realidade do estudante.

Enquanto meio, entendemos que a aquisição dos conceitos matemáticos é fundamental para que o estudante consiga interagir e intervir em sua realidade, bem como interpretá-la adequadamente. Além do que, alguns dos conteúdos da Matemática que são estudados por ele também se fazem presentes em outras disciplinas, tais como, a Física, a Química, a Biologia e a Geografia.

\subsubsection{O ensino-aprendizagem da Estatística no Ensino Médio}

Em diversos documentos oficiais podemos verificar menções sobre a importância e as finalidades do ensino-aprendizagem de Probabilidade e Estatística no Ensino Médio. Analogamente ao que é ressaltado para a Matemática de maneira geral, o ensino-aprendizagem dos conteúdos deste campo também assumem uma dupla finalidade: a formativa e a instrumental.

Na Parte III dos PCNEM podemos verificar que:

As habilidades de descrever e analisar um grande número de dados, realizar inferências e fazer predições com base numa amostra da população, aplicar as ideias de probabilidade e combinatória a fenômenos naturais e do 
cotidiano são aplicações da Matemática em questões do mundo real que tiveram um crescimento muito grande e se tornaram bastante complexas. Técnicas e raciocínios estatísticos e probabilísticos são sem dúvida, instrumentos tanto das Ciências da Natureza quanto das Ciências Humanas. Isto mostra como será importante uma cuidadosa abordagem dos conteúdos de contagem, estatística e probabilidade no Ensino Médio, ampliando a interface entre o aprendizado da Matemática e das demais ciências e áreas. (BRASIL, 2000b, p. 44)

Neste trecho dos PCNEM, encontra-se explicitado o caráter instrumental do ensino-aprendizagem de Probabilidade e Estatística, bem como se destaca a sua relação com outras áreas do conhecimento, principalmente no que se refere às suas aplicações.

O caráter formativo também está associado ao ensino-aprendizagem deste campo, tal como evidenciamos nos PCN+ Ensino Médio, na parte de Matemática, mais especificamente no que se refere à Análise de dados, tema este que engloba os conteúdos de Estatística, Contagem e Probabilidade:

A Matemática do ensino médio pode ser determinante para a leitura das informações que circulam na mídia e em outras áreas do conhecimento na forma de tabelas, gráficos e informações de caráter estatístico. Contudo, espera-se do aluno nessa fase da escolaridade que ultrapasse a leitura de informações e reflita mais criticamente sobre seus significados. Assim, o tema proposto deve ir além da simples descrição e representação dos dados, atingindo a investigação sobre esses dados e a tomada de decisões. (BRASIL, 2002a, p. 126)

Com base no trecho acima, podemos constatar que diretamente associadas ao caráter instrumental do ensino-aprendizagem, estão também associados o desenvolvimento da criticidade, da capacidade investigativa e a tomada de decisões, evidenciando assim aquilo que pretendemos formar no indivíduo, ou seja, o caráter formativo.

Assim, o ensino-aprendizagem da Estatística que se detiver apenas às fórmulas e cálculos rotineiros, por exemplo, de médias e desvios, mas sem uma leitura crítica dos resultados obtidos, provavelmente não cumprirá com sua finalidade formativa e pouco contribuirá para o desenvolvimento da criticidade, da capacidade investigativa e a tomada de decisões.

Cabe pontuar também que tampouco podemos garantir que a finalidade instrumental foi alcançada pelo fato de algumas fórmulas terem sido utilizadas ao longo do trabalho com 
esses conteúdos, pois estando desprovidas de significado e finalidade, aos olhos dos estudantes elas provavelmente representarão apenas um emaranhado de símbolos e fórmulas cuja utilidade poderá ser resumida tão somente a sua aplicação na realização de avaliações escolares.

\title{
2.2 A utilização de tecnologias no ensino-aprendizagem na Educação Básica
}

De início, entendemos ser adequada uma breve análise do seguinte trecho da Parte I Bases Legais dos PCNEM, que discute sobre a chamada "revolução informática" e o lugar que a tecnologia passa a ocupar nas escolas.

\begin{abstract}
A denominada "revolução informática", promove mudanças radicais na área do conhecimento, que passa a ocupar um lugar central nos processos de desenvolvimento, em geral. É possível que, nas próximas décadas, a educação vá se transformar mais rapidamente do que em muitas outras, em função de uma nova compreensão teórica sobre o papel da escola, estimulada pela incorporação das novas tecnologias. (BRASIL, 2000a, p. 5)
\end{abstract}

Um ponto a se destacar sobre o trecho citado é que ele tenta, de algum modo, antecipar que a "revolução informática" poderia acarretar implicações profundas no contexto escolar, principalmente em virtude das modificações nos processos de construção e difusão do conhecimento.

É ressaltado também que essas tecnologias proporcionam diferentes modos de interação social, o que por si só demandará uma nova reorganização escolar, para que estas sejam, de algum modo, incorporadas. Caso contrário, a escola se encontrará defasada em relação ao rápido avanço tecnológico, podendo assim ocorrer um descompasso entre aquilo que a sociedade demanda do cidadão e o que a escola tem para oferecê-lo, para que ele possa suprir tal demanda.

Cabe pontuar que, preparar os jovens para o convívio em sociedade e o ingresso no mercado de trabalho, é uma das finalidades da educação escolar, conforme descrito no Artigo $1^{\circ}$ do Parágrafo $2^{\circ}$ da Lei ${ }^{\circ}$ 9.394/96 (BRASIL, 1996). 
Já no Inciso VII do Artigo 16 da Resolução CNE/CEB, no 2/2012 (BRASIL, 2012) ${ }^{10}$, que trata do projeto político-pedagógico das unidades escolares que ofertam o Ensino Médio e do que estas unidades devem considerar na elaboração de tal documento, podemos encontrar a recomendação que afirma ser necessária a "utilização de diferentes mídias como processo de dinamização dos ambientes de aprendizagem e construção dos saberes”.

Portanto, o que se espera é que a utilização de tecnologias possa contribuir para um melhor aproveitamento do tempo de trabalho em sala de aula e também na construção de saberes por parte dos estudantes.

A tecnologia então deve ser concebida como uma ferramenta que traz novas possibilidades de ensino-aprendizagem e, nesse sentido,

[...] deve-se estimular a busca de metodologias que promovam a melhoria da qualidade, sem necessariamente implicar na ampliação do tempo de permanência na sala de aula, tais como o uso intensivo de tecnologias da informação e comunicação. (BRASIL, 2013b, p. 190) ${ }^{11}$

O ambiente escolar, portanto, já não mais se constitui como o único espaço de aprendizagem e construção dos saberes escolares pelos estudantes. A perspectiva trazida pelas tecnologias é que não há um local específico para o acesso à informação, mas sim que este acesso pode ser possível nos mais diversos ambientes e utilizando-se diferentes meios.

Nesta linha de raciocínio, podemos pensar que cada indivíduo torna-se capaz de desenvolver seu próprio ritmo de aprendizagem e construção de saberes, ainda que este desenvolvimento dos conteúdos na escola esteja organizado partindo-se do pressuposto de que todos os estudantes possam acompanhá-lo em um mesmo ritmo, o que na realidade não ocorre.

\footnotetext{
${ }^{10}$ Resolução que define Diretrizes Curriculares Nacionais para o Ensino Médio.

${ }^{11}$ Diretrizes Curriculares Nacionais Gerais da Educação Básica.
} 


\title{
3 Tecnologias da Informação e Comunicação (TIC) na Educação
}

\author{
E acontece que justamente as novas tecnologias \\ oferecem uma maneira de educação diferente.
}

Michel Serres - filósofo

A utilização das Tecnologias da Informação e Comunicação (TIC) na Educação parece ser um tema em que não há um consenso, seja entre educadores e outras pessoas ligadas à Educação, quanto na sociedade de uma maneira mais ampla.

Dentre aqueles que defendem a implementação das TIC no processo de ensino-aprendizagem os argumentos variam, por exemplo, desde a inclusão digital dos estudantes e orientações para um uso responsável e seguro dos recursos disponíveis na internet, bem como a construção de saberes das disciplinas tidas como tradicionais por meio do uso da tecnologia.

Porém, a tecnologia por si só não será a responsável por melhoria alguma nos processos de ensino-aprendizagem, pois em si mesma ela não é boa nem é ruim, o que é preponderante é a utilização que faremos dela. Então, torna-se necessário não somente discutirmos as TIC no que se refere a questões de infraestrutura, mas tão importante quanto, será a forma como poderemos nos valer dela no processo de ensino-aprendizagem e quais fatores poderiam contribuir ou até mesmo dificultar seu uso.

O tema das TIC na Educação tem sido objeto de estudo de pesquisas nacionais e internacionais, algumas das quais serão mencionadas ao longo deste capítulo, e muito já se têm produzido na literatura sobre este tema. Devido à sua abrangência, torna-se até impossível que uma pesquisa consiga abarcar este assunto em seus variados aspectos. Assim, nosso intuito ao abordá-lo aqui é o de discutir alguns dos temas ligados às TIC que estejam diretamente relacionados ao objetivo que estabelecemos para este trabalho.

Pretendemos inicialmente discutir e estabelecer uma definição das TIC, bem como apresentaremos justificativas para sua utilização na Educação, oriundas da literatura científica. Acreditamos que a inserção das TIC como uma ferramenta nos processos de ensino-aprendizagem deva ser devidamente fundamentada, pois a sua utilização em sala de aula sustentada simplesmente pelo fato das TIC ser uma "novidade" não nos parece consistente.

Em seguida, vamos apresentar algumas concepções sobre a utilização das TIC na Educação, partindo-se do pressuposto que consideramos válida e justificada a sua inserção no 
processo de ensino-aprendizagem e daremos então um passo adiante para discutirmos o modo como elas podem ser integradas nesse processo. Para a realização de tal tarefa, iremos nos embasar principalmente em Almeida e Silva (2011), Valente (1998), Valente e Almeida (1997a; 2011), bem como em outros trabalhos que tratam deste assunto. Apresentaremos duas abordagens no uso dos computadores no processo de ensino-aprendizagem: a abordagem instrucionista e a abordagem construcionista.

O nosso terceiro ponto de discussão será a respeito de um olhar específico para a realidade das escolas brasileiras no que tange à problemática que se apresenta em relação ao uso das TIC no processo ensino-aprendizagem. Nossa fonte principal de informações será a pesquisa TIC Educação 2013 (CGI.br, 2014).

\subsection{As TIC e algumas das justificativas para a sua utilização na Educação}

3.1.1 Em busca de uma delimitação das TIC

O termo "tecnologia" é amplo e pode assumir uma diversidade de significados. Portanto, seu significado dependerá fundamentalmente daquilo que o autor pretende abordar. O que pretendemos neste momento é adquirir uma maior precisão em nosso discurso, por meio da delimitação do termo TIC que consideraremos para o decorrer do nosso trabalho.

Segundo Sancho (1998, apud ZUFFO, 2011) as tecnologias podem ser divididas em três categorias, cada uma delas abarcando consigo o seu respectivo significado e delimitações: as tecnologias físicas, as tecnologias simbólicas e as tecnologias organizadoras.

As tecnologias físicas são os instrumentos físicos propriamente ditos, tais como, caneta esferográfica, livro e computadores.

As tecnologias simbólicas estão vinculadas a forma de comunicação entre as pessoas, o modo como estão organizados os idiomas escritos e falados, bem como o próprio modo como as pessoas se comunicam. Por exemplo, a fala, a escrita e a imagem.

As tecnologias organizadoras são as formas como nos relacionamos com o mundo e como os sistemas produtivos estão organizados. Por exemplo, os processos manufatureiros e os processos industriais.

Por meio da classificação apresentada anteriormente, poderíamos provisoriamente conceber as TIC como sendo aparatos físicos capazes de suportar informações, bem como 
comunicá-las, ou seja, tecnologias físicas que trazem consigo elementos das tecnologias simbólicas.

Isso nos parece razoável, pois não estamos interessados em estudar o computador por si mesmo, ou seja, a sua estrutura física e os seus diversos componentes, mas sim o modo como este instrumento físico junto com os seus mais variados recursos provenientes de software podem contribuir no processo de ensino-aprendizagem.

Prosseguindo com a nossa investigação, podemos encontrar também em Wilson et al. (2012, p. 16) que as TIC e novas mídias são termos utilizados para descrever os aparatos que veiculam conteúdo multimodal digital e permitem comunicação de duas vias (celulares, computadores, entre outros). Os meios de comunicação em massa são tidos como aqueles que permitem a comunicação apenas de uma via, tais como, o rádio, o jornal e a televisão.

Deste modo, considerando as definições apresentadas em Sancho (1998, apud Zuffo, 2011) e Wilson et al. (2012, p. 16) entendemos ser apropriado neste momento conceituarmos então as TIC como sendo as tecnologias físicas que suportam elementos das tecnologias simbólicas e que permitem comunicação de duas vias: emissão e recepção de informações.

$\mathrm{Na}$ intenção de estudarmos as TIC com o intuito de utilizá-las para fins educativos, estaremos interessados nas tecnologias simbólicas que elas suportam e no modo como elas emitem e recebem informações, procurando então evidenciar de que modo estes dois elementos juntos podem contribuir para o ensino-aprendizagem.

Considerando a definição apresentada, estaremos assim incluindo certas tecnologias físicas como pertencentes ao conjunto das TIC, bem como deixaremos de fora outras. Por exemplo, os computadores, celulares e tablets, satisfazem a definição por nós estabelecida. Ao passo que os livros, o rádio e a televisão não se encaixam nesta definição, pois permitem apenas a comunicação de uma via, pois eles tradicionalmente suportam e emitem informações apenas.

\subsubsection{Duas justificativas para o uso das TIC na Educação}

Nossa primeira justificativa é proveniente da Filosofia, através das contribuições fornecidas por Lévy (1999). Neste trabalho, o autor procura discutir as mudanças ocorridas na sociedade com base no surgimento das mais variadas tecnologias. Ele refaz o percurso da história da humanidade sob o prisma da evolução das tecnologias, bem como as suas implicações sociais. 
O ponto de chegada de Lévy, que pode também ser considerado um ponto de partida, são as tecnologias digitais e suas implicações, aí reside o nosso interesse, já que compreender em que medida a nossa relação com os conhecimentos, a forma como interagimos uns com os outros e o modo como nos comunicamos são modificadas com o advento dessas tecnologias, nos poderá ser de grande valia para sustentarmos uma justificativa para a utilização das TIC no processo de ensino-aprendizagem.

Porém, antes de discutirmos as mudanças sustentadas pelo autor, torna-se necessário apresentarmos dois conceitos que se apresentam como centrais em Lévy (1999): o ciberespaço e a cibercultura.

No que se refere ao conceito de ciberespaço, Lévy nos esclarece que:

O ciberespaço (que também chamarei de "rede") é o novo meio de comunicação que surge da interconexão mundial dos computadores. O termo especifica não apenas a infra-estrutura material da comunicação digital, mas também o universo oceânico de informações que ele abriga, assim como os seres humanos que navegam e alimentam esse universo. (LÉVY, 1999, p. 17)

Quanto ao conceito de cibercultura, o autor procura caracterizá-lo como o "conjunto de técnicas (materiais e intelectuais), de práticas, de atitudes, de modos de pensamento e de valores que se desenvolvem juntamente com o crescimento do ciberespaço" (LÉVY, 1999, p. 17).

Assim, podemos compreender o ciberespaço como o mundo digital propriamente dito, onde pessoas podem se encontrar através da rede mundial de computadores, sendo composto também pelas informações e as pessoas que estão neste local. É como se cada um de nós pudesse materializar-se digitalmente no computador, encontrar-se com outras pessoas na rede mundial de computadores e trocar informações com elas.

Agora, com relação ao conceito de cibercultura, podemos concebê-lo como sendo as práticas e implicações sociais e culturais específicas que emergem do ciberespaço, pois se o modo como as pessoas se relacionam no mundo virtual é distinto do modo como elas se relacionam no mundo físico, isso acarreta uma série de implicações no modo como escrevemos, na forma de buscarmos informações, dentre outras demandas.

Lévy (1999, p. 32) define que as tecnologias digitais surgiram como a infraestrutura do ciberespaço e segundo o autor essas tecnologias propiciaram uma nova forma de organização, 
comunicação, sociabilização e transação de informações e disseminação de conhecimentos e, interessante para o nosso trabalho, é elucidar que:

[...] o ciberespaço suporta tecnologias intelectuais que amplificam, exteriorizam e modificam numerosas funções cognitivas humanas: memória (banco de dados, hiperdocumentos, arquivos digitais de todos os tipos), imaginação (simulações), percepção (sensores digitais, telepresença, realidades virtuais), raciocínios (inteligência artificial, modelização de fenômenos complexos). (LÉVY, 1999, p. 156)

Vejamos então um exemplo com intuito de compreender como nossas funções cognitivas poderiam ser amplificadas, exteriorizadas e modificadas. Consideremos brevemente o contexto do ensino de Probabilidade e Estatística na Educação Básica.

Suponhamos que um professor tenha como intenção trabalhar com os estudantes a compreensão dos conceitos de probabilidade teórica, frequência relativa esperada e frequência relativa observada. Além disso, para a realização desta tarefa ele deseja utilizar algum software capaz de realizar a simulação do lançamento de um dado equilibrado.

Ele poderia pedir aos estudantes que solicitassem ao software a simulação de 10, 100, 1.000, 10.000 lançamentos deste dado e que discutissem os resultados obtidos com outros colegas e com o professor, bem como confrontassem tais resultados.

Isso nos parece apropriado, pois além das explicações do professor, os estudantes teriam também a evidência fornecida pelo computador, podendo assim confrontar as argumentações dadas pelo professor e os resultados obtidos no computador.

Neste caso, o computador seria capaz de amplificar e exteriorizar nossas capacidades de imaginação, raciocínio e memória, pois ele estaria simultaneamente realizando a simulação de um experimento, armazenando os dados obtidos e apresentando-os, algo que provavelmente seria inviável de se realizar em sala de aula sem a utilização deste recurso.

Uma segunda justificativa para a utilização das TIC na Educação, com base em Valente (1998), refere-se ao uso do computador no ensino-aprendizagem e como ele pode ser utilizado como um instrumento de enriquecimento da prática do professor e construção do conhecimento por parte do estudante. Cabe destacar, entretanto, que mesmo o autor tratando 
especificamente da inclusão dos computadores no processo de ensino-aprendizagem, acreditamos que suas afirmações possam ser extrapoladas para as TIC em geral ${ }^{12}$.

[...] o computador pode enriquecer ambientes de aprendizagem onde o aluno, interagindo com os objetos desse ambiente, tem chance de construir o seu conhecimento. Nesse caso, o conhecimento não é passado para o aluno. $\mathrm{O}$ aluno não é instruído, ensinado, mas é o construtor do seu próprio conhecimento. Esse é o paradigma construcionista onde a ênfase está na aprendizagem ao invés de estar no ensino, na construção do conhecimento e não na instrução. (VALENTE, 1998, p. 30)

Podemos assim interpretar que a justificativa sustentada pelo autor para a integração dos computadores na Educação é exatamente a potencialidade destes equipamentos em tornar o estudante protagonista e também responsável pela construção do seu próprio conhecimento, deslocando o foco do ensino para a aprendizagem.

Nesse sentido, vislumbra-se uma mudança de paradigma: de um conhecimento que é supostamente passível de ser transmitido, onde o professor é o instrutor e o estudante é o reprodutor das ideias comunicadas pelo professor, para um conhecimento que é considerado passível de ser construído, onde o professor é o mediador e o estudante é o construtor do seu próprio conhecimento.

\subsection{Algumas abordagens no uso dos computadores na Educação}

Nesta seção, discutiremos duas das principais abordagens no uso dos computadores em sala de aula: a instrucionista e a construcionista.

Nossas discussões serão encaminhadas principalmente com base em Almeida e Silva (2011), Valente (1998) e Valente e Almeida (1997a; 2011), dentre outros pesquisadores.

Pontuamos que, apesar dos autores estarem argumentando especificamente sobre a integração dos computadores no processo de ensino-aprendizagem, acreditamos que expandi-los e aproveitá-los para as TIC de um modo geral não irá se configurar como uma generalização excessiva, na medida em que os computadores foram os precursores da inserção

\footnotetext{
${ }^{12}$ Com efeito, pois Valente em um trabalho posterior apresenta sua posição favorável não somente em relação aos computadores, mas também em relação às Tecnologias Digitais de Informação e Comunicação (TDIC) de modo geral, tal como pode ser verificado em Valente e Almeida (2011).
} 
de tecnologias na sala de aula, deste modo, nossas reflexões sobre os possíveis usos que faremos das demais TIC podem se valer das experiências já realizadas com a utilização dos computadores.

Cabe destacar aqui que, como qualquer tentativa de classificação, ela é arbitrária e traz consigo as concepções que o(s) autor(es) possui(em) $)^{13}$.

\subsubsection{A abordagem instrucionista}

A introdução das tecnologias de informática com finalidade voltada para o ensino surgiu aproximadamente na metade da década de 20 no século passado, com a invenção de uma máquina destinada para a apresentação de conteúdos, aplicação e correção de testes de múltipla escolha, a chamada Máquina de Pressey, denominada assim em alusão ao seu inventor, o Dr. Sidney Pressey.

Posteriormente, já na década de 60, foi proposta uma abordagem no uso dos computadores no ensino, onde este assumiria o papel de uma "máquina de ensinar" por meio da implementação de software do tipo instrução assistida por computador (do inglês computer assisted instruction).

As teorias subjacentes a essa abordagem estavam embasadas nos desenvolvimentos realizados na década de 50 na área da Psicologia, ligada ao estudo do comportamento, mais precisamente, através dos trabalhos do psicólogo e professor de Harvard, B. F. Skinner. (ALMEIDA; SILVA, 2011, VALENTE, 1998)

Os software do tipo instrução assistida por computador traziam consigo os conteúdos de ensino a serem ensinados pelo computador e em sua maioria eles eram do tipo exercício-e-prática (do inglês drill-and-practice). O ensino era individualizado e o estudante avançava na aprendizagem dos conteúdos, baseado em seus erros e acertos conferidos automaticamente pela máquina. Nesse sentido,

[...] foram construídas e testadas diversas versões de "máquina para ensinar", cujo uso se baseava na ideia da aprendizagem individualizada e no reforço (positivo ou negativo) imediatamente após o acerto ou erro em forma de sons, de progresso nas lições ou de estímulos visuais. (ALMEIDA; SILVA, 2011, p. 28)

\footnotetext{
${ }^{13}$ Existem outros tipos de classificações sobre o uso das TIC na Educação, conforme podemos verificar em Almeida (2008, p. 100) quando faz referência a Costa (2004).
} 
Com o passar do tempo e a evolução dos recursos de informática, não somente no que se refere ao hardware, mas também ao software, foram surgindo outros programas que, apesar de serem diferentes daqueles do tipo exercício-e-prática, carregam consigo as ideias por trás da "máquina de ensinar", como no caso dos tutoriais. Nestes programas, o conteúdo de ensino é apresentado de modo semelhante aquilo que já é realizado em uma aula tradicional e pode-se dizer que este tipo de programa representa uma informatização do ensino tradicional.

Essa utilização dos computadores, com base em uma abordagem instrucionista, mesmo sendo uma espécie de substituto da prática de ensino tradicional pode mostrar-se útil e importante em certas situações. Por exemplo, no caso de um estudante que faltou a uma aula e necessita estudar os conteúdos nesse mesmo dia para que ele possa acompanhar a aula do dia seguinte. Nessa situação, assistir a uma videoaula do conteúdo que foi trabalhado pelo professor poderá auxiliar no acompanhamento da próxima aula.

Por outro lado, entendemos que utilizar os computadores ou, mais ainda, as TIC, de um modo geral, somente através da abordagem instrucionista poderá configurar-se como uma subutilização destas tecnologias. Com efeito, pouco se aproveitará do leque de possibilidades que tais tecnologias oferecem, principalmente no que se refere ao vislumbre de ampliar, exteriorizar e modificar nossas capacidades cognitivas, tal como pontua Lévy (1999).

$\mathrm{Na}$ abordagem instrucionista, o centro do processo de ensino-aprendizagem é deslocado do professor para o computador, porém, a posição do estudante mantém-se inalterada: ele continua sendo um receptor passivo de informações.

Quando do surgimento da abordagem instrucionista do uso dos computadores em meados da década de 60, os entusiastas dessa abordagem acreditavam que ela seria de tal forma frutífera e capaz de revolucionar a educação que, em um futuro próximo, a figura do professor seria suprimida pela máquina, pois "naquele momento, os esforços convergiam para a conversão dos conteúdos das aulas em softwares - concepção que traduzia o enfraquecimento do papel do professor" (ALMEIDA; SILVA, 2011, p. 28).

Fica claro que tal projeção não se concretizou e o papel do professor no ensino-aprendizagem não poderia ser simplesmente suprimido pela máquina. E assim, com o desejo de propor uma outra forma de utilização dos computadores no ensino é que surgiu a abordagem construcionista. 


\subsubsection{A abordagem construcionista}

As raízes da abordagem construcionista estão situadas nos trabalhos do matemático sul-africano Seymour Papert, por meio da criação da linguagem de programação Logo. Papert desenvolveu pesquisas e lecionou no Instituto de Tecnologia de Massachussets (MIT) nos Estados Unidos da América. Além disso, ele estudou com Jean Piaget em Genebra no final da década de 1950 (VOELCKER, 2012, p. 32).

O contato de Papert com Piaget, bem como as ideias de outros pensadores da Educação tiveram uma influência decisiva para o surgimento da abordagem construcionista e a linguagem de programação Logo, pois

Papert (1985; 1994), influenciado pela epistemologia genética de Piaget e pelas ideias de outros pensadores, entre os quais se destacam Dewey, Vygotsky e Paulo Freire, concebeu a abordagem construcionista e a linguagem de programação Logo para uso do computador em educação em oposição ao uso do computador como máquina de ensinar, segundo a abordagem instrucionista. (VALENTE; ALMEIDA, 2011, p. 34)

No que se refere a uma conceituação da abordagem construcionista no uso dos computadores no ensino, segundo as ideias do matemático sul-africano Seymour Papert, temos que nessa abordagem é o aprendiz que "constrói, através do computador, o seu próprio conhecimento" (VALENTE, 1998, p. 40).

A ideia subjacente à abordagem construcionista é que o estudante, na interação com o computador, seja capaz de construir os seus próprios conhecimentos. O estudante deve assumir uma postura ativa perante a máquina, tomando para si uma grande dose de responsabilidade no que diz respeito ao desenvolvimento dos seus saberes e não mais atuando como um receptor passivo de informações emitidas por esta última.

Neste caso, a utilização de software do tipo linguagem de programação, tais como Logo e Pascal, mostrou-se particularmente apropriada, pois a ideia central era que o estudante poderia utilizar essas linguagens de programação na resolução de problemas.

Nesse processo de interação com a máquina, raciocinando e comunicando-se com ela por meio das linguagens de programação, ensinando-a a executar tarefas, bem como refletindo e discutindo os resultados apresentados pela máquina é o que lhe possibilitaria construir seus próprios conhecimentos. 
Além disso, o processo de interação entre o estudante e a máquina pode ser tanto mais potencializado quanto mais apropriada for a mediação do professor, no sentido de incentivá-lo e auxiliá-lo nas dificuldades que possam surgir na resolução dos problemas propostos.

O professor não deve somente fornecer a máquina ao estudante e propor ou utilizar algum problema de seu interesse pois, sem o devido auxílio, é provável de acontecer que o estudante perca o interesse pela resolução do problema, caso venham a surgir equívocos em seu raciocínio os quais ele sozinho não consiga detectar.

Assim, destaca-se que além de selecionar os recursos tecnológicos a serem utilizados e os problemas a serem resolvidos, o professor deve orientar o estudante na sua interação com o computador, para que tal interação venha de fato potencializar o aprendizado do estudante.

Diferentemente da abordagem instrucionista, o professor não é substituído pela máquina, entretanto, deixa também de ocupar uma posição central no processo de ensino-aprendizagem pois, o foco é deslocado do ensino para a aprendizagem.

Entendido que no processo de resolução de um problema com o auxílio do computador, do professor e de seus colegas de estudo, o estudante é capaz de construir os seus próprios conhecimentos, iremos agora estudar de forma um pouco mais detalhada como se dá esse processo e que está descrito em Valente (1997a; 1997b) como o ciclo descrição-execução-reflexão-depuração.

\subsubsection{O ciclo descrição-execução-reflexão-depuração}

O processo de interação do estudante com o computador é descrito em Valente (1997a; 1997b) como sendo um ciclo - descrição-execução-reflexão-depuração -, segundo as ideias de Papert.

Em virtude da abordagem construcionista estar diretamente vinculada a software do tipo linguagem de programação, as caracterizações apresentadas mostram-se dirigidas a estes, porém, acreditamos que este ciclo ou algumas das partes dele podem possuir representantes análogos com algumas alterações, quando da utilização de outros software que não são do tipo linguagem de programação, tais como os ambientes de geometria dinâmica, simulações dentre outros.

Vejamos agora, com base em Valente (1997a; 1997b) como se caracteriza o ciclo descrição-execução-reflexão-depuração, quando o estudante interage com o computador com 
a intencionalidade de utilizá-lo para a resolução de um problema através de uma linguagem de programação, segundo a abordagem construcionista:

i) descrição: o estudante descreve para o computador aquilo que ele deverá executar por meio de uma série de comandos escritos em uma linguagem formal e precisa, por meio de uma linguagem de programação;

ii) execução: o estudante solicita ao computador que ele execute os comandos descritos;

iii) reflexão: após a execução dos comandos solicitados pelo estudante, o computador lhe apresenta uma resposta para o problema que ele estava interessado em resolver. O estudante interpreta a resposta fornecida pelo computador e verifica a adequação desta com o problema em questão. Caso a resposta seja compatível com o esperado, então, isso é um indício de que a descrição dos comandos para o computador foi realizada corretamente e assim é dada continuidade às atividades de aprendizagem. Caso contrário, ele deverá depurar, refinar, aprimorar suas ideias e até mesmo corrigir a sua descrição de comandos para o computador, eis a depuração;

iv) depuração: considerando o caso onde a resposta apresentada pelo computador não seja consistente com o problema, o estudante deverá então repensar suas ideias, refazer o seu raciocínio e até mesmo buscar outros conceitos que possibilitem a resolução do problema e assim, o ciclo inicia-se novamente. O estudante descreverá uma nova série de comandos a serem executados pelo computador, solicitará ao computador a execução dos comandos descritos etc.

Ao expandirmos o ciclo descrito para outros tipos de software que não requerem necessariamente uma programação completa para o seu uso, tais como o Geogebra ${ }^{14}$, podemos verificar que o referido processo pode apresentar modificações.

Em virtude de alguns comandos já se fazerem existentes no programa, a tarefa de descrição assumirá uma outra perspectiva, diferente daquela que ocorre nas linguagens de programação, pois será no sentido de indicar os elementos necessários para a execução de um determinado comando, tendo previamente estabelecido qual comando será acionado a partir da indicação de tais elementos. Por exemplo, no caso da ferramenta "Reta Perpendicular" devemos primeiro acioná-la e depois selecionamos o ponto e a reta ou semirreta ou segmento de reta ou vetor a serem considerados na sua execução.

\footnotetext{
${ }^{14} \mathrm{O}$ Geogebra é um ambiente de geometria dinâmica geralmente utilizado para o ensino-aprendizagem de Geometria. Ele é um software livre e gratuito para o usuário. Para o leitor interessado em maiores informações sobre este recurso sugerimos o site: $<$ https://www.geogebra.org/>.
} 
Entretanto, acreditamos que as etapas reflexão e depuração seguem ainda nos moldes em que foram concebidas para o contexto das linguagens de programação, pois tais etapas estão sob a responsabilidade do estudante. No entanto, cabe pontuar que a consistência e qualidade do feedback dado pelo programa são relevantes para que o estudante possa avaliar criticamente a pertinência da solução.

Nesse ir-e-vir, nesse fazer-pensar, enfim, realizando continuamente este ciclo de descrição-execução-reflexão-depuração é que, do ponto de vista da abordagem construcionista, os conhecimentos do estudante podem ser construídos através da interação com o computador.

3.2.4 Existe alguma abordagem que pode ser considerada como "mais apropriada" no uso dos computadores no ensino?

Após a apresentação das abordagens instrucionista e construcionista, bem como do ciclo descrição-execução-reflexão-depuração (VALENTE, 1997a; 1997b), poderíamos supor que a abordagem construcionista é a mais apropriada no uso dos computadores no ensino e, portanto, qualquer abordagem do tipo instrucionista deveria ser evitada. No entanto, Valente (1997b) pondera que o uso inteligente do computador no ensino será aquele que estiver melhor alinhado com os objetivos pedagógicos pretendidos pelo professor quando do desenvolvimento de um conteúdo com seus estudantes e o fundamental é que essa intervenção possa vir a potencializar a aprendizagem dos estudantes.

Portanto, cabe ao professor decidir qual abordagem será implementada no uso dos computadores com seus estudantes e assim, qualquer intervenção pretendida com a utilização dos computadores ou quaisquer outras TIC deve ser precedida por um planejamento minucioso das atividades e uma reflexão dos efeitos esperados sobre a aprendizagem.

Além do que, conforme nos alertam Valente e Almeida (2011, p. 29), a inserção e utilização de tecnologias no processo de ensino-aprendizagem de modo algum deve ser considerada apenas como uma "digitalização" da prática de ensino tradicional, no sentido de se pensar que está apenas alocando os conteúdos dos materiais impressos tradicionais como livros e apostilas para as mídias digitais. Isso não procede, pois ao adotar um novo meio de veicular as informações, tanto a forma como os conteúdos serão modificados.

Após estudarmos algumas das justificativas e abordagens no uso dos computadores no ensino, iremos agora voltar nossos olhares sobre o cenário contemporâneo das TIC nas 
escolas brasileiras, embasados principalmente nos resultados apresentados na pesquisa TIC Educação 2013 (CGI.br, 2014).

\subsection{Um breve panorama do acesso e utilização das TIC nas escolas brasileiras}

As discussões e preocupações com a inclusão e utilização das TIC no processo de ensino-aprendizagem estão ganhando cada vez mais espaço nos mais diversos ambientes sociais e pode-se até dizer que já se faz presente há algum tempo na pauta dos governos da maioria dos países, bem como de diversas organizações internacionais, tais como a Organização das Nações Unidas para a Educação, a Ciência e a Cultura (UNESCO), a Comunidade Europeia e o Banco Interamericano de Desenvolvimento (BID). ${ }^{15}$

Nos diversos documentos elaborados por tais organizações no que se refere às TIC na Educação, podemos encontrar preocupações e propostas, tanto em termos de infraestrutura para o uso das TIC, bem como sobre a utilização destas tecnologias com o intuito de uma melhoria nos processos de ensino-aprendizagem. A questão chave por trás dessas discussões é a de que o rápido avanço das tecnologias está promovendo mudanças na sociedade em um ritmo acelerado e a tecnologia está cada vez mais presente no cotidiano de quase todas as pessoas.

Entretanto, o ensino tradicionalmente oferecido pelas escolas já não é capaz de propiciar aos estudantes o desenvolvimento das capacidades que lhes serão requisitadas para o convívio em plenitude na sociedade, e o que podemos evidenciar é que: "A lacuna entre o mundo real e a escola nunca esteve tão grande e, até mesmo as escolas que obtém os melhores escores nos testes padronizados não preparam os jovens para o mundo adulto da sociedade atual" (WAGNER, 2008 apud VOELCKER, 2012).

Constatando-se esse descompasso entre o que é oferecido pela formação escolar tradicional e aquilo que está sendo e será requisitado do jovem ao final da Educação Básica, argumenta-se que a integração das TIC no contexto escolar representa uma possibilidade de avanço nessa questão.

De fato, pois embora as TIC não representem uma solução definitiva para todos os problemas da Educação, elas podem propiciar um outro modo de ensinar e de aprender: “[...]

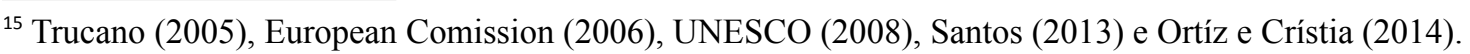


se é fato que as TIC sozinhas - e em seu melhor uso - não podem resolver importantes problemas na educação, será ainda mais difícil aspirar a uma educação de qualidade em uma sociedade conectada se essas tecnologias não estiverem presentes" (IRDC, 2012 apud CGI.br, 2014).

$\mathrm{Na}$ intenção de investigar em que medida tal descompasso está sendo corrigido no cenário da Educação Básica no Brasil é que desenvolvemos esta seção.

Nossa principal referência para o encaminhamento de nossas discussões são os resultados da pesquisa TIC Educação 2013 (CGI.br, 2014) do Comitê Gestor da Internet no Brasil (CGI.br), pesquisa esta que procura fornecer um quadro detalhado sobre o acesso e a utilização das TIC nas escolas brasileiras, bem como os diferentes usos que estudantes e professores fazem dessas tecnologias. Como uma breve ressalva, cabe destacar aqui que a pesquisa foi realizada apenas em escolas situadas em regiões urbanas do país.

Em virtude dos nossos objetivos e também após verificarmos a variedade de temas que são abordados na pesquisa, faremos um recorte em tal estudo (CGI.br, 2014), favorecendo somente os pontos pertinentes ao nosso trabalho.

\subsubsection{As TIC nas escolas públicas}

A grande maioria de matrículas na Educação Básica está situada nas escolas públicas (CGI.br, 2014), portanto, torna-se particularmente interessante para nós investigarmos como está o acesso e utilização das TIC nessas escolas, tanto pelos estudantes como pelos professores.

Segundo CGI.br (2014) os computadores já se fazem presentes em praticamente todas as escolas públicas das regiões urbanas do país, e em 73\% delas, além dos computadores, já existe ao menos um computador portátil, seja ele um notebook, netbook ou laptop.

Porém, saber que a presença dos computadores nas escolas públicas das regiões urbanas do país está praticamente universalizada não é suficiente para concluirmos que o acesso a estes pelos estudantes e professores nas situações de ensino-aprendizagem estará viabilizado, pois um outro dado relevante é aquele referente à quantidade de computadores que estão presentes nas escolas.

Em 2013, as escolas públicas possuíam, em média, 19,1 computadores de mesa instalados em funcionamento. Tendo em vista que tais unidades de 
ensino possuem, em média, 653 alunos, fica evidente a limitação para um uso individualizado dos equipamentos no cotidiano das escolas - mesmo levando em conta seus turnos de funcionamento. (CGI.br, 2014, p. 139)

O cenário descrito é que apesar dos computadores estarem presentes em praticamente todas as escolas públicas do país, a quantidade de computadores por unidade escolar é insuficiente, o que pode configurar um entrave para a sua utilização no processo de ensino-aprendizagem, sobretudo porque uma parte dessas máquinas é usada apenas para tarefas administrativas da escola e provavelmente não estão disponíveis como uma ferramenta para o ensino.

Outro ponto a ser destacado em CGI.br (2014) é que em apenas 6\% das escolas públicas pesquisadas existem computadores em sala de aula e o modelo predominante ainda é o do laboratório de informática, pois $85 \%$ das escolas pesquisadas afirmaram possuí-lo. Isso ainda pode se constituir como um obstáculo para a integração das TIC no ensino-aprendizagem das mais diversas disciplinas, já que o modelo baseado no laboratório de informática preconiza, na maioria dos casos, o ensino exclusivo de informática.

Entretanto, a tendência é o modelo do laboratório de informática ser substituído aos poucos por outros modos de implementação das TIC, de modo que estas tecnologias possam ser efetivamente utilizadas nas disciplinas que são tradicionalmente ensinadas em sala de aula.

\begin{abstract}
A forte tendência nos países industrializados é de se distanciar dos modelos baseados em laboratório de informática em prol das tecnologias educativas. Uma das razões por trás disso é bastante prática: os laboratórios de informática já estão cheios de computadores e, se a intenção é comprar mais desses equipamentos, é preciso colocá-los em outros lugares. Reconhece-se também que se o objetivo é que os computadores e as TIC contribuam diretamente para o processo de aprendizagem nas principais matérias que estão sendo ensinadas - como nas salas de aula. A mudança para o modelo de informática "um para um", em que cada aluno (e/ou professor) tem seu próprio laptop, pode ser vista em alguns aspectos como um prolongamento dessa crença. (TRUCANO, 2012, p. 66)
\end{abstract}

Além de questões referentes ao número de equipamentos disponíveis, bem como a sua localização nas escolas, entendemos que para o uso das TIC em sua plenitude é necessária a disponibilidade de acesso à internet, preferencialmente por meio de conexão sem fío e que 
apresente, ao menos, o mínimo de velocidade suficiente para a utilização dos recursos disponíveis na web que serão utilizados com finalidades educativas, pois diante da falta de computadores, poderão ser utilizados eventualmente os celulares ou tablets dos professores e estudantes. Entretanto, nesses três quesitos, as escolas públicas de maneira geral mostram-se aquém do ideal, tal como é apresentado em CGI.br (2014).

Neste momento, cabe destacar aqui outro fato trazido à tona por esta mesma pesquisa. No que diz respeito às dificuldades para a implementação das TIC com finalidade pedagógica, a pesquisa (CGI.br, 2014) aponta que segundo entrevista realizada com os diretores das escolas, eles consideram que os principais fatores tidos como impeditivos para tal eram os seguintes: baixa velocidade de conexão de internet, número insuficiente de computadores e ausência de suporte técnico.

Desse modo, o quadro que se apresenta é o seguinte: o número de computadores disponíveis para uso pedagógico já é reduzido, somando-se a isso, a ausência de manutenção periódica nos computadores já existentes, bem como a falta de conserto nos que estão quebrados e a conexão de internet demasiada lenta.

Porém, mesmo estando situados em um ambiente que não lhes propicia todos os recursos estruturais necessários para o uso das TIC com os estudantes nas atividades de ensino, os professores têm encontrado e implementado soluções alternativas para superar essas dificuldades, sendo que a mais comum citada em CGI.br (2014) é a do docente levar para a escola o seu computador pessoal, o que demonstra o seu interesse na utilização das TIC no ambiente escolar.

Portanto, faz-se necessário colocar em questão a formação do professor para o uso das TIC. O que a pesquisa TIC Educação 2013 (CGI.br, 2014) constatou é que o preparo dos professores para a utilização das TIC ainda mostra-se insuficiente, além disso, é preocupante também o fato das escolas pouco estarem se mobilizando no sentido de promover iniciativas com o intuito de prover formação adequada para o professor utilizar as TIC ou tampouco subsidiá-las.

Entretanto, novamente o professor toma para si uma responsabilidade que deveria ser, em nosso ver, compartilhada, pois outros resultados dessa mesma pesquisa indicam que a maioria dos docentes que realizaram alguma formação específica voltada para o uso das TIC em atividades pedagógicas, $78 \%$ assim o fizeram com recursos próprios, enquanto que em apenas $22 \%$ dos casos foram financiados com recursos governamentais, como por exemplo das secretarias de Educação. Ainda segundo essa mesma investigação (CGI.br, 2014), a 
maioria dos professores (96\%) alegaram já terem utilizado algum recurso da internet no preparo de suas aulas ou em atividades com os estudantes.

A pesquisa TIC Educação 2013 (CGI.br, 2014) constatou que apesar da maioria dos estudantes das escolas públicas já terem incorporado as TIC nas suas atividades do cotidiano, a sua utilização para atividades de aprendizagem ainda não é uma realidade. Os estudantes utilizam as tecnologias na realização de diversas atividades, tais como o envio de mensagens de texto, a "postagem" de fotos em redes sociais e a realização de compras na internet. No entanto, a utilização das TIC no aprendizado dos conteúdos escolares é algo ainda pouco aproveitado pelos estudantes.

Se nas escolas públicas evidenciam-se diversos obstáculos a utilização das TIC como ferramentas no ensino-aprendizagem, a realidade encontrada nas escolas particulares mostra-se relativamente distinta daquela das escolas públicas. É o que apresentaremos na seção seguinte.

\subsubsection{As TIC nas escolas particulares}

Os resultados apresentados em CGI.br (2014) mostram que a presença de computadores nas escolas particulares mostra-se praticamente universalizado, pois $98 \%$ delas já possuem tais equipamentos. No entanto, cabe pontuar que dentre as escolas particulares que possuem computadores o local onde há menos equipamentos é a sala de aula (23\%). Os principais locais de instalação dos computadores são a sala do coordenador pedagógico ou do diretor (93\%) e o laboratório de informática (71\%). O número de escolas que estão adquirindo tablets vêm aumentando, além disso, o número médio de computadores nas escolas destinados para o uso pedagógico é maior se comparado com o das escolas públicas ${ }^{16}$.

Outra informação apresentada na pesquisa é que 99\% das escolas particulares já possuem computadores com acesso à internet e que $81 \%$ delas já o fazem por meio de conexão sem fio. Esta possibilidade mostra-se particularmente interessante na medida em que a maioria dos estudantes já possui aparelho celular que possibilita conexão à internet: “A principal tendência relativa à mobilidade dos equipamentos entre os alunos é o acesso à

\footnotetext{
${ }^{16}$ Segundo CGI.br (2014): "[...] 13\% dos diretores afirmam que a escola possui tablets - um aumento de seis pontos percentuais em relação a 2012". Já nesta mesma pesquisa, no que se refere ao número médio de computadores destinado para o uso pedagógico, temos que: "Em média, 22 computadores presentes na escola são disponibilizados para o uso pedagógico (nas escolas públicas, essa média é de 17)”. As médias verificadas são muito baixas e tanto nas escolas particulares como nas escolas públicas, os resultados obtidos são menores que o número médio de alunos do Ensino Fundamental II e Médio dessas instituições respectivamente.
} 
Internet via celular, proporção que cresce de 44\%, em 2011, para 73\%, em 2013” (CGI.br, 2014, p. 165).

O estudo também constata a tendência na substituição do modelo de laboratório de informática para outros tipos de modelos de implementação das TIC nas escolas, tal como a utilização de computadores e tablets com acesso à internet em sala de aula.

Por fim, o último resultado verificado na pesquisa TIC Educação 2013 (CGI.br, 2014) é que, de maneira geral, tanto os professores das escolas particulares, bem como os professores das escolas públicas fazem o mesmo uso das TIC para a preparação das suas aulas, porém, os professores das escolas particulares contam com um maior incentivo da coordenação e da direção da escola do que nas escolas públicas.

Com base nos resultados até agora discutidos por nós, entendemos ser fundamental o fortalecimento das políticas públicas em TIC voltadas para as escolas públicas e particulares desde a infraestrutura para o acesso adequado às TIC até a implementação de programas de formação de professores, para que possamos enfim, começar a corrigir aos poucos o descompasso entre a formação oferecida pela escola e as capacidades e habilidades que são e serão requisitadas do jovem estudante, seja no mercado de trabalho ou nas mais variadas tarefas que ele desempenha ou desempenhará futuramente. 


\section{Educação Estatística}

No final século XIX, os erros haviam aumentado, em vez de diminuir. À proporção que as medições se tornavam mais precisas, novos erros se revelavam. [...] Gradualmente, a ciência começou a trabalhar com um novo paradigma, o modelo estatístico da realidade. No final do século $\mathrm{XX}$, quase toda ciência tinha passado a usar modelos estatísticos.

David Salsburg - estatístico

Pretendemos inicialmente situar as especificidades da Probabilidade e Estatística com base em Franklin et al. (2007) e Campos, Wodewotzki e Jacobini (2011). Entendemos que tais esclarecimentos tornam-se apropriados, pois ainda que no âmbito escolar os conteúdos de Probabilidade e Estatística sejam ensinados na disciplina de Matemática é preciso ter clareza que este campo possui seus objetos e métodos de estudo específicos, que por sua vez diferem dos da Matemática, pois ainda que tal campo faça uso desta, assim como a Física ou a Química também o fazem, ele não é simplesmente uma subárea da Matemática, tal como destacam Pfannkuch e Wild (2004, p.17) ${ }^{17}$.

Em seguida, apresentamos e discutimos os conteúdos de Estatística que são sugeridos a serem desenvolvidos no Ensino Médio com base nos PCN+ Ensino Médio (BRASIL, 2002a). Avançando em nossos estudos, discutiremos posteriormente sobre algumas das possibilidades de utilização das TIC no ensino-aprendizagem da Estatística no Ensino Médio.

\subsection{As especificidades da Estatística}

Primeiramente, entendemos ser apropriado destacar que ainda que a Estatística, bem como a Matemática venha a trabalhar com números (mas não somente isso), enquanto que no campo da Matemática, os próprios números podem vir a ser objetos de estudo, destituídos de qualquer contexto externo a ela, isso não ocorre na Estatística.

Conforme Moore e Cobb (1997 apud FRANKLIN et al., 2007, p.7) assinalam, o contexto é essencial na Estatística, é ele que provê significado aos números, os quais são chamados de dados e que após as devidas análises são "transformados" em informações.

\footnotetext{
17 "Statistics did not originate within mathematics. It is a unified logic of empirical science that has largely developed as a new discipline since the beginning of the $20^{\text {th }}$ century".
} 
Os dados são números situados em um contexto ${ }^{18}$. Portanto, para que possamos compreender, por exemplo, os resultados obtidos através de uma simples análise descritiva é necessário nos situarmos no contexto em que esses dados foram originados, para que estejamos assim em condições de realizar as devidas interpretações.

Outra característica que difere a Estatística da Matemática é o seu caráter não determinístico, principalmente através dos conceitos de aleatoriedade e incerteza, conforme destacam Campos, Wodewotzki e Jacobini.

[...] os conteúdos e valores da Estatística são, em geral, distintos daqueles da Matemática. Princípios como os da aleatoriedade e da incerteza se diferenciam dos aspectos mais lógicos ou determinísticos da Matemática. A existência de faces mais subjetivas, tais como a escolha da forma de organização dos dados, a interpretação, a reflexão, a análise e a tomada de decisões, fazem com que a Estatística apresente um foco diferenciado da Matemática. (CAMPOS; WODEWOTZKI; JACOBINI, 2011, p.13)

Cabe destacar também que ainda que na Matemática existam problemas que possam ser enfrentados através de abordagens distintas, na maioria dos casos deve-se chegar a uma única solução (quando ela existe) e, no caso de duas pessoas obterem resultados distintos para um mesmo problema (salvo exceções) pode-se concluir (na maioria dos casos) que alguma delas obteve uma resposta incorreta.

Tal fato é ainda mais reforçado quando nos referimos à Matemática no âmbito escolar, onde geralmente priorizam-se as soluções em detrimento das resoluções. Por outro lado, na Estatística, o fato de duas pessoas terem obtido resultados distintos para um mesmo problema não é uma condição necessária e suficiente para concluirmos que alguma delas tenha cometido algum equívoco ou erro quando da sua resolução.

Se a Estatística possui suas especificidades, torna-se apropriado também evidenciarmos as especificidades do seu ensino-aprendizagem.

\footnotetext{
18 " [...] Statistics requires a different kind of thinking, because data are not just numbers, they are numbers with a context. In mathematics, context obscures structure. In data analysis, context provide meaning." (MOORE; COBB, 1997 apud FRANKLIN et al., 2007, p.7)
} 


\subsection{Educação Estatística no Ensino Médio}

Nos PCN+ Ensino Médio (BRASIL, 2002a) os conteúdos de ensino da Matemática do Ensino Médio estão organizados através de temas estruturadores ${ }^{19}$ e eles são os seguintes: i) Álgebra: números e funções; ii) Geometria e medidas e; iii) Análise de dados. Especificamente no que se refere ao tema Análise de dados, tal documento afirma que:

[...] tem como objetos de estudo os conjuntos finitos de dados que podem ser numéricos ou informações qualitativas, o que dá origem a procedimentos bem distintos daqueles dos demais temas, pela maneira como são feitas as quantificações, usando-se processos de contagem combinatórios, frequências e medidas estatísticas e probabilidades. Este tema pode ser organizado em três unidades temáticas: Estatística, Contagem e Probabilidade. (BRASIL, 2002a, p. 126)

Neste trabalho não contemplaremos os conteúdos relativos à Contagem, portanto, no que se refere ao tema estruturador "Análise de dados" estaremos interessados apenas nas unidades temáticas de Probabilidade e Estatística, com ênfase em Estatística. Além disso, pontuamos que no Guia do Programa Nacional do Livro Didático (PNLD) de 2015, o tema de Análise Combinatória corresponde ao campo de Números.

Com respeito aos conteúdos de ensino descritos nesta unidade temática de Estatística, nos PCN+ Ensino Médio (BRASIL, 2002a, p.127) podemos encontrar: descrição de dados, representações gráficas e análise de dados (médias, moda e mediana, variância e desvio padrão).

\subsubsection{O ensino-aprendizagem da Estatística}

Conforme vimos anteriormente, os conteúdos de ensino da Estatística sugeridos a serem abordados no Ensino Médio são aqueles que dizem respeito à Estatística Descritiva ${ }^{20}$. Nesse nível de ensino trabalha-se principalmente com a organização e representação de dados

19 Segundo os PCN+ Ensino Médio (BRASIL, 2002a, p.120) o conceito de tema estruturador pode ser considerado como: "[...] campo de interesse com organização própria em termos de linguagens, conceitos, procedimentos e especialmente, objetos de estudo".

${ }^{20}$ Segundo Magalhães e Lima (2013, p.2): “[...] a estatística descritiva pode ser definida como um conjunto de técnicas destinadas a descrever e resumir os dados, a fim de que possamos tirar conclusões a respeito de características de interesse." 
- gráficos e tabelas - e a determinação de algumas das medidas de posição - médias, mediana e moda - e dispersão - amplitude, variância e desvio padrão.

Entendemos que o objetivo principal quando da realização de uma Análise Exploratória de Dados é tornar evidente certas características do conjunto de dados, mas que até então não eram passíveis de serem conhecidas, principalmente em virtude da forma pela qual os dados se apresentam logo após a sua coleta. Cada tipo de representação deve carregar consigo alguma(s) característica(s) inerente(s) do conjunto de dados, e aí reside exatamente sua importância.

Nesse sentido, o estudo das mais diversas representações pode nos possibilitar uma visão tanto mais ampla quanto detalhada a respeito do conjunto de dados, sobretudo, porque determinados aspectos deste e que acabam não sendo evidenciados em certa representação, poderão vir a ser em outra.

Entretanto, o fato do seu ensino estar submetido à disciplina de Matemática poderá desencadear problemas em alguns momentos, pois em diversos casos os professores acabam por abordá-los de um modo excessivamente formal e em outros casos, temos também a questão da supressão dos conteúdos da análise exploratória de dados e também das medidas resumo por parte dos professores de Matemática (BATANERO, 2001).

Porém, entendemos que o ensino-aprendizagem dos conteúdos da Estatística são de suma importância para uma formação plena do estudante, no que concordamos com Lopes (2008, p.60): “Tais assuntos são tão importantes no currículo de matemática da educação básica quanto o estudo da geometria, da álgebra ou da aritmética".

Caso o desenvolvimento dos conteúdos da análise exploratória de dados venha a ser suprimido na escola básica por uma escolha arbitrária do professor, Batanero (2001) sinaliza que pode-se estar deixando de lado uma ótima oportunidade de trabalhar com temas de interesse dos estudantes, além do que para o desenvolvimento dos conteúdos não é necessário um instrumental matemático sofisticado, aliás, até mesmo aqueles alunos que encontram dificuldades com determinados assuntos da Matemática poderiam caminhar adequadamente neste tema ${ }^{21}$, o que poderá se configurar como um fator motivacional para tais estudantes.

Cabe destacar também que pela possibilidade de se realizar distintas representações de um mesmo conjunto de dados, tal tema poderá não somente contribuir para a compreensão dos conceitos estatísticos que estão sendo trabalhados, mas também para o fortalecimento de

\footnotetext{
${ }^{21}$ As pesquisas que relatam investigações sobre o uso da metodologia de Projetos no ensino da Estatística no Ensino Médio têm apresentado resultados animadores nesse sentido, conforme podemos verificar em Santana (2011).
} 
alguns dos conceitos matemáticos que são evocados quando da construção dessas representações, por exemplo: porcentagem, proporções e áreas.

As medidas resumo sugeridas nos PCN+ Ensino Médio (BRASIL, 2002a) são as seguintes: i) de posição: médias, mediana e moda, ii) de dispersão: variância e desvio padrão ${ }^{22}$.

Quando pretendemos obter a média ou mediana de um determinado conjunto de dados, temos por objetivo determinar um número que possa vir a ser representativo desse conjunto, um número tal que possa informar, revelar e carregar consigo características do todo, mas também das partes.

É importante destacar que nessa redução, o conjunto de dados é o objeto de estudo e não cada um dos dados em particular. E, justamente por se tratar de um resumo propriamente dito, perdemos algumas informações, seja tomando-se como ponto de partida a tabela de dados brutos ou a tabela de frequências ou até mesmo um histograma. Pode-se dizer de certo modo, que este é o "preço" que pagamos se pretendemos depreender alguma informação ou síntese da totalidade.

Já no caso da moda temos por finalidade identificar "tendências", no sentido de investigarmos sobre a existência ou não de algum valor da variável que apresenta a maior frequência.

Devemos ponderar também que tão somente o estudo das medidas de posição não é suficiente para que possamos obter conclusões consistentes a respeito do conjunto de dados, já que é preciso evidenciar também o modo como os dados estão distribuídos. Com efeito, pois pode ocorrer o caso de conjuntos de dados apresentarem a mesma média aritmética, ainda que eles possuam distribuições distintas.

De fato, pois considere $A_{i}$ o conjunto das notas (considere a nota mínima igual a zero, a nota máxima igual a dez e somente valores inteiros) das quatro provas consecutivas realizadas pelo estudante $i$ na disciplina $A$ e suponhamos $i=1,2,3$ e 4 . Seja também a nota final na disciplina $A$ a média aritmética das notas das quatro provas consecutivas realizadas pelo estudante $i$. Se $A_{1}=\{5 ; 5 ; 5 ; 5\}, A_{2}=\{7 ; 3 ; 3 ; 7\}, A_{3}=\{1 ; 9 ; 9 ; 1\}$ e $A_{4}=\{0 ; 0 ; 10 ; 10\}$, então, verifica-se que a nota final dos quatro estudantes é precisamente a mesma: igual a 5.

Entretanto, ao observarmos a distribuição das notas, evidenciamos que o desempenho dos estudantes ao longo da disciplina $A$ foram distintos, o que pode ser corroborado por meio de uma medida de dispersão que consideramos simples, no sentido dos cálculos necessários

\footnotetext{
${ }^{22}$ As definições das medidas de posição e dispersão de um conjunto de dados aqui consideradas são aquelas apresentadas no Capítulo 4 de Magalhães e Lima (2013).
} 
para sua obtenção: a amplitude ${ }^{23}$. Com efeito, pois podemos notar que as respectivas amplitudes de cada um dos conjuntos de dados observados são as seguintes: 0, 4, 8 e 10.

Nesse sentido, verifica-se que o estudante $l$ foi extremamente regular em seu desempenho nas provas, de modo que sua nota manteve-se constante e igual a 5 , portanto, a amplitude observada foi mínima. Por outro lado, o estudante 4 apresentou uma mudança brusca de desempenho, de duas notas iniciais iguais a zero, para duas notas finais iguais a dez, fazendo assim com que a amplitude observada tenha sido máxima.

Note que, essa informação que também é importante a respeito do desempenho dos quatro estudantes nessa disciplina não foi captada pela média aritmética, portanto, torna-se apropriado torná-la evidente, o que é passível de ser realizado através das medidas de dispersão. As medidas de dispersão são fundamentais no estudo da distribuição de um conjunto de dados, mais ainda, entendemos que elas são tão importantes quanto as medidas de posição.

Aliás, o conceito de variabilidade é central na Estatística, conforme destacam Garfield e Ben-Zvi $(2005)^{24}$ e, segundo Franklin et al. (2007, p.6) o principal objetivo do ensino-aprendizagem da Estatística na Educação Básica deveria ser o de auxiliar os estudantes a desenvolver a capacidade de perceber e lidar com a variabilidade que se faz presente em qualquer conjunto de dados.

Nos PCN+ Ensino Médio (BRASIL, 2002a) faz-se menção somente à variância e o desvio padrão e nem a amplitude nem o intervalo interquartil estão contemplados em tal orientação. Entendemos que isso possa vir a se configurar como uma limitação quando do estudo da distribuição do conjunto de dados, pois a variância e o desvio padrão são medidas de dispersão que estão associadas à média aritmética.

Nessa linha de raciocínio, podemos supor que quando da abordagem das medidas de posição dê-se ênfase às médias - aritmética e ponderada - em detrimento da mediana e da moda, já que quando do estudo das medidas de dispersão, as únicas a serem sugeridas para estudo serão à variância e o desvio padrão.

O ensino-aprendizagem tanto da análise exploratória de dados quanto das medidas resumo tem por finalidade auxiliar o estudante no desenvolvimento da sua capacidade de organização e representação adequada de um conjunto de dados, pois lhe possibilitará extrair informações de interesse e, portanto, suas tomadas de decisões poderão ser realizadas de uma

\footnotetext{
${ }^{23}$ A amplitude de um conjunto de dados numéricos é a diferença entre o maior e o menor valor observado na amostra. Caso os valores observados sejam todos iguais então a amplitude é igual zero.

24 "Variability is at the heart of statistics and is the fundamental component of statistical thinking (Pfannkuch, 1997; Pfannkuch; Wild, 2004; Shaughnessy, 1997)”. (GARFIELD; BEN-ZVI, 2005, p.92)
} 
maneira mais científica, dispondo assim de conceitos estatísticos que poderão propiciá-lo um comportamento mais crítico perante os dados e informações que lhes são apresentados.

\subsubsection{As dificuldades na aprendizagem da Estatística}

Direcionaremos nossas reflexões e discussões para as dificuldades de aprendizagem relacionadas aos seguintes temas: leitura e interpretação de gráficos estatísticos e medidas de posição.

Entretanto, estamos cientes que tal escolha de modo algum esgota a lista de dificuldades que possam surgir no processo de aprendizagem da Estatística no Ensino Médio. Tal opção justifica-se pelo fato da leitura e interpretação de gráficos estatísticos e as medidas de posição serem conteúdos os quais os estudantes já desenvolvem seus primeiros estudos ainda no Ensino Fundamental, mesmo que de uma forma menos sistemática se comparada ao modo como tais conteúdos são trabalhados no Ensino Médio.

A necessidade de leitura e interpretação de gráficos estatísticos se faz presente em diversas situações do nosso cotidiano. Esse contato massivo que temos com esses gráficos, deve-se principalmente pelo fato dos meios de comunicação em massa os utilizarem em larga escala, ainda que às vezes os apresentem com equívocos, para a divulgação de informações que necessitam ser apresentadas de forma clara e concisa, mas que também sejam passíveis de uma rápida identificação por quem as recebe sem que se faça necessário um conhecimento específico sobre o tema.

Podemos até dizer que a atividade de leitura e interpretação de gráficos estatísticos é familiar aos estudantes do Ensino Fundamental II e Médio. No entanto, familiaridade não pode ser confundida com facilidade, conforme discutiremos adiante.

Em uma pesquisa realizada com estudantes portugueses do Ensino Fundamental, Fernandes e Morais (2011) tinham por objetivo verificar o nível de compreensão que os estudantes apresentavam em relação à leitura e interpretação de gráficos estatísticos. Para tal, aplicaram três atividades de resolução de problemas envolvendo respectivamente três tipos de gráficos: de barras simples, circular e de linhas. Para cada atividade, foram apresentados entre 3 e 4 itens, cada qual exigindo do estudante um certo nível de compreensão sobre o gráfico apresentado. 
A partir das respostas fornecidas, os autores procuraram classificá-las segundo os níveis de compreensão propostos por Curcio (1989)25: "ler os dados", "ler entre os dados" e "ler além dos dados"26.

O nível "ler os dados" pode ser entendido como aquele que faz referência aos conhecimentos que precisamos acessar quando da leitura inicial de um gráfico estatístico, ou seja, associado a uma leitura literal desse gráfico.

O nível "ler entre os dados" está situado em uma posição intermediária. Após um primeiro contato com o gráfico em questão, teríamos então a necessidade de estabelecer relações entre os dados apresentados para atribuir-lhes significado. Nessa etapa já se fazem necessários o acesso a conhecimentos matemáticos para a realização de tal tarefa.

O nível "ler além dos dados" é o mais sofisticado. Neste caso, o leitor deverá possuir além dos conhecimentos matemáticos, outros conhecimentos prévios do contexto ao qual os dados fazem referência. Dispondo desses conhecimentos, ele seria supostamente capaz de avaliar criticamente as informações apresentadas, bem como em alguns casos identificar tendências ou realizar previsões.

Com base nas respostas obtidas, os pesquisadores verificaram que os estudantes apresentaram em média um bom desempenho nos itens que remetiam ao nível de compreensão "ler os dados" (68\% de respostas corretas), ao passo que nos itens relacionados aos níveis "ler entre os dados" e "ler além dos dados" eles apresentaram em média, baixos desempenhos (respectivamente $24 \%$ e $33 \%$ de respostas corretas).

Além disso, verificou-se também que além do tipo de nível de compreensão o qual o item faz referência, o tipo de gráfico que ele está relacionado parece configurar-se como uma variável importante no processo de resolução de problemas associados à leitura e interpretação de gráficos, já que dentre os itens que faziam referência ao nível "ler os dados", os estudantes obtiveram desempenhos muito melhores naqueles associados aos gráficos de barras simples e circular (respectivamente $90 \%$ e $96 \%$ de respostas corretas) se comparado ao gráfico de linhas (19\% de respostas corretas).

Na conclusão da pesquisa, Fernandes e Morais (2011) pontuam também dois fatores que provavelmente podem estar associados aos erros cometidos pelos estudantes durante a resolução dos problemas: a lacuna de conhecimentos matemáticos necessários, a utilização

\footnotetext{
${ }^{25}$ Curcio (1989, apud FERNANDES; MORAIS, 2011).

${ }^{26}$ A caracterização em detalhes de cada um dos níveis apresentados pode ser verificada em Fernandes e Morais (2011, pp.97-98).
} 
generalizada e até de certo modo mecânica da regra de três simples e um conhecimento geral insuficiente para uma compreensão adequada do contexto no qual os gráficos estão situados.

Desse modo, acreditamos que os resultados apresentados por essa pesquisa (FERNANDES; MORAIS, 2011) tornam evidentes algumas das dificuldades inerentes à leitura e interpretação de gráficos estatísticos por parte dos estudantes e que não podem ser desconsideradas pelo professor, pois é provável que elas ainda não tenham sido superadas quando do ingresso dos estudantes no Ensino Médio.

Prosseguindo com as dificuldades de aprendizagem dos estudantes nos conteúdos de Estatística do Ensino Médio, discutiremos agora aquelas que dizem respeito às medidas de posição, pois conforme algumas pesquisas destacam, este é um assunto que está longe de ser facilmente compreendido pelos estudantes ${ }^{27}$.

Primeiramente, entendemos ser apropriado destacar que o desenvolvimento da compreensão do significado das medidas de posição por parte dos estudantes não será passível de ser alcançado, se nas atividades de ensino por eles vivenciadas o foco estiver situado exclusivamente nos aspectos computacionais relativos a tais medidas, ou seja, tarefas voltadas tão somente para o cálculo de médias, mediana e moda de um conjunto de dados não serão suficientes para a aquisição desses conceitos.

No caso da média aritmética, Gitirana et al. (2010, p.105) ressaltam que: "Estudos (Magina et al. 2008; Strauss e Bichler, 1998) mostraram que a maior parte dos sujeitos (alunos) conhece o algoritmo de cálculo da média aritmética, porém, apresenta dificuldades na utilização de algumas de suas propriedades, como também na interpretação do valor encontrado para a média".

Cabe destacar também que as dificuldades apresentadas pelos estudantes com respeito às medidas de posição, refletem em algum nível a própria complexidade conceitual dessas medidas (BATANERO, 2001, p.70), além disso, tais medidas não estão simplesmente subordinadas às fórmulas ou técnicas com os quais pudemos determiná-las, mas também a um leque de problemas e situações associadas, suas possíveis representações, bem como suas propriedades matemáticas e estatísticas.

No que diz respeito à média aritmética, que por definição, para variáveis quantitativas, é o quociente entre a soma dos valores observados e a quantidade de observações, podemos pontuar que:

\footnotetext{
${ }^{27}$ Batanero (2000), Cobo e Díaz (2003), Batanero, Merino e Díaz (2003), Cobo e Batanero (2004), Mayén, Díaz e Batanero (2009) e Gitirana et al. (2010).
} 
i) o cálculo das médias depende do modo como os dados são apresentados, ou seja, ainda que exista uma definição precisa para a média aritmética de um conjunto de dados baseada nos dados brutos, nem sempre e até mesmo dificilmente teremos acesso a estes dados, portanto, caso o conjunto de dados se apresente por meio de uma tabela de frequências, o itinerário a ser percorrido será diferente daquele no qual se tivéssemos acesso a todos os dados;

ii) a média aritmética é maior ou igual ao menor valor observado e menor ou igual ao maior valor observado;

iii) há que considerar valores nulos e negativos no cálculo da média aritmética;

iv) todos os valores do conjunto de dados são necessários para o cálculo da média;

v) a média aritmética é afetada pela presença de outliers ${ }^{28}$ no conjunto de dados, portanto, pode ocorrer da média aritmética não ser de fato um valor representativo desse conjunto;

vi) acrescentando-se um valor nulo a um conjunto de dados, a média aritmética desse novo conjunto é quase sempre distinta daquela associada ao conjunto de dados inicial ${ }^{29}$;

vii) a soma das diferenças entre cada um dos valores do conjunto de dados e a média aritmética é zero.

Segundo Cobo e Batanero (2004) algumas das dificuldades dos estudantes na resolução de problemas envolvendo as médias situam-se exatamente em uma interpretação equivocada destas propriedades ou até mesmo um desconhecimento de tais propriedades.

No tocante à mediana, que por definição, para variáveis quantitativas, é o valor central do conjunto de dados ordenados, destacamos que:

i) a técnica para a obtenção da mediana de um conjunto de dados depende do modo como ele está representado, por exemplo, o método para obtê-la através dos dados brutos é distinto daquele quando temos acesso apenas à tabela de frequências e que, por sua vez, também é distinto, caso estejamos lidando com o histograma;

${ }^{28}$ Segundo Magalhães e Lima outliers são:

[...] observações que podem ser atípicas para o fenômeno que gera os dados [...] Esses dados devem ser investigados com maior cuidado pois muitas vezes devem-se a erros de digitação ou de registro dos valores quando se realiza a coleta dos dados. Entretanto, vale notar que para distribuições assimétricas é comum o aparecimento de valores extremos. (MAGALHÃES; LIMA, 2013, p.21)

\footnotetext{
${ }^{29}$ Note que, se um conjunto de dados apresenta apenas valores nulos então sua média aritmética é zero, pois a soma dos valores observados é zero. Assim, acrescentando-se ao conjunto inicial um novo dado cujo valor é nulo então a soma dos valores observados permanece igual a zero e, portanto, a média aritmética desse novo conjunto de dados também é igual a zero.
} 
ii) se tivermos acesso aos dados brutos, há que se considerar para a obtenção da mediana não somente a quantidade de dados (par ou ímpar), mas também deve-se realizar previamente a ordenação destes dados;

iii) a mediana não é afetada pela presença de outliers no conjunto de dados (ela é dita uma estatística robusta), portanto, pode ser considerada como uma medida representativa desse conjunto, independentemente da presença ou não de valores atípicos;

iv) a mediana é maior ou igual ao menor valor observado e menor ou igual ao maior valor observado;

v) ao acrescentarmos um valor nulo ao conjunto de dados quase sempre a mediana desse novo conjunto de dados é diferente daquela associada ao conjunto de dados inicial ${ }^{30}$;

No caso da mediana, de forma semelhante ao que destacamos para a média, algumas das dificuldades dos estudantes também estão situadas em uma compreensão inadequada ou até mesmo no desconhecimento das propriedades matemáticas e estatísticas dessa medida.

Mayén, Díaz e Batanero (2009) conduziram uma pesquisa com estudantes mexicanos com idades entre 14 e 15 anos e também entre 17 e 18, com o intuito de identificar as concepções que os estudantes possuíam a respeito do conceito de mediana.

Por meio das respostas dadas pelos estudantes a um questionário elaborado e fornecido pelas autoras, foram identificados equívocos conceituais, dentre os quais podemos destacar a dificuldade em compreender a definição de mediana, pois concebe a mediana como o valor central no conjunto de dados sem considerar a sua ordenação e a confusão entre a mediana e a média aritmética, ou seja, quando solicitado para determinar a mediana de um conjunto de dados, aplica o algoritmo para a obtenção da média, mas acaba por denominá-la mediana.

Com respeito à moda, que por definição, para variáveis quantitativas ou qualitativas, é o valor da variável que apresenta a maior frequência, temos que:

i) a obtenção da moda de um conjunto de dados, assim como nos casos das médias e da mediana, depende do modo como os dados estão representados;

ii) é possível que um conjunto de dados não possua moda (distribuição amodal) ou que ele possua uma (distribuição unimodal) ou duas (distribuição bimodal) ou até mesmo mais do que duas (distribuição multimodal);

iii) a moda de um conjunto de dados - quando ela existe - é um elemento pertencente ao conjunto de dados ao qual ela faz referência.

\footnotetext{
${ }^{30}$ Observe que se o conjunto de dados for constituído apenas por valores nulos então sua mediana é zero e acrescentando-se um novo dado cujo valor é nulo então a mediana do conjunto permanece igual a zero.
} 
Ainda que de maneira hipotética, acreditamos que uma das dificuldades no aprendizado da moda, mais precisamente no que se refere à sua obtenção, possa estar diretamente relacionada à leitura e interpretação de gráficos e tabelas, pois, se dispomos, por exemplo, de um histograma, gráfico de setores ou gráfico de barras simples, a determinação da moda estará vinculada a nossa capacidade de "ler entre os dados", segundo a definição dada em Curcio (1989, apud Fernandes e Morais, 2011).

Enquanto que a média aritmética e a mediana de um conjunto de dados sempre existem, pode ocorrer de um conjunto de dados não possuir moda ou possuir uma, duas ou até mesmo mais do que duas. No contexto das medidas de posição a moda é a única que possui tal peculiaridade, o que pode vir a se configurar como um fator de dificuldade para o seu ensino-aprendizagem.

\subsection{A utilização das Tecnologias de Informação e Comunicação (TIC) no ensino-aprendizagem da Estatística no Ensino Médio}

Chance et al. (2007, p.1, tradução nossa) afirmam que "é difícil imaginar nos dias de hoje o ensino da Estatística sem a utilização da tecnologia" ${ }^{31}$. No que concordamos com os autores, sobretudo porque a tecnologia tem mudado a própria Estatística. De fato, com o aumento da capacidade de processamento dos computadores tornou-se possível o tratamento estatístico de uma grande quantidade de dados, cálculos de probabilidades, a aplicação de metodologias mais complexas, entre outros aspectos, o que vem alterando o modo como a própria análise de dados é realizada.

Assim, a compreensão dos resultados e gráficos obtidos a partir destes programas de computador torna-se o ponto central quando da manipulação e tratamento de dados. Isto posto, é razoável esperarmos que tal mudança tenha implicações também no ensino-aprendizagem da Estatística no Ensino Médio.

4.3.1 Uma primeira ideia de utilização das TIC no ensino-aprendizagem da Estatística no Ensino Médio: o caso das planilhas eletrônicas

Ben-Zvi (2000, p.142) destaca que umas das potencialidades oferecidas pelas TIC no ensino-aprendizagem da Estatística se refere à capacidade destas tecnologias de permitirem a

31 "It is hard to imagine teaching statistics today without using some form of technology". 
visualização de distintas representações de um conjunto de dados, bem como a possibilidade de uma rápida transição entre essas representações.

Ao inserirmos dados em uma planilha eletrônica, geralmente podemos solicitar a representação destes em um histograma ou gráfico de barras ou gráfico de setores, dependendo do tipo de variável considerada. Além disso, é possível que o programa forneça também as medidas de posição e dispersão do conjunto de dados.

Nesse sentido, o estudante teria a possibilidade de simultaneamente lidar com a tabela de dados brutos, algum outro tipo de representação gráfica, bem como as medidas de posição e dispersão do conjunto, ou seja, praticamente todos os assuntos de Estatística Descritiva do Ensino Médio poderiam ser contemplados em uma mesma atividade.

Cabe notar também que os conjuntos de dados a serem utilizados nas situações de ensino-aprendizagem com o uso de software ou planilhas eletrônicas são de fundamental importância. E assim, surge a possibilidade de se trabalhar com dados reais, sejam eles coletados pelos estudantes na realização de alguma pesquisa estatística ou oriundos de banco de dados externos.

Pode ocorrer até mesmo que os dados a serem utilizados estejam relacionados a algum tema que está sendo estudado em Geografia, Sociologia ou Biologia, o que poderá despertar o interesse dos estudantes, bem como poderá contribuir para que eles possam perceber a importância e relevância da Estatística.

Deste modo, caberá aos estudantes por meio da mediação do professor, a tarefa de construção, leitura, interpretação e discussão dos resultados apresentados, ou seja, o que tais gráficos e medidas nos informam acerca do conjunto de dados. Tais possibilidades de aprendizagem em nosso ver mostram-se a princípio promissoras e encorajadoras.

Por outro lado, entendemos que cautela e planejamento são fundamentais, sobretudo, porque devemos entender que as TIC possuem suas limitações, ainda que elas ofereçam novas possibilidades de ensino-aprendizagem.

Podem ocorrer eventuais erros técnicos ou conceituais no uso dos programas. Pode acontecer que informações importantes estarem implícitas, mas que precisam ser especificadas quando da representação gráfica do conjunto de dados, por exemplo, em um histograma em que no eixo vertical não está discriminado se está utilizando-se a frequência relativa, frequência absoluta ou densidade de frequência. Já no que se refere ao eixo horizontal, pode ocorrer de não estar explícito quais são os intervalos de classe adotados.

Com isso, queremos salientar que as situações de ensino-aprendizagem com o uso das TIC, no caso das planilhas eletrônicas, possuem potencialidades e limitações, assim como o 
ensino tradicional também as oferece ainda que elas possam se apresentar de formas distintas em cada um dos casos. Outro ponto que poderá ser limitante da utilização de software do tipo planilha eletrônica reside na sua gratuidade ou não ${ }^{32}$.

De fato, há que se considerar, por exemplo, que o modelo predominante de TIC nas escolas públicas ainda é o do laboratório de informática, portanto, os computadores deverão possuir a licença de uso de tal software, além do que, provavelmente uma parte das atividades será realizada pelo estudante em sua casa, seja devido ao tempo de aula ou até mesmo pelo seu próprio interesse.

Ainda que o uso das planilhas eletrônicas possa ser aquele que inicialmente temos em mente quando pensamos no ensino-aprendizagem da Estatística, justamente por permitir a organização, tratamento de dados e análise de dados, tal como um estatístico a utilizaria provavelmente, há que se ter em mente que outros recursos oferecidos pelas TIC também podem vir a ser apropriados para o ensino-aprendizagem da Estatística no Ensino Médio.

4.3.2 Uma segunda ideia de utilização das TIC no ensino-aprendizagem da Estatística no Ensino Médio: o caso dos recursos educacionais disponíveis na internet

Conforme pode ser visto em Tishkovskaya e Lancaster (2012) e também em Chance et al. (2007), já se faz existente um grande número de vídeos, textos, software, entre outros recursos disponíveis na internet e que podem ser utilizados no ensino-aprendizagem de Probabilidade e Estatística no Ensino Médio. Alguns desses software são livres e até mesmo gratuitos para o usuário. Alguns deles podem ser baixados e depois utilizados no computador sem a necessidade de acessar a internet, já outros, só podem ser utilizados se conectados a ela.

Para uma leitura mais rica e em detalhes sobre os vários tipos de recursos que encontram aporte nas TIC e que podem ser utilizados para o ensino-aprendizagem da Estatística no Ensino Médio remetemos às referências apresentadas no início do parágrafo anterior, bem como a Godino et al. (2003) e Reyes (2013).

No próximo capítulo, iremos nos deter especificamente sobre um recurso educacional concebido para o ensino-aprendizagem da Estatística no Ensino Médio e cuja licença de uso

\footnotetext{
${ }^{32}$ Um software livre e gratuito para o usuário que temos conhecimento e que já utilizamos por diversas vezes na funcionalidade de planilha eletrônica é o Geogebra (já citado no Capítulo 3). Ainda que ela seja geralmente utilizado no ensino-aprendizagem de Geometria e Álgebra, na disposição "Tabelas e Gráficos" ele possibilita a análise descritiva de dados, fornecendo diversas representações dos dados, tais como, gráfico de pontos, histograma, box-plot etc., bem como apresenta algumas das suas medidas de posição e dispersão. Além disso, quando os dados de entrada são alterados, automaticamente as suas representações e medidas são modificadas de modo a se fazerem condizentes com o novo conjunto de dados, como que possibilitando uma "Estatística Dinâmica" e no que acreditamos ser uma característica interessante desta ferramenta.
} 
lhe confere o estatuto de Recurso Educacional Aberto (REA). Ele será o objeto da nossa análise crítica. 


\title{
5 Critérios e a análise crítica de um Recurso Educacional Aberto (REA)
}

\begin{abstract}
O conhecimento é um bem imaterial que cresce quanto mais livre estiver. Ele não sofre escassez, que é típica de bens materiais. Ao contrário, quanto mais pessoas tiverem acesso a um conjunto de conhecimentos, mais ele poderá crescer.
\end{abstract}

Sérgio Amadeu da Silveira - sociólogo

\subsection{Repositórios de recursos educacionais digitais ${ }^{33}$ para o ensino- -aprendizagem de Probabilidade e Estatística}

Nesta seção, iremos brevemente apresentar três repositórios de recursos educacionais digitais para o ensino-aprendizagem de Probabilidade e Estatística.

\subsubsection{Coleção Matemática Multimídia (M3) ${ }^{34}$}

O repositório M3 é um portal com recursos educacionais digitais sobre os conteúdos de Matemática de Ensino Médio, desenvolvido por pesquisadores e estudantes da Universidade Estadual de Campinas (UNICAMP), bem como por pesquisadores colaboradores de outras instituições. O projeto contou com financiamento dos seguintes órgãos do governo federal: Fundo Nacional de Desenvolvimento da Educação (FNDE), Ministério da Ciência e Tecnologia (MCT) e Ministério da Educação (MEC).

A figura seguinte mostra o layout da página na data de acesso.

\footnotetext{
${ }^{33}$ Recursos educacionais digitais serão aqui considerados como vídeos, áudios, software etc. disponibilizados em formato digital e que podem auxiliar ou oferecer suporte ao ensino-aprendizagem em qualquer nível de ensino.

${ }^{34}$ Disponível em: <http://m3.ime.unicamp.br/>. Acesso em: 19 jan. 2016.
} 


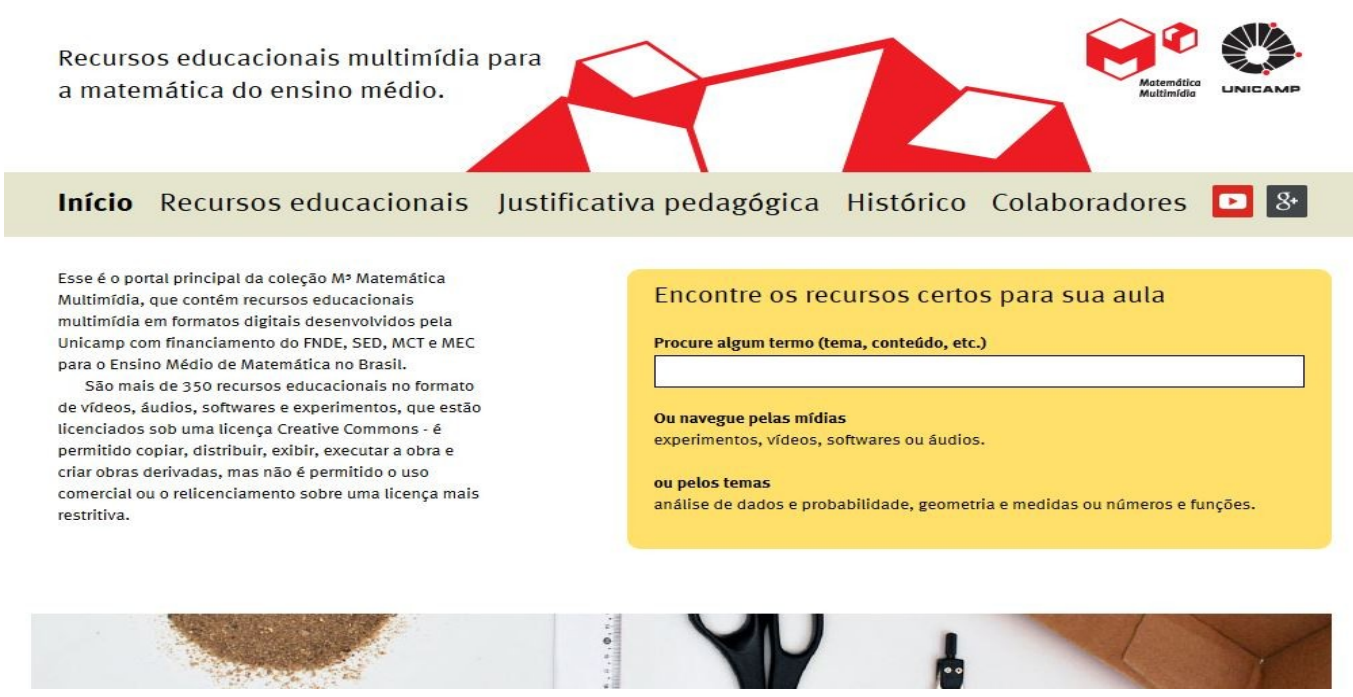

Figura 1 - Página inicial do repositório M3

Segundo consta na página inicial do repositório "são mais de 350 recursos educacionais no formato de vídeos, áudios, softwares e experimentos”.

Um ponto que consideramos de destaque, além da quantidade de recursos, é que eles estão disponibilizados sob uma licença do tipo Creative Commons ${ }^{35}$ na qual o usuário tem permissão para copiar, distribuir, exibir e executar a obra, bem como criar obras derivadas desde que seja atribuída a devida autoria da obra. Portanto, tais recursos podem ser considerados REA. Entretanto, não é permitido o uso comercial das obras, tampouco a sua distribuição por meio de uma licença mais restritiva.

No que se refere a recursos concebidos especificamente para o ensino-aprendizagem de Probabilidade e Estatística, conforme pode ser visto no Apêndice A temos um total de 57 recursos, cobrindo não somente conteúdos que tradicionalmente são desenvolvidos no Ensino Médio, mas também alguns do Ensino Superior, tais como amostragem, correlação, função gaussiana e cadeias de Markov.

\footnotetext{
${ }^{35}$ É um conjunto de licenças flexíveis para obras intelectuais. Neste tipo licença de uso, o autor pode escolher o que será permitido ou não ao usuário realizar com sua obra, diferentemente de uma licença do tipo copyright. Mais informações podem ser encontradas em: $<$ https://creativecommons.org/>.
} 
5.1.2 Conteúdos digitais para o ensino e aprendizagem de Matemática e Estatística $(\mathrm{CDME})^{36}$

O portal CDME foi elaborado por pesquisadores e estudantes da Universidade Federal Fluminense (UFF) e tal como o repositório M3, ele também contou com financiamento público (FNDE, MCT e MEC). Ele contém recursos educacionais digitais para o ensino e aprendizagem de Matemática e Estatística no Ensino Médio. A figura seguinte mostra o layout da página na data de acesso.

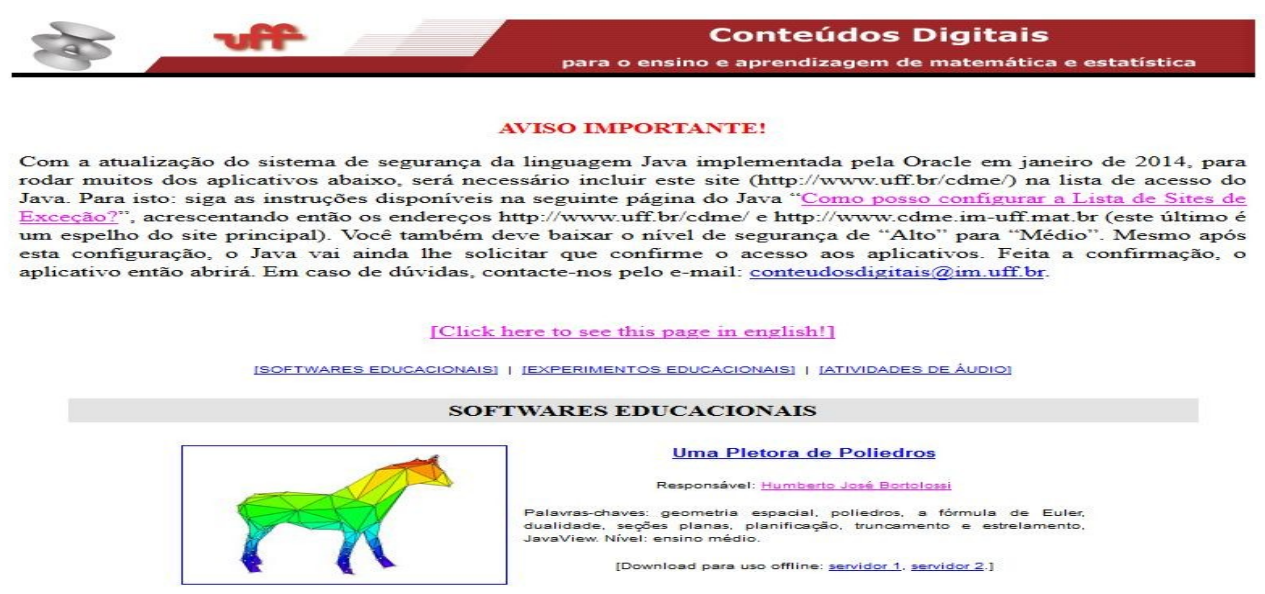

Figura 2 - Página inicial do repositório CDME

Os recursos disponibilizados estão submetidos a mesma licença Creative Commons ${ }^{37}$ tal como os recursos do repositório M3. Deste modo, os recursos do CDME podem ser concebidos como REA. Conforme descrito na página inicial do repositório, os materiais lá disponibilizados são "softwares educacionais, experimentos educacionais e atividades de áudio".

De nosso interesse para este trabalho, são aqueles recursos que dizem respeito especificamente ao ensino-aprendizagem da Probabilidade e Estatística e conforme pode ser conferido no Apêndice A, eles correspondem um total de 14 recursos. Além disso, eles cobrem praticamente todos os conteúdos de Probabilidade e Estatística que comumente são desenvolvidos no Ensino Médio e alguns que geralmente são tratados apenas no Ensino Superior, por exemplo, quartis e o gráfico de caixa ou box-plot.

\footnotetext{
${ }^{36}$ Disponível em: <http://www.uff.br/cdme/>. Acesso em: 19 jan. 2016.

${ }^{37}<$ http://creativecommons.org/licenses/by-nc-sa/2.5/br/>.
} 


\subsubsection{Atividades de Estatística (AtivEstat) ${ }^{38}$}

O portal AtivEstat foi desenvolvido por pesquisadores do Departamento de Estatística do Instituto de Matemática e Estatística da Universidade de São Paulo (IME-USP) em colaboração com estudantes deste instituto. O projeto contou com apoio financeiro da PróReitoria de Graduação (PRG) e da Pró-Reitoria de Cultura e Extensão Universitária (PRCEU) da Universidade de São Paulo (USP). A página inicial do AtivEstat é apresentada na figura a seguir, na data em que realizamos o acesso ao portal.

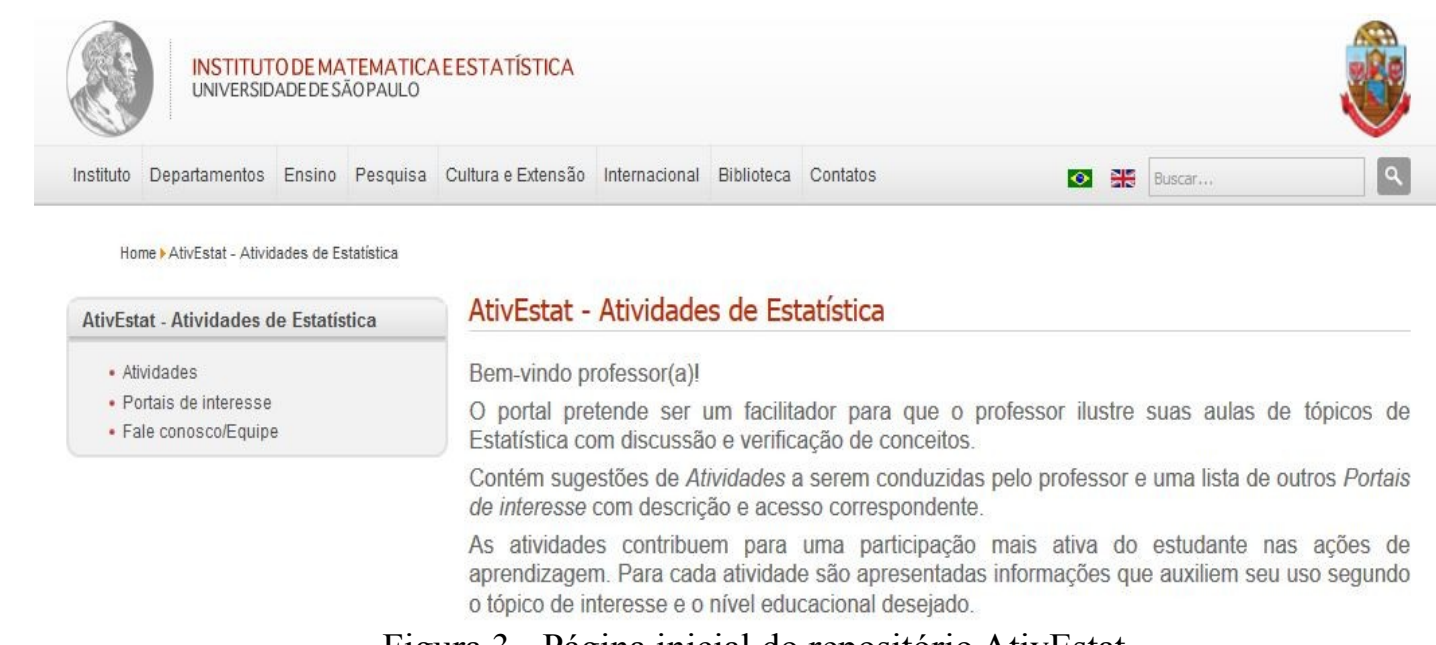

Figura 3 - Página inicial do repositório AtivEstat

No AtivEstat podem ser encontrados recursos educacionais digitais para o ensino-aprendizagem da Probabilidade e Estatística em todos os níveis. Dentre as atividades propostas, uma parte pertence a outros repositórios e a outra parte que são de autoria própria dos colaboradores do portal.

Conforme constatamos na data de acesso ao portal, as atividades lá apresentadas são dos seguintes tipos: sala de aula (12), miniaplicativos (21), planilhas (4), proposta de projetos (5) e filmes e vídeos (17). Assim, contabilizamos um total de 59 recursos.

No que se refere à licença de uso dos recursos, ela não está explicitada no portal, portanto, caberá ao usuário pesquisar a respeito da licença de uso de um determinado recurso quando existe a pretensão de utilizá-lo, atribuindo devidamente a autoria da obra e sua licença de uso.

\footnotetext{
${ }^{38}$ Disponível em: <http://www.ime.usp.br/ativestat>. Acesso em: 19 jan. 2016.
} 
Além de alocar os recursos educacionais digitais, o portal também serve como um guia, elencando para o usuário outros sites relacionados à Estatística, bem como, ao seu ensino. Para tal, basta que o usuário dirija-se até a seção "Portais de interesse".

\subsection{Critérios de análise}

Nesta seção, apresentamos os onze critérios que nortearão nossa análise crítica. Além das definições propriamente ditas, procuramos pontuar também as referências nas quais identificamos elementos teóricos que subsidiaram a elaboração de cada um dos critérios.

Os sete primeiros critérios de análise ( $\mathrm{C} 1$ até $\mathrm{C} 7)$ que serão apresentados foram extraídos quase que na íntegra de Diniz $(2015)^{39}$, que por sua vez considerou para a elaboração de tais critérios as contribuições oferecidas por Brasil (2015) e Reategui, Boff e Finco (2010). Inclusive optamos por manter a ordem e nomenclatura dos critérios adotada pelo autor no trabalho citado.

Os critérios C2 e C3 seguem na íntegra o que foi apresentado em Diniz (2015). Já os demais critérios trazem algumas poucas alterações no que se refere a algumas das palavras que lá são adotadas pelo autor. Faremos isso com a pretensão de adquirir um maior alcance para nossas considerações, bem como agregar elementos de outras referências estudadas que também abordam o tema.

Nos critérios C1 e C7 substituímos a palavra aluno por usuário. Já no critério C4 trocamos a palavra desenvolvedor por administrador. No critério C5 item ii), alteramos a palavra voltado por orientado. Neste mesmo critério, mas agora no item iii), optamos pela palavra direcionado em vez de voltado. Por fim, no critério C6 incluímos o trecho sons de leitura no início da apresentação dos exemplos de ferramentas de acessibilidade dados pelo autor.

Seguem abaixo os critérios:

C1. Guia didático: trata da oferta de orientações diversas para o professor e para o usuário, não somente no que se refere à utilização do recurso, mas também sugestões alternativas de uso, roteiro de atividades e instrumentos de avaliação.

\footnotetext{
${ }^{39}$ Trabalho apresentado no Grupo de Discussão n. 12 (Ensino de Probabilidade e Estatística) do XIX Encontro Brasileiro dos Estudantes de Pós-Graduação em Educação Matemática (EBRAPEM), realizado entre os dias 30 de outubro e 2 de novembro de 2015, na Universidade Federal de Juiz de Fora (UFJF).
} 
C2. Usabilidade: refere-se à manipulação propriamente dita do recurso considerando o seu público-alvo, ou seja, se ele requisita ou não do usuário uma extensa lista de conhecimentos instrumentais sobre o próprio recurso para a sua utilização.

C3. Estabilidade: neste critério procura-se discutir a respeito da estabilidade do recurso durante a sua execução, ou seja, o recurso será considerado estável se o usuário conseguir realizar todas as atividades que são anunciadas na apresentação do recurso, bem como no seu decorrer, sem que ocorram erros de funcionamento.

C4. Consistência do conteúdo: procura-se evidenciar a qualidade e consistência do conteúdo proposto pelo recurso, possibilitando assim a identificação e discussão de eventuais erros conceituais que se mostram evidentes ou não ao usuário no decorrer da sua utilização e, nesse sentido, torna-se pertinente discutir também sobre a existência ou não de um canal de comunicação entre o usuário e o(s) administrador(es), a fim de que o usuário possa reportar eventuais erros, contribuindo assim para o aprimoramento do recurso.

C5. Perspectiva epistemológica: trata-se da concepção de ensino-aprendizagem subjacente ao recurso, podendo ser adotada eventualmente as seguintes classificações que não são excludentes entre si:

i) comportamentalista: voltado para a instrução e com foco no ensino;

ii) construtivista: orientado para a construção do conhecimento e com foco na aprendizagem;

iii) sócio-interacionista: direcionado para a construção do conhecimento sendo considerada não somente a interação entre o usuário e o recurso, mas tão fundamental quanto é o meio social no qual ele está inserido. No caso de um estudante em uma escola, seus colegas de classe e professores, por exemplo, podem contribuir decisivamente em seu processo de construção do conhecimento.

C6. Ferramentas de acessibilidade: investiga-se sobre a existência de ferramentas que permitam a utilização do recurso por pessoas com necessidades especiais, bem como ferramentas que possibilitem a modificação e ajuste da interface do recurso de acordo com as necessidades do usuário mesmo que ele não seja portador de necessidades especiais. Por exemplo, sons de leitura, legenda e tradutor intérprete de Libras $^{40}$ para vídeos e possibilidade de: ampliação de imagens, modificação no tamanho e tipo da fonte, espaçamento entre as linhas, cor e contraste.

C7. Potencial didático: discute-se neste critério se o leque de conceitos e problemas que podem ser explorados com o recurso é amplo ou restrito, levando-se em consideração o conteúdo de ensino que o recurso pretende auxiliar o desenvolvimento. Além disso, pretende-

\footnotetext{
$\overline{{ }^{40} \text { Língua Brasileira de Sinais. }}$
} 
-se verificar se o recurso propicia ao usuário situações de aprendizagem que ampliam e potencializam aquelas que já são vivenciadas (ou que foram vivenciadas) por ele nos ambientes de aprendizagem tradicionais.

O próximo critério que apresentaremos é de nossa autoria e trata de aspectos que podem, em nosso ver, contribuir especificamente para o aprendizado de Probabilidade e Estatística na Educação Básica. Para a elaboração deste critério, consideramos como fundamentais as discussões que foram desenvolvidas nas seções 4.2.1 e 4.2.2:

C8. Manipulação de dados e representações ${ }^{41}$ : neste critério investiga-se sobre dois aspectos que, em nosso ver, podem favorecer o desenvolvimento construção, leitura e interpretação de gráficos, bem como o aprendizado das medidas de posição e dispersão:

i) se o recurso possibilita ao usuário variar a quantidade de dados a ser estudada, de modo que ele possa trabalhar com amostras de tamanhos variados, investigar suas possíveis implicações sobre as representações e também seu impacto sobre as medidas de posição e dispersão;

ii) se o recurso permite o usuário transitar entre as distintas representações, para que ele possa ter a liberdade de optar pela representação que lhe for conveniente e apropriada.

Os próximos dois critérios foram elaborados a partir das contribuições apresentadas em Kawachi (2014):

C9. Contribuição à cidadania: neste critério procura-se discutir se o recurso encontra-se isento de aspectos e informações que podem desencadear qualquer tipo de discriminação, seja ela de gênero, racial, socioeconômica, entre outras.

C10. Conexão com outros recursos: procura-se investigar se o recurso faz alusão a outros recursos educacionais, com preferência para os REA, que possam vir a antecipar e ampliar a sua proposta de trabalho, ou se ele sugere outro recurso que pode ser utilizado para trabalhar os mesmos conteúdos, entretanto, com uma abordagem distinta. A conexão com outros recursos poderá ser proveitosa em duas frentes:

i) para o estudante que pretende aprofundar seus estudos no tema desenvolvido e para aquele estudante que apresentou dificuldades com a abordagem proposta pelo recurso, tendo ele, portanto, uma outra oportunidade de aprendizagem do tema;

ii) para o professor que pretende ampliar a proposta do recurso, por meio da remixagem das obras, com a inclusão de atividades de sua autoria e para aquele outro professor que almeja rever os recursos em detalhes. Ele poderá ainda comparar os recursos através da identificação

\footnotetext{
${ }^{41}$ Eis alguns exemplos de representações dos dados: tabela de dados brutos, tabela de frequências, gráfico de pontos, gráfico de setores, histograma, entre outros. Cabe ressaltar que, os possíveis tipos de representações das informações dependem do tipo da variável que está sendo estudada.
} 
de seus pontos positivos e negativos, evidenciados por meio da sua experiência na utilização em sala de aula ou em seus estudos individuais.

O último critério foi elaborado a partir dos elementos teóricos trazidos em Amiel, Orey e West (2011), bem como aqueles discutidos em Silveira (2012):

C11. Licença de uso, abertura e formato técnico: neste critério procura-se evidenciar a importância da licença de uso a qual está submetida o recurso, bem como se ele foi construído através de software livre (aberto) ou proprietário (fechado) ${ }^{42}$.

Verifica-se ainda neste critério, a consonância entre a licença de uso e o tipo de software com que ele foi construído (aberto ou fechado), pois nos parece contraditório, por exemplo, um recurso cuja licença de uso lhe confira o estatuto de REA, mas que por outro lado, tenha sido construído por meio de um software proprietário, o que poderá dificultar ou impossibilitar o remix da obra.

\subsection{O recurso "Medidas do corpo: gráficos univariados" e sua análise crítica}

A análise crítica que realizaremos será desenvolvida por meio dos critérios apresentados na seção anterior. No entanto, tal análise será precedida por uma descrição detalhada do recurso. Faremos isso com o intuito de situar o leitor com respeito a sistemática do recurso, no que acreditamos ser um ponto fundamental para que o mesmo possa estar em condições de acompanhar a análise que desenvolveremos.

Ponderamos que a escolha do recurso em questão, em um primeiro momento, justifica-se pois: i) ele é voltado para o ensino-aprendizagem da Estatística no Ensino Médio, ii) ele é um REA e, iii) ele foi elaborado através de financiamento público.

No entanto, considerando a numerosa quantidade de recursos que satisfazem as condições citadas no parágrafo anterior (ver Apêndice A) e com o intuito de delimitar o

\footnotetext{
${ }^{42}$ Segundo Silveira:
}

O software é aberto quando seus programadores tornam disponível o texto que contém todas as instruções logicamente encadeadas que o compõe, em uma das linguagens de programação existentes. Esse texto é chamado código-fonte [...] $\mathrm{O}$ software fechado é distribuído somente com seu código executável; assim, apenas os computadores conseguem lê-lo. (SILVEIRA, 2015, p.75) 
recurso que tínhamos por pretensão analisar, adotamos os seguintes procedimentos metodológicos:

Etapa 1: realizamos um levantamento dos recursos disponíveis nos repositórios M3 e CDME que abordavam os conteúdos de Estatística que são recomendados a serem trabalhados no Ensino Médio de acordo com os PCN+ Ensino Médio (BRASIL, 2002a).

Etapa 2: decidimos analisar um único recurso e que este seria do tipo software pois, tal tipo de recurso nos possibilitaria uma análise mais abrangente se comparado, por exemplo a um vídeo e, além disso, já tínhamos conhecimento de algumas pesquisas que se debruçavam exatamente sobre a análise de software educacional.

Etapa 3: realizamos um novo levantamento nos repositórios M3 e CDME com o intuito de identificar um software que abordasse de forma mais abrangente possível os conteúdos de Estatística sugeridos para o Ensino Médio segundo os PCN+ Ensino Médio (BRASIL, 2002a) e que permitisse também o trabalho com dados reais coletados pelo usuário. Nesse sentido, identificamos o recurso "Medidas do corpo: gráficos univariados" do repositório M3 e verificamos que ele satisfazia as condições estabelecidas.

\subsubsection{Conhecendo o recurso}

O software "Medidas do corpo: gráficos univariados" 43 é um recurso voltado para o ensino-aprendizagem da Estatística no Ensino Médio e encontra-se disponibilizado no repositório M3. A página de apresentação do recurso é tal conforme a Figura 4.

\footnotetext{
${ }^{43}$ Disponível em: <http://m3.ime.unicamp.br/recursos/1233>. Acesso em: 19 jan. 2016.
} 


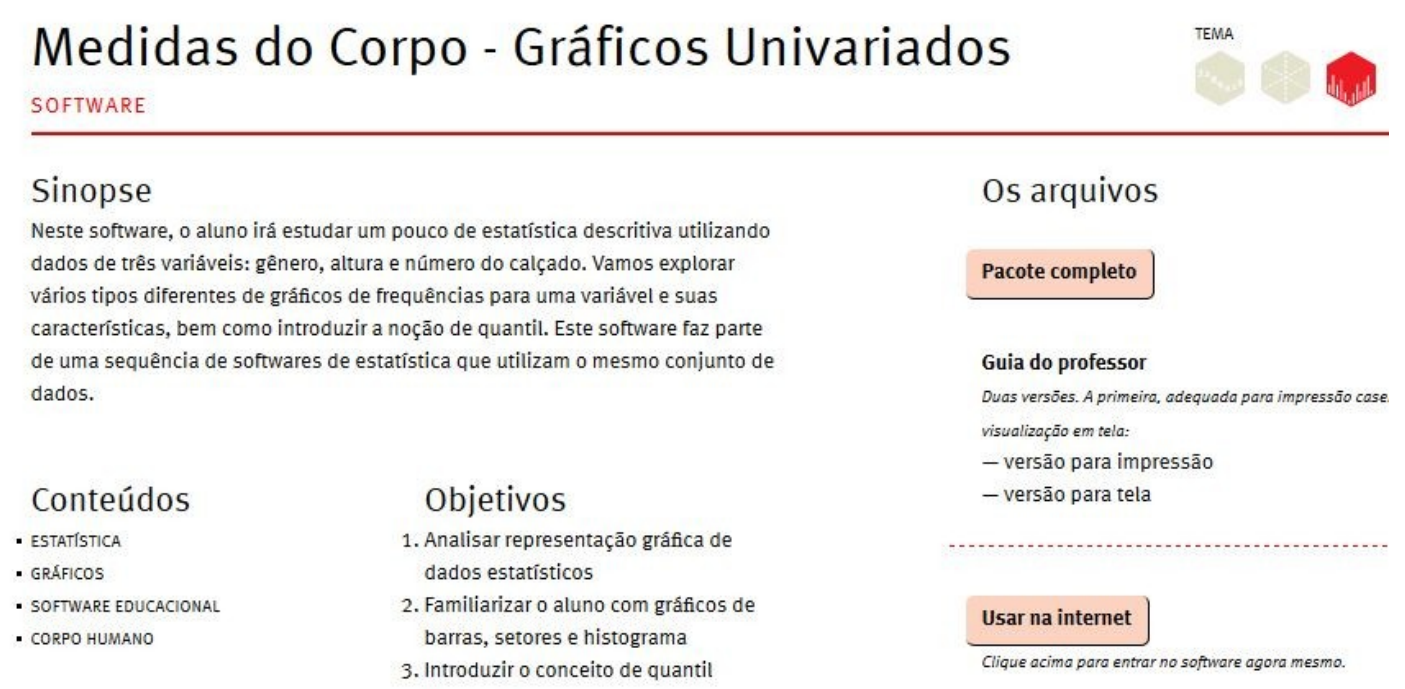

Figura 4 - Página de apresentação do recurso "Medidas do corpo: gráficos univariados"

A proposta do recurso, segundo descrito em sua sinopse é a de possibilitar ao aluno "estudar um pouco de estatística descritiva utilizando dados de três variáveis: gênero, altura e número do calçado" e ainda, "explorar vários tipos diferentes de gráficos de frequências para uma variável e suas características, bem como introduzir a noção de quantil”.

Conforme descrito na página de apresentação do software, ele "faz parte de uma sequência de softwares de estatística que utilizam o mesmo conjunto de dados". Para o desenvolvimento da proposta de trabalho trazida pelo recurso, considera-se a título de sugestão para o professor uma aula dupla.

Segundo consta na página de apresentação do recurso (Figura 4), os conteúdos que serão abordados são "Estatística, Gráficos, Software Educacional e Corpo Humano”.

Os objetivos específicos do recurso, apresentados em sua página inicial são:

1. Analisar representação gráfica,

2. Familiarizar o aluno com gráficos de barras, setores e histograma, e

3. Introduzir o conceito de quantil.

O recurso pode ser utilizado online ou offline, pois é permitido ao usuário o acesso e desenvolvimento das atividades através de um navegador de internet ou realizar o download do recurso e seus materiais complementares (no caso, o "Guia do Professor" tanto para visualização em tela, quanto para impressão) e utilizá-lo no computador, sem necessariamente ter acesso à internet.

A oferta das duas possibilidades de uso, online e offline, em nosso ver, configura-se como um atributo positivo e que poderá estimular a utilização do recurso em sala de aula ou no laboratório de informática, considerando-se principalmente o panorama das TIC nas 
escolas públicas que apresentamos e discutimos no capítulo 3, principalmente no que se refere as dificuldades de acesso à internet.

Prosseguindo com a apresentação do recurso, é informado que para que ele possa ser executado é necessário ter instalado no computador os seguintes programas: navegador de internet (Internet Explorer 7.0+ ou Firefox 3.0+), Java 1.6+ e Adobe Flash Player 9.0+.

Além disso, há um aviso na página inicial do recurso acerca de eventuais problemas de funcionamento em virtude de mudanças na política de segurança do Java, no que discutiremos de forma mais detalhada no critério Estabilidade.

Por outro lado, ainda que tais problemas de funcionamento possam vir a ocorrer, tais constatações poderão ser comunicadas aos administradores do repositório M3, por meio dos seguintes canais de comunicação: a publicação do comentário na página inicial do recurso ${ }^{44}$ ou o contato com o coordenador geral acadêmico do $\mathrm{M}^{45}$.

Acreditamos também que tais canais de comunicação podem possuir outra finalidade tão importante quanto a primeira já descrita: possibilitar aos professores apresentar seus relatos de experiência na utilização do recurso em sala de aula, ainda que no período em que realizamos a análise crítica do recurso (18 à 24 de janeiro de 2016) não observamos nenhum relato desse tipo por meio de tal ferramenta.

Com relação aos requisitos técnicos para a execução do recurso, bem como o aviso sobre eventuais erros de funcionamento, entendemos que tais aspectos não devem eventualmente desmotivar o professor a querer utilizá-lo com seus estudantes.

Nesse sentido torna-se fundamental que o professor junto com seus estudantes e até mesmo com o profissional responsável pelo laboratório de informática da escola possam antecipadamente verificar quais programas são necessários e daí configurar suas máquinas para que elas estejam em condições de executar o recurso. O importante é o professor compreender que não está desamparado para o enfrentamento de tais questões técnicas.

\footnotetext{
${ }^{44}$ Depende da aprovação dos moderadores do site.

${ }^{45}$ Prof. Dr. Samuel Rocha de Oliveira, docente do Instituto de Matemática, Estatística e Computação Científica da Universidade Estadual de Campinas (IMECC-UNICAMP).
} 


\subsubsection{Explorando o recurso}

Nesta seção faremos um tour de apresentação do recurso ${ }^{46}$. Faremos isso com o intuito de identificar os comandos necessários para desenvolvimento das atividades, bem como verificar o próprio desenvolvimento destas, ou seja, a sistemática do recurso. Além disso, esperamos propiciar ao leitor uma breve imersão no recurso, o que poderá contribuir para uma melhor compreensão acerca da análise crítica que realizaremos na sequência.

De início, após clicar no ícone Usar na internet na página de apresentação do recurso (Figura 4) o usuário é direcionado para uma página inicial do recurso (Figura 5). Nesta página, o usuário poderá obter informações, tais como, a Ficha técnica da unidade e a Ficha técnica do projeto.

Na Ficha técnica da unidade estão atribuídos os devidos créditos ao autor do recurso, bem como os responsáveis pelas ilustrações, revisão ortográfica entre outros. Já na Ficha técnica do projeto estão atribuídos os créditos aos responsáveis pelo projeto de elaboração do repositório M3, tais como, o coordenador geral, o coordenador de software, dentre outros.

Destacamos a descrição dos conteúdos: "Neste software, você irá estudar um pouco de estatística descritiva e explorar gráficos de frequências para uma variável”.

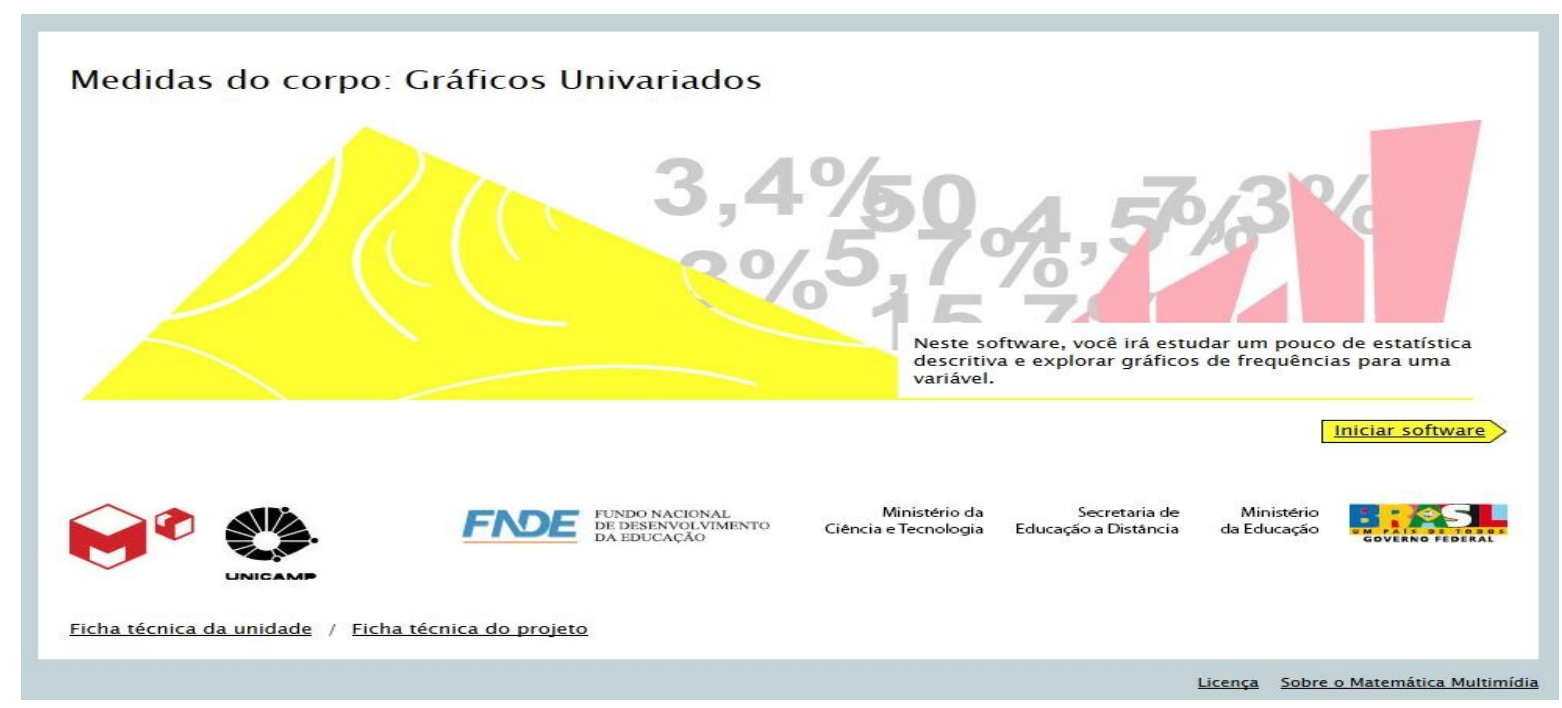

Figura 5 - Página inicial do recurso

Após clicar no botão Iniciar software na página inicial do recurso (Figura 5), o usuário segue então para uma página de introdução que contém um breve texto ressaltando a

\footnotetext{
${ }^{46}$ Exploraremos o recurso no seu modo online, através do navegador Mozilla Firefox versão 43.0.4.
} 
importância da utilização dos gráficos na representação dos dados, o que será estudado com o auxílio do software e os conteúdos de Estatística que serão abordados ao longo do recurso.

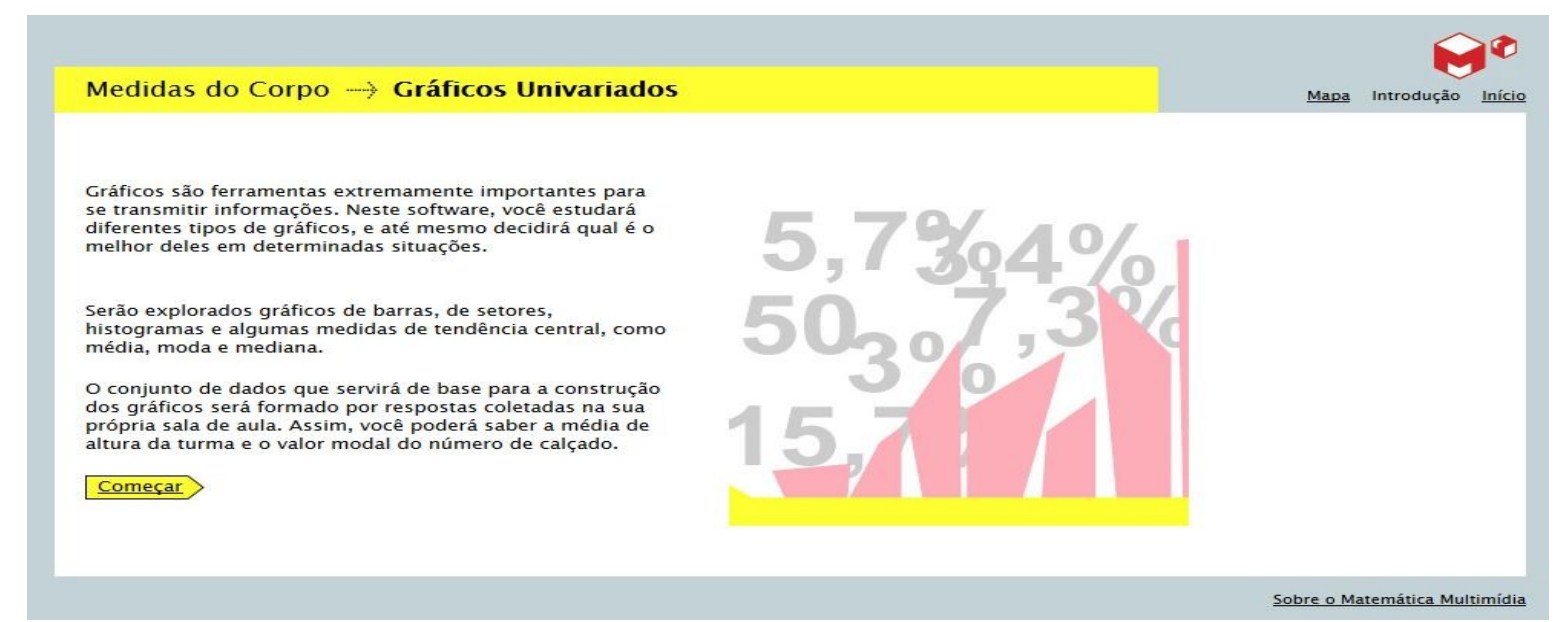

Figura 6 - Página de introdução do recurso

Além disso, está sugerido que o conjunto de dados a ser utilizado para o desenvolvimento das atividades pode ser obtido a partir de uma pesquisa estatística realizada pelos estudantes junto aos seus colegas de classe. Portanto, um dos objetivos do software é possibilitar aos estudantes o trabalho com dados que sejam coletados por eles, o que em nosso ver, poderá se caracterizar como um aspecto positivo.

Logo após clicar no ícone Começar o usuário é levado a um mapa do recurso (Figura 7). Neste mapa, o usuário terá conhecimento sobre qual será sua possível trajetória no recurso.

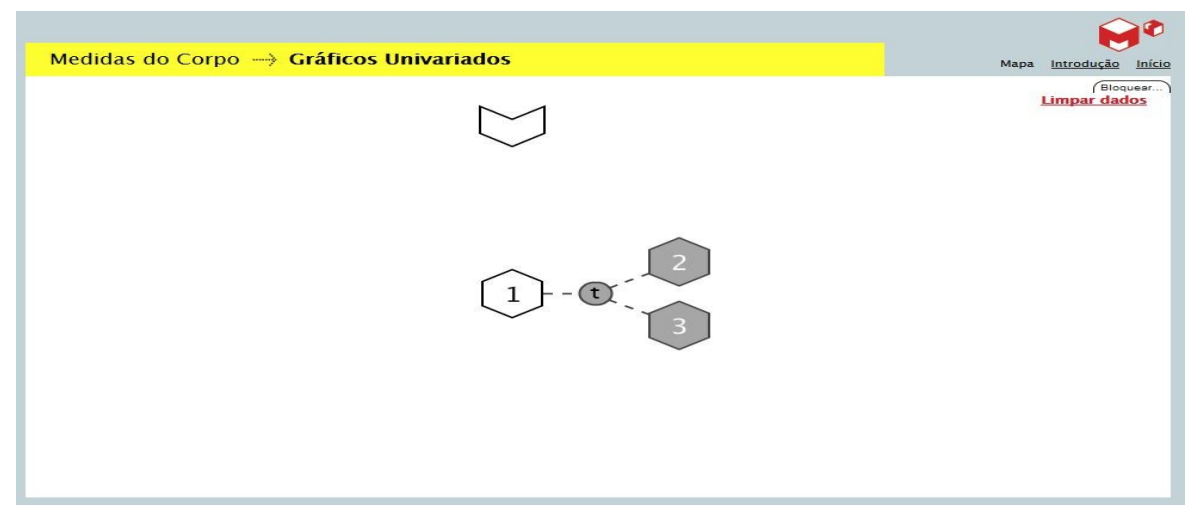

Figura 7 - Mapa do recurso

Na Atividade 1 o usuário deverá preencher uma tabela com os dados que foram previamente coletados: gênero, número do calçado e altura. Para auxiliar o usuário no preenchimento da tabela, são apresentadas instruções no lado esquerdo da página, bem como 
algumas condições sobre os dados a serem inseridos, por exemplo, o fato de que a tabela deverá conter pelo menos dez linhas válidas e, pelo menos, um indivíduo de cada gênero.

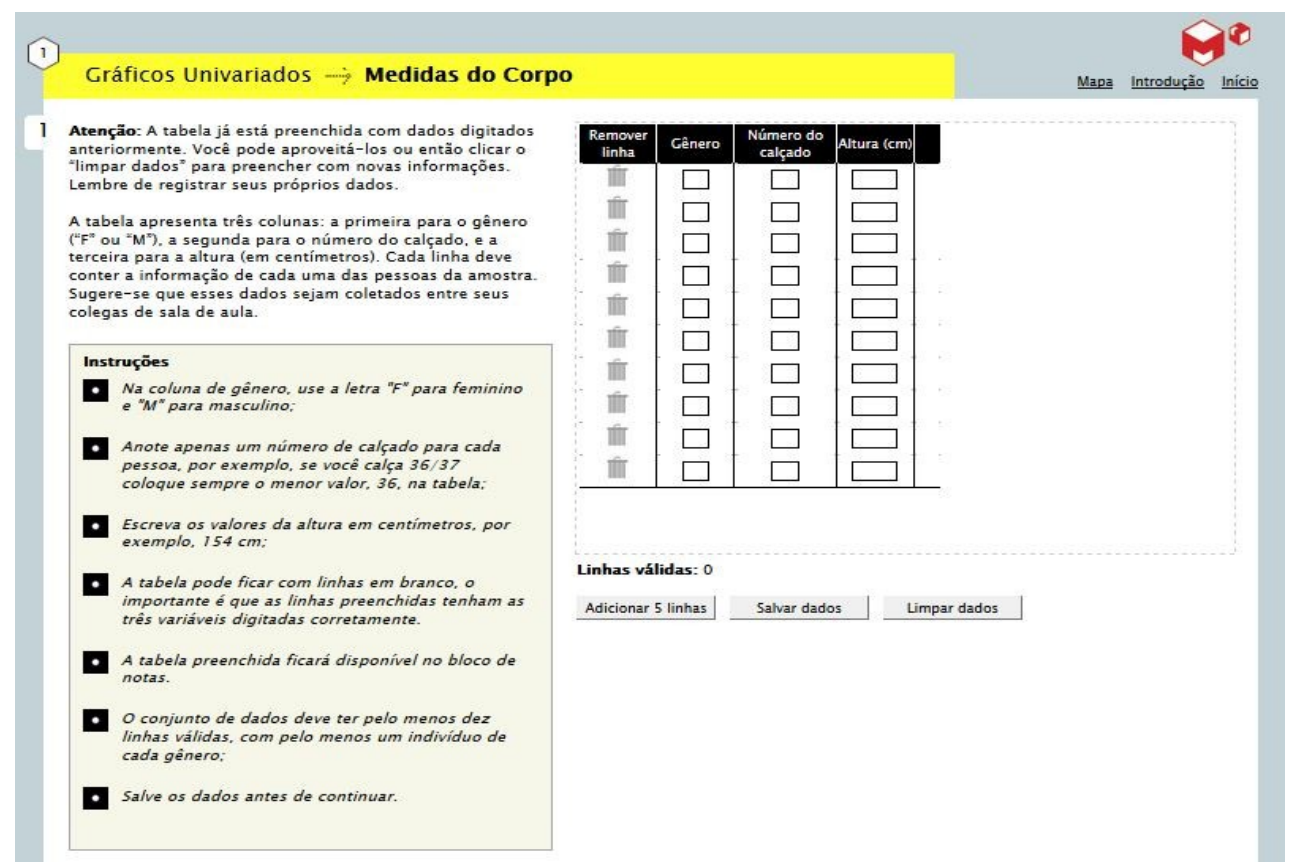

Figura 8 - Atividade 1

Ainda sobre a Atividade 1, no final da página é apresentado um breve parágrafo com o intuito de direcionar o usuário sobre o que será discutido na próxima atividade. No entanto, tal parágrafo não foi captado na Figura 8. O texto do referido parágrafo é o seguinte: “A simples observação de uma tabela de dados não nos permite analisar a existência de um padrão para as variáveis em estudo e nem a existência de associação entre elas. As medidas-resumo entregam um resumo em termos numéricos das variáveis analisadas. Vamos conhecê-las?"

Com relação ao parágrafo mencionado, entendemos que ele poderá agregar positivamente ao Potencial didático do recurso, na medida em que propõe um questionamento sobre a necessidade do aprendizado de outras representações dos dados para além da tabela de dados brutos.

Para continuarmos o nosso tour pelo software consideraremos o conjunto de dados artificiais, conforme apresentado a seguir na Figura 9. Como o nosso objetivo é o de possibilitar ao leitor uma breve imersão no recurso, optamos por trabalhar com o número mínimo de linhas válidas permitido pelo recurso: dez linhas. 


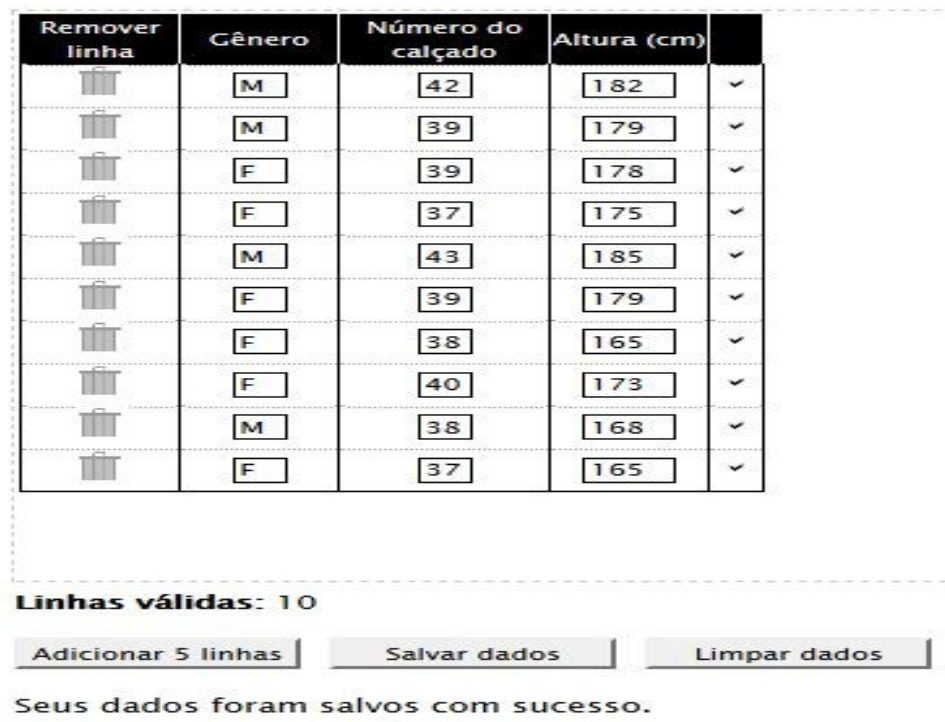

Figura 9 - Dados artificiais para as Atividades 2 e 3

Feito o preenchimento da tabela de acordo com as instruções fornecidas, bem como o armazenamento dos dados no recurso, podemos prosseguir então no desenvolvimento das atividades, seguindo para a Tela de transição, conforme apresentado na figura a seguir.

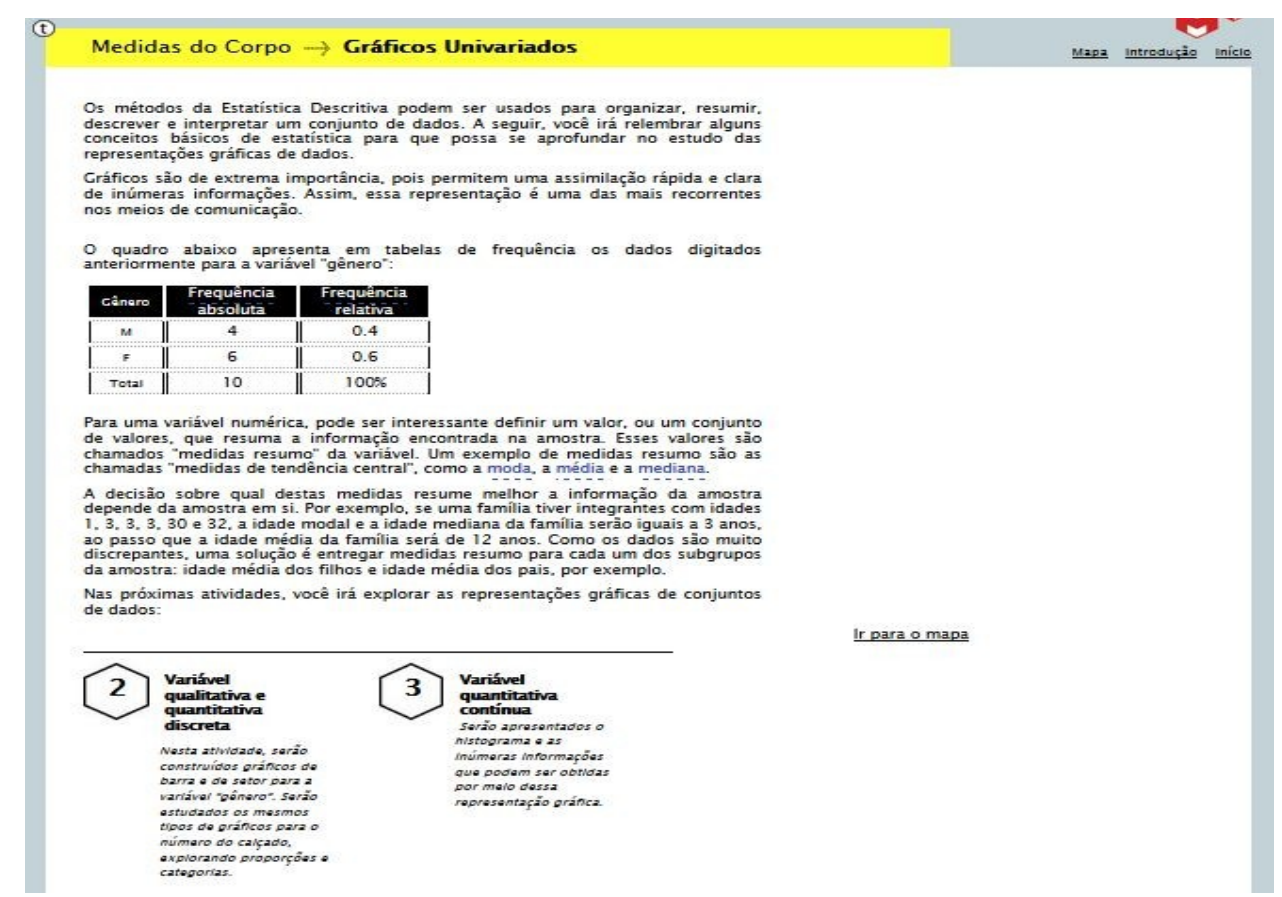

Figura 10 - Tela de transição

Nesta etapa do recurso, o usuário poderá realizar a leitura de um texto explicativo em que são apresentados de forma breve e sucinta: i) os objetivos de uma análise descritiva de dados, ii) a importância da utilização dos gráficos na representação dos dados, iii) uma tabela 
com as frequências (absoluta e relativa) da variável gênero para os dados inseridos na Atividade 1, iv) algumas medidas resumo, tais como a média, a moda e mediana e suas respectivas definições e v) a questão da representatividade de uma medida resumo em relação aos dados que ela faz referência.

Realizada a leitura do texto explicativo, o usuário poderá optar por seguir para a Atividade 2 ou Atividade 3. Na Atividade 2 o usuário realizará atividades sobre as variáveis gênero e número de calçado. Já na Atividade 3 o usuário estudará a variável altura. Vamos continuar o nosso tour seguindo para a Atividade 2.

A Atividade 2 está dividida em três partes. Na primeira parte, o usuário deverá responder uma questão com dois itens (A e B). O item A envolve a tabela de frequências da variável gênero e o seu gráfico de setores. Já o item B procura relacionar a tabela de frequências com o gráfico de barras da variável gênero. Caso o usuário forneça as respostas esperadas pelo recurso, então, ele poderá avançar para a segunda parte.

Caso contrário, ele poderá acessar algumas dicas que podem eventualmente auxiliá-lo e assim, tentar responder novamente a(s) questão(ões) incorreta(s), conforme exemplificado na Figura 11, o que consideramos algo positivo, pois o recurso não somente avalia a resposta fornecida pelo usuário mas também contribui, eventualmente, para a sua construção quando necessário.
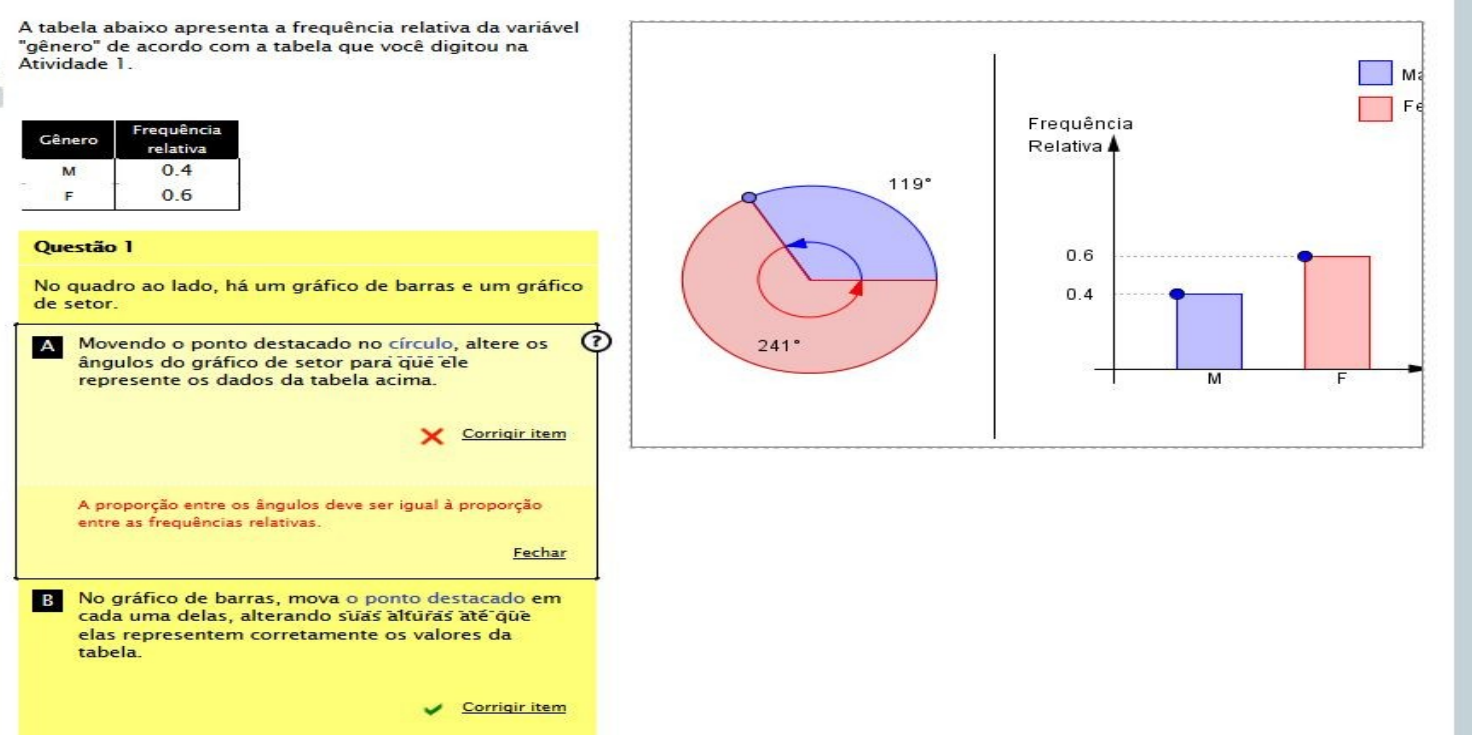

Figura 11 - Atividade 2 - Primeira parte 
Na segunda parte da Atividade 2, o usuário desenvolverá atividades que tratam do estudo da variável número do calçado tendo à sua disposição dois tipos de representação que dizem respeito a essa variável: o gráfico de barras e o gráfico de setores.

Um detalhe importante é que os dois tipos de gráficos não são apresentados simultaneamente, ou seja, estará disponível na tela somente um dos dois tipos de gráficos e, portanto, caso usuário queira ter acesso ao outro tipo de gráfico, deverá clicar no ícone Alterar gráfico.

Desse modo, para cada um dos itens a serem respondidos, o usuário poderá selecionar o gráfico que considerar mais conveniente para tal, podendo transitar de uma representação para outra sempre que necessário.

Seguindo a mesma dinâmica da Atividade 1, o usuário deverá responder três questões. A primeira questão com três itens e as outras duas, com um item cada uma. Cabe pontuar que para as duas últimas questões da segunda parte da Atividade 2 a resposta deverá ser um número maior ou igual a zero e menor ou igual a um, pois trata-se de uma proporção. A figura a seguir apresenta a segunda parte da Atividade 2.

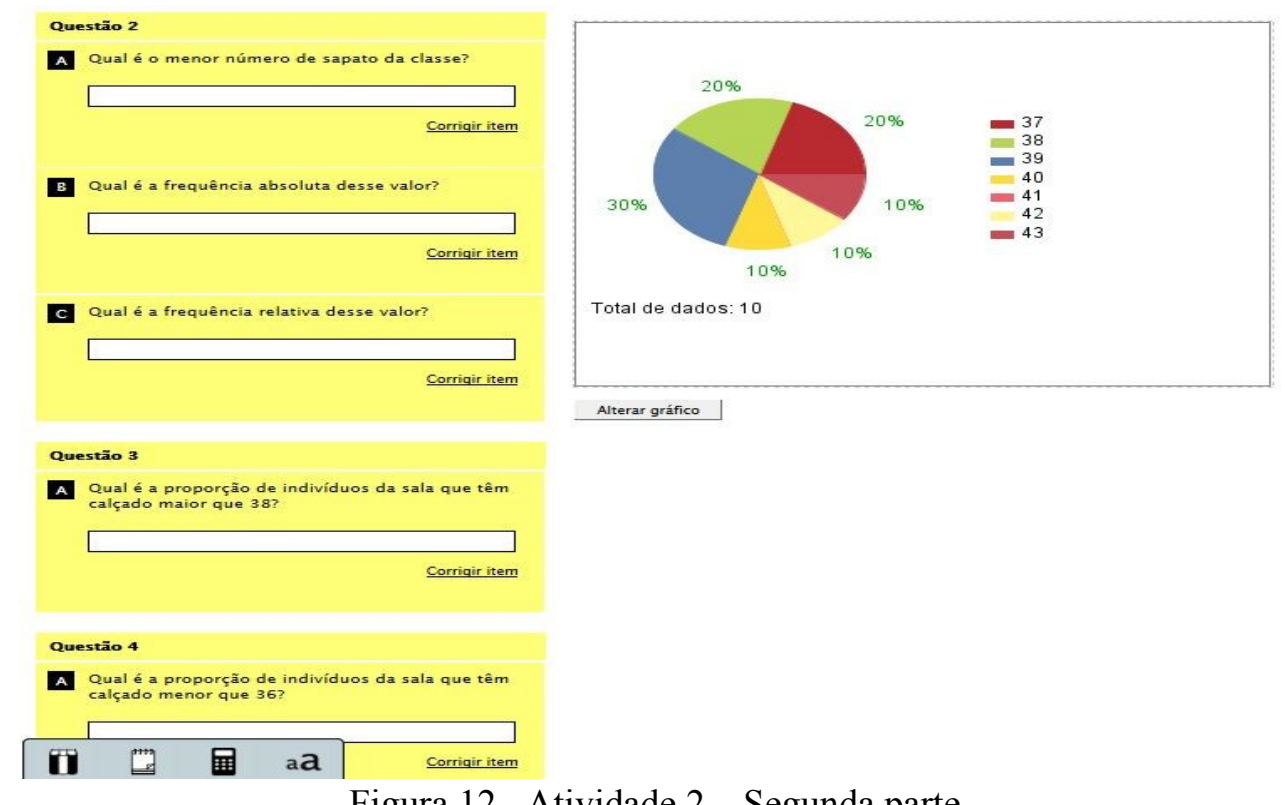

Figura 12 - Atividade 2 - Segunda parte

Além das questões que devem ser respondidas no próprio recurso, está proposta também uma outra a ser respondida no caderno: "Considerando esse conjunto de dados, responda: qual é a melhor forma de representação para responder as questões, gráfico de barras ou de setores? Por quê?" 
Dando continuidade à Atividade 2, em sua terceira parte, o usuário dará prosseguimento ao estudo da variável número do calçado. Neste momento, é apresentada uma questão que contém três itens. A ideia por trás desta questão é permitir ao usuário fazer um "corte" nos dados, através do estabelecimento de dois tipos de categorias mutuamente exclusivas, "pé pequeno" e "pé grande" 47.

Nesta categorização, o usuário acaba criando indiretamente uma outra variável, que denominaremos aqui de "tipo de pé". Esta variável é qualitativa ordinal e pode assumir dois valores: "pequeno" e "grande".

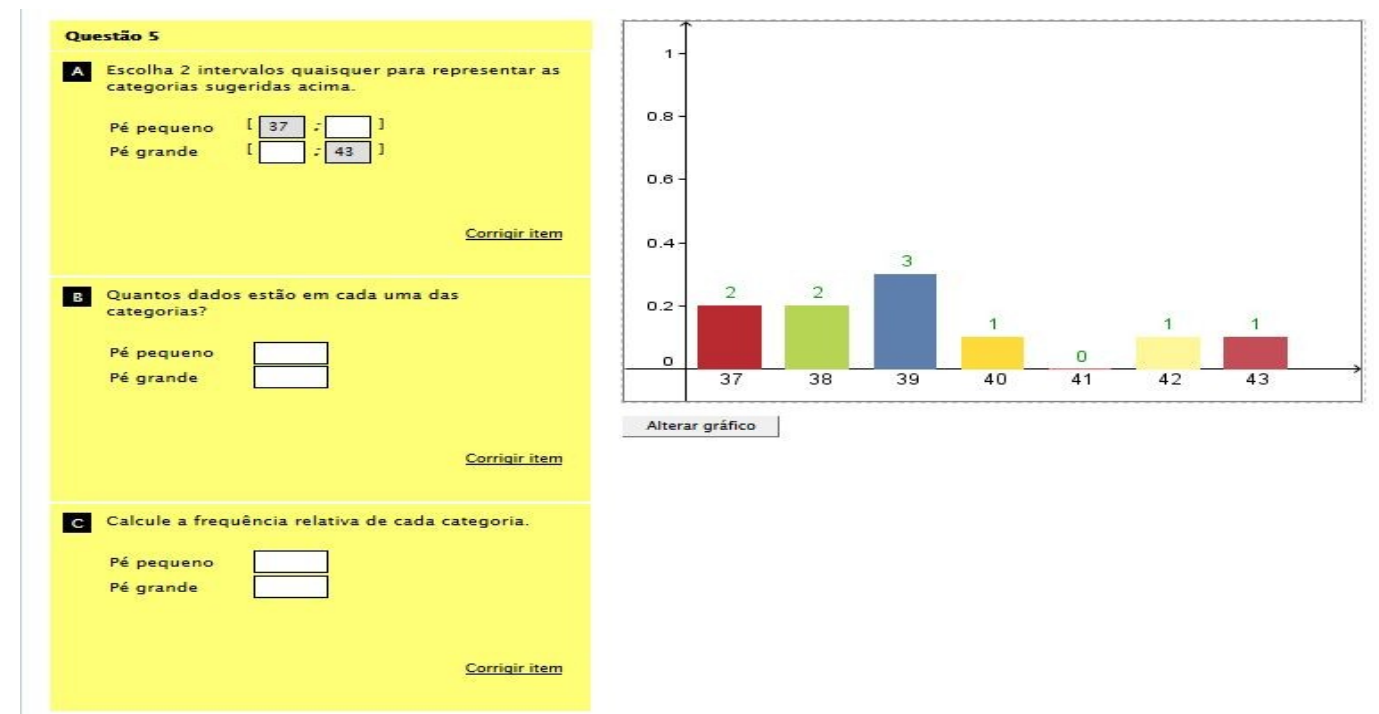

Figura 13 - Atividade 2 - Terceira parte

Após o usuário concluir a terceira parte da Atividade 2, ele será direcionado para o Mapa do recurso (Figura 7) e poderá prosseguir então para a Atividade 3, onde ele estudará a variável altura.

A Atividade 3 está dividida em quatro partes. Na primeira parte, o usuário deverá responder cinco questões com o auxílio do histograma da variável altura. A primeira questão possui dois itens e as demais, um item cada.

A sistemática das Atividades 2 e 3 é praticamente a mesma, o usuário vai avançando no recurso conforme o êxito obtido nas respostas. A figura apresentada a seguir mostra a primeira parte da Atividade 3.

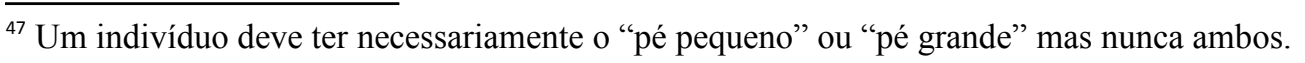



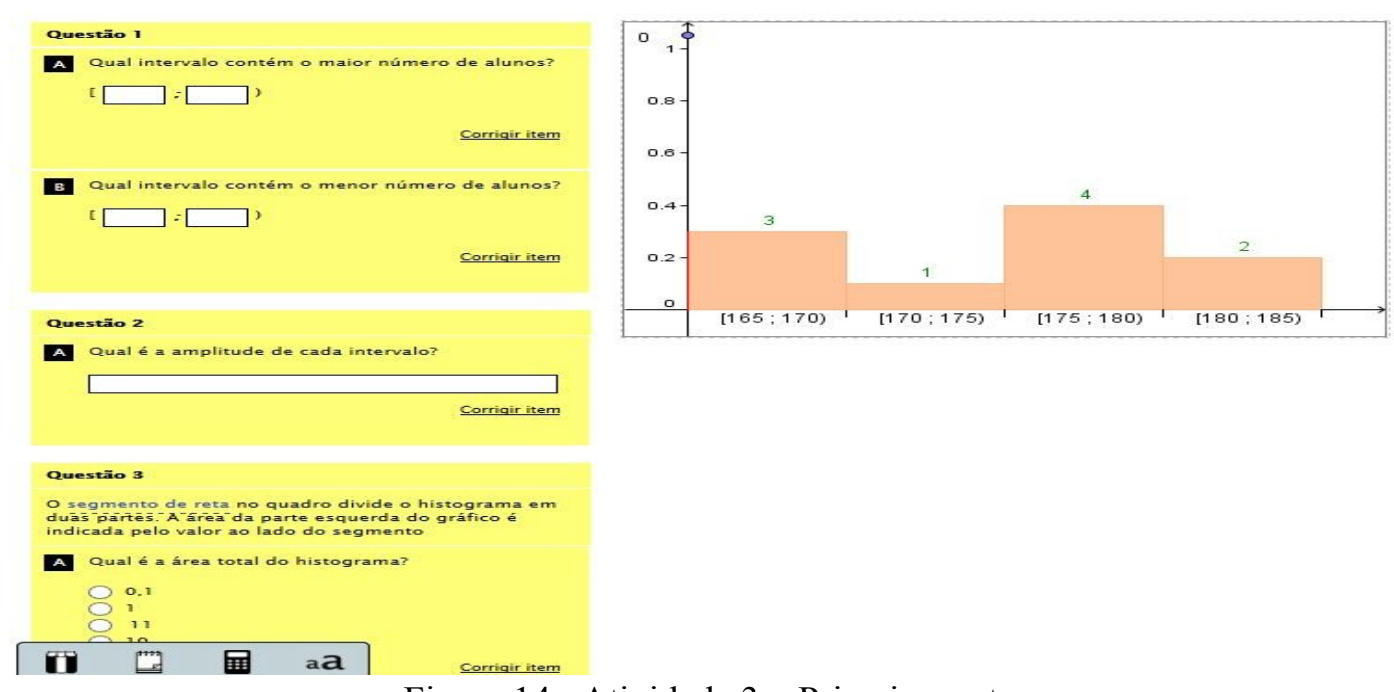

Figura 14 - Atividade 3 - Primeira parte

Na segunda parte da Atividade 3, o usuário deverá inicialmente escolher o número de intervalos de classe que será considerado para a construção do histograma, entretanto, tal como é apresentado na primeira parte, os intervalos têm todos a mesma amplitude. Esta parte contém três questões, cada qual com um item.
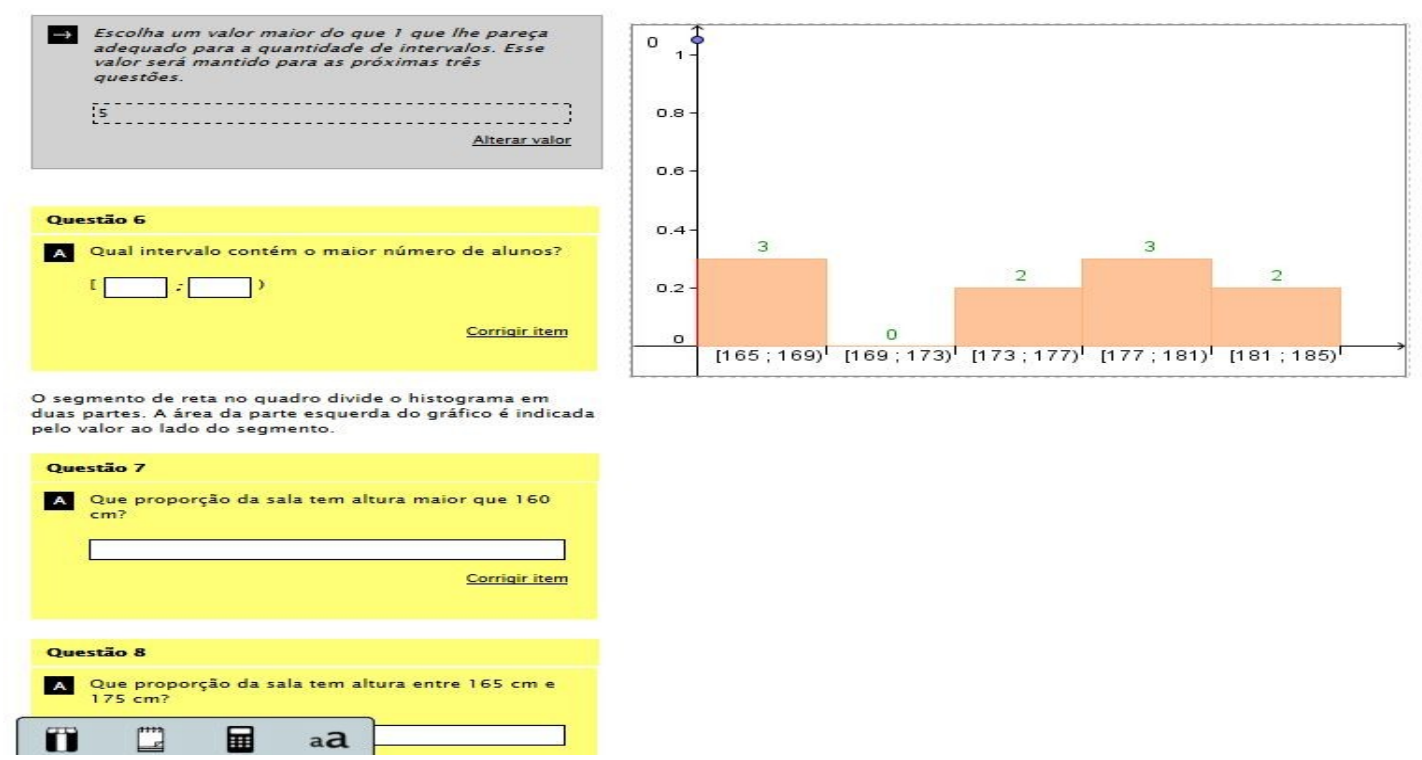

Figura 15 - Atividade 3 - Segunda parte

$\mathrm{Na}$ terceira parte da Atividade 3, o usuário deverá responder questões que tratam sobre a realização de "cortes" nos dados, por exemplo, através da mediana. No total, temos quatro questões. As três primeiras com um item cada uma e a última questão com três itens.

Para auxiliar a resolução de tais questões, encontra-se disponibilizado o histograma da segunda parte desta mesma atividade. 


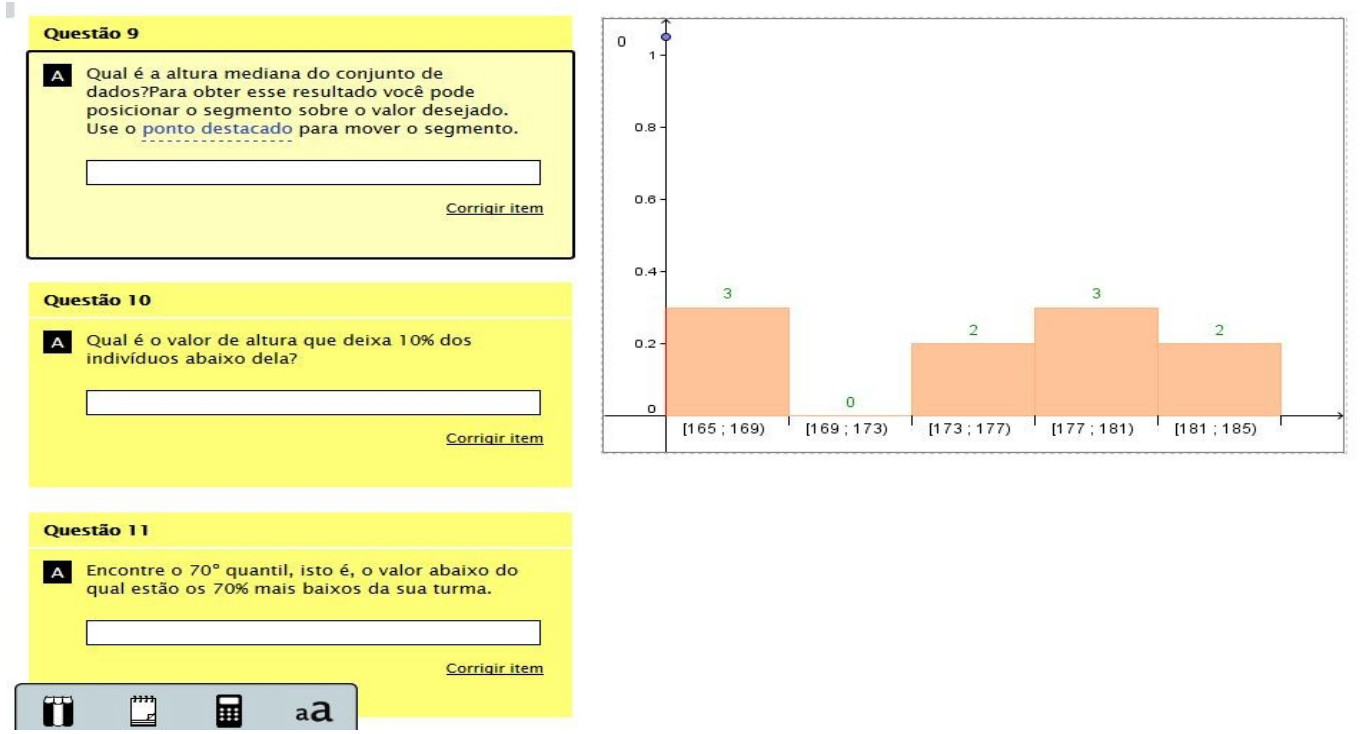

Figura 16 - Atividade 3 - Terceira parte

No fechamento da Atividade 3, portanto, em sua quarta parte, o usuário deverá responder três questões com o auxílio do mesmo histograma utilizado na segunda e terceira partes da Atividade 3.
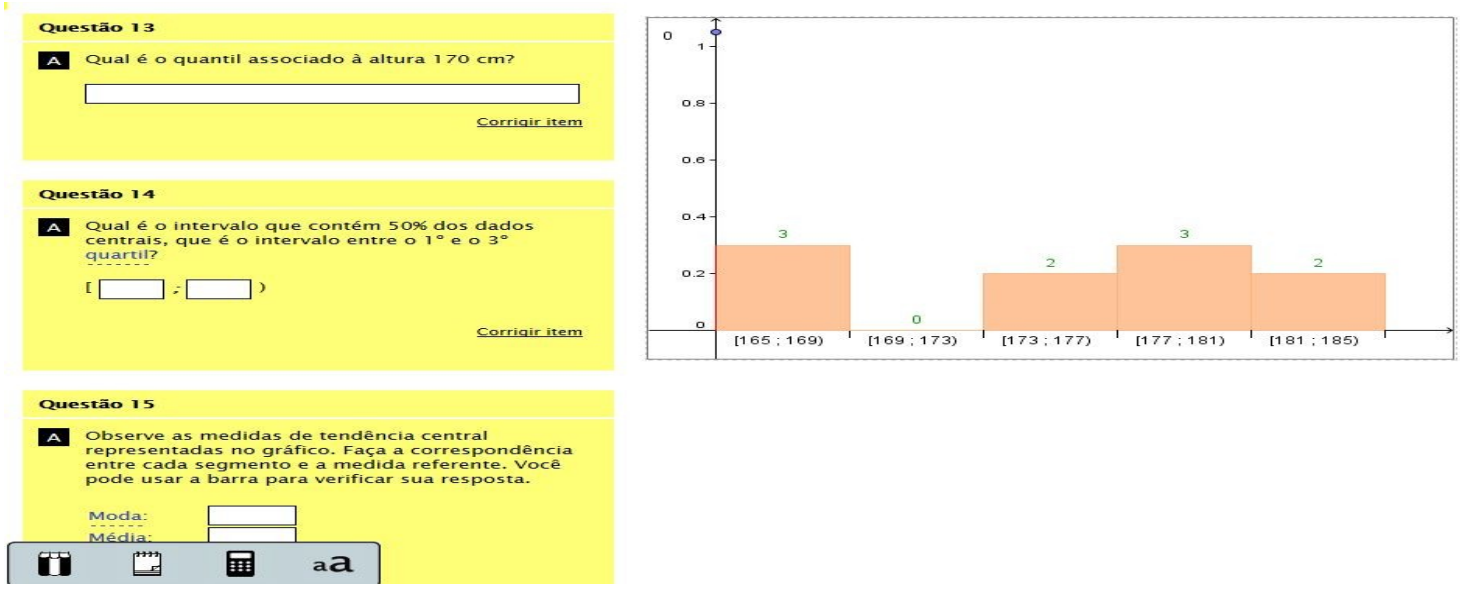

Figura 17 - Atividade 3 - Quarta parte

Cada questão possui um item. As duas primeiras questões ainda discutem a ideia de "corte" nos dados e a última questão diz respeito à moda, média e mediana da variável altura.

Concluída a Atividade 3, o usuário é direcionado novamente para o Mapa do recurso (Figura 7) e o recurso apresenta uma mensagem parabenizando-o pela conclusão das atividades.

Em caráter opcional, o usuário pode clicar no ícone no topo do Mapa do recurso (acima da imagem que traz a ordem das atividades) para ter acesso ao conteúdo da seção 
Curiosidades. Nesta seção, o usuário encontrará um texto que traz informações sobre a distribuição de renda no Brasil, bem como pretende-se relacionar o texto com o conceito de quantil $^{48}$. Antecipamos que, alguns aspectos do referido texto serão discutidos por meio do critério Contribuição à cidadania.

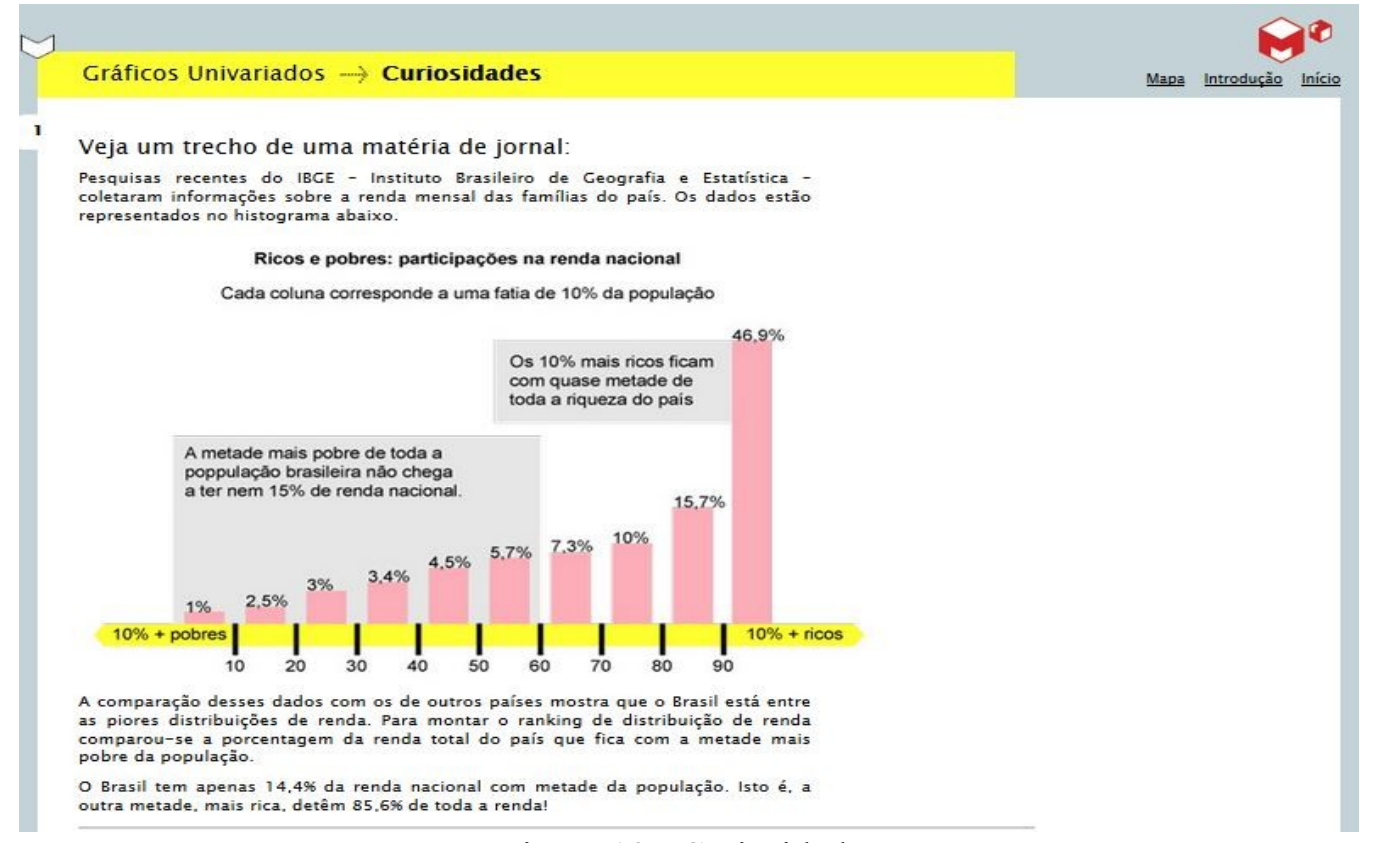

Figura 18 - Curiosidades

Feita a leitura do texto, o usuário poderá retornar ao Mapa do recurso e a utilização do recurso pode ser dada como encerrada.

Após conhecermos e explorarmos o recurso, iremos agora para a sua análise crítica.

\subsubsection{Analisando criticamente o recurso}

Nossa análise crítica será realizada seguindo a mesma ordem em que foram apresentados os critérios de análise na seção 5.2. Nesse sentido, desenvolveremos considerações sobre o recurso de acordo com os aspectos que podem ser evidenciados através de cada um dos critérios.

Em virtude da Consistência do conteúdo, em nosso ver, configurar-se inicialmente como o principal critério de análise e até mesmo ser um fator decisivo na análise crítica de um recurso quando um professor pretende eventualmente utilizá-lo em sala de aula, entendemos

\footnotetext{
${ }^{48}$ Em Magalhães e Lima $(2013$, p.27) podemos encontrar que "quantis são valores que limitam uma certa porcentagem de observações da variável [...] Por exemplo, $q_{12 \%}$ é o quantil que limita $12 \%$ dos valores inferiores do conjunto de observações ordenadas".
} 
ser pertinente destinar uma seção específica para a sua discussão, no que faremos logo após os comentários sobre o critério Estabilidade.

Além disso, nossas considerações serão desenvolvidas tomando como base a utilização online que fizemos do recurso, entre os dias 18 e 24 de janeiro de 2016. Para o desenvolvimento da nossa análise crítica utilizaremos os dados artificiais apresentados na seção 5.3.2 (Figura 9), portanto, estamos cientes das limitações acerca das conclusões que estabeleceremos a partir de tal análise.

\subsubsection{Guia didático, Usabilidade e Estabilidade (C1, C2 e C3)}

Com relação ao critério Guia didático, um primeiro ponto que gostaríamos de discutir é o "Guia do Professor" que está disponibilizado pelo recurso e que pode ser acessado através da sua página inicial (Figura 4).

O "Guia do Professor" inicialmente traz algumas informações gerais sobre o recurso, tais como: sinopse, conteúdos, objetivos, tempo estimado para o desenvolvimento das atividades, recomendação de uso e indicação de outros recursos também disponibilizados no M3 e que possuem alguma conexão com o software.

Prosseguindo na leitura do material, podemos encontrar na introdução do guia um breve texto informando sobre o que é o método científico. Em seguida, na seção "O software" encontramos uma descrição do software e as atividades que são propostas, bem como as variáveis que serão estudadas.

Seguindo adiante no Guia, podemos encontrar também informações teóricas, por exemplo, o que é frequência absoluta, o que é frequência relativa, o que são os intervalos de classe entre outras definições. Tais definições são apresentadas em língua natural, evitando-se assim a utilização de simbologia matemática, no que acreditamos que tal escolha tenha sido feita para tornar o texto acessível a um público mais amplo e não somente aos especialistas no assunto.

Enxergamos de forma positiva tal escolha do(s) autor(es) do recurso, pois não evidenciamos uma perda na precisão das definições apresentadas. Além disso, supomos que a utilização da língua natural para a representação de tais conceitos poderá eventualmente facilitar sua discussão inicial pelo professor com seus estudantes, no que acreditamos ser um caminho que favorece não apenas a compreensão dos conceitos em si, mas que pode 
contribuir também para uma efetiva apropriação da simbologia matemática que é utilizada para representá-los.

Podemos verificar também no Guia, sugestões de atividades e outros recursos do próprio M3 que podem antecipar ou ampliar a proposta do recurso em questão, o que contribui positivamente para o recurso, pois tais sugestões podem explicitar para o professor que o software está inserido dentro de uma proposta de trabalho dos conteúdos de Estatística. Consideramos isso fundamental para que a integração do recurso no planejamento da disciplina ocorra de forma mais harmoniosa, bem como para que o professor consiga identificar o momento mais conveniente para utilizá-lo junto com seus estudantes.

Já no final do "Guia do Professor" podemos encontrar duas referências que acreditamos terem sido utilizadas para a elaboração do material.

Com base nas informações apresentadas no referido material, podemos identificar que ele possui dupla finalidade: orientar e auxiliar o professor que tem a pretensão de utilizá-lo em sala de aula e contribuir para o aperfeiçoamento dos seus conhecimentos teóricos sobre os assuntos. Nossa última afirmação justifica-se, pois o material apresenta não somente reflexões teóricas sobre os conceitos estatísticos a serem trabalhados com os estudantes, mas também discute suas possíveis abordagens em sala de aula por meio do recurso em questão.

Portanto, entendemos que o Guia em questão é relevante, bem elaborado e contribui positivamente para o recurso.

Prosseguindo com a discussão sobre o critério Guia didático, verificamos em todas as atividades do recurso uma preocupação em fornecer informações claras e concisas para o professor e o usuário sobre como as atividades deveriam ser realizadas, no que entendemos que agrega positivamente para o recurso não somente com relação ao critério que estamos discutindo, mas que também no que se refere a sua Usabilidade.

Cabe pontuar também que o recurso, conforme visto na seção 5.3.2, possibilita ao usuário a realização de várias atividades, aliás, o próprio recurso pode ser considerado como uma sequência de atividades. Nesse sentido, para o usuário a tecnologia provavelmente configura-se como uma ferramenta que o possibilita responder determinadas questões, mesmo que elas não tenham sido formuladas por ele mesmo.

Um outro aspecto que consideramos importante, é o fato do recurso a todo momento fornecer para o usuário informações relevantes para o desenvolvimento adequado das atividades, além de disponibilizar ícones com informações adicionais.

Acreditamos que as questões propostas pelo recurso podem ser expandidas e eventualmente utilizadas no processo de avaliação dos estudantes. Caberá ao professor a 
elaboração de instrumentos de avaliação ou de autoavaliação a partir do recurso, assim como o planejamento do roteiro de atividades de maneira tal a garantir uma sistematização efetiva dos conteúdos, levando-se em consideração principalmente o registro das atividades pelos alunos.

Assim, de forma complementar aos questionamentos propostos pelo recurso, posteriormente a sua utilização, poderia ser proposto aos estudantes uma atividade de fichamento, a qual poderia contribuir para a sistematização dos conceitos por parte dos estudantes, pois a partir da nossa experiência como usuário do recurso supomos que dificilmente seria possível para o professor solicitar aos seus estudantes que em uma mesma aula realizassem as atividades no computador e o fichamento, principalmente em virtude do tempo de aula.

Em relação ao critério Usabilidade, levando-se em consideração o público-alvo para o qual é destinado o recurso (estudantes do Ensino Médio), podemos concluir que sua usabilidade é alta, pois para que o usuário possa desenvolver todas as atividades propostas basta que ele siga as instruções apresentadas no decorrer de cada uma das atividades.

Nesse sentido, o recurso não requisita do usuário nenhum conhecimento instrumental prévio, além disso, a sistemática das atividades é do tipo "preencha os campos abaixo", seguindo a ideia do software do tipo "exercício-e-prática", em que o usuário avança nas atividades dependendo do êxito obtido nas perguntas feitas pelo programa.

No que se refere à Estabilidade do recurso, podemos pontuar que todas as atividades anunciadas antes e durante a utilização do software foram desenvolvidas sem que observássemos erros de funcionamento. No entanto, cabe pontuar que isso nos foi possível somente após alterarmos a configuração de segurança do Java, quando incluímos o site do repositório M3 (http://m3.ime.unicamp.br/) na Lista de Exceções de Sites do Java ${ }^{49}$.

Outro ponto a ser destacado é que quando a atividade envolvia algum tipo de gráfico, surgia na tela uma "Advertência de Segurança" nos questionando se realmente gostaríamos de executar aquela aplicação ou não, no caso o gráfico a ser utilizado na atividade. Porém, logo após a confirmação de interesse na execução da aplicação, o gráfico surgia conforme anunciado.

\footnotetext{
${ }^{49}$ Inicialmente acessamos o painel de controle do Java, em seguida a guia "Segurança" e depois inserimos o endereço do repositório M3 na Lista de Exceções de Sites.
} 


\subsubsection{Consistência do conteúdo (C4)}

Discutiremos agora sobre a Consistência do conteúdo. Para o desenvolvimento de nossas considerações, procedemos de modo análogo ao que foi realizado na seção 5.3.2, ou seja, vamos percorrer cada uma das atividades e discutir a consistência do conteúdo que é apresentado. Para tal, consideraremos o conjunto de dados apresentado na seção 5.3.2 (Figura 9). Portanto, este será o nosso segundo tour pelo recurso.

Na Atividade 1 acreditamos que uma informação apresentada pelo recurso deve ser objeto de reflexão por parte do professor e de eventual discussão com os estudantes. A variável número do calçado é considerada pelo recurso como quantitativa discreta. Por outro lado, entendemos que será interessante o professor comentar com os estudantes que a variável tamanho do pé, que não é apresentada no recurso, por sua vez é quantitativa contínua. Nesse sentido, a conversa com os estudantes poderá ser encaminhada com o intuito de se evidenciar que a variável tamanho do pé ao ser discretizada pode originar uma nova variável, o número do calçado.

No que se refere às informações apresentadas na "Tela de transição", elas estão corretas e em uma linguagem adequada para o público-alvo do recurso (estudantes do Ensino Médio). Prosseguimos agora para a Atividade 2.

Na primeira parte da Atividade 2, os gráficos apresentados propositadamente de forma incorreta pelo recurso são passíveis de serem corrigidos pelo usuário, já que a ideia desta atividade é exatamente que o usuário possa confrontar tais gráficos com os dados da tabela de frequência relativa e alterá-los, de modo que eles se façam condizentes com a mesma.

Já na segunda parte da Atividade 2, o gráfico de barras apresentado está correto. Com relação ao gráfico de setores, ainda que não tenhamos acesso ao ângulo central de cada um dos setores, visualmente ele nos parece correto, comparando ainda que de forma intuitiva a área de cada um dos setores.

No que se refere às questões propostas, acreditamos que o item A da Questão 2 ("Qual é o menor número de sapato da classe?"), poderá eventualmente não ter resposta dependendo dos valores observados e, por conseguinte, os itens B e C. Note que, considerando-se o caso em que todos os números de calçados observados são iguais, por exemplo, todos os calçados possuem numeração igual a 39 , o que deveríamos considerar como sendo o menor número de calçado $?^{50}$

\footnotetext{
${ }^{50}$ Neste caso, seria pertinente discutir com os estudantes que apesar de todos os valores observados serem iguais, para o prosseguimento das atividades pode-se convencionar que o menor valor observado e o maior valor observado são ambos iguais a 39 .
} 
Desse modo, entendemos que anteriormente ao item A da Questão 2 poderia ser proposta uma outra pergunta, pois não podemos a priori estabelecer que uma amostra terá um menor e maior valor, pois os dados coletados é que irão nos informar sobre isso. A questão seria a seguinte: "Com base nos valores observados, existe um menor número de sapato da classe?".

Assim, dependendo da resposta obtida a partir desta questão pode-se então partir para a investigação de qual seria o menor número de calçado ou então seria necessário o estabelecimento de alguma convenção para o prosseguimento das atividades.

$\mathrm{Na}$ terceira parte da Atividade 2, os gráficos apresentados são os mesmos já apresentados na segunda parte. Entretanto, a questão que está colocada poderá eventualmente não ter resposta. Afirmamos isto, pois esta parte é dependente da segunda, portanto, caso todos os números de calçados observados sejam iguais, compreendemos que não há sentido a proposição de um "corte" nos dados, de modo a estabelecer as categorias "pé pequeno" e "pé grande". Seguimos agora para a Atividade 3.

Na primeira parte da Atividade 3 podemos encontrar um texto introdutório que destaca a importância do histograma para a representação gráfica de uma variável quantitativa contínua. No início do referido texto, é informado ao usuário que: "Para representar variáveis quantitativas contínuas, que é o caso da variável "altura", não se pode usar um simples gráfíco de barras $[\ldots]$ ”. Entretanto, isso não é verdade, pois o modo como a variável será estudada não depende tão somente do seu tipo, mas também do modo como o pesquisador quer tratá-la.

Por exemplo, se em uma amostra com 20 indivíduos observamos que 5 possuem $165 \mathrm{~cm}$ de altura, 5 possuem $168 \mathrm{~cm}$ de altura, 5 possuem $172 \mathrm{~cm}$ de altura e os outros 5 possuem $175 \mathrm{~cm}$. Nesse caso, é conveniente para o pesquisador tratar a variável altura como quantitativa discreta em vez de quantitativa contínua, devido ao número de valores distintos observados serem apenas quatro $(165,168,172$ e 175) e, nesse caso, o gráfico de barras poderá ser mais informativo que o histograma.

Além disso, um pouco mais adiante no texto introdutório da primeira parte da Atividade 3 está informado que no histograma a ser utilizado teremos representado nos eixos horizontal e vertical respectivamente, a altura dos alunos e a frequência relativa dos intervalos de classe, o que por sua vez não estará explicitamente indicado no gráfico, conforme veremos na Figura 19. Pontuamos, nesse sentido, que tal prática não é usual e que a informação do que será representado em cada um dos eixos é uma componente essencial do gráfico, pois nossas interpretações e conclusões terão como ponto de partida tais informações. 
Seguindo adiante, a primeira questão proposta poderá não ter resposta. Afirmamos isto, pois dependendo dos valores observados poderá ocorrer de não existir um intervalo que contenha um maior número de alunos, tampouco um intervalo que contenha um menor número de alunos. Nesse sentido, o professor poderia discutir com os estudantes que após estabelecermos a amplitude de cada um dos intervalos de classe e antes de determinarmos um intervalo que contenha o maior ou menor número de alunos, torna-se apropriado investigarmos inicialmente sobre a existência de tal intervalo.

A segunda questão trata da amplitude dos intervalos de classe e poderá ser respondida através da simples observação do histograma. Antes de analisarmos a terceira questão, comentaremos sobre o histograma que é apresentado no recurso (Figura 19).

O histograma apresentado possui um erro e que a princípio poderá passar desapercebido pelo usuário. O que ocorre é que o primeiro intervalo classe é $[165 ; 170)$. Entretanto, o retângulo cuja base deveria ser o segmento de reta com extremidades, respectivamente, nos pontos que representam os números reais 165 e 170 e, altura, igual a 0,3 unidades de comprimento tem por base o segmento de reta com extremidades nos pontos que representam, respectivamente, os números reais 0 e 170, o que está incorreto. Além disso, tal representação dos números reais no eixo das abscissas não é a usual na Matemática.

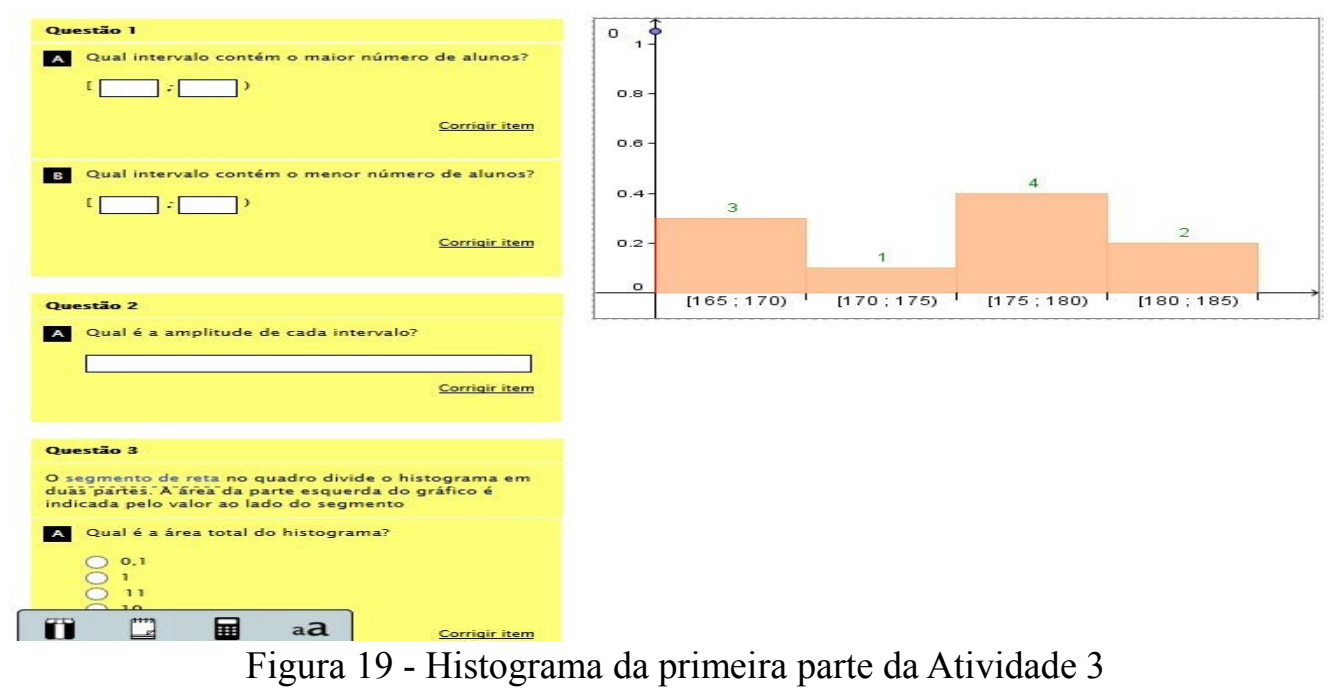

De forma mais concisa, o erro está em um dos lados do retângulo estar situado sobre o eixo vertical. Nesse sentido, será necessário que o professor discuta com os estudantes sobre tal equívoco. Aliás, ele poderá eventualmente propor aos estudantes uma questão do tipo: "Há um erro no histograma apresentado. Identifique e comente-o. Além disso, construa novamente 
o histograma". No entanto, cabe pontuar que assim como os livros didáticos, os recursos educacionais digitais não estão necessariamente isentos de erros, equívocos ou inadequações.

Retornando para a discussão sobre as questões propostas, podemos verificar na terceira questão (“Qual é a área total do histograma?”) que nenhuma das possíveis respostas disponibilizadas $(0,1 ; 1 ; 11 ; 10)$ é de fato a solução. Com efeito, pois a área do histograma (soma das áreas dos retângulos justapostos) que deveria ser apresentado corretamente na Figura 19, é igual à:

$$
5 \cdot 0,3+5 \cdot 0,1+5 \cdot 0,4+5 \cdot 0,2=5 \cdot(0,3+0,1+0,4+0,2)=5 \cdot 1=5 .
$$

Note que, o valor obtido é numericamente igual à amplitude de cada um dos intervalos de classe, isto ocorre quando os intervalos de classe possuem a mesma amplitude e o eixo vertical representa a frequência relativa.

Nesta questão, considera-se como correta a resposta que a área do histograma é igual a 1, o que não procede pois conforme verificado anteriormente a área do histograma é igual a 5. A área do histograma seria de fato igual a 1 , se no eixo vertical tivéssemos representada a densidade de frequência ${ }^{51}$ ao invés da frequência relativa ou se todos os intervalos de classe tivessem amplitude igual a 1 , no caso de mantermos o eixo vertical representando a frequência relativa.

Ponderamos também que, a frequência relativa procura captar apenas a relação entre a quantidade de dados em cada intervalo e o total de dados. Já a densidade de frequência, dá um passo adiante, captando também o modo como os dados estão distribuídos em cada intervalo e utilizando-se a densidade de frequência no eixo vertical, a área do histograma será sempre igual a 1, independentemente se os intervalos de classe possuem amplitudes iguais ou não.

Ainda na primeira parte da Atividade 3, o usuário poderá obter as respostas corretas para as duas últimas questões utilizando o histograma.

Na segunda parte da Atividade 3, os conteúdos apresentados mostram-se consistentes, exceto pelo histograma apresentado que está incorreto, conforme pode ser visto na Figura 20. As questões propostas mostram-se adequadas. Entretanto, a primeira questão ("Qual intervalo contém o menor número de alunos?") poderá eventualmente não ter resposta, caso todos os intervalos de classe tenham a mesma frequência absoluta.

\footnotetext{
${ }^{51} \mathrm{~A}$ densidade de frequência de um intervalo de classe é o quociente entre a frequência relativa do intervalo e sua amplitude.
} 


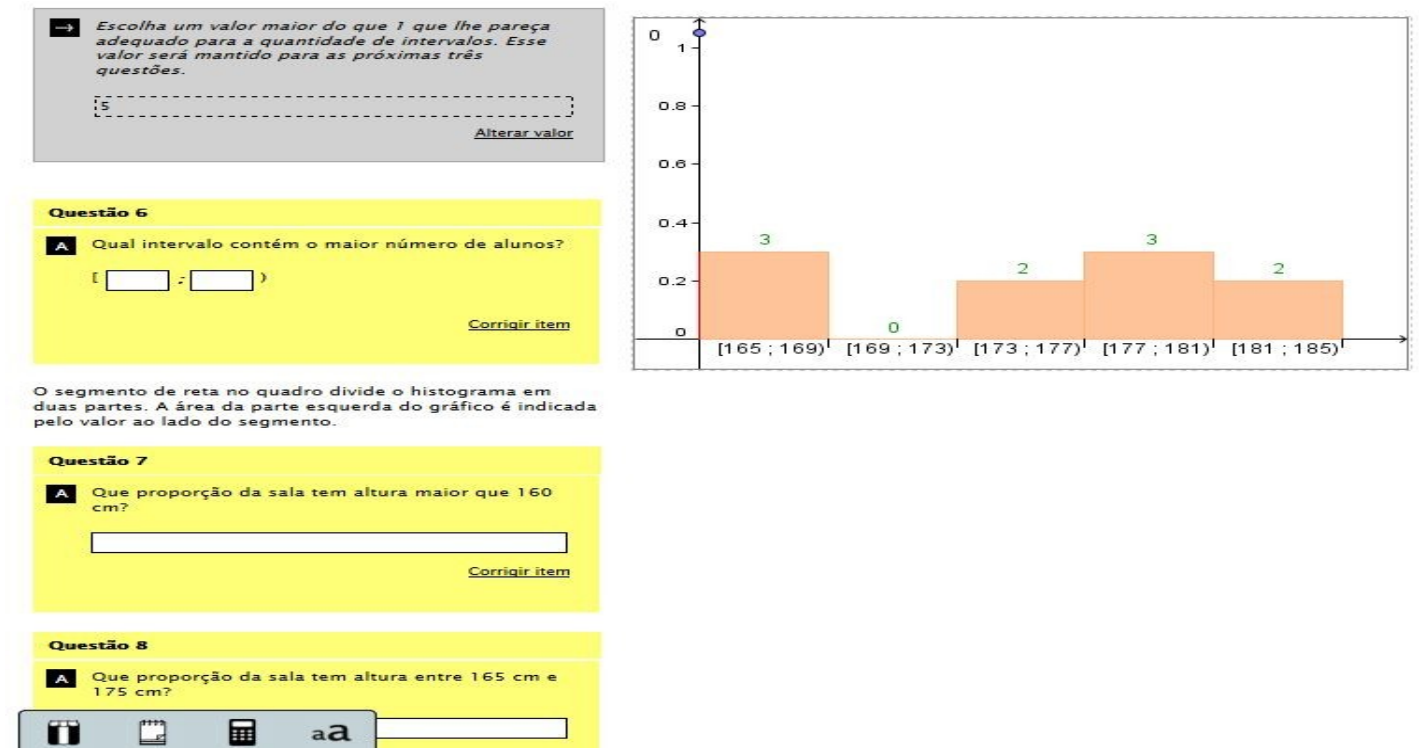

Figura 20 - Histograma da segunda parte da Atividade 3

A terceira parte da Atividade 3, começa com uma definição para mediana: " $m$ é a mediana se, pelo menos, metade dos dados for menor ou igual a $m$, e, pelo menos, metade dos dados for maior ou igual a $m$ ”. A definição apresentada está correta e em linguagem adequada para o público-alvo do recurso (estudantes do Ensino Médio). O histograma apresentado nesta parte é o mesmo que o da segunda parte da Atividade 3 (Figura 20).

A primeira questão apresentada nesta parte trata da determinação da altura mediana, por meio do histograma e também com o auxílio da ferramenta "reta deslizante". Esta ferramenta possibilita ao usuário descobrir a porcentagem da área do histograma que encontra-se à esquerda desta reta.

As outras três questões apresentadas possuem enunciados claros e permitem uma rápida interpretação pelo usuário. Apenas o enunciado da terceira questão desta parte nos parece um pouco confuso ("Encontre o $70^{\circ}$ quantil, isto é, o valor abaixo do qual estão os $70 \%$ mais baixos da turma").

$\mathrm{Na}$ quarta e última parte da Atividade 3, temos três questões que devem ser respondidas com o auxílio do mesmo histograma apresentado na segunda e terceira parte da Atividade 3.

As duas primeiras questões apresentadas estão elaboradas corretamente. A última questão desta parte, que trata da determinação da moda, média e mediana da variável altura, portanto, pressupõe a existência da moda para a referida variável. No entanto, cabe pontuar que uma distribuição de dados pode não possuir moda ou ao contrário, possuir mais do que uma. 
No caso da distribuição que estamos considerando para nossa análise crítica, temos cinco intervalos de classe com mesma amplitude e podemos verificar que ela é bimodal, ou seja, possui dois valores como moda, $167 \mathrm{~cm}$ e $179 \mathrm{~cm}$, de acordo com o histograma da Figura 20. Porém, o recurso aceita como resposta correta apenas o primeiro valor, ou seja, a moda deve ser tida como única e igual a $167 \mathrm{~cm}$, conforme pode ser visto na Figura 21, apresentada abaixo, onde optamos por colocar como moda o valor 179.

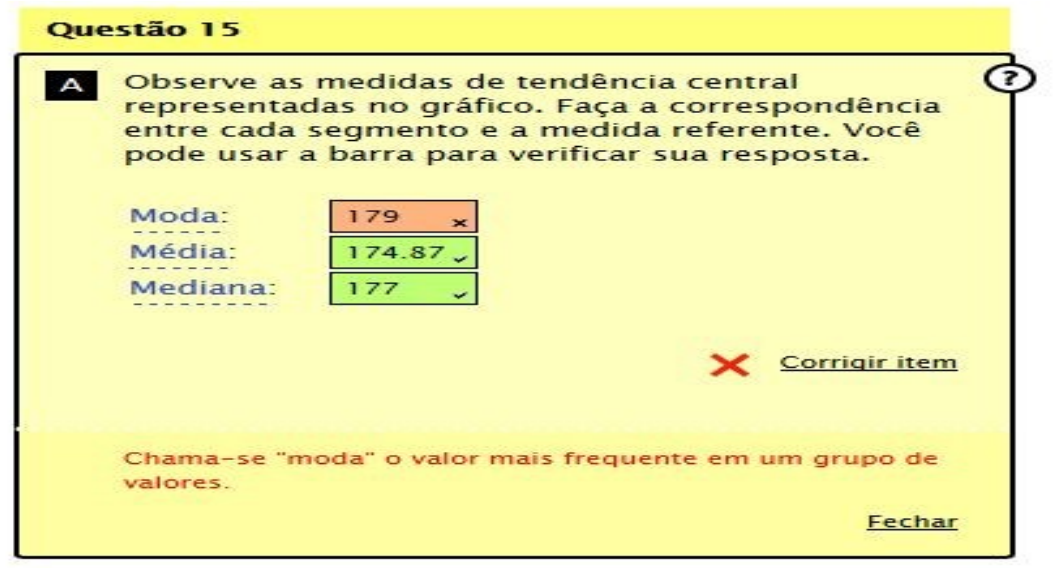

Figura 21 - Inconsistência do feedback na resposta sobre a moda

Iremos agora discutir a respeito do texto, bem como o gráfico que são apresentados na seção Curiosidades do recurso. O texto e o gráfico referidos têm por objetivo fomentar uma discussão sobre a desigualdade na distribuição de renda no Brasil, por meio do conceito de quantil. É apresentado, por exemplo, que "Os $10 \%$ mais ricos ficam com quase metade de toda a riqueza do país".

É informado ao usuário que tais conclusões resultam de uma pesquisa recente realizada pelo Instituto Brasileiro de Geografia e Estatística (IBGE) acerca da renda mensal das famílias brasileiras, a qual evidentemente varia ao longo do tempo. No entanto, não é mencionada a data em que tal pesquisa foi realizada, bem como não está disponibilizado um link de acesso à referida pesquisa.

Acreditamos que o tema proposto para discussão no texto é relevante, pois sendo ele de caráter interdisciplinar, em nosso ver, poderá possibilitar aos estudantes mobilizar seus conhecimentos sobre Estatística, Geografia e História. O que contribui para que eles possam valorizar e reconhecer a importância da aplicação dos métodos estatísticos como ferramenta de investigação em outras ciências, bem como compreender a limitação de tais métodos. 
Por exemplo, no caso do gráfico apresentado junto com o texto (Figura 18), entendemos que mesmo o estudante possuindo uma base sólida de conhecimentos estatísticos, ele só será realmente capaz de compreender o problema se puder interpretá-lo de uma forma global, relacionando-o com o contexto histórico e social do Brasil.

Cabe pontuar também que em nosso ver o gráfico apresentado poderá ser complexo para ser analisado pelo público-alvo do recurso - estudantes do Ensino Médio -, afirmamos isto pois o gráfico permeia a discussão de três aspectos: i) a renda de um indivíduo, ii) a determinação de faixas de renda não apenas com base na renda de um indivíduo, mas também no percentual de indivíduos que ela deverá conter, e que no caso é estabelecido que será de $10 \%$ e, iii) a proporção da renda nacional que está concentrada em uma determinada faixa de renda. Caberá assim ao professor vislumbrar as possíveis dificuldades dos estudantes para complementar com leituras e discussões prévias.

Após o texto e o gráfico, ainda na seção Curiosidades é apresentada uma definição para quantil. No entanto, cabe pontuar que o conceito de quantil é ensinado tradicionalmente apenas no Ensino Superior e, nesse sentido, o recurso acaba de certo modo extrapolando os conteúdos de Estatística que comumente são trabalhados no Ensino Médio. Porém, isto poderá não representar um problema se os conceitos de Probabilidade associados tenham sido abordados anteriormente.

Entendemos, no entretanto, que o professor poderá ter dificuldades em apresentar o conceito de quantil e atrelar o mesmo às atividades anteriores, criando assim eventuais obstáculos na sistematização dos conteúdos e fechamento das atividades.

Ainda sobre o critério Consistência do conteúdo, gostaríamos de pontuar sobre a ausência de histogramas com intervalos de classe com amplitudes distintas. Acreditamos que esse tipo de situação poderia desencadear uma discussão sobre a necessidade da utilização da densidade de frequência no eixo vertical, além da frequência relativa.

Como fechamento das considerações sobre o critério Consistência do conteúdo, destacamos também que o usuário dispõe de um canal de comunicação com os administradores do repositório para o envio de comentários e sugestões, conforme já observado na seção 5.3.1. Seguiremos agora para os critérios restantes. 


\subsubsection{Perspectiva epistemológica, Ferramentas de acessibilidade, Potencial} didático, Manipulação de dados e representações, Contribuição à cidadania,

Conexão com outros recursos e Licença de uso, abertura e formato técnico (C5 a C11)

Com relação à Perspectiva epistemológica, com base nas questões de investigação propostas em Reategui, Boff e Finco (2010), podemos concluir que o recurso possui um caráter comportamentalista.

Nossa afirmação justifica-se, pois o recurso: i) apresenta informações em seções breves, ii) testa o usuário em todas as atividades, iii) o usuário só pode seguir para a próxima atividade, caso todas as respostas apresentadas estejam corretas e iv) obriga o usuário, no caso de erros, a retornar ao ponto anterior. Nesse sentido, o recurso poderá em alguns momentos representar uma informatização do ensino tradicional, dado que o estudante é ensinado e avaliado pelo computador.

Um aspecto que consideramos positivo, é que o recurso se propõe a utilizar dados coletados pelos estudantes, portanto, uma tarefa que provavelmente será realizada coletivamente. No entanto, todas as atividades propostas pelo recurso a princípio, devem ser realizadas individualmente, pois não verificamos em nenhuma das atividades sugestões de resolução em grupo.

No que se refere ao critério Ferramentas de acessibilidade, pode-se verificar que o recurso possibilita ao usuário alterar o tamanho da fonte, o que poderá vir a ser utilizado principalmente por aquelas pessoas que apresentam baixa visão, no que consideramos ser algo positivo para o recurso. Por outro lado, ele não dispõe de outras ferramentas que possibilitem adaptá-lo para pessoas com outras necessidades especiais, tais como recursos de audiodescrição e possibilidade de modificação no contraste entre as cores ou modificação no próprio estilo da fonte.

A ferramenta que possibilita a alteração no tamanho da fonte possui como ícone a primeira figura da direita para a esquerda, conforme apresentado a seguir e situa-se no canto inferior esquerdo da tela do recurso.

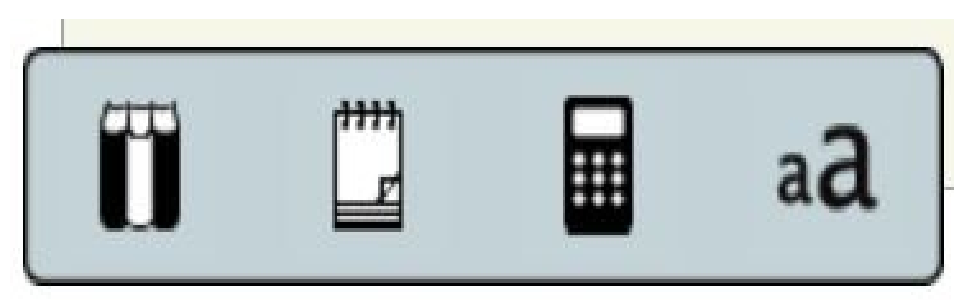

Figura 22 - Ferramentas auxiliares 
Por fim, pontuamos que o navegador de internet que utilizamos possui uma ferramenta que nos possibilitou ampliar e diminuir a tela do recurso, porém, verificamos também que tal diminuição ou ampliação da tela poderá acarretar distorções nos gráficos ou até mesmo tornálos de difícil visualização, o que limita, portanto, o potencial de tal ferramenta.

No próximo critério, discutiremos sobre o Potencial didático do recurso, embora já tenhamos refletido um pouco sobre tal aspecto quando discutimos sobre a Consistência do conteúdo.

Uma primeira consideração que gostaríamos de realizar é a de que consideramos como positivo o fato do recurso permitir ao usuário explorar três tipos de variáveis: qualitativa nominal (gênero), quantitativa discreta (número do calçado) e quantitativa contínua (altura).

Isso poderá possibilitar ao usuário comparar as variáveis e suas possíveis representações, bem como discutir a adequação das mesmas. Por exemplo, para uma variável quantitativa discreta, qual dos seguintes gráficos será mais informativo: o gráfico de barras ou o gráfico de setores? Isso depende tão somente do tipo da variável ou torna-se pertinente também verificar a quantidade de valores distintos observados na amostra?

Outro ponto que entendemos ser pertinente destacar é que, em nosso ver, as questões propostas pelo recurso contribuem para que o usuário possa realmente desenvolver uma compreensão sobre os conceitos abordados e não apenas memorizá-los.

Podemos até pontuar que o recurso permite ao usuário deslocar o foco dos cálculos e fórmulas, para a compreensão dos conceitos. Aliás, o recurso disponibiliza um bloco de notas e calculadora para o usuário (segundo e terceiro ícones da esquerda para a direita, conforme a Figura 22). Acreditamos também que o recurso possibilita ao usuário realizar ações que dificilmente seriam reproduzidas nos ambientes de aprendizagem tidos como tradicionais, suportados apenas por lápis e papel.

Por exemplo, as atividades onde o usuário pode controlar a "reta deslizante" e verificar a porcentagem da área do histograma que fica a esquerda da reta ou no caso da segunda parte da Atividade 3, bem como na atividade onde ele pode escolher a quantidade de intervalos de classes que será considerada para a construção do histograma e logo em seguida, o recurso apresenta o histograma desejado.

Por meio destes elementos, o usuário acaba explorando um ambiente de "Estatística dinâmica", manipulando ferramentas e parâmetros, verificando assim como que em tempo real o resultado de suas ações sobre os gráficos ou medidas resumo.

Para fecharmos este critério, entendemos que as atividades propostas estão bem alinhadas com o objetivo do recurso e de fato possibilitam que ele cumpra com seus 
propósitos. Prosseguiremos agora para o próximo critério: Manipulação de dados e representações.

Já vimos que o recurso requisita do usuário a inclusão de no mínimo 10 linhas válidas. Com o intuito de descobrir o número máximo de linhas válidas que o usuário pode inserir no recurso, nos dirigimos para a tela da Atividade 1 (Figura 8) e ficamos clicando no ícone Adicionar 5 linhas e considerando possíveis erros na contabilização dos clicks e que os dados de todas essas linhas inclusas sejam de fato armazenados no recurso, pudemos verificar que é possível trabalhar com no máximo 200 linhas, no que consideramos ser algo positivo.

Essa ampla possibilidade de variação na quantidade de dados poderá permitir que o usuário trabalhe com amostras de tamanhos variados, o que poderá ser útil no estudo da influência do tamanho da amostra sobre os gráficos e medidas de posição.

O professor poderia propor que seus estudantes investiguem o comportamento das variáveis para cada amostra e, posteriormente para a população, bem como, que eles comparem os resultados observados. Desse modo, acreditamos que a ideia de variabilidade poderia ser explorada com os estudantes ainda que de forma implícita, o que poderia vir a suscitar o estudo das medidas de dispersão.

Com respeito aos tipos de representações que o usuário tem a oportunidade de lidar, podem ser identificadas as seguintes: i) tabela de dados brutos, ii) tabela de frequências (absoluta e relativa), gráfico de setores e gráfico de barras para variáveis qualitativas, iii) gráfico de barras e gráfico de setores para variáveis quantitativas discretas e iv) histograma para variáveis quantitativas contínuas.

Entendemos essa variedade de representações como algo positivo, principalmente pelo fato de possibilitar que o usuário venha a transitar de uma representação para outra e até mesmo ter acesso a mais do que uma representação simultaneamente, conforme pode ser visto na primeira parte da Atividade 2.

Em relação ao critério Contribuição à cidadania, em um primeiro momento, consideramos que o recurso não contém de forma explícita, aspectos e informações que podem desencadear qualquer tipo de discriminação entre os estudantes.

No entanto, entendemos que é fundamental que o professor anteriormente a uma proposta de pesquisa em que é necessária a coleta e análise de dados pelos estudantes, venha a refletir sobre as variáveis que serão por eles investigadas, já que elas podem ser apropriadas ou não para discussão em sala de aula. Um ponto que, em nosso ver, poderá desencadear eventuais discussões entre os estudantes, diz respeito à categorização que deve ser realizada 
na terceira parte da Atividade 3, onde eles devem definir intervalos para as categorias "pé pequeno" e "pé grande".

Provavelmente, será necessário que o professor comente com os estudantes que a determinação de tais categorias possui caráter subjetivo. Portanto, os intervalos associados a cada categoria não devem ser concebidos como regra, mas sim como uma escolha dentre as existentes.

A última consideração que gostaríamos de realizar sobre este critério, trata do texto da seção Curiosidades e que aborda a distribuição de renda no Brasil. Conforme já pontuado no critério Consistência do conteúdo, entendemos que o tema proposto é relevante e pertinente para o professor abordar com seus estudantes.

Com respeito ao critério Conexão com outros recursos, podemos verificar no "Guia do Professor" que o recurso oferece indicações de outros materiais que podem antecipar, ampliar ou dar prosseguimento em sua proposta de trabalho, inclusive sugerindo uma possível ordem na utilização dos recursos que lá estão indicados, o que consideramos algo positivo e que poderá contribuir com o trabalho do professor na integração do recurso no planejamento da disciplina.

Dentre os recursos que estão indicados no "Guia do Professor", cinco deles estão disponibilizados no repositório M3, aliás, dois deles utilizam o mesmo conjunto de dados do "Medidas do corpo: gráficos univariados" " Há ainda um outro recurso que está mencionado neste mesmo material, no entanto, não o localizamos no repositório ${ }^{53}$.

Podemos pontuar também sobre outro recurso que está indicado e que encontra-se alocado no repositório CDME, trata-se do software "Distribuição de frequências e seus gráficos".

\footnotetext{
${ }^{52}$ Os recursos mencionados são os seguintes: 1. Variáveis antropométricas, 2. Gráficos estatísticos: barras e setores, 3. Gráficos estatísticos: histograma, 4. Medidas do corpo: boxplot e 5. Medidas do corpo: gráfico de dispersão. Os recursos 4 e 5 são àqueles que utilizam o mesmo conjunto de dados que o "Medidas do corpo: gráficos univariados".

${ }^{53}$ É um vídeo cujo nome é "Expresso lanches".
} 


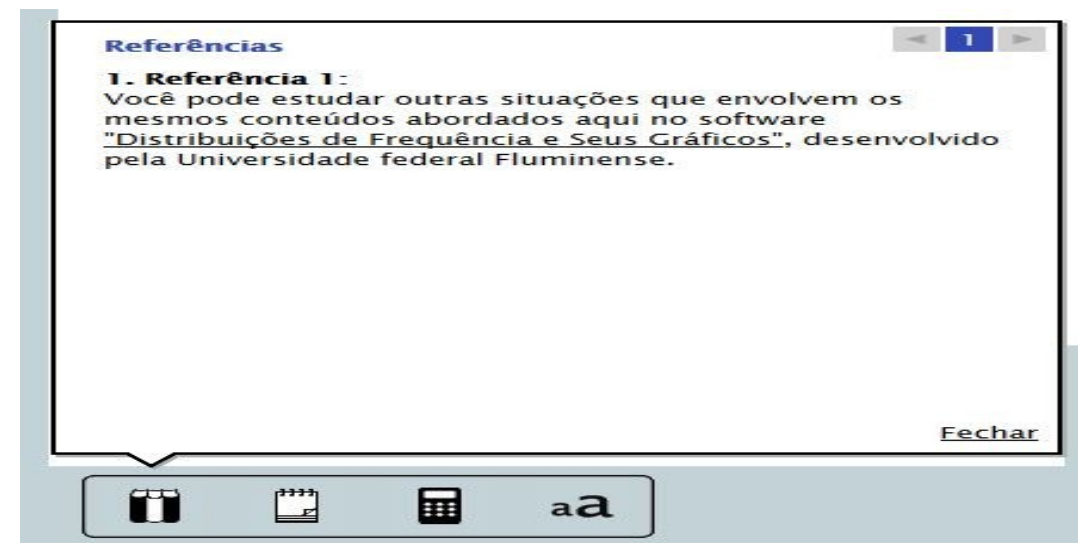

Figura 23 - Indicação de um recurso do CDME

Finalizando este critério, enxergamos de forma positiva o fato de que os recursos indicados sejam REA, o que contribui para a divulgação das obras e o que acreditamos que aumenta potencialmente a chance de remixagem dos recursos ${ }^{54}$. Para o encerramento da nossa análise crítica, discutiremos acerca da Licença de uso, abertura e formato técnico da obra.

Conforme dito na seção 5.1.1, a licença de uso do recurso é a mesma de todos os outros recursos do repositório M3, portanto, o usuário tem permissão para copiar, distribuir, exibir e executar a obra, bem como criar obras derivadas. Entretanto, não é permitido o uso comercial das obras, tampouco o seu relicenciamento sobre uma licença mais restritiva e, portanto, ele é um REA.

Consideramos isso coerente e necessário, sobretudo pelo fato que a elaboração dos recursos do repositório M3 ter contado com o financiamento público, mais especificamente do governo federal. Nesse sentido, entendemos que tais materiais devem necessariamente ser concebidos como um bem comum, disponíveis e potencialmente acessíveis a todos àqueles que queiram utilizá-los.

No que se refere ao formato técnico, verificamos que todas as páginas da web em que estão disponibilizadas as atividades do recurso estão construídas em $\mathrm{HTML}^{55}$, que por sua vez é um formato aberto. Os gráficos apresentados no decorrer das atividades foram construídos a partir do Geogebra, um software cuja licença de uso garante a sua gratuidade para o usuário, bem como é permitido copiá-lo, modificá-lo e distribuí-lo, desde que seja para uso não comercial.

\footnotetext{
${ }^{54}$ No contexto dos REA, a remixagem é tida como a criação de obras derivadas a partir da combinação, seja na íntegra ou não, de dois ou mais REA já existentes.

${ }^{55} \mathrm{Na}$ Wikipedia, podemos encontrar que HTML "é uma linguagem de marcação utilizada na construção de páginas da Web. Documentos HTML podem ser interpretados por navegadores". Disponível em: $<$ https://pt.wikipedia.org/wiki/HTML>. Acesso em: 22 de jan. 2016.
} 
Por outro lado, conforme pontuado na seção 5.3.1, dentre os requisitos técnicos para que o recurso possa ser utilizado é que o Java 1.6+ e o Adobe Flash Player 9.0+ devem estar instalados no computador. O Java é disponibilizado gratuitamente para download e instalação, bem como o Adobe Flash Player.

No entanto, arquivos em Flash podem ser executados, mas não editados, o que inviabiliza o remix da obra, devido a não disponibilização do código-fonte para a edição do recurso. Nesse sentido, verifica-se que em teoria o remix da obra é permitido de acordo com a sua licença de uso, porém, na prática, ele poderá ser inviabilizado devido ao fato do recurso não disponibilizar o seu código-fonte.

Finalizada nossa análise crítica, iremos agora relatar e analisar os resultados de uma experiência na utilização e avaliação do recurso "Medidas do corpo: gráficos univariados" em uma oficina para professores de Matemática. 


\section{Uma experiência na utilização e avaliação do recurso "Medidas do corpo: gráficos univariados" em uma oficina para professores de Matemática}

\subsection{Proposta e desenvolvimento da oficina}

No dia 24 de outubro de 2015, foi ministrada junto com a Profa. Viviana Giampaoli ${ }^{56}$ uma oficina promovida pelo Centro de Aperfeiçoamento do Ensino de Matemática "João Affonso Pascarelli" (CAEM) do Instituto de Matemática e Estatística da Universidade de São Paulo (IME-USP) intitulada "Podemos ensinar Estatística com objetos digitais?" com uma duração de 3 horas. ${ }^{57}$

A oficina tinha como público-alvo professores de Matemática da Educação Básica. No entanto, por meio de uma breve conversa com os 10 participantes da oficina, pudemos apurar que alguns deles eram: estudantes da licenciatura em Matemática do IME-USP, uma coordenadora pedagógica, uma professora do Ensino Fundamental I, professores de Matemática do Ensino Fundamental II e Médio.

Os objetivos que estabelecemos para a oficina foram os seguintes: discutir sobre a utilização de objetos digitais no contexto do ensino da Estatística no Ensino Médio, divulgar repositórios que disponibilizam objetos digitais para o ensino de Probabilidade e Estatística e, possibilitar aos participantes uma breve experiência na utilização e avaliação do recurso "Medidas do corpo: gráficos univariados".

A oficina foi dividida em três momentos.

Em um primeiro momento, discutimos com os participantes sobre fundamentos para a utilização das Tecnologias da Informação e Comunicação (TIC) na Educação Básica, bem como apresentamos elementos da legislação educacional que tratam do tema.

No segundo momento, procuramos revisar e discutir com os participantes da oficina alguns dos conceitos de Estatística que tradicionalmente são abordados no Ensino Médio, tais como: população, amostra, variável, tipos de variáveis e gráficos estatísticos.

No terceiro e último momento da oficina, utilizamos junto com os participantes o recurso "Medidas do corpo: gráficos univariados", bem como discutimos cada uma das

\footnotetext{
${ }^{56}$ Profa. do Depto. de Estatística do IME-USP e orientadora desta pesquisa.

${ }^{57}$ Nesta oficina, a definição de objeto digital considerada é a mesma que aquela apresentada na seção 1.3.
} 
atividades propostas pelo recurso, com o intuito de elucidar algumas das vantagens e desvantagens da sua utilização em sala de aula. Após concluirmos a utilização do recurso, solicitamos dos participantes uma avaliação do recurso ${ }^{58}$.

\subsection{O questionário de avaliação e os resultados da avaliação dos participantes}

O questionário de avaliação do recurso (Anexo I), elaborado junto com a Prof. Viviana Giampaoli teve como base as questões apresentadas em Reategui, Boff e Finco (2010), continha afirmações nas quais o participante deveria assinalar o seu grau de concordância em relação a cada afirmação ou até mesmo se ele não sabia avaliar qual era o seu grau de concordância com a afirmação. No final do questionário o participante dispunha também de um espaço para a realização de algum comentário sobre o recurso ou os itens de avaliação apresentados.

Por exemplo, uma das afirmações trazidas era que: As orientações e instruções oferecidas são claras, objetivas e suficientes. Deste modo, cada participante deveria escolher uma dentre as seis possíveis respostas: "Discordo Plenamente", "Discordo Parcialmente", "Nem discordo Nem concordo", "Concordo Parcialmente", "Concordo Plenamente" e "Não sei avaliar".

Cabe pontuar que além de afirmações específicas, ou seja, que diziam respeito exclusivamente ao recurso utilizado, o questionário continha também perguntas sobre a infraestrutura das TIC existente na escola em que o participante possuía a maior carga didática, bem como existiam outras afirmações de caráter geral, acerca da utilização de recursos educacionais abertos digitais (REA digitais).

A seguir, apresentaremos alguns dos resultados da avaliação dos participantes, resultados estes os quais consideramos pertinentes, tendo em vista o objetivo estabelecido neste trabalho ${ }^{59}$. No entanto, todos os resultados da avaliação dos participantes podem ser conferidos no Apêndice B. Os questionários respondidos e o modelo do Termo de

\footnotetext{
${ }^{58} \mathrm{O}$ questionário de avaliação aplicado junto aos participantes da oficina não foi submetido a um pré-teste.

${ }^{59} \mathrm{~A}$ análise dos questionários dos participantes foi realizada em um momento posterior à análise crítica que realizamos do recurso. Fizemos isso com o intuito de que tais resultados não viessem a influenciar nossa análise crítica.
} 
Consentimento Livre e Esclarecido que foi assinado por cada um dos participantes da oficina encontram-se disponibilizados no Anexo II. ${ }^{60}$

Procuramos selecionar para discussão dos resultados, um item de cada um dos seguintes blocos: "Conteúdo", "Linguagem e Orientações”, "Interação" e "Navegação". Além disso, selecionamos para discussão dos resultados também, um item que trata de aspectos gerais acerca da utilização de um recurso educacional aberto digital.

A escolha dos itens para discussão foi realizada de modo que pudéssemos estabelecer um paralelo entre o próprio item e algum dos critérios de análise que apresentamos na seção 5.2. Portanto, o item a ser discutido nos remete necessariamente a algum dos critérios de análise. Além disso, pontuamos que o conjunto de dados utilizado pelos participantes na oficina foi o mesmo que utilizamos para o desenvolvimento da análise crítica do recurso.

Iniciamos com a apresentação dos resultados do item $g$ do bloco "Conteúdo" e que está relacionado com o critério Consistência do conteúdo que consideramos para a nossa análise crítica. A afirmação é a seguinte: O recurso está livre de erros.

Os resultados foram os seguintes: 2 participantes discordaram plenamente da afirmação, 2 participantes discordaram parcialmente da afirmação, 2 nem discordaram nem concordaram com a afirmação, 1 participante concordou parcialmente com a afirmação e os outros 3 demais participantes concordaram plenamente com a afirmação.

De acordo com a nossa análise crítica, o recurso não está isento de erros, mais especificamente em algumas das respostas que ele fornece para o usuário, conforme pode ser visto na seção 5.3.3.2, onde discutimos o histograma que é construído pelo recurso, bem como a inconsistência no feedback sobre a moda.

Nesse sentido, seria razoável esperarmos que todos os participantes discordassem plenamente da afirmação, no entanto, observamos que apenas 2 deles assim o fizeram. Além disso, conforme visto em nossa análise crítica, alguns dos erros apresentados pelo recurso não nos parecem ser de fácil e rápida identificação, o que reforça, portanto, o papel fundamental do professor como investigador de tais equívocos, a fim de evitar o desenvolvimento de conceitos incorretos pelos estudantes.

O próximo item a ser comentado é o item $b$ do bloco "Linguagem e Orientações". Este item possui relação com o critério Guia didático de nossa análise e a afirmação apresentada é a seguinte: As orientações e instruções oferecidas são claras, objetivas e suficientes. Os

\footnotetext{
${ }^{60} \mathrm{O}$ título da dissertação que está apresentada no modelo é ligeiramente distinto daquele que adotamos para versão final do texto. Isso se fez necessário pois o nosso projeto de pesquisa sofreu algumas alterações que implicaram em tal mudança.
} 
resultados foram os seguintes: 6 participantes concordaram parcialmente com a afirmação e os 4 demais participantes concordaram plenamente com a afirmação.

Assim, embora o recurso tenha sido utilizado pelos participantes após explicações e sob supervisão, 6 deles concordam parcialmente em relação à clareza e objetividade das instruções, sinalizando que as mesmas podem ser aprimoradas ou que é necessário um tempo maior de familiarização com o recurso.

Agora, comentaremos os resultados do item $b$ do bloco "Interação". A afirmação apresentada neste item é: Permite avançar nas etapas ou níveis somente se o aluno dá a resposta esperada. Note que este item está alinhado com o critério Perspectiva epistemológica que adotamos em nossa análise e os resultados verificados foram os seguintes: 1 participante discordou parcialmente da afirmação, 1 nem discordou nem concordou com a afirmação e os outros 8 participantes concordaram plenamente com a afirmação.

O próximo item que discutiremos é o item $c$ do bloco "Navegação" e que está relacionado com o critério de análise Ferramentas de acessibilidade. A afirmação é a seguinte: Possibilita a adaptação da tela à leitura e à navegação para diversas necessidades dos usuários. Os resultados verificados foram: 1 participante discordou parcialmente da afirmação, 1 concordou parcialmente com a afirmação e 8 participantes concordaram plenamente com a afirmação.

Em tais resultados, nos chama a atenção o fato que 8 participantes concordaram plenamente com a afirmação. Conforme visto em nossa análise crítica, a única ferramenta de acessibilidade disponibilizada pelo recurso é aquela que possibilita o usuário modificar o tamanho da fonte em apenas uma escala, ou seja, o usuário pode utilizar o tamanho da fonte pequeno ou tamanho da fonte grande. Isto pode sinalizar que os professores ainda não estão atentos a questões relacionadas à educação inclusiva.

O último item que discutiremos é o item $a$ da última parte do questionário, em que os participantes devem refletir sobre o uso dos recursos educacionais abertos digitais. Este item está alinhado com o critério Potencial didático.

A afirmação apresentada é a seguinte: Podem oferecer uma contribuição significativa e relevante à aprendizagem. As respostas dos participantes foram as seguintes: 4 concordaram com a afirmação e outros 6 concordaram totalmente com a afirmação. Portanto, todos os participantes concordaram em alguma medida que o uso de recursos educacionais abertos digitais podem contribuir de forma significativa e relevante para a aprendizagem dos estudantes. 
Para o encerramento deste capítulo, apresentaremos a seguir três dos comentários dos participantes da oficina e que estão registrados no questionário de avaliação, bem como sua transcrição. Além disso, faremos uma breve reflexão sobre tais comentários.

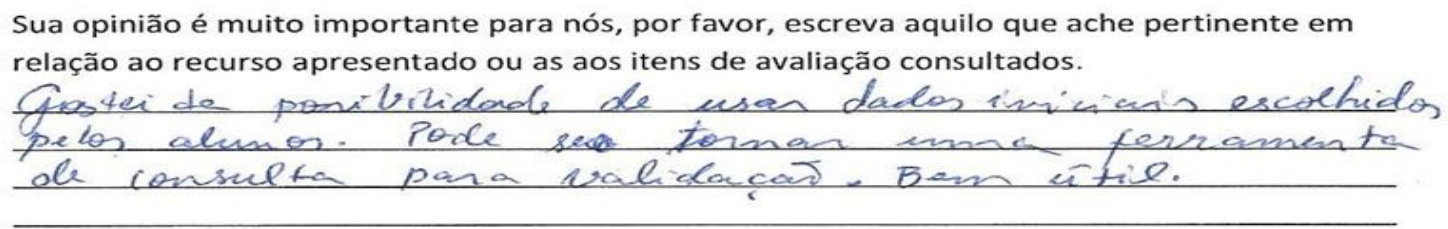

Muito obrigado por sua colaboração!

Figura 24 - Comentário 1

Sua opinião é muito importante para nós, por favor, escreva aquilo que ache pertinente em relação ao recurso apresentado ou as aos itens de avaliação consultados.

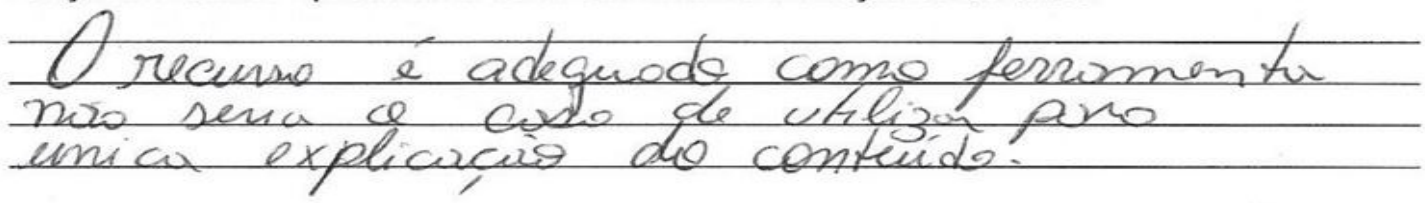

Muito obrigado por sua colaboração!

Figura 25 - Comentário 2

Sua opinião é muito importante para nós, por favor, escreva aquilo que ache pertinente em relação ao recurso apresentado ou as aos itens de avaliação consultados.

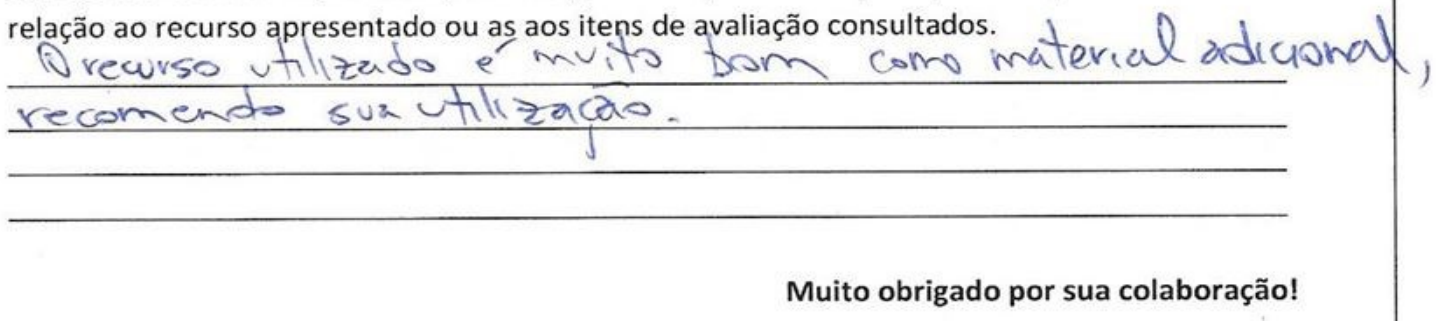

Figura 26 - Comentário 3

A transcrição dos comentários segue abaixo:

Comentário 1: "Gostei da possibilidade de usar dados iniciais escolhidos pelos alunos. Pode se tornar uma ferramenta de consulta para validação. Bem útil”,

Comentário 2: "O recurso é adequado como ferramenta não seria o caso de utilizar para única explicação do conteúdo",

Comentário 3: "O recurso utilizado é muito bom como material adicional, recomendo sua utilização". 
Em relação ao Comentário 1, consideramos pertinente destacar a boa expectativa que o participante apresenta em relação ao recurso, no sentido dos estudantes terem a possibilidade de analisar os dados por eles coletados.

No que se refere ao Comentário 2, entendemos como relevante a preocupação colocada pelo participante em relação ao recurso não vir a se constituir como o único material para a abordagem dos conteúdos. Observamos também que o Comentário 3 mostra-se alinhado com o Comentário 2, pois ainda que o participante considere o recurso como um bom material para o desenvolvimento dos conteúdos, ele o considera como adicional e não como o único material a ser utilizado para tal desenvolvimento.

Corroboramos com as colocações apresentadas nos dois últimos comentários, pois concebemos as TIC como ferramentas capazes de complementar, potencializar e expandir o trabalho que já é desenvolvido pelo professor nos ambientes tradicionais de aprendizagem (suportados por lápis e papel) e não que elas devem suprimir tais ambientes. Afirmamos isto pois, as TIC também possuem potencialidades e limitações, tal como os ambientes tradicionais de aprendizagem possuem as suas.

Nesse sentido, o fundamental é identificarmos de que modo as TIC podem ser integradas nas situações de aprendizagem a fim de que os estudantes tenham a possibilidade de realizar ações que dificilmente seriam reproduzidas nos ambientes tradicionais de aprendizagem e que contribuam efetivamente para o seu aprendizado. 


\section{Conclusão}

Após a análise crítica desenvolvida, podemos tecer as seguintes conclusões a respeito da relevância de cada um dos critérios definidos, as relações existentes entre os mesmos, bem como sobre a dificuldade na aplicabilidade de alguns destes.

Um guia didático bem estruturado aliado a uma alta usabilidade são características que podem inicialmente subsidiar e motivar tanto o professor e o estudante na utilização de um recurso educacional digital. Em relação ao recurso analisado, tais características puderam ser facilmente analisadas por meio dos critérios Guia didático e Usabilidade.

O fato de um recurso mostrar-se estável ou não poderá interferir no engajamento dos alunos na sua utilização, pois, caso o recurso venha a apresentar recorrentes problemas em sua execução de modo que os estudantes tenham que interromper suas atividades ou retornar ao início do recurso para refazer as atividades, poderá eventualmente implicar em uma perda de interesse por parte destes, principalmente pelo fato deles não conseguirem completar as atividades propostas.

Devemos ponderar também que os requisitos técnicos para a execução do recurso exercem um papel importante, já que o fato dele mostrar-se estável ou não durante sua execução é algo que está diretamente associado a tais requisitos. Com relação ao recurso analisado neste trabalho, o critério Estabilidade mostrou-se relevante para a investigação do funcionamento do recurso. No entanto, devido à diversidade de equipamentos já existentes, tais como computadores e notebooks e suas respectivas configurações, acreditamos ser difícil generalizar as conclusões obtidas a partir de tal critério com relação especificamente ao recurso analisado.

No que se refere ao conteúdo que é apresentado em um recurso, entendemos que sua qualidade e consistência são elementos norteadores para a própria construção do recurso, porém, tais características não podem ser consideradas isoladamente de outros critérios e tampouco serem tidas como exclusivamente determinantes para a sua utilização. Até mesmo porque, eventuais equívocos conceituais que são identificados no decorrer da utilização de um recurso podem vir a desencadear discussões a respeito dos conceitos que estão sendo trabalhados, no que pudemos evidenciar e refletir por meio do critério Consistência do conteúdo.

Com respeito à perspectiva epistemológica de um recurso, podemos estabelecer que apesar dela vir a refletir inicialmente uma concepção de ensino-aprendizagem que o(s) 
autor(es) possui(em) e, ainda que tal concepção possa vir a ser distinta daquela que o professor possui, por meio do critério Perspectiva Epistemológica podemos concluir que o preponderante é a forma como o professor utilizará o recurso e, principalmente, as atividades e questionamentos que ele apresentará aos estudantes no decorrer da sua utilização.

Além disso, as categorias estabelecidas (comportamentalista, construtivista e sócio-interacionista) para a investigação da perspectiva epistemológica de um recurso não são excludentes. Com base na análise do recurso que estudamos, acreditamos ser possível, por exemplo, utilizar um recurso por meio de uma abordagem construtivista ou sócio-interacionista ainda que sua perspectiva epistemológica venha a ser comportamentalista.

Neste embate entre o que é proposto pelo recurso e o que é pretendido pelo professor, identificamos a essencialidade e importância do trabalho do professor, por meio do processo de adaptação e modificação de um recurso com base nos objetivos estabelecidos por ele, em relação ao conteúdo de ensino a ser desenvolvido junto com os estudantes.

A investigação do critério Ferramentas de acessibilidade não se constituiu uma tarefa simples, pois acreditamos que tais elementos ainda não são considerados como preponderantes na construção de recursos.

O critério Potencial didático nos possibilitou o estabelecimento de algumas hipóteses sobre as vantagens e desvantagens na utilização do recurso analisado junto com os estudantes. Acreditamos que tal critério possui uma relação estreita com a Consistência do conteúdo, no que supomos a existência de uma dependência entre tais critérios e inclusive tivemos uma certa dificuldade em alguns momentos para decidir se uma certa característica do recurso deveria ser estudada a partir de um critério ou de outro. Quando isso ocorreu optamos por discutir tais características por meio de ambos, abordando o assunto segundo visões que são complementares em nosso ver.

Ainda sobre o Potencial didático de um recurso, compreendemos que tal critério possui uma componente subjetiva, pois determinar se o leque de conceitos e problemas que podem ser explorados por um recurso é amplo ou restrito dependerá não somente do próprio recurso, mas também dos saberes que o professor que pretende utilizá-lo possui. Nesse sentido, um guia didático bem elaborado poderá complementar ou ampliar os saberes do professor de modo que ele possa investigar de forma mais efetiva ou obter uma maior clareza sobre o potencial didático de um recurso.

Considerando-se as especificidades da Estatística e, por conseguinte, do seu ensino-aprendizagem, apresentados e discutidos no capítulo 4, entendemos que o critério Manipulação de dados e representações mostrou-se relevante para a nossa análise, além 
disso, não encontramos dificuldade em investigar o recurso à luz dos elementos estabelecidos na definição deste critério. Por sua própria caracterização, tal critério está diretamente relacionado a outros dois: Consistência do conteúdo e Potencial didático.

No que se refere ao critério Contribuição à cidadania, não tivemos dificuldade em sua aplicação. No entanto, é importante que um recurso mostre-se isento de informações discriminatórias e venha realmente a contribuir para a formação do estudante como cidadão.

Em nosso ver, tal critério pode ser concebido como determinante para a utilização de um recurso, ou seja, a constatação de informações explícitas ou implícitas de caráter discriminatório deverá eliminar a possibilidade de utilização de um recurso, justamente por ferir preceitos fundamentais da sociedade e em alguns casos até mesmo a legislação vigente.

A investigação realizada por meio do critério Conexão com outros recursos nos possibilitou identificar em que momento o recurso poderia ser inserido no planejamento da disciplina, bem como quais materiais poderiam ampliar a sua proposta. A facilidade na aplicação de tal critério em relação ao recurso deu-se principalmente em virtude do ótimo "Guia do Professor" disponibilizado pelo recurso e que nos remete, portanto, ao critério Guia didático.

O critério Licença de uso, abertura e formato técnico nos permitiu investigar elementos que acreditamos serem ainda pouco discutidos ou conhecidos pelos professores. Pontuamos que a licença de uso, abertura e formato técnico de um recurso são determinantes para sua utilização ou não, inclusive após a análise desenvolvida entendemos ser ele o primeiro crivo a ser estabelecido pelo professor quando da pretensão de utilização de um recurso junto com seus estudantes, ainda que tenha sido o último dos critérios a ser definido por nós.

Nesse sentido, torna-se fundamental que a licença de uso de um recurso esteja acessível e clara, a fim de que se possam evitar eventuais problemas de direito autoral e para que o professor possa decidir com clareza sobre a sua utilização ou não.

Considerando-se os elementos apresentados, bem como o objetivo que foi estabelecido para este trabalho, podemos concluir que o conjunto de critérios estabelecido mostrou-se consistente e adequado para a análise do recurso investigado.

Podemos concluir ainda que dependendo da qualidade do recurso e como este será utilizado pelo professor em sala de aula, ele poderá representar uma efetiva contribuição para o ensino-aprendizagem da Estatística no Ensino Médio. Por outro lado, corre-se o risco que se um recurso não é previamente analisado, ele poderá eventualmente favorecer o 
desenvolvimento de conceitos estatísticos incorretos, bem como agravar algumas das dificuldades que já se façam existentes na sua aprendizagem.

Por fim, acreditamos que dentro da pertinência o conjunto de critérios poderá ser, no geral, diretamente aplicável na análise de outros tipos de recursos educacionais digitais concebidos para o ensino-aprendizagem da Estatística, como vídeos, áudios, jogos, entre outros, embora, algumas adaptações e modificações nos critérios serão necessárias. 


\section{Referências}

ALMEIDA, M. E. B. Tecnologias na Educação: dos caminhos trilhados aos atuais desafios. Bolema, Ano 21, no 29, p. 99-129. 2008. Disponível em:

$<$ http://www.periodicos.rc.biblioteca.unesp.br/index.php/bolema>. Acesso em: 03 mar. 2015.

ALMEIDA, M. E. B.; SILVA, M. G. M. O cenário atual do uso de tecnologias digitais da informação e comunicação. In: CGI.br. Pesquisa sobre o uso das tecnologias de informação e comunicação no Brasil: TIC Educação 2010. São Paulo: Comitê Gestor da Internet no Brasil, 2011. p. 27-34. Disponível em: <http://www.cgi.br/>. Acesso em: 15 dez. 2014.

AMIEL, T.; SOARES, T. C. O contexto da abertura: recursos educacionais abertos, cibercultura e suas tensões. Em aberto, v. 28, n. 94, p. 109-122. 2015. Disponível em: $<$ http://emaberto.inep.gov.br/index.php/emaberto/article/viewFile/3895/2275>.

Acesso em: 18 nov. 2015.

AMIEL, T.; OREY, M.; WEST, R. Recursos Educacionais Abertos (REA): modelos para localização e adaptação. Educação Temática Digital, v. 12, n. esp; p. 112-125. 2011. Disponível em: < https://www.fe.unicamp.br/revistas/ged/etd/article/view/2284/2128>. Acesso em: 14 dez. 2015.

BATANERO, C. Joint ICMI-IASE Study: Teaching Statistics in School Mathematics. Challenges for Teaching and Teacher Education. Mesa-redonda. XIII Conferencia Interamericana de Educación Matematica: Belo Horizonte - Brasil, 2011. Disponível em: $<$ http://www.ugr.es/ batanero/pages/ARTICULOS/CIAEM_ICMIStudy_Batanero.pdf $>$. Acesso em: 05 maio 2015.

Didáctica de la Estadística. Grupo de Investigación em Educación Estadística. Departamento de Didáctica de la Matemática. Universidad de Granada. Granada: 2001. Disponível em: <http://www.ugr.es/ batanero/pages/ARTICULOS/didacticaestadistica.pdf $>$. Acesso em: 05 maio 2015.

Significado y Comprensión de las Medidas de Posición Central. UNO, 25, p. 41-58. 2000. Disponível em: <http://www.ugr.es/ batanero/pages/ARTICULOS/isboa.pdf>. Acesso em: 05 maio 2015. 
BATANERO, C.; BURRILL, G.; READING, C. Overview: Challenges for Teaching Statistics in School Mathematics and Preparing Mathematics Teachers. In: BATANERO, Carmen; BURRILL, Gail; READING, Chris (Eds.). Teaching Statistics in School - Mathematics Challenges for Teaching and Teacher Education: A Joint ICMI-IASE Study, p. 407-418. Springer, 2011. Disponível em:

$<$ http://www.ugr.es/ batanero/pages/ARTICULOS/Overview.pdf>. Acesso em: 05 maio 2015.

BATANERO, C.; MERINO, B. C.; DÍAZ, C. Assessing Secondary School Student's Understanding of Averages. In: Proceedings of CERME III. Bellaria - Italia. 2003. Disponível em: <http: http://www.ugr.es/ batanero/pages/english.html>.

Acesso em: 05 maio 2015.

BATANERO, C.; ORTIZ, J. J.; SERRANO, L. Investigación en Didáctica de la Probabilidad. UNO, p. 7-16. 2007. Disponível em:

$<$ http://www.ugr.es/ batanero/pages/ARTICULOS/uNOiNVESTIGACION.pdf>.

Acesso em: 05 maio 2015.

BEN-ZVI, D. Toward Understanding the Role of Technological Tools in Statistics Learning. In: Mathematical Thinking and Learning, 2 (1\&2), p. 127-155. Lawrence Erlbaum Associates, Inc., 2000.

BEN-ZVI, D.; GARFIELD, J. (Eds.). The Challenge of Developing Statistical Literacy, Reasoning and Thinking. Dordrecht: Kluwer Academic Publishers, 2004a.

Research on Statistical Literacy, Reasoning, and Thinking: Issues, Challenges, and Implications. In: BEN-ZVI, D.; GARFIELD, J. (Eds.). The Challenge of Developing Statistical Literacy, Reasoning and Thinking. Dordrecht: Kluwer Academic Publishers, 2004b. p. 397-410.

. Statistical Literacy, Reasoning, and Thinking: Goals, Definitions, and Challenges. In: BEN-ZVI, D.; GARFIELD, J. (Eds.). The Challenge of Developing Statistical Literacy, Reasoning and Thinking. Dordrecht: Kluwer Academic Publishers, 2004c. p. 3-16.

BONILLA, M. H.; PRETTO, N. L. Movimentos colaborativos, tecnologias digitais e educação. Em aberto, v. 28, n. 94, p. 23-40. 2015. Disponível em:

$<$ http://emaberto.inep.gov.br/index.php/emaberto/article/viewFile/3895/2275>.

Acesso em: 18 nov. 2015. 
BRASIL. Guia de livros didáticos: PNLD 2016: Alfabetização Matemática e Matemática: ensino fundamental anos iniciais. Brasilía: MEC/SEB, 2015. p. 59-62. Disponível em: $<$ http://www.fnde.gov.br/programas/livro-didatico/guias-do-pnld/guia-pnld-2016>. Acesso em: 04 set. 2015.

. Ministério da Educação. Secretaria de Educação Básica [autores: Ana Paula Janh et al.]. Formação de Professores do Ensino Médio, Etapa II - Caderno V: Matemática. 49p. Curitiba: UFPR/Setor de Educação: 2014a. Disponível em:

$<$ http://pactoensinomedio.mec.gov.br/index.php?

option=com_content\&view=category\&id=13\&Itemid=117>. Acesso em: 05 mar. 2015.

Guia de livros didáticos: PNLD 2015: matemática: ensino médio. Brasilía: $\mathrm{MEC} / \mathrm{SEB}, 2014 \mathrm{~b}$.

Lei no 13.005, de 25 de junho de 2014. Brasília: Ministério da Casa Civil, 2014c. Disponível em: <http://www.planalto.gov.br/CCIVIL_03/_Ato20112014/2014/Lei/L13005.htm>. Acesso em: 30 junho 2015.

. Lei n ${ }^{\circ}$ 12.796, de 4 de abril de 2013. Brasília: Ministério da Casa Civil, 2013a. Disponível em: < http://www.planalto.gov.br/ccivil_03/_ato2011-2014/2013/lei/112796.htm>. Acesso em: 13 jan. 2015.

Ministério da Educação. Secretaria de Educação Básica. Conselho Nacional da Educação. Câmara Nacional de Educação Básica. Diretrizes Curriculares Nacionais Gerais da Educação Básica. Brasília: Ministério da Educação, Secretaria de Educação Básica, Diretoria de Currículos e Educação Integral, 2013b. p. 145-201.

Resolução CNE/CEB, nº 2/2012. Brasília: Ministério da Educação/Conselho Nacional de Educação/Câmara de Educação Básica, 2012. Disponível em: $<$ http://portal.mec.gov.br/index.php? option $=$ com_content\&view $=$ article $\& i d=12816 \&$ Itemid=866> . Acesso em: 13 jan. 2015.

Resolução CNE/CEB, no 4/2010. Brasília: Ministério da Educação/Conselho Nacional de Educação/Câmara de Educação Básica, 2010. Disponível em: $<$ http://portal.mec.gov.br/index.php? option=com_content\&view=article\&id=12816\&Itemid=866>. Acesso em: 13 jan. 2015.

Parecer CNE/CP, nº 11/2009. Brasília: Ministério da Educação/Conselho Nacional de Educação/Conselho Pleno, 2009a. Disponível em: <http://portal.mec.gov.br/index.php? option $=$ com_content\&view $=$ article\&id=12816\&Itemid=866> . Acesso em: 13 jan. 2015. 
Ministério da Educação. Portaria ${ }^{0}$ 971, de 9 de outubro de 2009. Programa Ensino Médio Inovador, Diário Oficial da República Federativa do Brasil, Brasília, DF, 13 de outubro de 2009b, Seção 1, p. 52. Disponível em:

$<$ http://pactoensinomedio.mec.gov.br/images/pdf/port_971_09102009.pdf $>$. Acesso em: 13 jan. 2015.

PCN+ Ensino Médio: Orientações Educacionais Complementares aos Parâmetros Curriculares Nacionais/Ciências da Natureza, Matemática e suas Tecnologias. Brasília: Ministério da Educação/Secretária da Educação Básica, 2002a. Disponível em: $<$ http://portal.mec.gov.br/seb/arquivos/pdf/CienciasNatureza.pdf $>$. Acesso em: 13 jan. 2015.

Resolução CNE/CP, nº 1/2002. Brasília: Ministério da Educação/Conselho Nacional de Educação/Conselho Pleno, 2002b. Disponível em: <http://portal.mec.gov.br/index.php? option $=$ com_content\&view $=$ article\&id=12816\&Itemid=866> . Acesso em: 13 jan. 2015.

Parecer CNE/CP, no 9/2001. Brasília: Ministério da Educação/Conselho Nacional de Educação/Conselho Pleno, 2001. Disponível em: <http://portal.mec.gov.br/index.php? option=com_content\&view=article\&id=12816\&Itemid=866> . Acesso em: 13 jan. 2015.

Parâmetros Curriculares Nacionais do Ensino Médio: Parte I - Bases Legais. Brasília: Ministério da Educação/Secretaria da Educação Básica, 2000a. Disponível em: $<$ http://portal.mec.gov.br/seb/arquivos/pdf/blegais.pdf>. Acesso em: 13 jan. 2015.

Parâmetros Curriculares Nacionais do Ensino Médio: Parte III - Ciências da Natureza, Matemática e suas Tecnologias. Brasília: Ministério da Educação/Secretaria da Educação Básica, 2000b. Disponível em:

$<$ http://portal.mec.gov.br/seb/arquivos/pdf/ciencian.pdf >. Acesso em: 13 jan. 2015.

Resolução CNE/CEB, no 3/1998. Brasília: Ministério da Educação/Conselho Nacional de Educação/Câmara de Educação Básica, 1998. Disponível em: $<\mathrm{http}: / /$ portal.mec.gov.br/index.php?

option=com_content\&view $=$ article\&id=12816\&Itemid=866>. Acesso em: 13 jan. 2015.

Lei no 9.394, de 20 de dezembro de 1996. Brasília: Ministério da Casa Civil, 1996. Disponível em: <http://www.planalto.gov.br/ccivil_03/leis/19394.htm>. Acesso em: 13 jan. 2015.

CAMPOS, C. R.; WODEWOTZKI, M. L. L.; JACOBINI, O. R. Educação Estatística: teoria e prática em ambientes de modelagem matemática. Belo Horizonte: Autêntica Editora, 2011. p. $9-44$. 
CGI.br (Comitê Gestor da Internet no Brasil). Pesquisa sobre o uso das tecnologias de informação e comunicação nas escolas brasileiras: TIC Educação 2013. $1^{\mathrm{a}}$ ed. São Paulo: Comitê Gestor da Internet no Brasil, 2014. Disponível em: <http://www.cgi.br/>.

Acesso em: 15 dez. 2014.

CHANCE, B. et al. The Role of Technology in Improving Student Learning of Statistics. Technology Innovations in Statistics Education, v.1, n.1. Article 2. p. 1-26. 2007. Disponível em: $<\mathrm{http}: / /$ escholarship.org/uc/item/8sd2t4rr>. Acesso em: 06 maio 2015.

COBO, B.; BATANERO, C. Razonamiento numérico em problemas de promedios. SUMA, p. 79-86, febrero. 2004. Disponível em: <http://revistasuma.es/IMG/pdf/45/079-086.pdf > . Acesso em: 05 maio 2015.

COBO, B.; DÍAZ, C. Media, Mediana y Moda ¿Qué significa esto para los estudiantes de secundaria? $27^{\circ}$ Congreso Nacional de Estadística e Investigación Operativa. Lleida: 2003. Disponível em: $<$ http://www.ugr.es/ batanero/pages/ARTICULOS/SEIOCobo2003.pdf $>$. Acesso em: 05 maio 2015.

CONTRERAS, J. M. et al. El sentido estadístico y su desarrollo. Números: Revista de Didáctica de las Matemáticas, v. 83, p. 7-18, julio. 2013. Disponível em: $<$ http://www.sinewton.org/numeros/numeros/83/Monografico_01.pdf $>$. Acesso em: 05 maio 2015.

DINIZ, C. C. S. TIC no ensino-aprendizagem da Estatística: uma análise crítica de um software que permite um estudo comparativo entre a média e a mediana. In: XIX Encontro Brasileiro de Estudantes de Pós-Graduação em Educação Matemática, 2015, Juiz de Fora MG. Anais do XIX EBRAPEM, 2015. Disponível em: $<$ http://www.ufjf.br/ebrapem2015/files/2015/10/gd12_caio_diniz.pdf $>$. Acesso em: 14 dez. 2015.

EUROPEAN COMISSION. Information Society and Education: Linking European Policies. Luxembourg: Office for Official Publications of the European Communities, 2006. Disponível em: $<\mathrm{http}: / \mathrm{www} . l u . l v /$ materiali/biblioteka/es/pilnieteksti/izglitiba/Information $\% 20$ society $\% 20$ and $\% 20$ education\%20-\%20Linking\%20European\%20Policies.pdf $>$. Acesso em: 05 mar. 2015.

FAGUNDES, L. C.; JOST, D. F. Que contribuições podemos buscar na experiência piloto "Projeto UCA" proposto pelo MEC no Brasil em 2010-2012? In: CGI.br. Pesquisa sobre o uso das tecnologias de informação e comunicação no Brasil: TIC Educação 2012. São Paulo: Comitê Gestor da Internet no Brasil, 2013. p. 71-80. Disponível em: $<$ http://www.cgi.br/>. Acesso em: 15 dez. 2014. 
FERNANDES, J. A.; MORAIS, P. C. Leitura e interpretação de gráficos estatísticos por alunos do nono ano de escolaridade. Educação Matemática Pesquisa, v. 13, n. 1, p. 95-115. 2011. Disponível em: <http://revistas.pucsp.br/index.php/emp/article/view/5282/4052>. Acesso em: 06 maio 2015.

FORBES, S. et al. Use of Data Visualisation in the Teaching of Statistics: a New Zealand Perspective. Statistics Research Education Journal (SERJ), v. 13, n. 2, p. 187-201. 2014. Disponível em: $<$ http://iase-web.org/Publications.php?p=SERJ_issues $>$. Acesso em: 05 maio 2015.

FRANKLIN, C. et al. Guidelines for Assessment Instruction in Statistics Education (GAISE) Report: A Pre-K-12 Curriculum Framework. American Statistical Association (ASA). Alexandria: 2007. Disponível em: <http://www.amstat.org/education/gaise/>. Acesso em: 05 maio 2015.

GAL, I. Statistical Literacy: Meanings, Components, Responsibilities. In: BEN-ZVI, D.; GARFIELD, J. (Eds.). The Challenge of Developing Statistical Literacy, Reasoning and Thinking. Dordrecht: Kluwer Academic Publishers, 2004. p. 47-78.

GARFIELD, J.; BEN-ZVI, D. A Framework for Teaching and Assessing Reasoning about Variability. Statistics Research Education Journal (SERJ), v. 4, n. 1, p. 92-99. 2005. Disponível em: $<$ http://iase-web.org/Publications.php? $\mathrm{p}=$ SERJ_issues $>$. Acesso em: 05 maio 2015.

GITIRANA, V. et al. Média Aritmética no Ensino Fundamental. In: LOPES, C. E.; COUTINHO, C. Q. S.; ALMOULOUD, S. A. (Orgs.). Estudos e Reflexões em Educação Estatística. Campinas: Mercado de Letras, 2010. p.105-131.

GODINO, J. D. et al. Analysis of Two Internet Interactive Applets for Teaching Statistics in Schools. In: Proceedings of the IASE Satellite Conference Statistics Education and the Internet, 2003. Disponível em:

$<$ https://www.stat.auckland.ac.nz/ iase/publications/6/Godino.pdf $>$.

Acesso em: 05 maio 2015.

HOLANDA, A. B. H. Miniaurélio Século XXI Escolar: O minidicionário da língua portuguesa. 4 ed. rev. ampliada. Rio de Janeiro: Nova Fronteira, 2000.

IRDC (Inclusive Design Research Centre). OCAD University. The Floe Inclusive Learning Design Handbook. Disponível em: < http://handbook.floeproject.org/>.

Acesso em: 04 jan. 2016. 
KAWACHI, P. Quality Assurance Guidelines for Open Educational Resources: TIPS Framework Version 2.0. 2014. Disponível em:

$<$ http://cemca.org.in/ckfinder/userfiles/files/TIPS\%20Framework_Version

\%202_0_Low.pdf $>$ Acesso em: 14 dez. 2015.

LÉVY, P. Cibercultura. Tradução: Carlos Irineu da Costa. São Paulo: Editora 34, 1999.

LIMA, A. L. D. TIC na Educação no Brasil: O acesso vem aumentando. E a aprendizagem? In: CGI.br. Pesquisa sobre o uso das tecnologias de informação e comunicação no Brasil: TIC Educação 2011. São Paulo: Comitê Gestor da Internet no Brasil, 2012. 27-34. Disponível em: <http://www.cgi.br/>. Acesso em: 15 dez. 2014.

LIVINGSTONE, S. Critical reflections on the benefits of ICT in education. Oxford Review of Education, 38 (1), p. 9-24. 2012. Disponível em:

$<$ http://eprints.1se.ac.uk/42947/1/_libfile_repository_Content_Livingstone,\%20S_Critical \%20reflections_Livingstone_Critical\%20reflections_2014.pdf $\$$. Acesso em: 05 mar. 2015.

LOPES, C. E. Os desafios para Educação Estatística no Currículo de Matemática. In: LOPES, C. E.; COUTINHO, C. Q. S.; ALMOULOUD, S. A. (Orgs.). Estudos e Reflexões em Educação Estatística. Campinas: Mercado de Letras, 2010. p. 47-64.

. O Ensino da Estatística e da Probabilidade na Educação Básica e a Formação dos Professores. Caderno Cedes, vol. 28, n. 74, p. 57-73, jan-abr. 2008. Disponível em: $<$ http://www.scielo.br/scielo.php?script=sci_arttext\&pid=S0101$32622008000100005 \& \operatorname{lng}=\mathrm{en} \& \mathrm{nrm}=\mathrm{iso} \& \mathrm{t} \operatorname{lng} \mathrm{g}=\mathrm{pt}>$. Acesso em: 06 maio 2015.

LOPES, R. D. et al. O uso dos computadores e da internet em escolas públicas brasileiras. Estudos \& Pesquisas Educacionais, n. 1, maio. 2010. Disponível em: $<$ http://www.fvc.org.br/pdf/artigo-computadores-internet.pdf $>$. Acesso em: 05 mar. 2015.

MAgAlhãeS, M. N.; LIMA, A. C. P. Noções de Probabilidade e Estatística. $7^{\mathrm{a}}$ ed. $2^{\mathrm{a}}$ reimpr. rev. São Paulo: EDUSP, 2013.

MAYÉN, S.; DÍAZ, C.; BATANERO, C. Student's Semiotic Conflicts in the Concept of Median. Statistics Research Education Journal (SERJ), v. 8, n. 2, p. 74-93. 2009. Disponível em: $<$ http://iase-web.org/Publications.php?p=SERJ_issues $>$. Acesso em: 05 maio 2015. 
MENDONÇA, L. O.; LOPES, C. E. O trabalho com Educação Estatística no Ensino Médio em um ambiente de Modelagem Matemática. In: LOPES, C. E.; COUTINHO, C. Q. S.; ALMOULOUD, S. A. (Orgs.). Estudos e Reflexões em Educação Estatística. Campinas: Mercado de Letras, 2010. p. 157-172.

MICHAELIS. Pequeno dicionário inglês-português, português-inglês. São Paulo: Companhia Melhoramentos, 1989.

MICHEL SERRES NO RODA VIDA. Roda Viva. São Paulo: TV CULTURA. Programa de TV. Vídeo disponível em: <https://www.youtube.com/watch?v=3S5ylX64tls>. Acesso em: 10 mar. 2015.

ORTIZ, E. A.; CRISTIA, J. The IDB and technology in education: How to promote effective programs? Inter-American Development Bank (IDB): Education Division (SCL/EDU) - Department of Research and Chief Economist (RES), 2014. Disponível em: $<$ http://idbdocs.iadb.org/wsdocs/getdocument.aspx?docnum=38913794>. Acesso em: 23 jan. 2015.

PFANNKUCH, M.; WILD, C. Towards an understanding of Statistical Thinking. In: BENZVI, D.; GARFIELD, J. (Eds.). The Challenge of Developing Statistical Literacy, Reasoning and Thinking. Dordrecht: Kluwer Academic Publishers, 2004. p. 17-46.

READING, C.; SHAUGHNESSY, J. M. Reasoning about Variability. In: BEN-ZVI, D.; GARFIELD, J. (Eds.). The Challenge of Developing Statistical Literacy, Reasoning and Thinking. Dordrecht: Kluwer Academic Publishers, 2004. p. 201-226.

REATEGUI, E.; BOFF, E.; FINCO, M. D. Proposta de Diretrizes para Avaliação de Objetos de Aprendizagem Considerando Aspectos Pedagógicos e Técnicos. RENOTE - Revista Novas Tecnologias na Educação, v.8, n.3, dezembro. 2010. CINTED - UFRGS. Disponível em: < http://seer.ufrgs.br/index.php/renote/article/view/18066/10653>. Acesso em: 22 jun. 2015.

REYES, K. R. Análisis de Recursos en Internet para la enseñanza de la Probabilidad em la Educación Primaria. Tesis de Máster Oficial em Didáctica de la Matemática. Universidad de Granada. Director: José Miguel Contreras. Granada, 2013. Disponível em: $<$ http://www.ugr.es/ batanero/pages/ARTICULOS/karen.pdf>. Acesso em: 05 maio 2015. 
ROSSINI, C.; GONZALES, C. REA: o debate em política pública e as oportunidades para o mercado. In: SANTANA, B.; ROSSINI, C.; PRETTO, N. L. (Orgs.). Recursos Educacionais Abertos: práticas colaborativas e políticas públicas. 1 ed., 1 imp. Salvador: Edufba; São Paulo: Casa da Cultura Digital, 2012. p. 35-69. Disponível em:

$<$ http://www.livrorea.net.br/livro/home.html>. Acesso em: 16 nov. 2015.

SANTANA, M. S. A Educação Estatística com base num ciclo investigativo: um estudo do desenvolvimento do letramento estatístico de estudantes de uma turma do terceiro ano do Ensino Médio. Dissertação de Mestrado Profissional em Educação Matemática. Programa de Pós-Graduação em Educação Matemática da Universidade Federal de Ouro Preto. Ouro Preto, 2011. Disponível em: < http://www.ppgedmat.ufop.br/index.php/producao/dissertacoes $>$. Acesso em: 06 maio 2015.

SANTOS, A. I. Recursos Educacionais Abertos no Brasil: o estado da arte, desafios e perspectivas para o desenvolvimento e inovação. UNESCO - CETIC.br. Tradução: DB Comunicação. São Paulo: Comitê Gestor da Internet no Brasil (CGI.br), 2013. Disponível em: $<$ http://www.cetic.br/media/docs/publicacoes/8/rea-andreia-inamorato.pdf $>$.

Acesso em: 22 jun. 2015.

. Educação Aberta: histórico, práticas e contexto dos recursos educacionais abertos. In: SANTANA, B.; ROSSINI, C.; PRETTO, N. L. (Orgs.). Recursos Educacionais Abertos: práticas colaborativas e políticas públicas. 1 ed., 1 imp. Salvador: Edufba; São Paulo: Casa da Cultura Digital, 2012. p. 71-89. Disponível em: <http://www.livrorea.net.br/livro/home.html $>$. Acesso em: 16 nov. 2015.

SEO, J. A iniciativa "Smart Education": um olhar às escolas do futuro/O uso das TIC na Educação - O caso da República da Coréia. In: CGI.br. Pesquisa sobre o uso das tecnologias de informação e comunicação nas escolas brasileiras: TIC Educação 2013. $1^{\mathrm{a}}$ ed. São Paulo: Comitê Gestor da Internet no Brasil, 2014. p. 93-100. Disponível em: $<$ http://www.cgi.br/>. Acesso em: 15 dez. 2014.

SEVERINO, A. J. Metodologia do Trabalho Científico. $23^{\text {a }}$ ed. rev. e atual. São Paulo: Cortez, 2007.

SIEMENS, G.; TITTENBERGER, P. Handbook of Emerging Technologies for Learning. University of Manitoba, 2009. Disponível em: <http://elearnspace.org/Articles/HETL.pdf $>$. Acesso em: 05 mar. 2015.

SILVEIRA, S. A. Implicações sociais e educacionais dos padrões e formatos abertos. Em aberto, v. 28, n. 94, p. 71-80. 2015. Disponível em:

$<$ http://emaberto.inep.gov.br/index.php/emaberto/article/viewFile/3895/2275>. Acesso em: 18 nov. 2015. 
Formatos abertos. In: SANTANA, B.; ROSSINI, C.; PRETTO, N. L. (Orgs.).

Recursos Educacionais Abertos: práticas colaborativas e políticas públicas. 1 ed., $1 \mathrm{imp}$. Salvador: Edufba; São Paulo: Casa da Cultura Digital, 2012. p. 109-120. Disponível em: $<$ http://www.livrorea.net.br/livro/home.html>. Acesso em: 16 nov. 2015.

TISHKOVSKAYA, S.; LANCASTER, G. A. Statistical Education in the $21^{\text {st }}$ Century: a Review of Challenges, Teaching Innovations and Strategies for Reform. Journal of Statistics Education, v. 20, n. 2, 2012. Disponível em:

$<$ http://www.amstat.org/publications/jse/v20n2/tishkovskaya.pdf>. Acesso em: 05 maio 2015.

TRUCANO, M. Alguns desafios para os formuladores de políticas educativas na era das TIC. In: CGI.br. Pesquisa sobre o uso das tecnologias de informação e comunicação no Brasil: TIC Educação 2011. p. 65-71. São Paulo: Comitê Gestor da Internet no Brasil, 2012. Disponível em: <http://www.cgi.br/>. Acesso em: 15 dez. 2014.

. Knowledge Maps: ICT in Education. Washington, DC: infoDev / World Bank, 2005. Disponível em: <http://www.infodev.org/en/Publication.8.html >. Acesso em: 05 mar. 2015.

UNESCO. ICT Competency Standards for Teachers: Implementation Guidelines Version 1.0. United Kingdom, 2008. Disponível em:

$<$ http://unesdoc.unesco.org/images/0015/001562/156209E.pdf > . Acesso em: 05 mar. 2015.

UNIVERSIDAD DE ALCALÁ DE HENARES. SEÑAS: diccionario para la enseñanza de la lengua española para brasileños. Tradução: Eduardo Brandão e Claudia Berliner. $2^{\mathrm{a}}$ ed. São Paulo: Martins Fontes, 2001.

VALENTE, J. A. (Org.). Computadores e Conhecimento: Repensando a Educação. $2^{\mathrm{a}}$ ed. Campinas: UNICAMP/NIED, 1998. Disponível em: <http://www.nied.unicamp.br/>.

Acesso em: 27 fev. 2015.

. O uso inteligente do computador na Educação. Pátio - revista pedagógica, Ano 1, $\overline{\mathrm{N}^{\circ}}$ 1, p. 19-21. $1997 \mathrm{~b}$.

Tecnologias Digitais da Informação e Comunicação e Currículo: trajetórias convergentes ou divergentes? Departamento de Multimeios, Nied e GGTE da Unicamp e CED da PUC-SP. Disponível em: <http://sinop.unemat.br/v-semi-info-edu/wpcontent/uploads/2013/07/tdic_curriculo_trajetorias.pdf $>$. Acesso em: 05 mar. 2015. 
VALENTE, J. A.; ALMEIDA, F. J. Visão Analítica da Informática na Educação no Brasil: A questão da formação do professor. Revista Brasileira de Informática na Educação Número 1. 1997a. Disponível em: <http://www.br-ie.org/pub/index.php/rbie/issue/view/72>. Acesso: 03 mar. 2015.

VALENTE, J. A.; ALMEIDA, M. E. B. Tecnologias e currículo: trajetórias convergentes ou divergentes? $1^{\text {a }}$ ed. São Paulo: Paulus, 2011.

VOELCKER, M. D. Tecnologias Digitais e a Mudança de Paradigma na Educação: a aprendizagem ativa dos educadores como favorecedora para diferenciação e sustentação da mudança. Tese de Doutorado em Informática na Educação. Programa de Pós-Graduação em Informática na Educação da Universidade Federal do Rio Grande do Sul. Porto Alegre, 2012. Disponível em: <http://www.pgie.ufrgs.br/index.php>. Acesso em: 05 mar. 2015.

WILEY, D. A. Connecting learning objects to instructional design theory: A definition a metaphor, and a taxonomy. 2001. Disponível em:

$<$ http://reusability.org/read/chapters/wiley.doc >. Acesso em: 29 jun. 2015.

WILSON, C. et al. Alfabetização midiática e informacional: currículo para formação de professores. Brasília: UNESCO, UFMT, 2012. Disponível em: http: $<$ http://www.unesco.org/new/pt/brasilia>. Acesso em: 03 mar. 2015.

ZUFFO, D. A formação de professores para o uso das tecnologias educacionais: o que apontam as teses e dissertações defendidas no Brasil no período de 2003 a 2008. Dissertação de Mestrado em Educação. Programa de Pós-Graduação em Educação da Pontifícia Universidade Católica do Paraná. Curitiba, 2011. Disponível em:

$<$ http://www.pucpr.br/posgraduacao/educacao/tesesdissertacoes.php $>$. Acesso em: 04 mar. 2015. 


\section{APÊNDICES}




\section{APÊNDICE A - Catálogo de Recursos Educacionais Abertos (REA) para o ensino-aprendizagem da Probabilidade e Estatística no Ensino Médio alocados nos repositórios Conteúdos Digitais para o ensino e aprendizagem de Matemática e Estatística (CDME) e Coleção Matemática Multimídia (M3)}

Tabela 1 - Catálogo de REA para o ensino-aprendizagem de Probabilidade e Estatística do repositório CDME

\begin{tabular}{|c|c|c|c|c|}
\hline Código & Nome & Tipo & Tema & Conteúdos abordados \\
\hline CDME-1 & $\begin{array}{l}\text { Estatística das letras } \\
\text { e palavras }\end{array}$ & $\mathrm{S}$ & $\mathrm{E}$ & $\begin{array}{l}\text { Distribuições de frequências; Variáveis qualitativas; } \\
\text { Variáveis quantitativas; Histogramas; Média; Mediana; } \\
\text { Moda; Variância; Desvio Padrão; Mineração de textos; } \\
\text { Linguística Computacional }\end{array}$ \\
\hline CDME-2 & Rodas da fortuna & $\mathrm{S}$ & P-E & $\begin{array}{l}\text { Simulação; Distribuições de frequências; Histogramas; } \\
\text { Probabilidade; Método de Monte Carlo; Números } \\
\text { Aleatórios; Números Pseudoaleatórios; Congruência de } \\
\text { Números Inteiros; A agulha de Buffon. }\end{array}$ \\
\hline CDME-3 & $\begin{array}{l}\text { Distribuição de } \\
\text { frequências e seus } \\
\text { gráficos }\end{array}$ & $\mathrm{S}$ & $\mathrm{E}$ & $\begin{array}{l}\text { Distribuições de frequências; Variáveis qualitativas; } \\
\text { Variáveis quantitativas discretas e contínuas; Histogramas. }\end{array}$ \\
\hline CDME-4 & $\begin{array}{l}\text { Pesquisas estatísticas } \\
\text { no dia-a-dia }\end{array}$ & TE & E & Pesquisas estatísticas; Pesquisas por amostragem; Censos. \\
\hline CDME-5 & Medidas de posição & $\mathrm{S}$ & E & Média; Mediana; Moda; Assimetria; Valores atípicos. \\
\hline CDME-6 & $\begin{array}{l}\text { Medidas de } \\
\text { dispersão }\end{array}$ & $\mathrm{S}$ & $\mathrm{E}$ & $\begin{array}{l}\text { Desvio médio absoluto; Variância; Desvio Padrão; } \\
\text { Coeficiente de variação. }\end{array}$ \\
\hline CDME-7 & $\begin{array}{l}\text { Probabilidade: dois } \\
\text { dados }\end{array}$ & $\mathrm{S}$ & $\mathrm{P}$ & $\begin{array}{l}\text { Experimento aleatório; Eventos equiprováveis; Operações } \\
\text { com eventos; Probabilidade. }\end{array}$ \\
\hline CDME-8 & $\begin{array}{l}\text { Probabilidade: } \\
\text { eventos } \\
\text { equiprováveis }\end{array}$ & $\mathrm{S}$ & $\mathrm{P}$ & $\begin{array}{l}\text { Experimento aleatório; Eventos equiprováveis; Operações } \\
\text { com eventos; Probabilidade. }\end{array}$ \\
\hline CDME-9 & $\begin{array}{l}\text { Gráficos e suas } \\
\text { escalas }\end{array}$ & $\mathrm{S}$ & $\mathrm{E}$ & Histograma; Gráfico de colunas e de linhas; Escalas. \\
\hline CDME-10 & $\begin{array}{l}\text { Probabilidade: } \\
\text { diagramas de árvore }\end{array}$ & $\mathrm{S}$ & $\mathrm{P}$ & $\begin{array}{l}\text { Teorema da Probabilidade total; Probabilidade condicional; } \\
\text { Diagrama de árvore. }\end{array}$ \\
\hline CDME-11 & $\begin{array}{l}\text { Conhecendo o } \\
\text { boxplot }\end{array}$ & $\mathrm{S}$ & E & Quartis; Resumo dos cinco números; Boxplot. \\
\hline CDME-12 & $\begin{array}{l}\text { Construindo } \\
\text { boxplots }\end{array}$ & $\mathrm{S}$ & $\mathrm{E}$ & Quartis; Resumo dos cinco números; Boxplot. \\
\hline CDME-13 & $\begin{array}{l}\text { Probabilidade: } \\
\text { lançamento de dados }\end{array}$ & $\mathrm{S}$ & $P$ & Experimento aleatório; Contagem; Probabilidade. \\
\hline CDME-14 & Faça sua pesquisa & $\mathrm{PE}$ & $\mathrm{E}$ & Pesquisa estatística; Levantamento de dados. \\
\hline
\end{tabular}

I) Siglas: $\mathrm{S}=$ software $; \mathrm{TE}=$ texto explicativo; $\mathrm{PE}=$ planilha eletrônica; $\mathrm{E}=$ Estatística; $\mathrm{P}=$ Probabilidade; $\mathrm{P}-\mathrm{E}$ = Probabilidade e Estatística.

II) Licença de uso: Os recursos estão licenciados sob uma licença Creative Commons Atribuição-NãoComercial-Compartilhalgual 2.5 Brasil. O usuário dos recursos tem permissão para copiar e redistribuir o material em qualquer suporte ou formato. Além disso, é permitido remixar, transformar e criar a partir do material, desde que para fins não-comerciais, atribuindo o devido crédito ao autor da obra, e, caso o usuário modifique os materiais, deverá compartilhá-los sob a mesma licença. 
Observação: os códigos de identificação foram criados por nós, e, portanto, não se aplicam a nenhum tipo de busca no repositório.

Tabela 2 - Catálogo de REA para o ensino-aprendizagem de Probabilidade e Estatística do repositório M3

\begin{tabular}{|c|c|c|c|c|}
\hline Código & Nome & Tipo & Tema & Conteúdos abordados \\
\hline M3-1 & $37 \%$ Namorados & A & $\mathrm{P}$ & Contagem; Probabilidade. \\
\hline M3-2 & Ação, reação e correlação & $\mathrm{V}$ & $\mathrm{E}$ & $\begin{array}{l}\text { Correlação; Estatística Descritiva; Causalidade; Fator } \\
\text { de confusão. }\end{array}$ \\
\hline M3-3 & Apostas no relógio & RJD & P-E & $\begin{array}{l}\text { Independência; Representação gráfica; Interpretação } \\
\text { geométrica de probabilidade. }\end{array}$ \\
\hline M3-4 & Atleticano x Rio-Grandense & $\mathrm{V}$ & E & Média e Desvio Padrão. \\
\hline M3-5 & Atuário e Estatística & $\mathrm{V}$ & E-A & Matemática; Atuária; Profissão; Estatística. \\
\hline M3-6 & Baralhos e torradas & RJD & $\mathrm{P}$ & $\begin{array}{l}\text { Probabilidade; Experimento; Probabilidade } \\
\text { condicional. }\end{array}$ \\
\hline M3-7 & Brasil x Argentina & $\mathrm{V}$ & $P$ & Probabilidade; Decisão; Análise Subjetiva. \\
\hline M3-8 & Cada gráfico no seu galho & $\mathrm{V}$ & $\mathrm{E}$ & Gráfico de pizza; Gráficos; Gráfico de barras. \\
\hline M3-9 & Caminhões de açúcar & A & $\mathrm{P}$ & Probabilidade; Probabilidade condicional. \\
\hline M3-10 & Cara ou coroa & $\mathrm{V}$ & $\mathrm{P}$ & $\begin{array}{l}\text { Combinação; Problema dos pontos; Probabilidade; } \\
\text { História da Matemática. }\end{array}$ \\
\hline M3-11 & Coisa de passarinho & $\mathrm{V}$ & $P$ & $\begin{array}{l}\text { Probabilidade; Fenômenos aleatórios; Experimentos } \\
\text { equiprováveis. }\end{array}$ \\
\hline M3-12 & Coisas do amor & $\mathrm{V}$ & $\mathrm{P}$ & Probabilidade condicional. \\
\hline M3-13 & Cozinha científica & $\mathrm{V}$ & $\mathrm{E}$ & $\begin{array}{l}\text { Planejamento de experimentos; Estatística; Ovo de } \\
\text { Colombo. }\end{array}$ \\
\hline M3-14 & Curva do sino & A & P-E & $\begin{array}{l}\text { Estatística; Gaussiana; Probabilidade; Função de } \\
\text { Distribuição de Probabilidade. }\end{array}$ \\
\hline M3-15 & Dados não-transitivos & A & $\mathrm{P}$ & $\begin{array}{l}\text { Probabilidade; Independência de eventos; } \\
\text { Transitividade. }\end{array}$ \\
\hline M3-16 & Dando Ibope & $\mathrm{V}$ & $\mathrm{E}$ & Estatística e Amostragem. \\
\hline M3-17 & $\begin{array}{l}\text { Dobra a língua e coça a } \\
\text { orelha }\end{array}$ & RRE & $\mathrm{E}$ & Elementos de Amostragem; Interpretação de gráficos. \\
\hline M3-18 & Exoplanetas e Probabilidade & A & $\mathrm{P}$ & Probabilidade. \\
\hline M3-19 & $\begin{array}{l}\text { Explorando o jogo do } \\
\text { máximo }\end{array}$ & $\mathrm{S}$ & $\mathrm{P}$ & Jogo; Dados e probabilidade. \\
\hline M3-20 & Fraude 171 & A & $\mathrm{P}$ & Probabilidade; Função exponencial. \\
\hline M3-21 & Grande hotel 2 & $\mathrm{~V}$ & $\mathrm{P}$ & Probabilidade; Probabilidade condicional. \\
\hline M3-22 & $\begin{array}{l}\text { Gráficos estatísticos: barras e } \\
\text { setores }\end{array}$ & $\mathrm{S}$ & $\mathrm{E}$ & $\begin{array}{l}\text { Variáveis quantitativas; Variáveis aleatórias; Gráfico } \\
\text { de setores; Variáveis qualitativas; Gráfico de barras. }\end{array}$ \\
\hline M3-23 & Gravidez na adolescência & A & $\mathrm{E}$ & Estatística e Análise de dados. \\
\hline M3-24 & História da Estatística & A & $\mathrm{E}$ & História da Estatística. \\
\hline M3-25 & História da Probabilidade & A & $\mathrm{P}$ & História da Probabilidade. \\
\hline M3-26 & Jankenpon & RJD & P-E & $\begin{array}{l}\text { Independência; Eventos equiprováveis; Probabilidade; } \\
\text { Representação gráfica; Transitividade; Experimento; } \\
\text { Dados não-transitivos. }\end{array}$ \\
\hline
\end{tabular}




\begin{tabular}{|c|c|c|c|c|}
\hline M3-27 & Jogo das trilhas & RJD & C-P-E & $\begin{array}{l}\text { Permutação e Combinação; Representação gráfica; } \\
\text { Eventos equiprováveis; Probabilidade condicional. }\end{array}$ \\
\hline M3-28 & Jogo das amebas & RJD & $P$ & $\begin{array}{l}\text { Probabilidade condicional; Independência; } \\
\text { Experimento; Probabilidade; Análise de jogos; } \\
\text { Representação gráfica. }\end{array}$ \\
\hline M3-29 & Lembranças de Sofia & $\mathrm{V}$ & $\mathrm{E}$ & Estatística e Amostragem. \\
\hline M3-30 & Máquina do tempo & A & A-P & Probabilidade e Função Exponencial. \\
\hline M3-31 & Massa e idade & A & $\mathrm{E}$ & Média; Limitante; Estimativa. \\
\hline M3-32 & Médias que interessam & A & $\mathrm{E}$ & Médias; Médias ponderadas. \\
\hline M3-33 & $\begin{array}{l}\text { Medidas do corpo - gráficos } \\
\text { univariados }\end{array}$ & $\mathrm{S}$ & $\mathrm{E}$ & Estatística; Gráficos; Corpo humano. \\
\hline M3-34 & Medidas do corpo: boxplot & $\mathrm{S}$ & $\mathrm{E}$ & Quantil; Boxplot; Análise bivariada. \\
\hline M3-35 & $\begin{array}{l}\text { Medidas do corpo: gráfico de } \\
\text { dispersão }\end{array}$ & $\mathrm{S}$ & $\mathrm{E}$ & $\begin{array}{l}\text { Interpretação de gráficos; Coeficiente de correlação } \\
\text { linear; Estatística; Gráficos bivariados; Gráfico de } \\
\text { dispersão. }\end{array}$ \\
\hline M3-36 & Noite do forró & $\mathrm{V}$ & $\mathrm{P}$ & $\begin{array}{l}\text { Eventos complementares; Probabilidade de eventos; } \\
\text { Regra do produto. }\end{array}$ \\
\hline M3-37 & Música quase por acaso & $\mathrm{V}$ & P-E & $\begin{array}{l}\text { Música; Estatística; Probabilidade; Markov; Matrizes; } \\
\text { Probabilidade condicional. }\end{array}$ \\
\hline M3-38 & $\begin{array}{l}\text { O crime da Rua do } \\
\text { Gasômetro }\end{array}$ & $\mathrm{V}$ & $\mathrm{P}$ & Probabilidade condicional; Probabilidade. \\
\hline M3-39 & $\begin{array}{l}\text { O desafio das correlações } \\
\text { espúrias }\end{array}$ & $\mathrm{V}$ & E & Correlações espúrias; Correlação estatística. \\
\hline M3-40 & O jogo de dados de Mozart & $\mathrm{V}$ & M-C-P & Música; Probabilidade; Análise Combinatória. \\
\hline M3-41 & O método de Monte Carlo & RRE & $\mathrm{P}$ & $\begin{array}{l}\text { Razão e Proporção; Probabilidade Geométrica; } \\
\text { Proporcionalidade direta. }\end{array}$ \\
\hline M3-42 & O príncipe de Sofia & $\mathrm{V}$ & $\mathrm{P}$ & Probabilidade; Probabilidade condicional. \\
\hline M3-43 & O que é margem de erro? & A & P-E & Amostragem; Inferência estatística; Margem de erro. \\
\hline M3-44 & Olha o sanduíche & $\mathrm{V}$ & E & Gráfico de frequências e Medidas Resumo. \\
\hline M3-45 & $\begin{array}{l}\text { Olimpíadas: previsões e } \\
\text { apostas }\end{array}$ & A & P-E & Probabilidade e Estatística. \\
\hline M3-46 & População versus Amostra & RRE & $\mathrm{E}$ & Experimento; Estatística; Inferência; Análise de dados. \\
\hline M3-47 & Probabilidade com urnas & $\mathrm{S}$ & $\mathrm{P}$ & $\begin{array}{l}\text { Urnas; Urna sem reposição; Urna de Polya; Urna com } \\
\text { reposição; Probabilidade. }\end{array}$ \\
\hline M3-48 & Prova de alternativas & $\mathrm{V}$ & $\mathrm{P}$ & $\begin{array}{l}\text { Probabilidade condicional; Equiprobabilidade; } \\
\text { Probabilidade. }\end{array}$ \\
\hline M3-49 & Quantos peixes há no lago? & RRE & E & $\begin{array}{l}\text { Estatística; Proporcionalidade direta; Estimação; } \\
\text { Razão e proporção. }\end{array}$ \\
\hline M3-50 & Revendo a moratória & $\mathrm{V}$ & $\mathrm{P}$ & Esperança; Valor esperado; Probabilidade. \\
\hline M3-51 & Sem discriminação & $\mathrm{V}$ & $\mathrm{E}$ & $\begin{array}{l}\text { Amostragem; Paradoxo de Simpson; Correlações; } \\
\text { Estatística. }\end{array}$ \\
\hline M3-52 & Sexo do bebê & A & E & Desvio Padrão; Estatística. \\
\hline M3-53 & Séries temporais & RRE & $\mathrm{E}$ & $\begin{array}{l}\text { Estatística; Interpretação de gráficos e dados; } \\
\text { Experimento. }\end{array}$ \\
\hline M3-54 & Teste de gravidez & $\mathrm{V}$ & $\mathrm{P}$ & $\begin{array}{l}\text { Árvore de probabilidades; Princípio multiplicativo; } \\
\text { Probabilidade condicional. }\end{array}$ \\
\hline M3-55 & Uma aventura de RPG & $\mathrm{V}$ & $P$ & Dados; Probabilidade. \\
\hline M3-56 & Variáveis Antropométricas & RRE & $\mathrm{E}$ & $\begin{array}{l}\text { Correlação; Experimento; Estatística; Representação } \\
\text { gráfica. }\end{array}$ \\
\hline M3-57 & Vulcões e Probabilidade & A & $\mathrm{P}$ & Probabilidade. \\
\hline
\end{tabular}


I) Siglas: $\mathrm{S}=$ software; $\mathrm{V}=$ vídeo; $\mathrm{A}$ = áudio; $\mathrm{RJD}=$ roteiro para realização de jogo didático; $\mathrm{RRE}=$ roteiro para a realização de experimento; $\mathrm{P}=$ Probabilidade; $\mathrm{E}=$ Estatística; $\mathrm{P}-\mathrm{E}=$ Probabilidade e Estatística; $\mathrm{E}-\mathrm{A}=$ Estatística e Atuária; C-P-E = Contagem, Probabilidade e Estatística; A-P = Álgebra e Probabilidade; M-C-P = Música, Contagem e Probabilidade.

II) Licença de uso: Os recursos do repositório estão licenciados sob uma licença Creative Commons. Segundo o repositório, o usuário tem permissão para copiar, distribuir, exibir e executar a obra e criar obras derivadas, mas não é permitido o uso comercial ou o relicenciamento sobre uma licença mais restritiva.

Observação: os códigos de identificação foram criados por nós, e, portanto, não se aplicam a algum tipo de busca no repositório.

Tabela 3 - Quantidade de recursos: tipo de recurso versus repositório

\begin{tabular}{|c|c|c|c|}
\hline Software & CDME & M3 & Total \\
\hline Vídeo & 12 & 6 & 24 \\
\hline Áudio & 0 & 24 & 16 \\
\hline Texto explicativo & 0 & 16 & 1 \\
\hline $\begin{array}{c}\text { Roteiro para a realização } \\
\text { de jogo didático }\end{array}$ & 1 & 0 & 5 \\
\hline $\begin{array}{c}\text { Roteiro para a realização } \\
\text { de experimento }\end{array}$ & 0 & 6 & 6 \\
\hline Planilha eletrônica & 0 & 0 & 1 \\
\hline Total & 1 & 57 & 71 \\
\hline
\end{tabular}

Tabela 4 - Quantidade de recursos: tipo de recurso versus tema

\begin{tabular}{|c|c|c|c|c|}
\hline & Estatística & Probabilidade & $\begin{array}{c}\text { Probabilidade e } \\
\text { Estatística }\end{array}$ & Total \\
\hline Software & 11 & 6 & 1 & 18 \\
\hline Vídeo & 10 & 13 & 1 & 24 \\
\hline Áudio & 5 & 8 & 0 & 16 \\
\hline Texto explicativo & 1 & 0 & 3 & 5 \\
\hline $\begin{array}{c}\text { Roteiro para a realização } \\
\text { de jogo didático }\end{array}$ & 0 & 2 & 0 & 6 \\
\hline $\begin{array}{c}\text { Roteiro para a realização } \\
\text { de experimento }\end{array}$ & 5 & 1 & 0 & 1 \\
\hline Planilha eletrônica & 1 & 0 & 8 & 71 \\
\hline Total & 33 & 30 & & \\
\hline
\end{tabular}

Observação: A coleta de dados nos repositórios e catalogação dos recursos ocorreram nos dias 23 e 24 de junho de 2015. 


\section{APÊNDICE B - Resultado das avaliações dos participantes}

\begin{tabular}{|c|c|c|c|}
\hline \multicolumn{4}{|c|}{ Tabela 5 - Infraestrutura de TIC } \\
\hline & Sim & Não & Total \\
\hline Sala de aula com acesso à internet & 3 & 7 & 10 \\
\hline Lab. de informática com acesso à internet & 8 & 2 & 10 \\
\hline
\end{tabular}

\begin{tabular}{|c|c|c|c|c|c|c|c|}
\hline \multicolumn{8}{|c|}{ Tabela 6 - Conteúdo } \\
\hline & DPL & $\mathrm{DPC}$ & $\mathrm{NN}$ & $\mathrm{CPC}$ & CPL & NSA & Total \\
\hline a) A escolha dos conteúdos é adequada & 0 & 0 & 0 & 6 & 4 & 0 & 10 \\
\hline $\begin{array}{l}\text { b) A sequência em que os conteúdos são } \\
\text { apresentados favorece a progressão da } \\
\text { aprendizagem }\end{array}$ & 0 & 0 & 0 & 6 & 4 & 0 & 10 \\
\hline $\begin{array}{l}\text { c) O tratamento didático do conteúdo pode } \\
\text { ser adaptado a alunos com diferentes estilos } \\
\text { de aprendizagem }\end{array}$ & 0 & 1 & 0 & 4 & 5 & 0 & 10 \\
\hline $\begin{array}{l}\text { d) O tratamento didático do conteúdo pode } \\
\text { ser adaptado a alunos com diferentes níveis } \\
\text { de conhecimento }\end{array}$ & 0 & 0 & 1 & 4 & 5 & 0 & 10 \\
\hline $\begin{array}{l}\text { e) A apresentação do conteúdo é adequada } \\
\text { com o nível proposto }\end{array}$ & 0 & 1 & 0 & 4 & 5 & 0 & 10 \\
\hline $\begin{array}{l}\text { f) A abordagem dos conteúdos pode induzir } \\
\text { algum tipo de erro }\end{array}$ & 2 & 1 & 0 & 5 & 2 & 0 & 10 \\
\hline g) O recurso está livre de erros conceituais & 2 & 2 & 2 & 1 & 3 & 0 & 10 \\
\hline
\end{tabular}

Siglas: DPL $=$ Discordo Plenamente DPC $=$ Discordo Parcialmente; NN $=$ Nem discordo Nem concordo; $\mathrm{CPC}=$ Concordo Plenamente $\mathrm{CPL}=$ Concordo Plenamente; NSA = Não sei avaliar.

\begin{tabular}{|c|c|c|c|c|c|c|c|}
\hline \multicolumn{8}{|c|}{ Tabela 7 - Linguagem e Orientações } \\
\hline & DPL & DPC & $\mathrm{NN}$ & $\mathrm{CPC}$ & CPL & NSA & Total \\
\hline a) A linguagem é apropriada & 0 & 0 & 0 & 2 & 8 & 0 & 10 \\
\hline $\begin{array}{l}\text { b) As orientações e ilustrações oferecidas } \\
\text { são claras, objetivas e suficientes }\end{array}$ & 0 & 0 & 0 & 6 & 4 & 0 & 10 \\
\hline $\begin{array}{l}\text { c) Apresenta material suplementar } \\
\text { interessante }\end{array}$ & 0 & 1 & 0 & 2 & 5 & 2 & 10 \\
\hline
\end{tabular}

Siglas: $\mathrm{DPL}=$ Discordo Plenamente DPC $=$ Discordo Parcialmente $; \mathrm{NN}=$ Nem discordo Nem concordo $; \mathrm{CPC}=$ Concordo Plenamente $; \mathrm{CPL}=$ Concordo Plenamente; NSA = Não sei avaliar. 
Tabela 8 - Interação

DPL DPC NN CPC CPL NSA Total

a) Fornece etapas de teste ou avaliação dos conhecimentos

b) Permite avançar nas etapas ou níveis somente se o aluno dá a resposta esperada

c) O tratamento dado ao erro pode promover a aprendizagem

d) Auxilia para formular e testar hipóteses e realizar comparações

e) Tem flexibilidade em aceitar diferentes: ordens de interações, respostas e estratégias f) $\mathrm{O}$ recurso possibilita que o aluno faça $o$ registro e a consulta às ações

g) Possibilita armazenar as respostas

\begin{tabular}{|c|c|c|c|c|c|c|c|} 
& 0 & 2 & 1 & 1 & 6 & 0 & 10 \\
\hline & 0 & 1 & 1 & 0 & 8 & 0 & 10 \\
\hline & 0 & 1 & 0 & 4 & 5 & 0 & 10 \\
\hline & 0 & 1 & 0 & 4 & 5 & 0 & 10 \\
\hline & 0 & 2 & 2 & 3 & 2 & 1 & 10 \\
\hline & 1 & 1 & 1 & 0 & 7 & 0 & 10 \\
\hline & 1 & 0 & 2 & 0 & 7 & 0 & 10 \\
\hline
\end{tabular}

Siglas: $\mathrm{DPL}=$ Discordo Plenamente $; \mathrm{DPC}=$ Discordo Parcialmente $; \mathrm{NN}=$ Nem discordo Nem concordo CPC $=$ Concordo Plenamente $; \mathrm{CPL}=$ Concordo Plenamente; NSA = Não sei avaliar.

Tabela 9 - Navegação

DPL DPC NN CPC CPL NSA Total

a) O funcionamento dos itens de navegação é adequado

b) Existem rótulos, links, ícones e títulos que orientam a localização e facilitam a navegação

c) Possibilita a adaptação da tela à leitura e à navegação para diversas necessidades dos usuários

\begin{tabular}{|c|c|c|c|c|c|c|c|}
\hline & 0 & 2 & 1 & 4 & 3 & 0 & 10 \\
\hline & 0 & 0 & 0 & 2 & 8 & 0 & 10 \\
\hline & & & & & & & \\
& 0 & 1 & 0 & 1 & 8 & 0 & 10 \\
\hline
\end{tabular}

Siglas: $\mathrm{DPL}=$ Discordo Plenamente DPC $=$ Discordo Parcialmente $; \mathrm{NN}=$ Nem discordo Nem concordo; $\mathrm{CPC}=$ Concordo Plenamente $\mathrm{CPL}=$ Concordo Plenamente; NSA $=$ Não sei avaliar.

Tabela 10 - Aspectos gerais

\begin{tabular}{|l|c|c|c|c|c|c|}
\hline $\begin{array}{l}\text { a) Podem oferecer uma contribuição significativa } \\
\text { e relevante à aprendizagem }\end{array}$ & 0 & 0 & 4 & 6 & 0 & 10 \\
\hline b) Exigem um apoio técnico adicional & 1 & 2 & 4 & 3 & 0 & 10 \\
\hline $\begin{array}{l}\text { c) Requerem uma atualização profissional para } \\
\text { seu uso em sala de aula }\end{array}$ & 1 & 2 & 1 & 5 & 1 & 10 \\
\hline
\end{tabular}


Siglas: $\mathrm{DT}=$ Discordo Totalmente $; \mathrm{D}=$ Discordo $; \mathrm{C}=$ Concordo $; \mathrm{CT}=$ Concordo Totalmente NSA $=$ Não sei avaliar. 
ANEXOS 
ANEXO I - Questionário de avaliação 


\section{Questionário ao Professor}

1. Com respeito à infraestrutura da escola na qual possui maior carga didática, sinalize do que sua escola dispõe.

Sala de aula com acesso à Internet

Laboratório de informática com acesso à Internet

2. Gostaríamos agora de perguntar-lhe sobre diversos aspectos do recurso apresentado, por favor, indique seu grau de concordância com as afirmações a seguir? Por favor, marque apenas uma alternativa em cada caso.

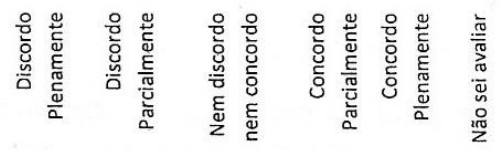

\section{Conteúdo}

a) A escolha do conjunto de conteúdos é $\quad \begin{array}{llllll}7 & 7 & 7 & 4\end{array}$ adequada.

b) A sequência em que os conteúdos são apresentados favorece a progressão da aprendizagem.

c) O tratamento didático do conteúdo pode ser adaptado a alunos com diferentes estilos de aprendizagem.

d) O tratamento didático do conteúdo pode ser adaptado a alunos com diferentes níveis de conhecimento.

e) A apresentação do conteúdo é adequada com o nível de escolaridade proposto.

f) A abordagem dos conteúdos pode induzir algum tipo de erro.

g) O recurso está livre de erros conceituais. 


\section{$M 2$}

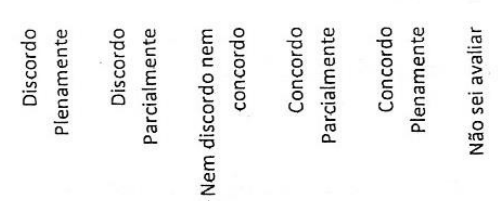

Linguagem e Orientações

a) A linguagem é apropriada.

\begin{tabular}{llllll}
\hline & $\square$ & $\square$ & $\square$ & $\square$ & $\square$
\end{tabular}

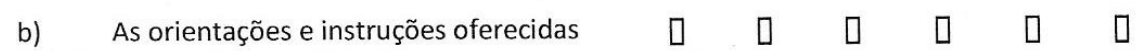
são claras, objetivas e suficientes.

c) Apresenta material suplementar interessante.

\begin{tabular}{llllll}
\hline & $\square$ & $\square$ & $\square$ & $\square$ & $\square$
\end{tabular}

\section{Interação}

a) Fornece etapas de teste ou avaliação dos conhecimentos.

b) Permite avançar nas etapas ou níveis somente se o aluno dá a resposta esperada.

c) O tratamento dado ao erro pode promover a aprendizagem.

d) Auxilia para formular e testar hipóteses e $\quad \begin{array}{llllll}7 & 7 & 7 & 0 & 0 & 0\end{array}$ realizar comparações.

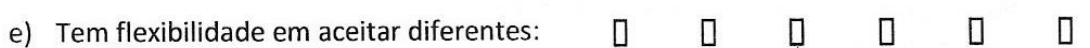
ordens de interações, respostas e estratégias.

f) O recurso possibilita que o aluno faça o $\quad$\begin{tabular}{llllll}
\hline & 0 & 7 & 7 & 0
\end{tabular} registro e a consulta às ações realizadas.

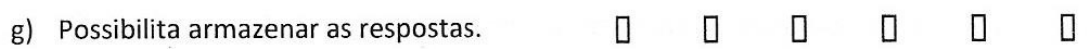




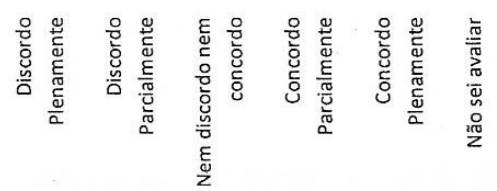

Navegação

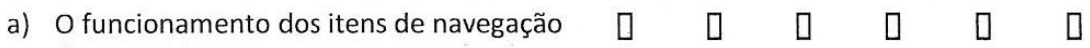
é adequado.

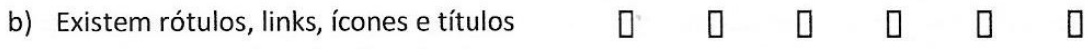
que orientam a localização e facilitam a navegação.

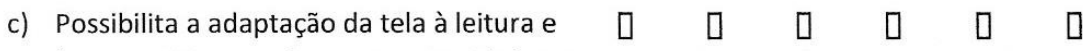
à navegação para diversas necessidades dos usuários.

3. Agora em termos gerais e pensando em qualquer recurso educacional aberto digital, por favor, indique seu grau de concordância com as afirmações a seguir? Por favor, marque apenas uma alternativa em cada caso.

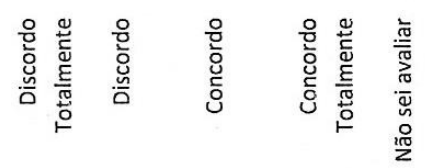
a) Podem oferecer uma contribuição significativa e relevante à aprendizagem.
$\square$
ㄴ
$\square \quad \square$
b) Exigem um apoio técnico adicional
$\begin{array}{lllll}\text { 口 } & 0 & 0 & 0 & 0\end{array}$
口
c) Requerem uma atualização profissional para
ㄴ $\quad \square \quad \square$ seu uso em sala de aula.

Sua opinião é muito importante para nós, por favor, escreva aquilo que ache pertinente em relação ao recurso apresentado ou as aos itens de avaliação consultados. 
ANEXO II - Respostas dos participantes e Termo de Consentimento Livre e Esclarecido 


\title{
Questionário ao Professor
}

1. Com respeito à infraestrutura da escola na qual possui maior carga didática, sinalize do que sua escola dispõe.

Sala de aula com acesso à Internet

Laboratório de informática com acesso à Internet

2. Gostaríamos agora de perguntar-Ihe sobre diversos aspectos do recurso apresentado, por favor, indique seu grau de concordância com as afirmações a seguir? Por favor, marque apenas uma alternativa em cada caso.

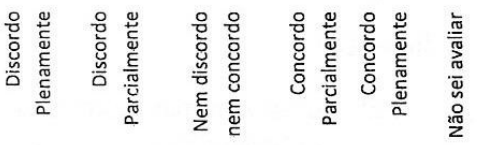

Conteúdo

\begin{abstract}
a) A escolha do conjunto de conteúdos é
\end{abstract} adequada.

b) A sequência em que os conteúdos são apresentados favorece a progressão da aprendizagem.

c) O tratamento didático do conteúdo pode $\quad \begin{array}{llllll}\text { c) } & \text { G }\end{array} \quad$ G ser adaptado a alunos com diferentes estilos de aprendizagem.

d) O tratamento didático do conteúdo pode ser adaptado a alunos com diferentes níveis de conhecimento.

e) A apresentação do conteúdo é adequada com o nível de escolaridade proposto.

f) A abordagem dos conteúdos pode induzir algum tipo de erro.

\begin{tabular}{llllll}
\hline & $\square$ & $\square$
\end{tabular}

\begin{tabular}{llllll}
\hline & $\square$ & $\square$ & $\square$
\end{tabular}

g) O recurso está livre de erros conceituais.

\begin{tabular}{|c|c|c|c|c|}
\hline & ૫ & ( & 圆 & प \\
\hline & Q & Q & 圆 & (] \\
\hline & & 口 & 自 & 0 \\
\hline
\end{tabular}




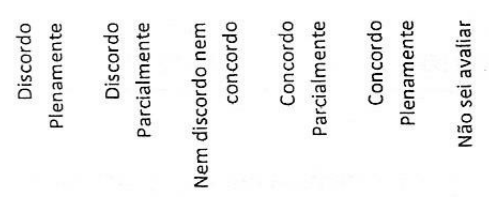

Linguagem e Orientações

a) A linguagem é apropria

b) As orientações e instruções oferecidas são claras, objetivas e suficientes.

c) Apresenta material suplementar interessante.

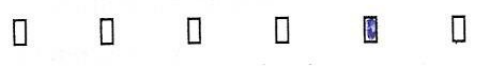

\begin{tabular}{llllll}
\hline & $\square$ & $\square$ & $\square$
\end{tabular}

口 口 口 口 圆 口

Interação

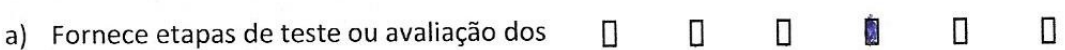
conhecimentos.

b) Permite avançar nas etapas ou níveis somente se o aluno dá a resposta esperada.

c) O tratamento dado ao erro pode promover a aprendizagem.

d) Auxilia para formular e testar hipóteses e $\left.\quad \begin{array}{llllll} & 0 & 0 & 0\end{array}\right]$ realizar comparações.

e) Tem flexibilidade em aceitar diferentes: $\quad \begin{array}{llllll}\text { G } & \text { G }\end{array}$ ordens de interações, respostas e estratégias.

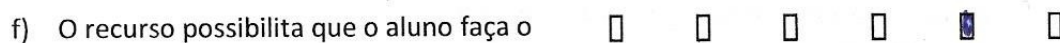
registro e a consulta às ações realizadas.

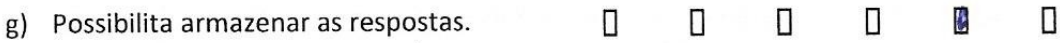




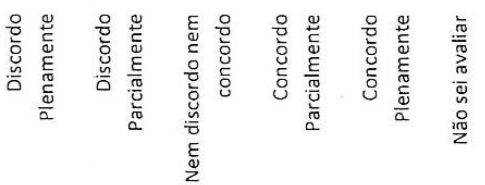

\section{Navegação}

a) O funcionamento dos itens de navegação é adequado.

$$
\text { 口 }
$$

$\square$

$\square$

圆

b) Existem rótulos, links, ícones e títulos que orientam a localização e facilitam a navegação.

c) Possibilita a adaptação da tela à leitura e à navegação para diversas necessidades ○ $\quad \square \quad \square \quad 0 \quad 0$ dos usuários.

3. Agora em termos gerais e pensando em qualquer recurso educacional aberto digital, por favor, indique seu grau de concordância com as afirmações a seguir?

Por favor, marque apenas uma alternativa em cada caso.

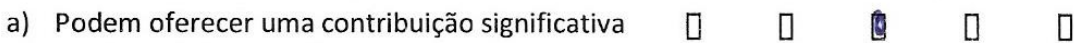
e relevante à aprendizagem.

b) Exigem um apoio técnico adicional

c) Requerem uma atualização profissional para seu uso em sala de aula. 


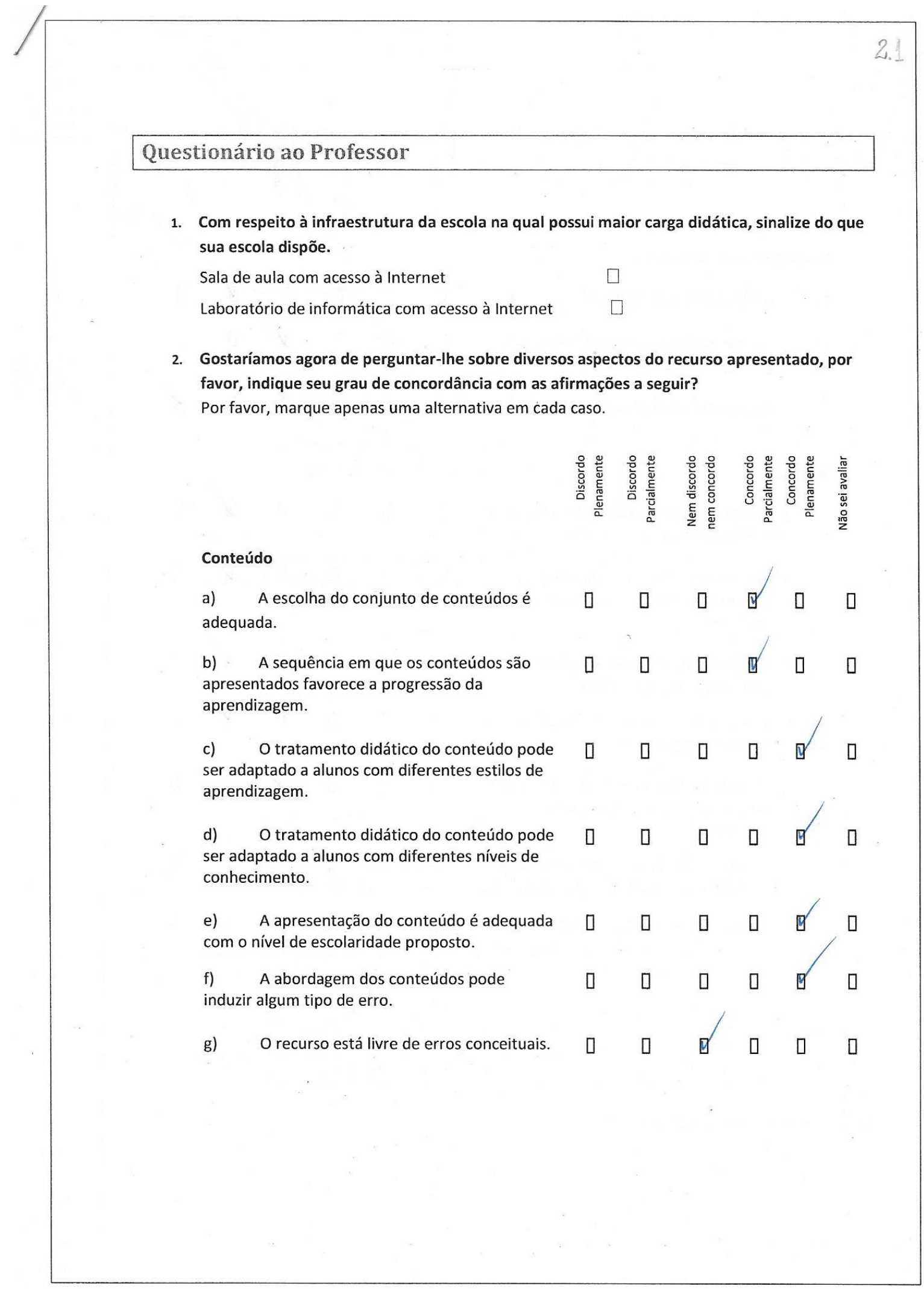


Linguagem e Orientações

a) A linguagem é apropriada.

b) As orientações e instruções oferecidas são claras, objetivas e suficientes.

c) Apresenta material suplementar interessante.

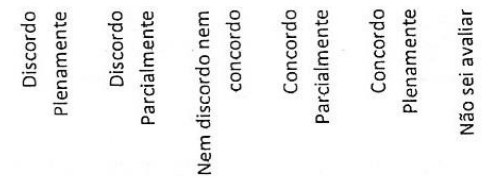

Interação

a) Fornece etapas de teste ou avaliação dos conhecimentos.

b) Permite avançar nas etapas ou níveis somente se o aluno dá a resposta esperada.

c) O tratamento dado ao erro pode promover a aprendizagem.

$\begin{array}{lllll}0 & 0 & 0 & 0 & 0\end{array}$ $\begin{array}{lllll} & 0 & 0 & 0 & 0\end{array}$

$\begin{array}{lllll}7 & 0 & 0\end{array}$

Auxilia para formular e testar hipóteses e realizar comparações.

$\begin{array}{lllll} & 0 & 0 & 0 & 0\end{array}$

$\begin{array}{llllll}7 & 0 & 0 & 0 & \mathbb{8}\end{array}$

$\left.\begin{array}{lllll} & 0 & 0 & 0 & 0\end{array}\right]$

(1)

) Tem flexibilidade em aceitar diferentes: ordens de interações, respostas e estratégias.

f) $O$ recurso possibilita que o aluno faça o registro e a consulta às ações realizadas.

g) Possibilita armazenar as respostas. 


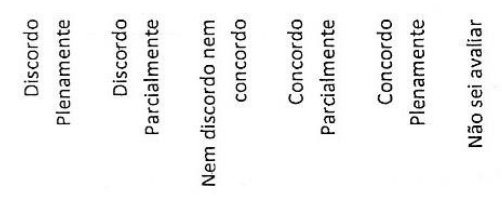

Navegação

a) O funcionamento dos itens de navegação é adequado.

b) Existem rótulos, links, ícones e títulos que orientam a localização e facilitam a navegação.

c) Possibilita a adaptação da tela à leitura e à navegação para diversas necessidades

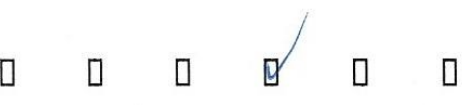

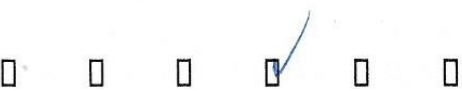
dos usuários.

3. Agora em termos gerais e pensando em qualquer recurso educacional aberto digital, por favor, indique seu grau de concordância com as afirmações a seguir? Por favor, marque apenas uma alternativa em cada caso.

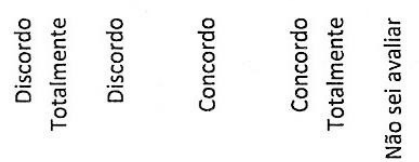

a) Podem oferecer uma contribuição significativa $\begin{array}{lllll}0 \quad 0 \quad 0 \quad 0 & 0\end{array}$ e relevante à aprendizagem.

b) Exigem um apoio técnico adicional

c) Requerem uma atualização profissional para seu uso em sala de aula.

Sua opinião é muito importante para nós, por favor, escreva aquilo que ache pertinente em relação ao recurso apresentado ou as aos itens de avaliação consultados.

A dinämica do recurbo é bem interessante
faltow apenas explorá-lo melhor para ter uma
opniäs maib detalhada.


Questionário ao Professor

1. Com respeito à infraestrutura da escola na qual possui maior carga didática, sinalize do que sua escola dispõe.

Sala de aula com acesso à Internet ه

Laboratório de informática com acesso à Internet

2. Gostaríamos agora de perguntar-Ihe sobre diversos aspectos do recurso apresentado, por favor, indique seu grau de concordância com as afirmações a seguir?

Por favor, marque apenas uma alternativa em cada caso.

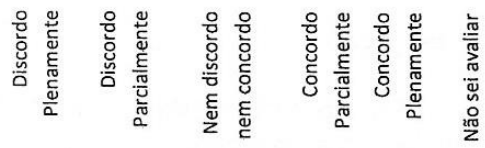

\section{Conteúdo}

a) A escolha do conjunto de conteúdos é adequada.

b) A sequência em que os conteúdos são apresentados favorece a progressão da aprendizagem.

c) O tratamento didático do conteúdo pode ser adaptado a alunos com diferentes estilos de aprendizagem.

d) O tratamento didático do conteúdo pode ser adaptado a alunos com diferentes níveis de

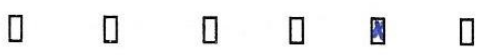
conhecimento.

e) A apresentação do conteúdo é adequada com o nível de escolaridade proposto.

f) A abordagem dos conteúdos pode induzir algum tipo de erro.

g) O recurso está livre de erros conceituais.

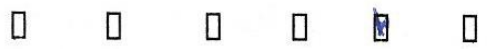

\begin{tabular}{lllll}
\hline & $\square$ & $\square$
\end{tabular}$\quad \square$

\begin{tabular}{llllll}
\hline & $\square$ & $\square$ & $\square$ & 0
\end{tabular}

\begin{tabular}{llllll}
\hline & 0 & $\square$ & $\square$ & l
\end{tabular}

口 口 口 目 口

圆 $\quad \begin{array}{lllll}\text { 口 } & \square & \square & \square & \square\end{array}$ 
Linguagem e Orientações

a) A linguagem é apropriada.

b) As orientações e instruções oferecidas são claras, objetivas e suficientes.

c) Apresenta material suplementar interessante.

\begin{tabular}{|c|c|c|c|c|}
\hline 口 & ૫ & ૫ & Q & 固 \\
\hline П & ( & 口 & Q & 娄 \\
\hline & ח & 0 & Q & [ \\
\hline
\end{tabular}

\section{Interação}

a) Fornece etapas de teste ou avaliaç conhecimentos.

b) Permite avançar nas etapas ou níveis somente se o aluno dá a resposta esperada.

c) O tratamento dado ao erro pode promover a aprendizagem.

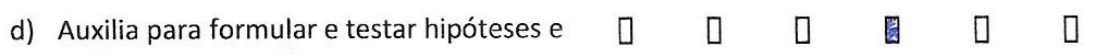
realizar comparações.

e) Tem flexibilidade em aceitar diferentes: ordens de interações, respostas e estratégias.

f) O recurso possibilita que o aluno faça o registro e a consulta às ações realizadas.

g) Possibilita armazenar as respostas. 


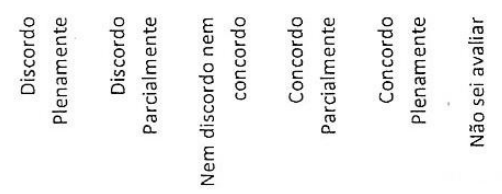

\section{Navegação}

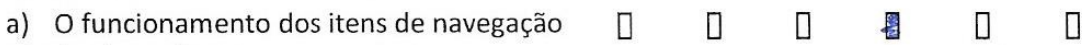
é adequado.

b) Existem rótulos, links, ícones e títulos que orientam a localização e facilitam a navegação.

c) Possibilita a adaptação da tela à leitura e à navegação para diversas necessidades dos usuários.

3. Agora em termos gerais e pensando em qualquer recurso educacional aberto digital, por favor, indique seu grau de concordância com as afirmações a seguir?

Por favor, marque apenas uma alternativa em cada caso.

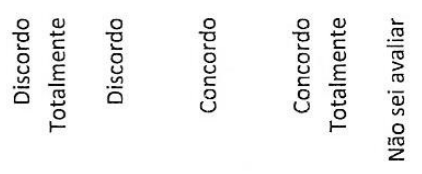

a) Podem oferecer uma contribuição significativa $\quad \begin{array}{llll}7 & 0\end{array}$ e relevante à aprendizagem.

b) Exigem um apoio técnico adicional

算 $\quad 0 \quad 0 \quad 0 \quad 0$

c) Requerem uma atualização profissional para $\quad \begin{array}{lllll}\text { C } & \text { G } & \text { G }\end{array}$ seu uso em sala de aula.

Sua opinião é muito importante para nós, por favor, escreva aquilo que ache pertinente em relação ao recurso apresentado ou as aos itens de avaliação consultados.

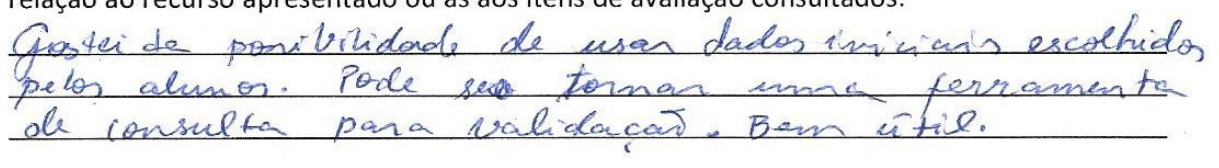


1. Com respeito à infraestrutura da escola na qual possui maior carga didática, sinalize do que sua escola dispõe.

Sala de aula com acesso à Internet

Laboratório de informática com acesso à Internet

2. Gostaríamos agora de perguntar-lhe sobre diversos aspectos do recurso apresentado, por favor, indique seu grau de concordância com as afirmações a seguir?

Por favor, marque apenas uma alternativa em cada caso.

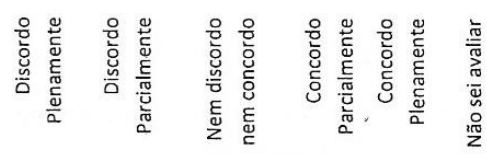

\section{Conteúdo}

a) A escolha do conjunto de conteúdos é $\quad \begin{array}{llllll}7 & \square\end{array} \quad \square \quad \square$ adequada.

b) A sequência em que os conteúdos são apresentados favorece a progressão da aprendizagem.

c) O tratamento didático do conteúdo pode ser adaptado a alunos com diferentes estilos de aprendizagem.

d) O tratamento didático do conteúdo pode ser adaptado a alunos com diferentes níveis de conhecimento.

e) A apresentação do conteúdo é adequada com o nível de escolaridade proposto.

f) A abordagem dos conteúdos pode induzir algum tipo de erro.

g) O recurso está livre de erros conceituais.

$$
\begin{array}{llllll}
\square & \square & \square & \square & \square & \square
\end{array}
$$

\begin{tabular}{llllll}
\hline & $\square$ & $\square$ & $\square$ & 0 & 0
\end{tabular}

\begin{tabular}{llllll}
\hline & 0 & $\square$ & Ө & 0 & 0
\end{tabular} \begin{tabular}{llllll}
\hline & 0 & 0 & 0 & 0 & 0
\end{tabular}

$\begin{array}{llllll}0 & 0 & 0 & 0 & 0 & 0\end{array}$ $\begin{array}{llllll}\square & \square & \square & \square & \square & \square\end{array}$ 


\section{Linguagem e Orientações}

a) A linguagem é apropriada.

b) As orientações e instruções oferecidas são claras, objetivas e suficientes.

c) Apresenta material suplementar interessante.

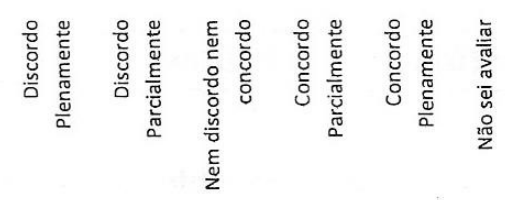

\section{Interação}

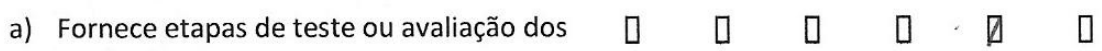
conhecimentos.

\begin{tabular}{llllll}
\hline & $\square$ & $\square$ & 0 & $\square$ & 0
\end{tabular}

․ $\quad \begin{array}{lllll} & \square & \square & \square & \square\end{array}$

\begin{tabular}{llllll}
\hline & $\square$ & $\square$ & $\square$ & $\square$ & $\square$
\end{tabular}

b) Permite avançar nas etapas ou níveis somente se o aluno dá a resposta esperada.

c) O tratamento dado ao erro pode promover a aprendizagem.

d) Auxilia para formular e testar hipóteses e $\quad \begin{array}{llllll}7 & \square & 0 & 0 & \square\end{array}$ realizar comparações.

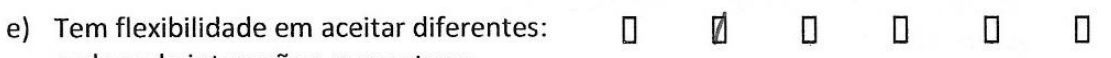
ordens de interações, respostas e estratégias.

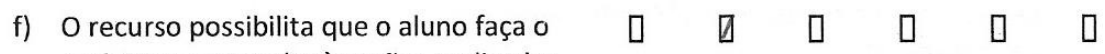
registro e a consulta às ações realizadas.

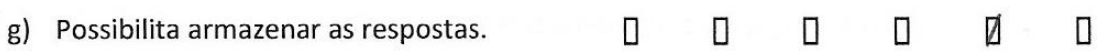




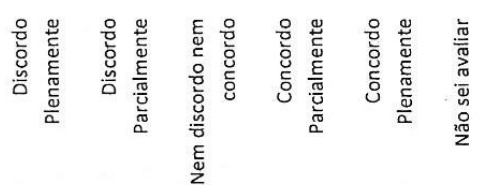

Navegação

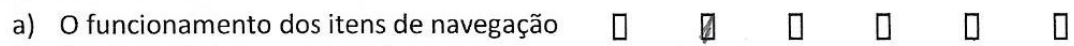
é adequado.

b) Existem rótulos, links, ícones e títulos $\quad \begin{array}{llllll} & \square & \square & \square & \square & \square\end{array}$ que orientam a localização e facilitam a navegação.

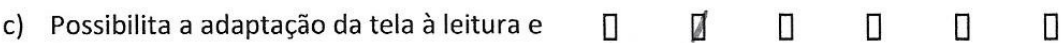
à navegação para diversas necessidades dos usuários.

3. Agora em termos gerais e pensando em qualquer recurso educacional aberto digital, por favor, indique seu grau de concordância com as afirmações a seguir?

Por favor, marque apenas uma alternativa em cada caso.

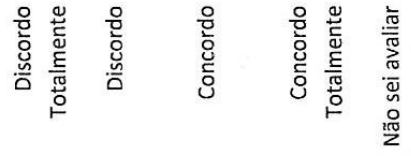

a) Podem oferecer uma contribuição significativa $\quad$\begin{tabular}{lllll}
\hline & 0 & $\square$ & 0
\end{tabular} e relevante à aprendizagem.

b) Exigem um apoio técnico adicional

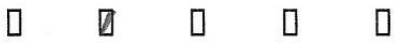

c) Requerem uma atualização profissional para $\quad \begin{array}{llllll}7 & 0 & 7 & 0 & 0\end{array}$ seu uso em sala de aula.

Sua opinião é muito importante para nós, por favor, escreva aquilo que ache pertinente em relação ao recurso apresentado ou as aos itens de avaliação consultados.

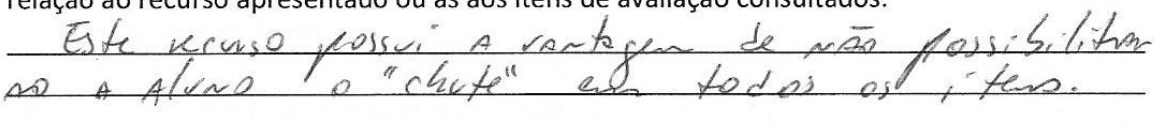


Questionário ao Professor

1. Com respeito à infraestrutura da escola na qual possui maior carga didática, sinalize do que sua escola dispõe.

Sala de aula com acesso à Internet

Laboratório de informática com acesso à Internet

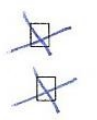

2. Gostariamos agora de perguntar-lhe sobre diversos aspectos do recurso apresentado, por favor, indique seu grau de concordância com as afirmações a seguir?

Por favor, marque apenas uma alternativa em cada caso.

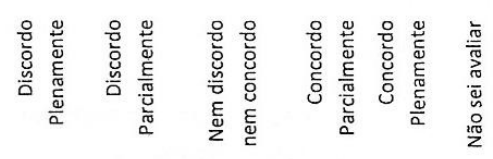

Conteúdo

a) A escolha do conjunto de conteúdos é adequada.

b) A sequência em que os conteúdos são apresentados favorece a progressão da aprendizagem.

c) O tratamento didático do conteúdo pode ser adaptado a alunos com diferentes estilos de aprendizagem.

d) O tratamento didático do conteúdo pode ser adaptado a alunos com diferentes níveis de conhecimento.

e) A apresentação do conteúdo é adequada com o nível de escolaridade proposto.

f) A abordagem dos conteúdos pode induzir algum tipo de erro.

$\begin{array}{lllll}0 & 0 & 0 & 0\end{array}$

ㅁ $\quad$<smiles>CC(C)(C)C(C)(C)C</smiles>

$\begin{array}{llllll}0 & 0 & 0 & 0 & 0\end{array}$

$0 \quad 0 \quad 0 \%(0)$
0

g) O recurso está livre de erros conceituais. $\quad$\begin{tabular}{llllll}
\hline & 4 & 0 & 0
\end{tabular}

(1) 0 ष 0

$\begin{array}{lllll}0 \quad 0 \quad 0 \quad 0 & 0\end{array}$ 


\section{Linguagem e Orientações}

a) A linguagem é apropriada.

$\begin{array}{llll}0 \quad 0 \quad 0 \quad 8 \quad 8 \quad 0 & 8\end{array}$

b) As orientações e instruções oferecidas são claras, objetivas e suficientes.

$\begin{array}{lll}\square \quad \square \quad & \square & \square \quad 0\end{array}$

c) Apresenta material suplementar interessante.

$\begin{array}{llllll}0 & 0 & 0 & \text { e }\end{array}$

Interação

a) Fornece etapas de teste ou avaliação dos conhecimentos.

$\begin{array}{lll}7 & 0\end{array}$

b) Permite avançar nas etapas ou niveis somente se o aluno dá a resposta

$\begin{array}{llll}0 & 0 \quad 0 \quad 0\end{array}$ esperada.

c) O tratamento dado ao erro pode promover a aprendizagem.

口 प 口 व से

d) Auxilia para formular e testar hipóteses e realizar comparações.

\begin{tabular}{lll}
\hline & 0
\end{tabular} 女

e) Tem flexibilidade em aceitar diferentes: ordens de interações, respostas e estratégias.

f) O recurso possibilita que o aluno faça o registro e a consulta às ações realizadas.

g) Possibilita armazenar as respostas.

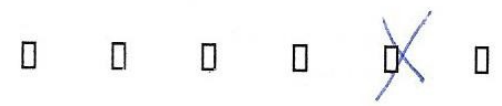

$\begin{array}{lllll}0 & 0 & 0 & 0\end{array}$

\begin{tabular}{llll}
\hline & $0 \quad 0 \quad 0$
\end{tabular} 


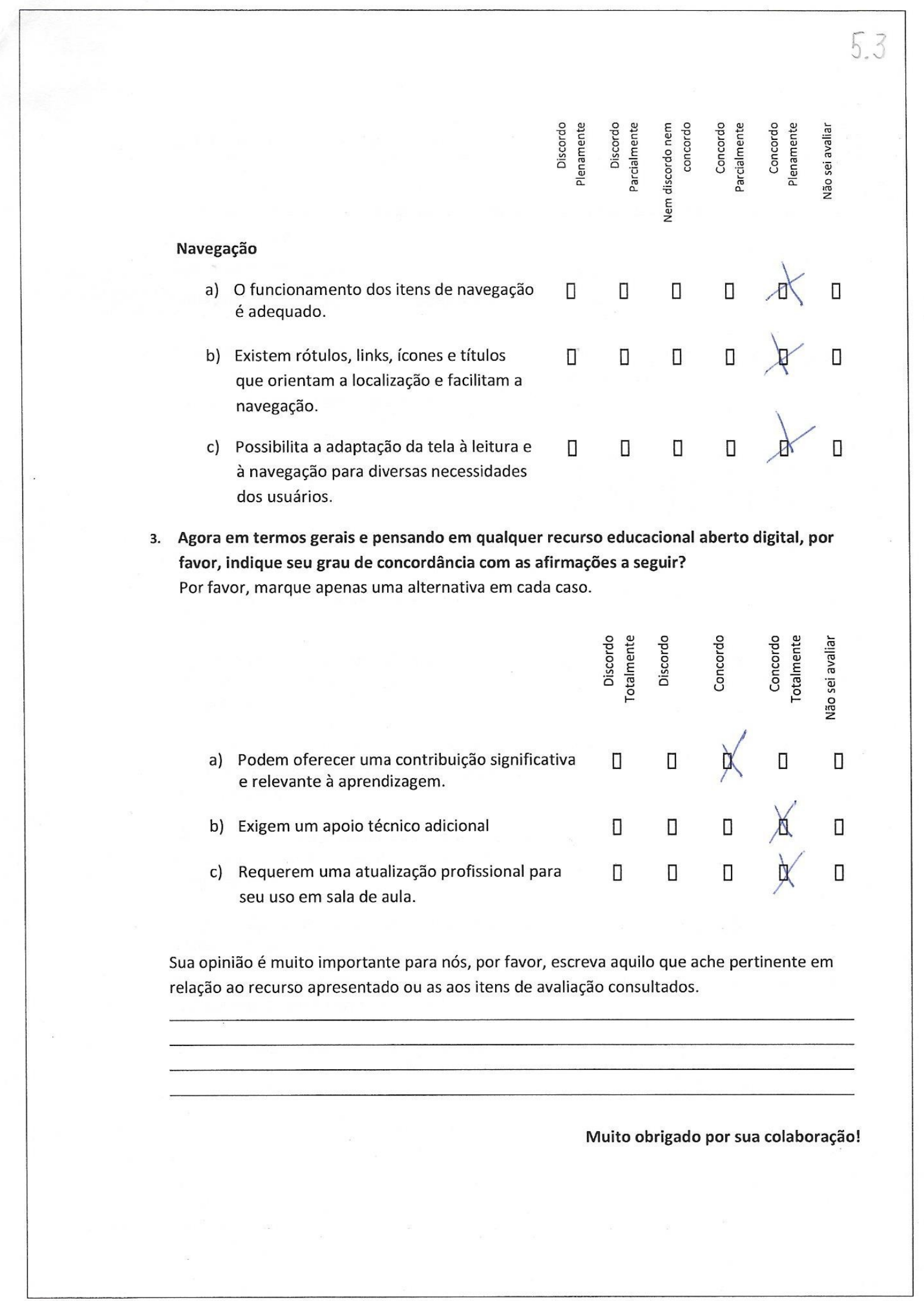




\section{Questionário ao Professor}

1. Com respeito à infraestrutura da escola na qual possui maior carga didática, sinalize do que sua escola dispõe.

Sala de aula com acesso à Internet

四

Laboratório de informática com acesso à Internet

四

2. Gostaríamos agora de perguntar-Ihe sobre diversos aspectos do recurso apresentado, por favor, indique seu grau de concordância com as afirmações a seguir?

Por favor, marque apenas uma alternativa em cada caso.

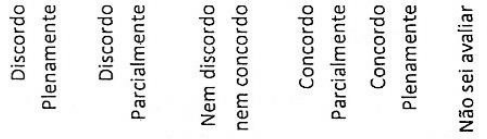

\section{Conteúdo}

a) A escolha do conjunto de conteúdosé adequada.

b) A sequência em que os conteúdos são apresentados favorece a progressão da aprendizagem.

c) O tratamento didático do conteúdo pode ser adaptado a alunos com diferentes estilos de aprendizagem.

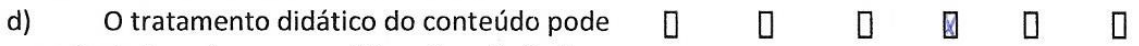
ser adaptado a alunos com diferentes níveis de conhecimento.

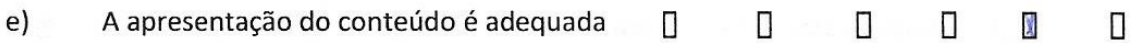
com o nivel de escolaridade proposto.

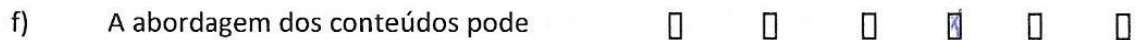
induzir algum tipo de erro.

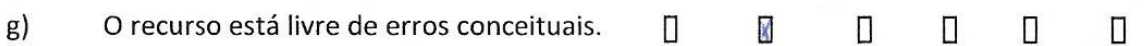




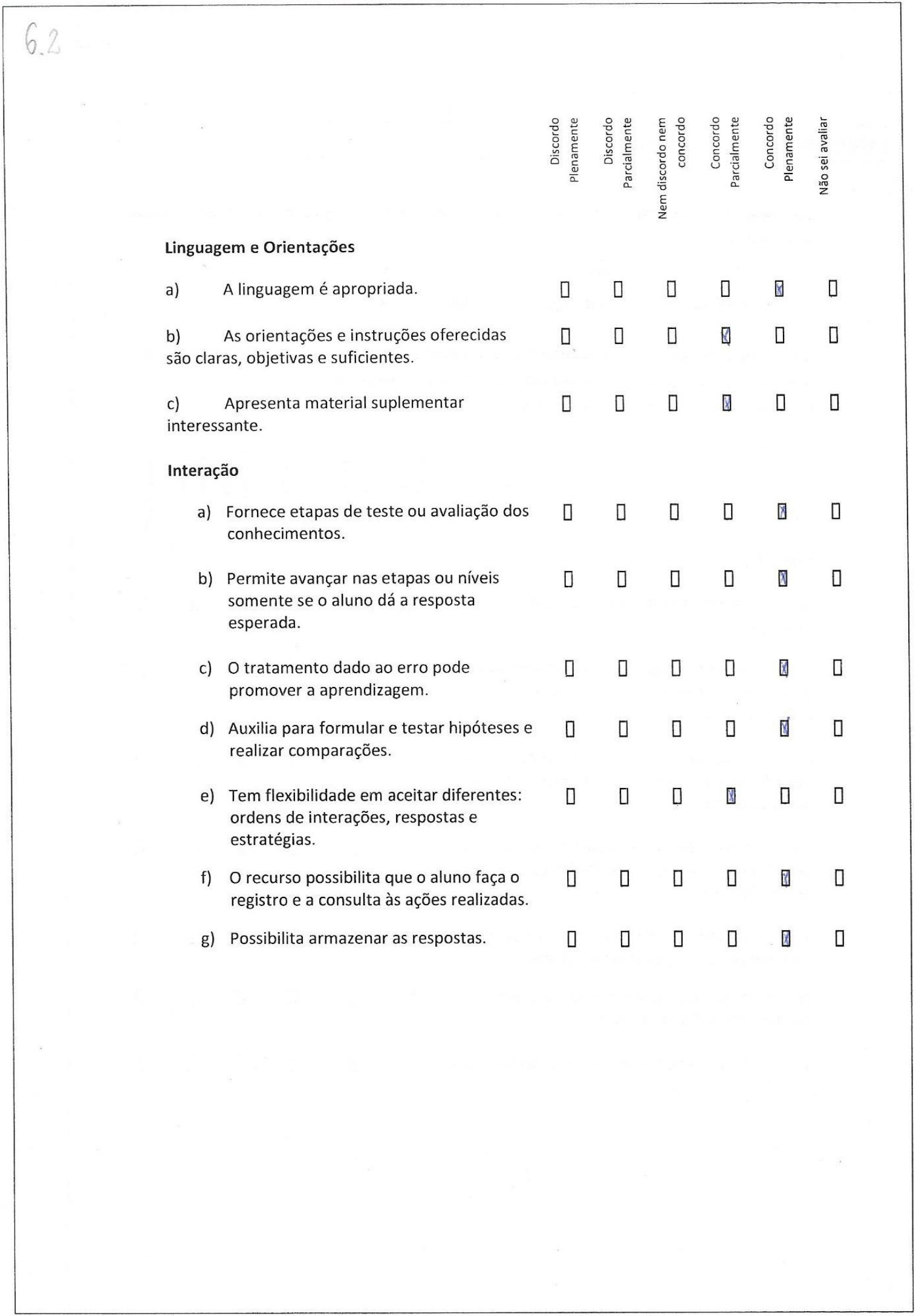




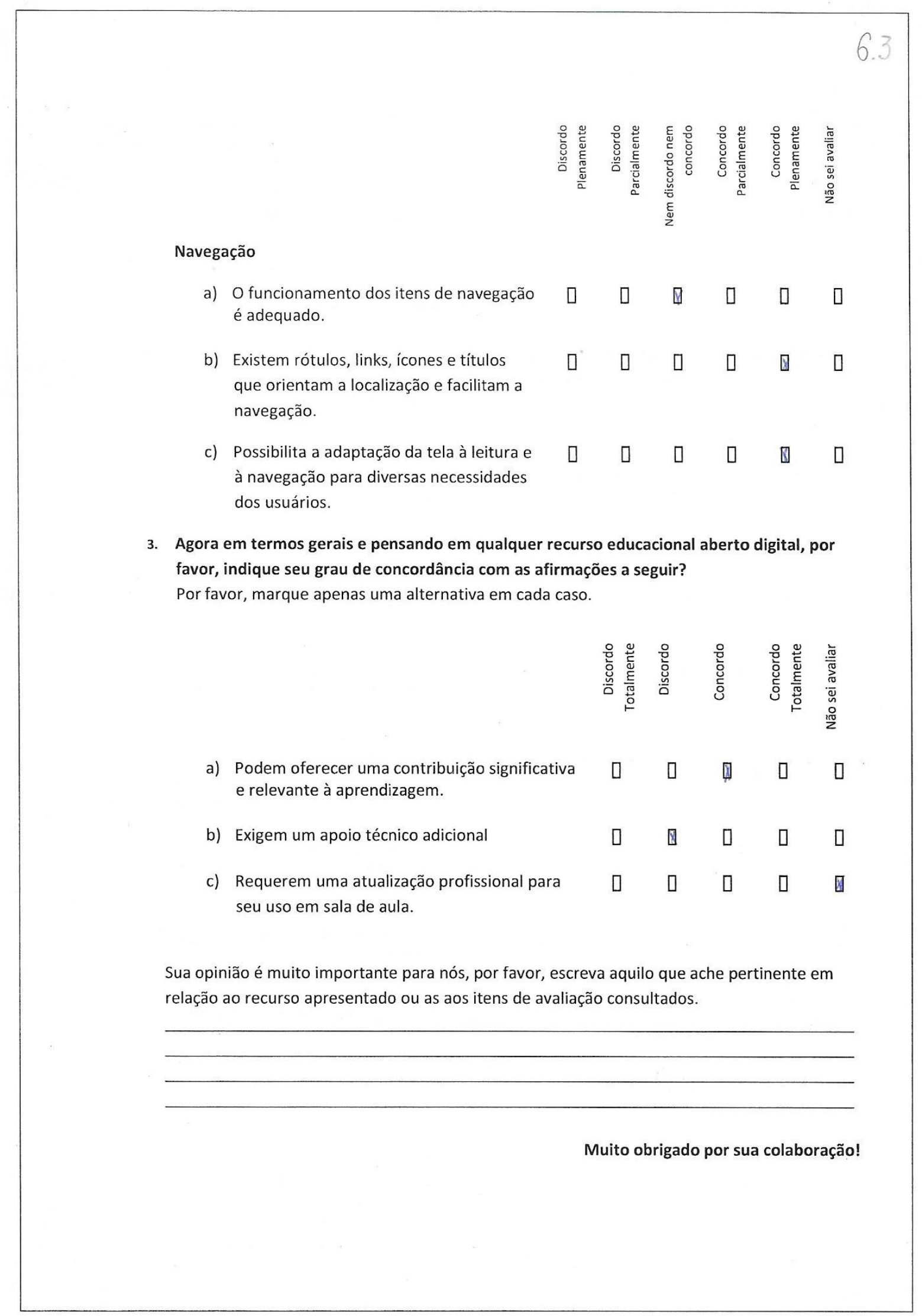


Questionário ao Professor

1. Com respeito à infraestrutura da escola na qual possui maior carga didática, sinalize do que sua escola dispõe.

Sala de aula com acesso à Internet

Laboratório de informática com acesso à Internet

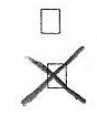

2. Gostaríamos agora de perguntar-Ihe sobre diversos aspectos do recurso apresentado, por favor, indique seu grau de concordância com as afirmações a seguir?

Por favor, marque apenas uma alternativa em cada caso.

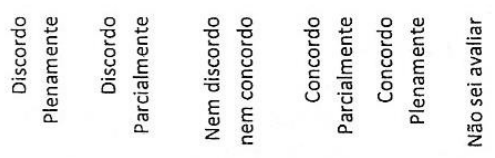

\section{Conteúdo}

a) A escolha do conjunto de conteúdos é adequada.

b) A sequência em que os conteúdos são apresentados favorece a progressão da aprendizagem.

c) O tratamento didático do conteúdo pode ser adaptado a alunos com diferentes estilos de aprendizagem.

d) O tratamento didático do conteúdo pode ser adaptado a alunos com diferentes níveis de conhecimento.

e) A apresentação do conteúdo é adequada com o nível de escolaridade proposto.

f) A abordagem dos conteúdos pode induzir algum tipo de erro.

口 $\quad$

○ \& $0 \quad 0$

ㄴ

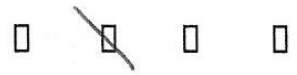

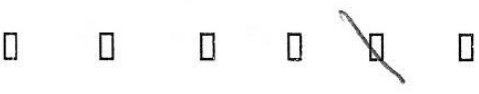

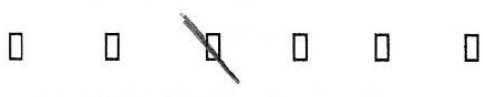

$\begin{array}{lll}0 \quad 0 \quad \square \quad 0 \quad 0 & 0\end{array}$

\begin{tabular}{llllll}
\hline & $\square$ & $\square$ & $\square$
\end{tabular}

g) O recurso está livre de erros conceituais. $\quad \begin{array}{llllll}7 & 0 & 0\end{array}$ 


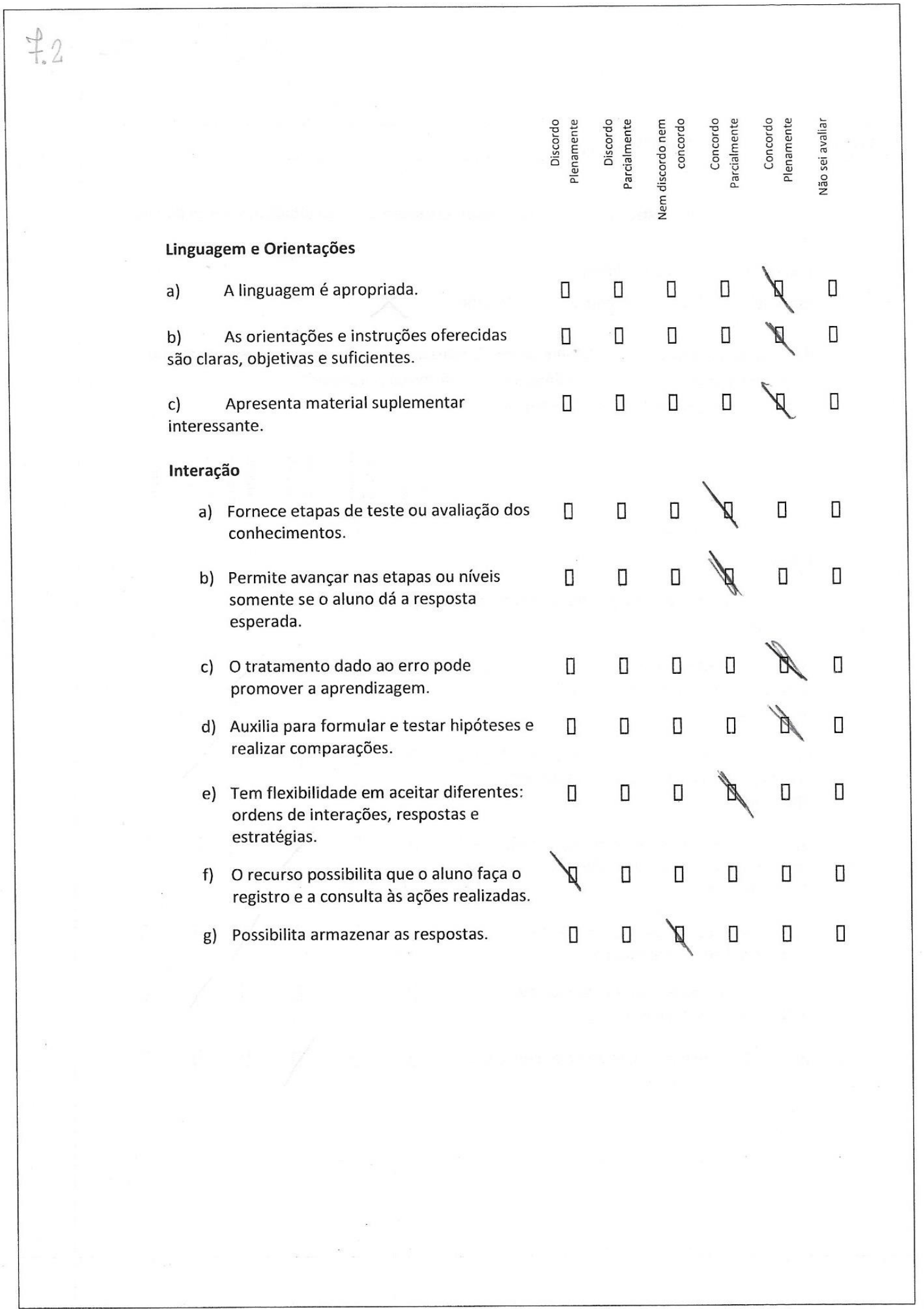




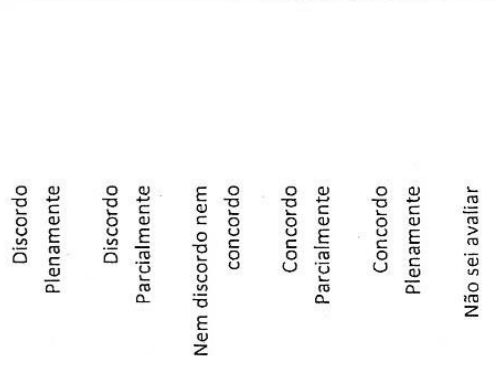

Navegação

a) O funcionamento dos itens de navegação é adequado.

ㄴ $\quad$ ०

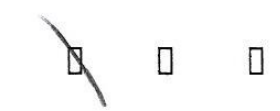

b) Existem rótulos, links, ícones e títulos que orientam a localização e facilitam a

구 $\quad 0$

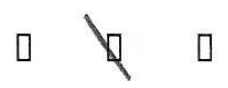
navegação.

c) Possibilita a adaptação da tela à leitura e à navegação para diversas necessidades

$\square \quad 0 \quad 0$<smiles>C=CC</smiles>
dos usuários.

3. Agora em termos gerais e pensando em qualquer recurso educacional aberto digital, por favor, indique seu grau de concordância com as afirmações a seguir? Por favor, marque apenas uma alternativa em cada caso.

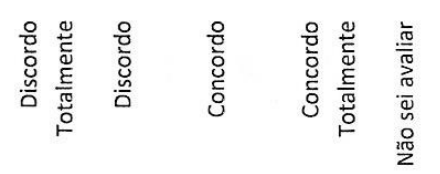

a) Podem oferecer uma contribuição significativa e relevante à aprendizagem.

b) Exigem um apoio técnico adicional

c) Requerem uma atualização profissional para seu uso em sala de aula.

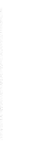


Questionário ao Professor

1. Com respeito à infraestrutura da escola na qual possui maior carga didática, sinalize do que sua escola dispõe.

Sala de aula com acesso à Internet

Laboratório de informática com acesso à Internet ঝ

2. Gostaríamos agora de perguntar-lhe sobre diversos aspectos do recurso apresentado, por favor, indique seu grau de concordância com as afirmações a seguir?

Por favor, marque apenas uma alternativa em cada caso.

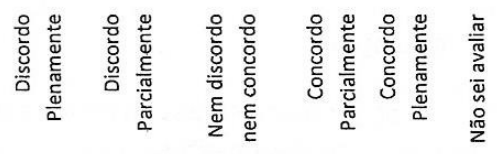

\section{Conteúdo}

a) A escolha do conjunto de conteúdos é $\quad \begin{array}{llllll}7 & 4 & \mathbb{8} & 0\end{array}$ adequada.

b) A sequência em que os conteúdos são $\quad$\begin{tabular}{llllll}
\hline & $\square$ & $\mathbb{K}$ & $\square$ & $\square$
\end{tabular} apresentados favorece a progressão da aprendizagem.

c) O tratamento didático do conteúdo pode ser adaptado a alunos com diferentes estilos de aprendizagem.

d) O tratamento didático do conteúdo pode $\quad$\begin{tabular}{llllll}
\hline & 0 & 0 & 0
\end{tabular} ser adaptado a alunos com diferentes níveis de conhecimento.

e) A apresentação do conteúdo é adequada com o nível de escolaridade proposto.

f) A abordagem dos conteúdos pode induzir algum tipo de erro.

g) O recurso está livre de erros conceituais.

$\begin{array}{llllll}\square & \mathbb{X} & 0 & 0 & 0 & 0 \\ \mathbb{4} & 0 & 0 & 0 & 0 & 0 \\ 0 & 0 & 0 & 0 & \mathbb{K} & 0\end{array}$




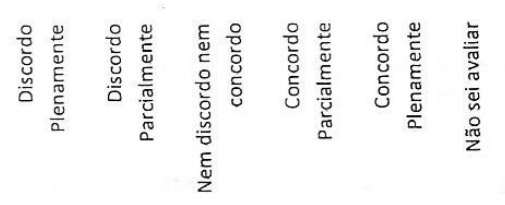

Linguagem e Orientações

a) A linguagem é apropriada. $\quad$\begin{tabular}{llllll}
\hline & $\square$ & $\mathbb{X}$ & $\square$ & $\square$
\end{tabular}

b) As orientações e instruções oferecidas $\quad$\begin{tabular}{llllll}
\hline & 0
\end{tabular} são claras, objetivas e suficientes.

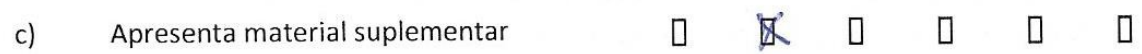
interessante.

Interação conhecimentos.

b) Permite avançar nas etapas ou níveis somente se o aluno dá a resposta esperada.

c) O tratamento dado ao erro pode promover a aprendizagem.

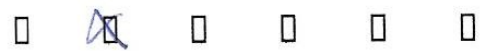

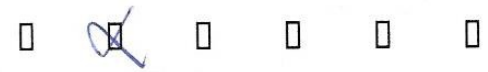

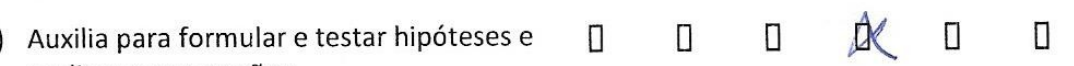
realizar comparações.

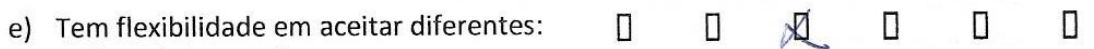
ordens de interações, respostas e estratégias.

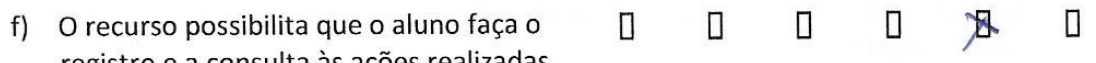
registro e a consulta às ações realizadas.

g) Possibilita armazenar as respostas.

\begin{tabular}{llllll}
\hline & 0 & $\square$ & $\square$ & $\square$
\end{tabular}




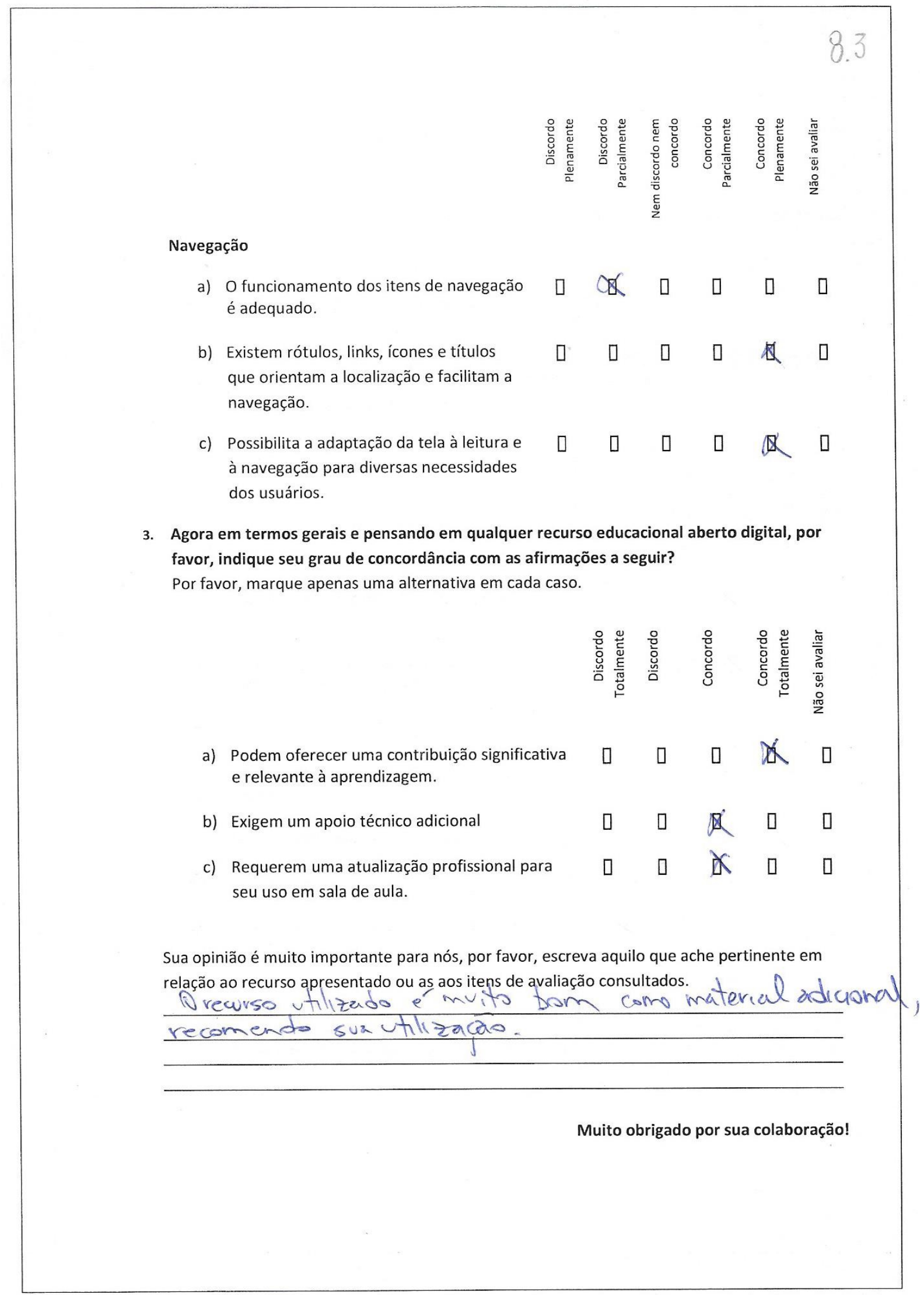


Questionário ao Professor

1. Com respeito à infraestrutura da escola na qual possui maior carga didática, sinalize do que sua escola dispõe.

Sala de aula com acesso à Internet

Laboratório de informática com acesso à Internet

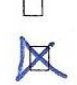

2. Gostaríamos agora de perguntar-Ihe sobre diversos aspectos do recurso apresentado, por favor, indique seu grau de concordância com as afirmações a seguir?

Por favor, marque apenas uma alternativa em cada caso.

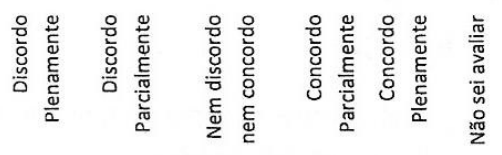

Conteúdo

a) A escolha do conjunto de conteúdos é $\quad \begin{array}{lllll}7 & 0\end{array}$ adequada.

b) A sequência em que os conteúdos são apresentados favorece a progressão da aprendizagem.

c) O tratamento didático do conteúdo pode ser adaptado a alunos com diferentes estilos de aprendizagem.

d) O tratamento didático do conteúdo pode ser adaptado a alunos com diferentes níveis de conhecimento.

e) A apresentação do conteúdo é adequada com o nível de escolaridade proposto.

f) A abordagem dos conteúdos pode induzir algum tipo de erro.

g) O recurso está livre de erros conceituais.

\begin{tabular}{|c|c|c|c|c|}
\hline (? & प & ૫ & П & $\mathbb{Z}$ \\
\hline [? & $\mathbb{Z}$ & Q & [] & ૨ \\
\hline — & ૧ & ૧ & & ૫ \\
\hline ૧ & ૫ & Q & 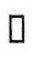 & 边 \\
\hline [ & ( & ० & A & ૫ \\
\hline П & ० & 口 & ( & 及 \\
\hline
\end{tabular}




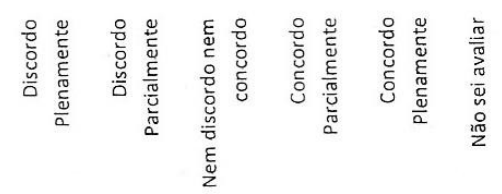

\section{Linguagem e Orientações}

a) A linguagem é apropriada.

b) As orientações e instruções oferecidas são claras, objetivas e suficientes.

c) Apresenta material suplementar interessante.

\begin{tabular}{llllll}
\hline & 0 & 0 & 0 & $\mathbb{2}$
\end{tabular}

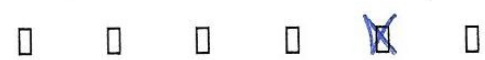

\begin{tabular}{llllll}
\hline & $\square$ & $\square$ & $\square$ & $\mathbb{X}$ & 0
\end{tabular}

Interação

a) Fornece etapas de teste ou avaliação dos $\quad$\begin{tabular}{llllll}
\hline & 0
\end{tabular} conhecimentos.

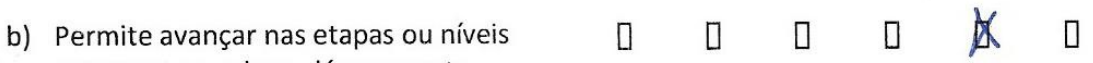
somente se o aluno dá a resposta esperada.

c) O tratamento dado ao erro pode promover a aprendizagem.

\begin{tabular}{llllll}
\hline & 0 & 0 & $\mathbb{8}$ & 0
\end{tabular}

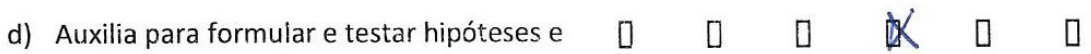
realizar comparações.

e) Tem flexibilidade em aceitar diferentes: ordens de interações, respostas e estratégias.

f) 0 recurso possibilita que o aluno faça o registro e a consulta às ações realizadas.

g) Possibilita armazenar as respostas.

\begin{tabular}{llllll}
\hline & $\square$ & $\square$ & $\square$ & $\mathbb{4}$
\end{tabular}




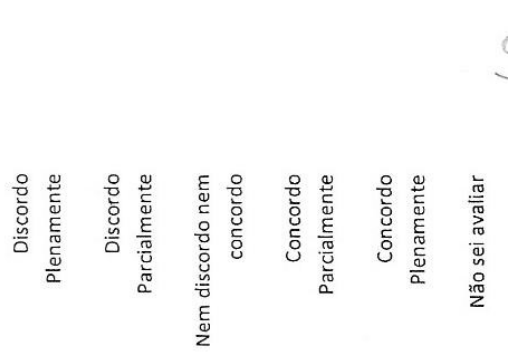

Navegação a) O funcionamento dos itens de navegação
é adequado.

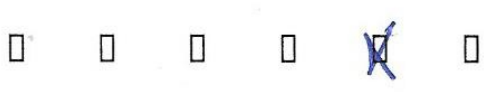

b) Existem rótulos, links, ícones e títulos que orientam a localização e facilitam a navegação.

c) Possibilita a adaptação da tela à leitura e à navegação para diversas necessidades dos usuários.

3. Agora em termos gerais e pensando em qualquer recurso educacional aberto digital, por favor, indique seu grau de concordância com as afirmações a seguir? Por favor, marque apenas uma alternativa em cada caso.

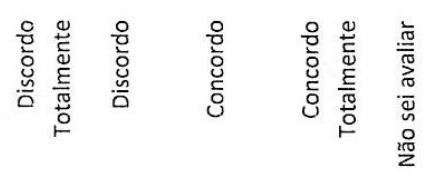

a) Podem oferecer uma contribuição significativa $\quad$\begin{tabular}{lllll}
\hline & $\square$ & $\mathbb{R}$
\end{tabular} e relevante à aprendizagem.

b) Exigem um apoio técnico adicional

$\begin{array}{lllll}0 \quad \mathbb{8} & 0 \quad 0\end{array}$

c) Requerem uma atualização profissional para $\quad$\begin{tabular}{llllll}
\hline & 0 & $\mathbb{A}$
\end{tabular} seu uso em sala de aula.

Sua opinião é muito importante para nós, por favor, escreva aquilo que ache pertinente em relação ao recurso apresentado ou as aos itens de avaliação consultados. 


\section{Questionário ao Professor}

1. Com respeito à infraestrutura da escola na qual possui maior carga didática, sinalize do que sua escola dispõe.

Sala de aula com acesso à Internet

Laboratório de informática com acesso à Internet

2. Gostaríamos agora de perguntar-Ihe sobre diversos aspectos do recurso apresentado, por favor, indique seu grau de concordância com as afirmações a seguir? Por favor, marque apenas uma alternativa em cada caso.

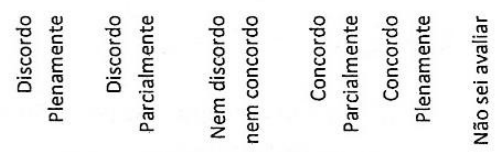

\section{Conteúdo}

a) A escolha do conjunto de conteúdos é adequada.

b) A sequência em que os conteúdos são apresentados favorece a progressão da aprendizagem.

c) O tratamento didático do conteúdo pode ser adaptado a alunos com diferentes estilos de aprendizagem.

d) O tratamento didático do conteúdo pode ser adaptado a alunos com diferentes níveis de conhecimento.

e) A apresentação do conteúdo é adequada com o nível de escolaridade proposto.

f) A abordagem dos conteúdos pode induzir algum tipo de erro.

g) O recurso está livre de erros conceituais.

\begin{tabular}{llllll}
\hline & 0 & 0 & 0 & 0 & 0
\end{tabular}

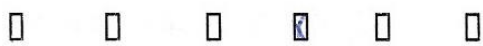
\begin{tabular}{lllll}
\hline & 0 & Q
\end{tabular} $\begin{array}{lllll}7 & 0 & 0 & 0 & 0\end{array}$ 


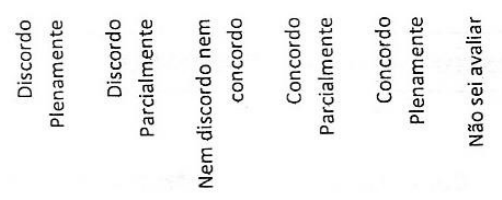

Linguagem e Orientações

a) A linguagem é apropriada.

b) As orientações e instruções oferecidas são claras, objetivas e suficientes.

\begin{tabular}{llllll}
\hline & $\square$ & $\square$ & $\square$
\end{tabular}

\begin{tabular}{llllll}
\hline & $\square$ & $\square$ & $\quad$ & $\square$ & $\square$
\end{tabular}

c) Apresenta material suplementar interessante.

\begin{tabular}{llllll}
\hline & $\square$ & $\square$ & $\square$ & $\square$
\end{tabular}

Interação

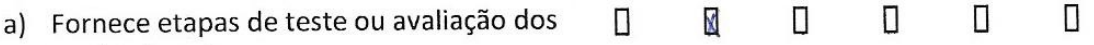
conhecimentos.

b) Permite avançar nas etapas ou níveis somente se o aluno dá a resposta esperada.

c) O tratamento dado ao erro pode promover a aprendizagem.

d) Auxilia para formular e testar hipóteses e
realizar comparações.

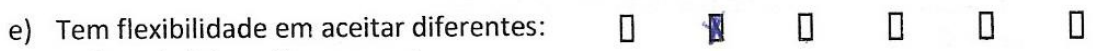
ordens de interações, respostas e estratégias.

f) O recurso possibilita que o aluno faça o $\quad$\begin{tabular}{llllll}
\hline & 7 & 0 & G
\end{tabular} registro e a consulta às ações realizadas.

g) Possibilita armazenar as respostas.

\begin{tabular}{llllll}
\hline & $\square$ & $\square$ & $\square$ & 日 & 口
\end{tabular} 
Navegação

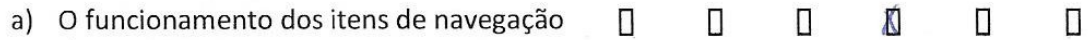
é adequado.

b) Existem rótulos, links, ícones e títulos $\quad \begin{array}{llllll}7 & 7 & 7 & \square & \square\end{array}$ que orientam a localização e facilitam a navegação.

c) Possibilita a adaptação da tela à leitura e $\quad$\begin{tabular}{llllll}
\hline & 0 & 0
\end{tabular} à navegação para diversas necessidades dos usuários.

3. Agora em termos gerais e pensando em qualquer recurso educacional aberto digital, por favor, indique seu grau de concordância com as afirmações a seguir?

Por favor, marque apenas uma alternativa em cada caso.

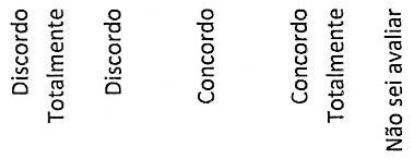

a) Podem oferecer uma contribuição significativa $\quad \begin{array}{lllll}7 & 0 & \text { G } & 0\end{array}$ e relevante à aprendizagem.

b) Exigem um apoio técnico adicional

$0 \quad 00$

c) Requerem uma atualização profissional para seu uso em sala de aula.

Sua opinião é muito importante para nós, por favor, escreva aquilo que ache pertinente em relação ao recurso apresentado ou as aos itens de avaliação consultados. 


\section{TERMO DE CONSENTIMENTO LIVRE E ESCLARECIDO}

Concordo em participar, como voluntário/a, da pesquisa intitulada: Uma análise crítica de recursos educacionais abertos digitais concebidos para o ensino-aprendizagem da Probabilidade e Estatística no Ensino Médio, que tem como pesquisador responsável Caio Cesar Santos Diniz, estudante do Instituto de Matemática e Estatística da Universidade de São Paulo, orientado/a por Viviana Giampaoli, os quais podem ser contatados pelo e-mail vivig@ime.usp.br ou telefone (11) 3091-6235. O presente trabalho tem por objetivos: a coleta de informações sobre a opinião de professores em relação ao uso de do recurso digital "Medidas do corpo: gráficos univariados" (http://m3.ime.unicamp.br/recursos/1233). Minha participação consistirá em preencher um questionário para avaliar este recurso. Compreendo que esse estudo possui finalidade de pesquisa, e que os dados obtidos serão divulgados seguindo as diretrizes éticas da pesquisa, assegurando, assim, minha privacidade. Sei que posso retirar meu consentimento quando eu quiser, e que não receberei nenhum pagamento por essa participação.

São Paulo, 24 de Outubro de 2015,

Nome

Assinatura 